741.95

.47

COPYI

\title{
The Brush of the Masters: Drawings from Iran and India
}

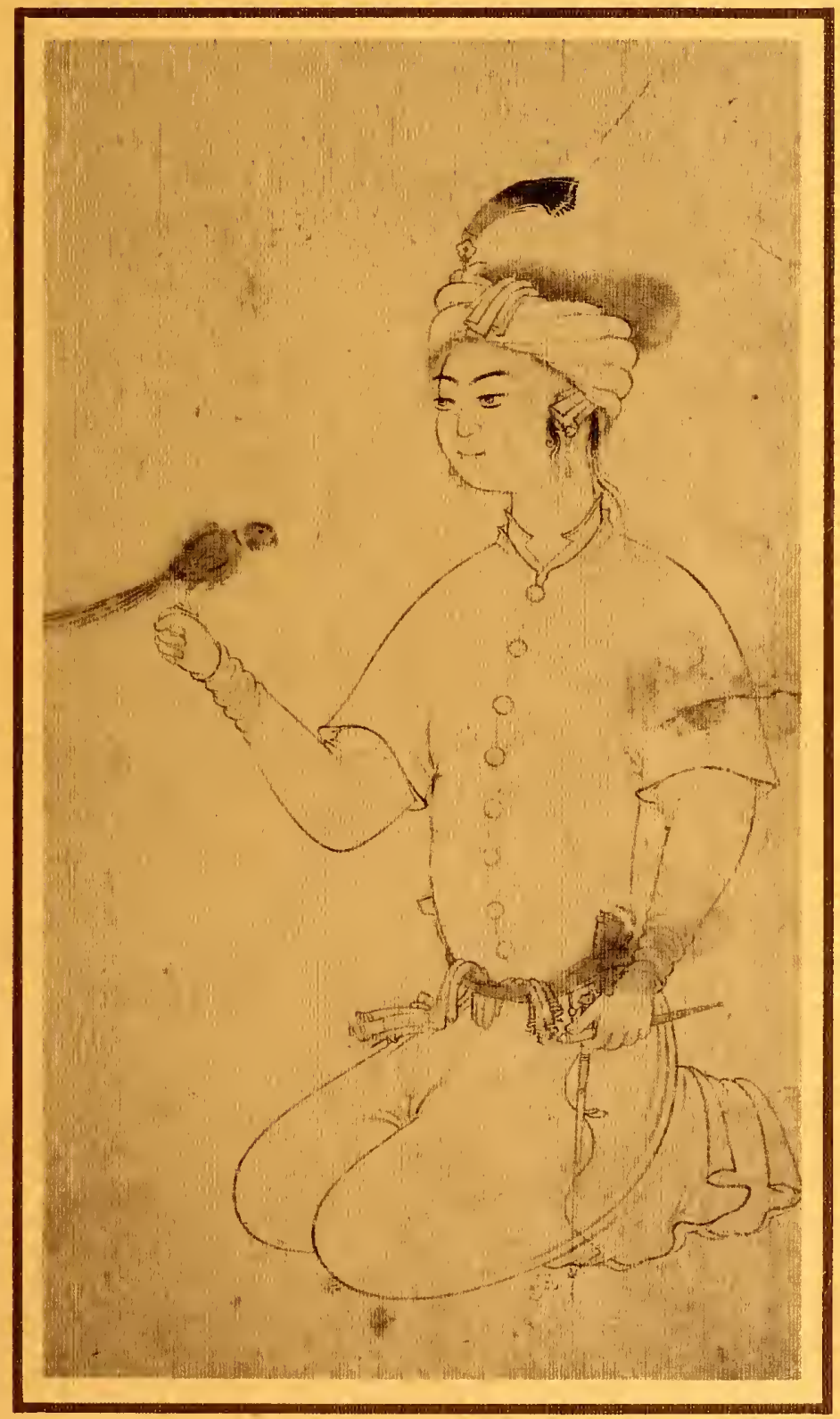

Esin Atil 


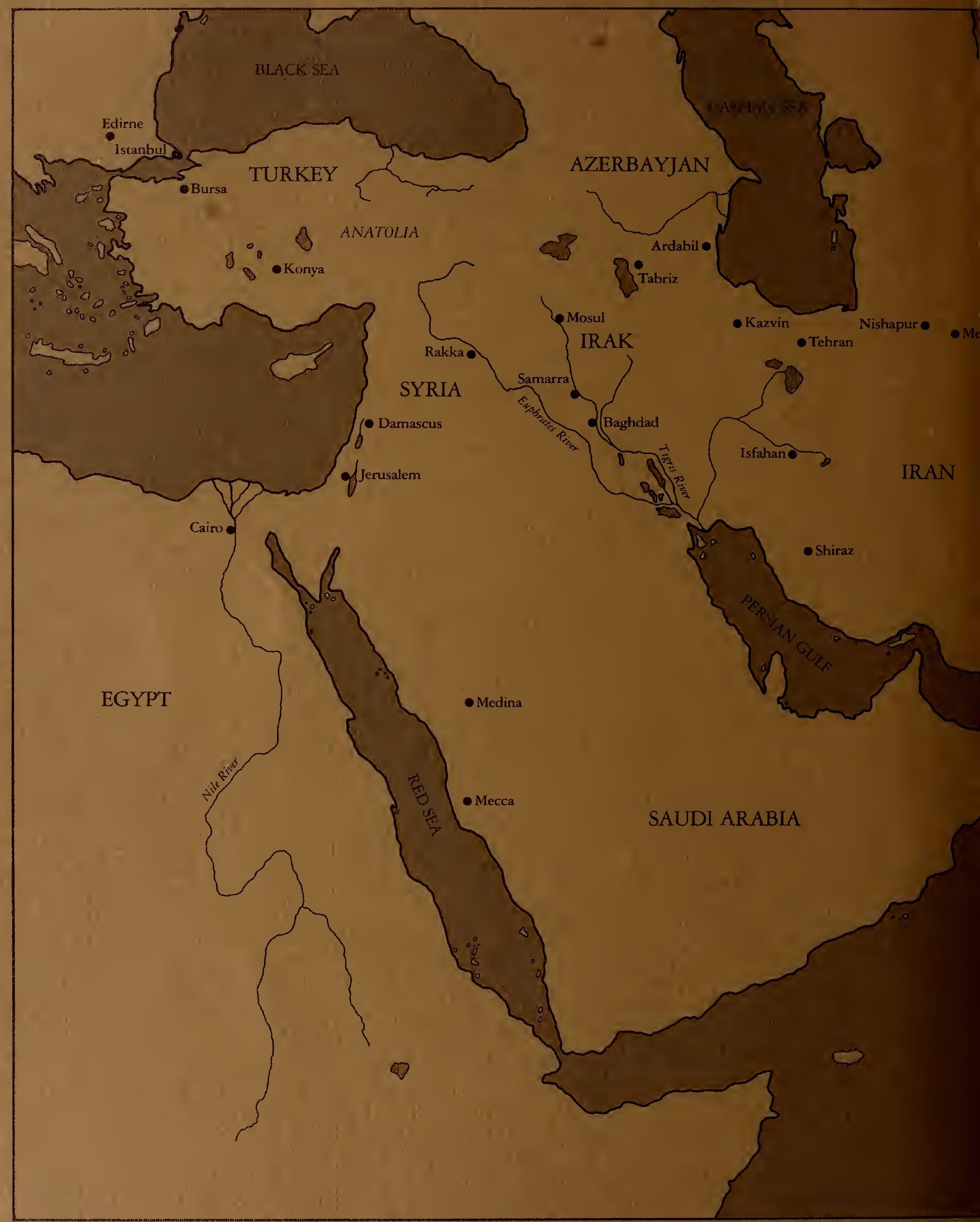




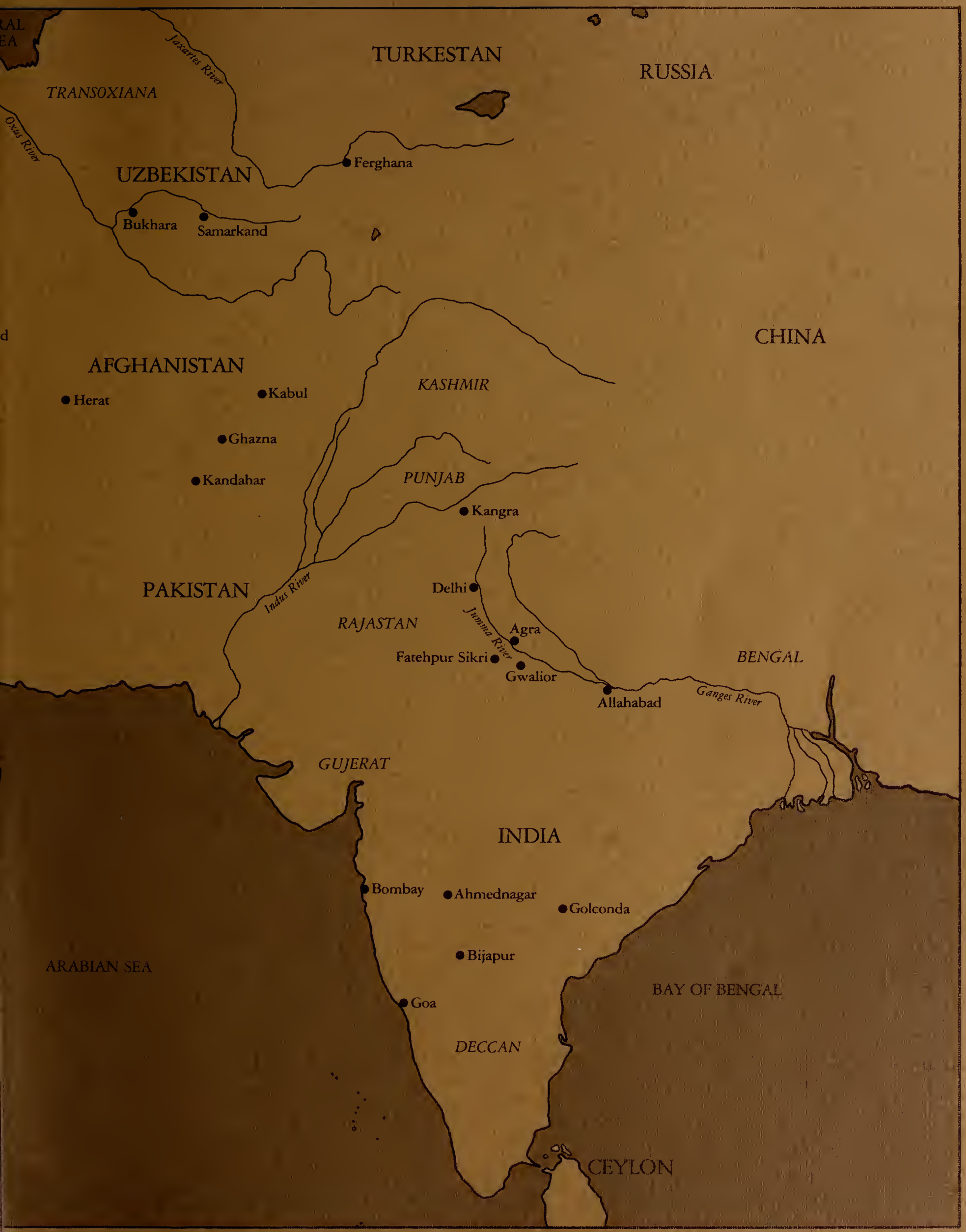





\title{
The Brush of the Masters: \\ Drawings from Iran and India
}

\author{
Esin Atil
}

Freer Gallery of Art

\section{THE FREER GALLERY OF ART}


Library of Congress Catalogue No. 78-70427

Copyright (C) Freer Gallery of Art, 1978

Design/Chaparos Productions Limited

Typesetting/Composition Systems Inc.

Printing/Stephenson, Incorporated

Production/Baker Johnson 


\section{Contents}

Foreword, 7

Drawings from Iran, 11

Jalairid, Timurid and Turkmen Schools, 12

Safavid Period, 32

Drawings from India, 97

Mughal School, 98

Deccani School, 126

Rajput School, 130

Notes, 143

Appendix, 147 



\section{Foreword}

Artists reveal themselves with disarming candor in their drawings. As faithful records of changes in forms and compositions or as notations of experiments with new imagery, drawings provide insights into an artist's creative processes that cannot be gained in any other way. Neither verbal descriptions nor written records of an artist's work can duplicate the immediacy of the information communicated directly by drawings. In Iran and India, where the names of all but the most famous artists are unknown, drawings are especially important since they offer tantalizing glimpses into those artistic techniques and traditions that were transmitted from generation to generation in imperial studios as well as in provincial workshops.

It is difficult to distinguish Iranian and Indian drawings from paintings, because the artists of those countries used the same materials and techniques for both. In some instances, as with the monochromatic decorative borders of illuminated manuscripts, it becomes all but impossible to make a distinction between the two media.

Since the majority of Iranian and Indian artists were involved in some way with the production of book illustrations, they excelled in the intimate scale of the miniature.

Their drawings constitute the initial statements for paintings that they knew would be studied with the same close attention as the written text. It is not surprising then that the drawings and the finished illustrations were also meant to be "read." Similarly, most of the texts were so familiar to the readers that the heroes, heroines, villains, warriors and deities depicted in the accompanying illustrations were immediately recognizable. For most readers, recognition of the various characters described in the text would be sufficient. Connoisseurs demanded more. Trained to differentiate between the styles of individual artists and schools, Iranian and Indian connoisseurs prided themselves on their ability to detect variations in established traditions or to identify any innovations an artist might introduce. Many innovations or exotic motifs were introduced in the decorative margins of illuminated pages where they would be relatively inconspicuous. Iranian and Indian artists were less inhibited in their drawings, and it is there that they were more apt to explore problems without regard to the strictures of prevailing canons or traditions.

With tradition playing an important role, it was inevitable that Iranian and Indian drawings and paintings should reflect perfection of technique. Yet, technique, in and of itself, was 
never considered sufficient reason for acclaim. It was an artist's ability to work within the narrow confines of carefully prescribed traditions, not the least of which was the juxtaposition of extraordinary realism and highly conventionalized motifs within the same composition, that occasionally elicited imperial patronage.

Among the Iranian and Indian drawings included in this exhibition are some examples that were acquired by Charles Lang Freer as early as 1907. Mr. Freer's interest in Indian and Iranian drawings at a time when most collectors still paid them scant attention, provides further indication of how enlightened a connoisseur he was. Mr. Freer continued to add to the drawings and paintings in his collection until his death in 1919. Thereafter, the curators of the Gallery were responsible for the growth of the Iranian and Indian collections. Many of the finest drawings included in this exhibition were acquired during the curatorship of Dr. Richard Ettinghausen from 1944 to 1967. Dr. Ettinghausen's discriminating taste and scholarly research were instrumental in raising the Freer Gallery's Iranian and Indian collections to their present position of international eminence. This special exhibition of Iranian and Indian drawings was proposed by Dr. Esin Atil, the current Curator of Near Eastern Art at the Gallery. She selected the drawings from the collections and prepared the text for the catalogue.

The drawings offer unusual glimpses into many different aspects of life in ancient Iran and India. The subjects range from the dazzling earthly paradises that typified court life, to religious mystics who appear to have been in a state of divine grace. As we study these drawings, we share the artist's reactions to people, to places and to events from a time that is irretrievably past. Because of the intrinsically spontaneous nature of drawings, these people, places and events come alive in a way that is more poignant than in the more hieratic world of miniature paintings.

Thomas Lawton

Director 
The Brush of the Masters:

Drawings from Iran and India 


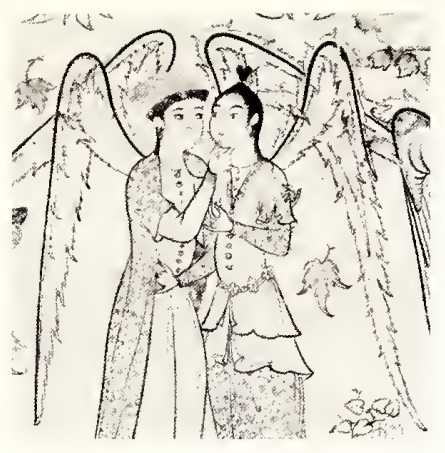

\section{Drawings from Iran}

The earliest drawings made in Iran are found in the marginal decorations of 15 th-century imperial manuscripts, as well as on single sheets which were later compiled into albums. The marginal decorations generally employ floral motifs and occasionally animals are placed within the landscape. The only exception to this scheme appears in a unique manuscript, the Divan of Sultan Ahmed, the Jalairid ruler whose courts were located in Baghdad and Tabriz. The marginal drawings of the Divan contain narrative scenes with figures participating in specific activities and are pictorial representations of the themes expressed in mystic poetry. Executed around 1400, these illustrations depict idyllic settings with nomadic figures, lovers and scholars and include an extraordinary scene with angels bearing celestial fire.

Single-page drawings bound in albums were made during the Turkmen and Timurid periods in diverse centers of the Near East and Central Asia and represent a variety of subjects, including courtly ladies and warriors. Among them is a remarkable group portraying demonic creatures which is associated with the shamanistic traditions of the pre-Islamic peoples of the Asian steppes.

Although these 15 th-century drawings were made by anonymous artists, each was executed by a single hand in contrast to contemporary manuscript illustrations, which often reveal the combined efforts of several court painters.

During the Safavid period the artists began to sign their works and the styles of individual painters became identifiable. Sixteenth-century drawings executed in the ateliers of Tabriz and Kazvin depict portraits of solitary figures as well as crowded compositions harmoniously blending a profusion of diverse elements. Studies of single men and women, representing elegant courtly youths in addition to elderly commoners, gradually became more dominant, commissioned by both the members of the court and wealthy citizens.

Patronage has always been an important factor in the development of the arts in the Islamic world, and the shift from imperial sponsorship to that of the middle classes is strikingly noticeable in the 17 th century. The artists began to assert their individuality, choose their own subjects and inscribe even the simplest sketch with statements that indicate when and where it was drawn. This highly personal approach characterizes the production of the school of Isfahan, the last Safavid capital, and points to the end of the long tradition of illustrated manuscripts as the individual works of famous artists became sought after by collectors. 


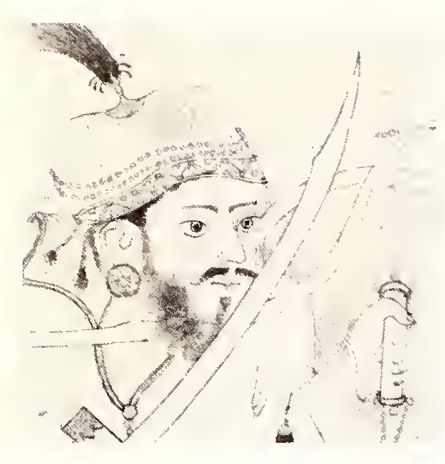

\section{Jalairid, Timurid and Turkmen Schools}

During the 15 th century, Iran was in constant political turmoil with a number of new dynasties rising to power and, shortly after establishing vibrant artistic centers, falling victim to the expansionist policies of the neighboring states. Cities such as Baghdad, Tabriz and Shiraz continually changed hands as the fortunes of a dynasty rose or fell. Yet the 15 th century was one of the most brilliant periods in Iranian art; each dynasty produced remarkable sultans who became enthusiastic patrons of the arts, supporting large studios and employing scores of calligraphers and painters.

As the political scene changed and the courts shifted the sites of their capitals, the artists migrated to the new centers and continued to create outstanding works of art. The traditions associated with one school soon merged with those introduced by the emigrés, forming a synthesis which in turn influenced the styles of other schools as the artists moved, or were forced to move, from one court to another.

The confusing political status of the artistic centers also affected the production of their studios. It is often difficult, if not impossible, to identify the provenance of a painting given the heterogeneous nature of the studios and the movement of the artists. Fortunately, there are a few signed and dated examples indicating where they were executed which enable us to more or less define the traditions of a particular school in a particular period.

In order to determine the influences exerted from one tradition to another, it is necessary to present a brief historical account of the major dynasties of the age and to review the status of the artistic centers.

Upon the disintegration of the Ilkhanids, the Mongol rulers of Iran, the Muzaffarids (1314-93) ruled southern Iran from Shiraz until their defeat by the armies of Timur. Another successor state to the Ilkhanids, the Jalairids (1336-1432), controlled western Iran and Irak, establishing courts in Baghdad and Tabriz. Baghdad was particularly creative under the patronage of Sultan Uvays and his son, Ahmed, during the second half of the 14th century. The city was captured twice by Timur who took a number of artists back to his court in Samarkand. The Jalairids were eventually overpowered by the Karakoyunlus, a federation of Turkmen tribes which had originally settled in eastern Anatolia.

The Timurids (1370-1506) ruled supreme in Samarkand, expanding westward from Transoxiana into Iran and Anatolia. Their periodic campaigns not only resulted in territorial gains 


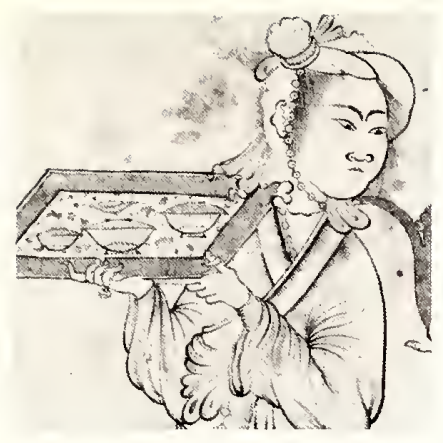

but also enriched the Samarkand studios, bringing back a booty of artists. After the death of Timur in 1405, cultural activities shifted to Shiraz and Herat. Herat was chosen as the capital by Shah Rukh, Timur's son, and the governorship of Shiraz was given to Sultan Iskandar, Timur's grandson. Shiraz, which had an active studio during the Muzaffarid period, became a major artistic center when Jalairid artists fled to Iskandar's court following the death of Sultan Ahmed. When Sultan Iskandar was called to Herat in 1414, he took members of his studio with him to the Timurid capital. The Timurid rule in Shiraz lasted until 1453, at which time the city fell to the Karakoyunlus.

Herat flourished under Shah Rukh and his son, Baysunghur. In the painting ateliers there were local artists, as well as those brought from Shiraz by Sultan Iskandar; others arrived in 1420 from Tabriz after a brief Timurid conquest of that city. Herat's greatest period was the last quarter of the 15th century, during the reign of Huseyin Baykara. After his death in 1506, the city was attacked by the Uzbeks and the Safavids who took some of the artists to their respective capitals in Bukhara and Tabriz.

The Karakoyunlu Turkmens (1389-1468) expanded eastward from Anatolia and spread throughout Iran, briefly capturing Herat in 1458. They chose Baghdad as their capital and established a provincial court in Shiraz. The painting studios of Baghdad and Shiraz flourished during the 1450 s and 1460 s under the patronage of Pir Budak, the son of the last Karakoyunlu sultan, Jahan Shah. In 1467 the Karakoyunlu Turkmens were defeated by another federation of Turkish tribes, the Akkoyunlu Turkmens, who rose to power from Anatolia.

Under the Akkoyunlu rule (1378-1508), Shiraz continued to be an important center until 1478 when the court moved to Tabriz. The Tabriz studios incorporated artists from Shiraz and Herat; Herat had been captured by the Akkoyunlus in 1469. The outstanding patron was Sultan Yakub, and his avid support of the Tabriz studios during the last quarter of the 15 th century resulted in the production of a large number of remarkable illustrated manuscripts. The Akkoyunlu empire was terminated in 1501 when Shah Ismail, the founder of the Safavid dynasty, defeated Sultan Ahvand and within a decade brought the whole of Iran under his control.

The most important group of 15 th-century drawings from Iran are in the Divan of Sultan Ahmed Jalair (nos. 1-7). ${ }^{1}$ There is also a series of single leaves, most of which were incorporated into albums (nos. 8-11). These albums include samples of calligraphy, single-page paintings, sketches, 


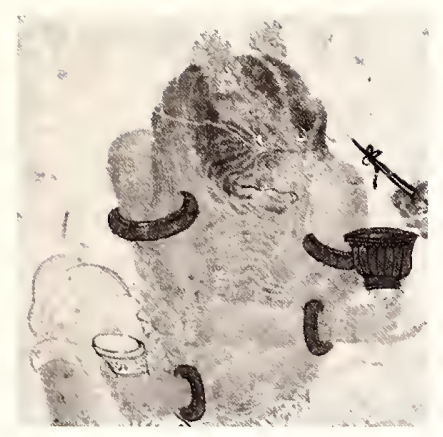

drawings and manuscript illustrations, as well as examples from European and Far Eastern traditions.

Two of the most famous collections, popularly called the "Fatih Albums" since they contain portraits of the Ottoman sultan, Mehmed II ("Fatih" or "the Conqueror"), appear to have been compiled by the Akkoyunlu sultan, Yakub. ${ }^{2}$ The paintings in these two albums date from the early years of the 14 th to the end of the 15 th century. Among them are a group of fascinating tinted drawings bearing the attribution "Mehmed Siyah Kalem," or Mehmed the "Black Pen," that is, one who works with brush and ink. ${ }^{3}$ These drawings depict either scenes of nomadic life or fantastic creatures (monsters or demons) engaged in various activities reflecting the shamanistic rites and traditions of Central Asia (no. 10).

The artistic milieu of Baghdad and Tabriz during Sultan Ahmed's reign was extraordinarily creative and innovative. The painters illustrated literary texts, such as the poems of Nizami and Khvaju Kirmani, which did not have earlier established prototypes. ${ }^{5}$ The sultan himself was an accomplished musician and poet, writing both in Arabic and Persian. He is said to have carved seals and knew how to paint; he was taught the art of painting by Abd al-Hayy, one of his court painters, and executed a drawing in a manuscript on Abu Said, the last Ilkhanid ruler.

Sultan Ahmed's strong interest in poetry and painting is exemplified in the Divan, a collection of his Persian poems. This extraordinary manuscript is the only copy of the work and contains the earliest marginal drawings which are conceived as complete compositions including human figures.

1-7. The Divan of Sultan Ahmed Jalair

Iran, Jalairid period, ca. 1400

Page: $29.2 \times 20.3 \mathrm{~cm}$ $\left(11 \frac{1}{2} \times 8\right.$ in $)$

Text $18.5 \times 11.5 \mathrm{~cm}$ $(71 / 4 \times 41 / 2$ in.)

337 folios, contemporary binding, illuminated heading (32.29); eight folios with marginal drawings (32.30-32.37)

\section{The Divan}

When Sultan Ahmed ibn Uvays (1382-1410), the last great ruler of the Jalairid dynasty, ascended the throne, he inherited a highly creative and energetic group of artists, including Shams al-Din, a former student of the celebrated Ahmed Musa. During his relatively long reign, Sultan Ahmed was under constant attack by the Kipchaks, Timurids and Karakoyunlu Turkmens. ${ }^{+}$The sultan was able to survive these defeats by escaping to the Ottoman or Mamluk courts and avoiding direct confrontation. He was killed in 1410 while fighting against Kara Yusuf of the Karakoyunlus in a final attempt to save his domain. Soon after his death, the Jalairid lands were divided between the Karakoyunlus and the Timurids.

In spite of the political turmoil of his reign, Sultan Ahmed managed to sponsor a series of outstanding illustrated 


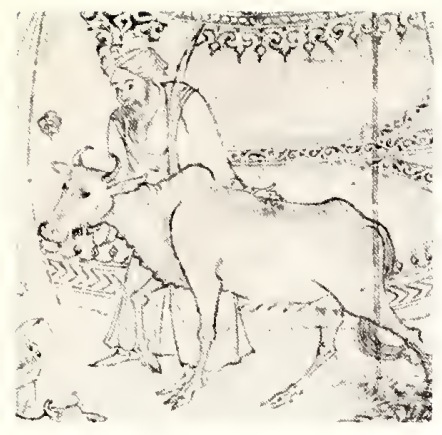

manuscripts and to support renowned artists. Among them were Junayd and Abd al-Hayy, the painters who had been trained by Shams al-Din, and the calligrapher Mir Ali of Tabriz, who is credited with the invention of the nastalik. script. The artists of Sultan Ahmed's court were so highly regarded that Timur took a group of them to Samarkand when he conquered Baghdad. Following the death of Sultan Ahmed, a number of painters joined the court of Sultan Iskandar, the Timurid governor of Shiraz. Several masters appear to have remained in Baghdad and Tabriz, seeking employment under the new rulers, the Karakoyunlus. The stylistic features determined by the Jalairid artists of the court of Sultan Ahmed were influential in the development of Timurid and Turkmen schools of painting.

The manuscript contains 337 folios written in a fine nastalik script; eight of the folios have marginal drawings rendered in black ink with slight touches of blue and gold (fols. 17a, 18a, 19a, 21b, 22b, 23a, 24a and 25b). ${ }^{6}$ The work was rebound at a later date but the original cover was retained during the restoration. Presently, the binding has a modern spine and lacks the traditional flap attached to the back cover. The bookbinding is a brown leather on pasteboard with stamped and tooled decoration and contains traces of gilding. The central ogival medallion and corner quadrants decorating the exterior of the front cover are filled with arabesques, enclosed by several braided and interlacing bands. Although the layout of the exterior of the back cover is identical, the central medallion depicts a landscape with a deer and doe; a crouching hare appears amidst foliage in each of the corner quadrants. The enclosing bands are also varied, using floral scrolls as well as braiding. The interiors of both covers are enhanced with reddish-brown leather; filigree work, embellished with gold cartouches and placed over a blue ground, decorates the central medallion and corner quadrants.

The work begins with an illuminated heading (fol. lb) and contains the poems of Sultan Ahmed who practiced different forms, such as the matbnavi (couplet), kasida (monorhythmic poem), ghazal (ode), rubai (quatrain) and kita (fragment). Gold and blue lines are used around the text leaving wide margins; there is an additional border of blue and red lines, and on the folios with marginal illustrations, they are drawn over the scenes. Gold lines separate the poems and divide the hemistichs. The poet's name is also rendered in gold and appears as "Ahmed," "Ahmed Uvays" or "Ibn Uvays"; in the ghazals, the name is always in the last line in accordance with Iranian practice. 
Each poem begins with the following phrase: "and by him too, may God Almighty make his caliphate and sultanate abide forever," executed in gold, blue or red; occasionally only the word "caliphate" is used, or the order is reversed to read "sultanate and caliphate."

The works of Sadi have been added to the wide margins of the text, beginning on folio $2 \mathrm{a}$ and ending on folio $31 \mathrm{la}$ where the date of this later addition is given as 1643 . The red and blue lines around the margins also belong to this date and terminate on folio $31 \mathrm{la}$. The remaining 26 folios have blank margins. There are also several blank, or almost blank, folios toward the end of the manuscript.

The text lacks a colophon, but on the last page (fol. 337b) there are two notations, executed by different hands, which give information on the date of the manuscript and its copyist. The notation on the very top of the folio states: "the book was finished with the help of God, the Giver, in the month of Ramazan, in the year eight and five hundred in Hijra of the Prophet, God bless him." The date "eight and five hundred," or 508 Hijra, corresponds to 1114 A.D.; however, if it was intended to be $805 \mathrm{Hijra}$, then the year 1402 A.D. is given, which falls within the reign of Sultan Ahmed. The month of Ramazan, 805 Hijra, corresponds to March-April, 1402 A.D.

The second notation, written on an angle on the lower portion of the folio, reads: "the handwriting of Mir Ali, mercy be upon him." It refers to the famous Mir Ali of Tabriz who worked in the court of Sultan Ahmed and copied the poems of Khvaju Kirmani for the sultan. ${ }^{7}$ Since this work and the Freer Divan reveal the same style of writing, there is no reason to doubt the validity of the attribution.

The flyleaf at the beginning of the manuscript and the last folio of the text possess several seals. Only the one on the last folio is clear enough to decipher: it is an Ottoman tugra (royal seal), identified as that of Sultan Beyazid II (1481-1512), which indicates that this volume once belonged to the imperial collections of the Topkapi Palace in Istanbul.

Very little is known about the history of the work prior to the 20th century; in 1912 it was purchased in Istanbul by F. R. Martin, and in 1932 it entered the collection of the Freer Gallery of Art. The reconstruction of the early history of the Divan is purely conjectural: it may have passed into the hands of the Karakoyunlu Turkmens after they defeated and killed Sultan Ahmed, then to the Akkoyunlus who put an end to the Karakoyunlus in 1467. Since the work contains the tugra of Sultan Beyazid II, it could have been presented to him by 


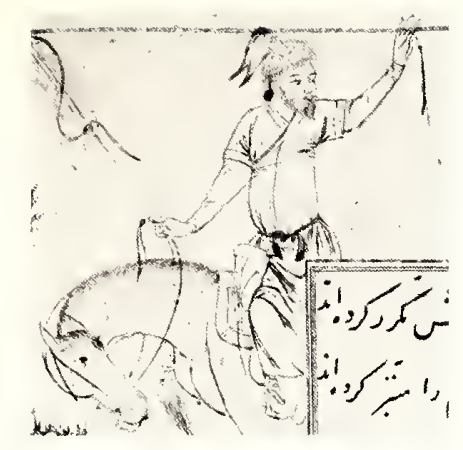

the last Akkoyunlu sultan, Ahvand, who fled to the Ottoman court after his defeat by Shah Ismail in 1501. The Divan remained in the Ottoman Palace, or at least in Istanbul, until it was obtained by Martin in the early years of the 20th century.

The eight marginal drawings, executed in fine brushwork, are conceived as complete scenes filling the entire surface of the folios. Although positioned around the text, the scenes appear as if the poems are placed over them, harmoniously extending under and around the text. Similar to the other examples of manuscript illustration executed in the court of Sultan Ahmed, the drawings reveal a new concept in painting: small figures are placed within a landscape setting which extends high into the horizon; a multitude of elements are integrated into the scenes, creating rich but spacious compositions. These features, determined by the Jalairid painters, were fully developed in the Turkmen and Timurid courts.

The lyric quality of the drawings parallels the themes of the poems which are mystical in nature, exhalting love and praising the Creator. The drawings are not "illustrations" of the text but pictorial representations of the sentiments expressed by the poet. In a recent publication by Deborah Klimburg-Salter, they have been interpreted as depicting scenes from the Mantik al-Tayr (Conversation of Birds) by Attar in which 30 birds (symbols of mankind) undertake a spiritual journey in search of God, passing through seven stages or valleys. In this study, the artist has been identified as Abd al-Hayy who worked in the studio of Sultan Ahmed in Baghdad and was a master in the art of drawing. ${ }^{8}$

The placement of the drawings within the manuscript is rather curious; they are clustered together between folios 17 and 25. It is possible that the entire Divan was meant to be adorned with marginal drawings since the folios have exceptionally wide margins. The artist may have executed a small portion, almost one signature, before the manuscript was collated and bound.

There is also no logical explanation for the six empty folios toward the end of the book. ${ }^{9}$ The suggestion that they were left blank for illustrations seems unlikely; the placement of the paintings in these locations would have been most untraditional for Islamic manuscripts. Perhaps additional poems were to be included and the author was still engaged in refining them while the calligrapher copied the finished ones. The work on the manuscript must have been interrupted by the political disorders of the age, most likely by the 1401 sack of Baghdad by Timur. 


\section{Pastoral Scene}

Black line on puper $32.30($ fol. 17a)

The drawing depicts a country scene with a flock of geese flying over the landscape. On the left, an old man leaning on a staff accompanies a woman carrying a child. Below them are a pair of water buffaloes and a body of water with several ducks. On the lower right, two more buffaloes approach the water; a young man, riding one of the animals, holds their reins and guides them with a stick.

The scene is executed in fine brushwork with varied intensity of pigment. Certain elementssuch as the outlines of the hills, clusters of bushes and blades of grass - are defined in darker strokes while washes and softer tones are used in modeling the landscape and figures. A feeling of depth is created by the suggestion of receding planes, moving from the water in the foreground to the hills placed high on the horizon.

The vignette of a young man guiding buffaloes resembles the theme employed in Far Eastern painting. Cultural exchanges between Iran and Central Asia had been established during the $11-$ khanid period, and a number of Far Eastern features are frequently encountered in 14 th- and 15 thcentury paintings.

The scene has been interpreted by Deborah Klimburg-Salter as representing the Valley of the Quest from Attar's Mantik al-Tayr. It symbolizes the first stage in the spiritual journey in search of God.

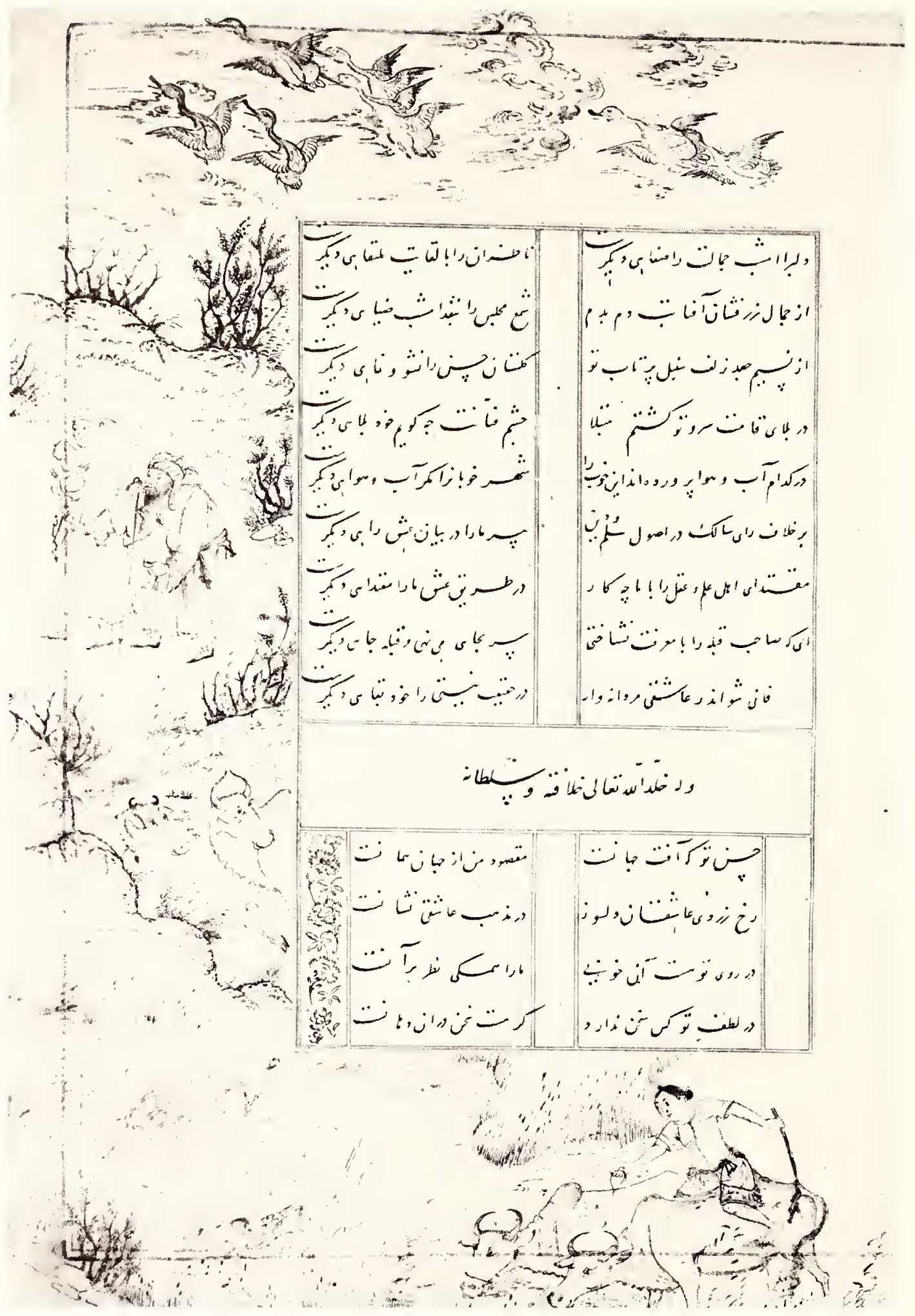



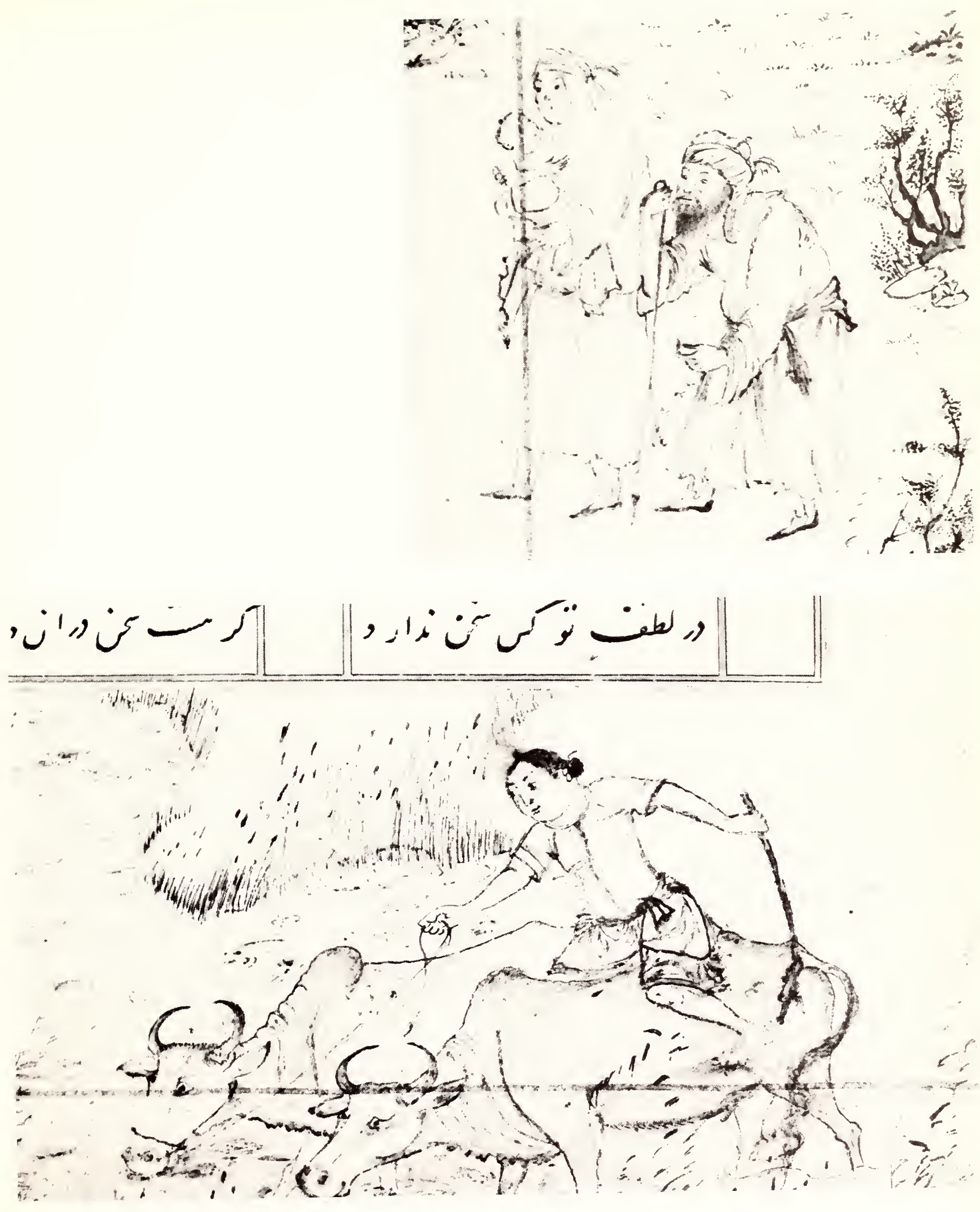


\section{Landscape with Two Couples}

Black line on paper 32.31 (fol. 18a)

A plane tree in full bloom with birds fluttering about its branches extends around and under the text. On the left, a youth leaning against a barren tree converses with a young woman. Below them is a tray with two bottles of wine, an incense burner and a bowl of fruit next to an empty bed covered with carpets and cushions. On the lower right, another woman reclines against a cushion while a second man, lost in thought, sits behind the trunk of a tree.

Similar to the previous example, this scene is executed in varying tones of black pigment with no additional color. The empty and disorderly bed, together with fruit and wine, suggest that it was recently used by the couples. The theme is identified as the symbolic representation of the Valley of Love, the second state in Attar's mystical poem.

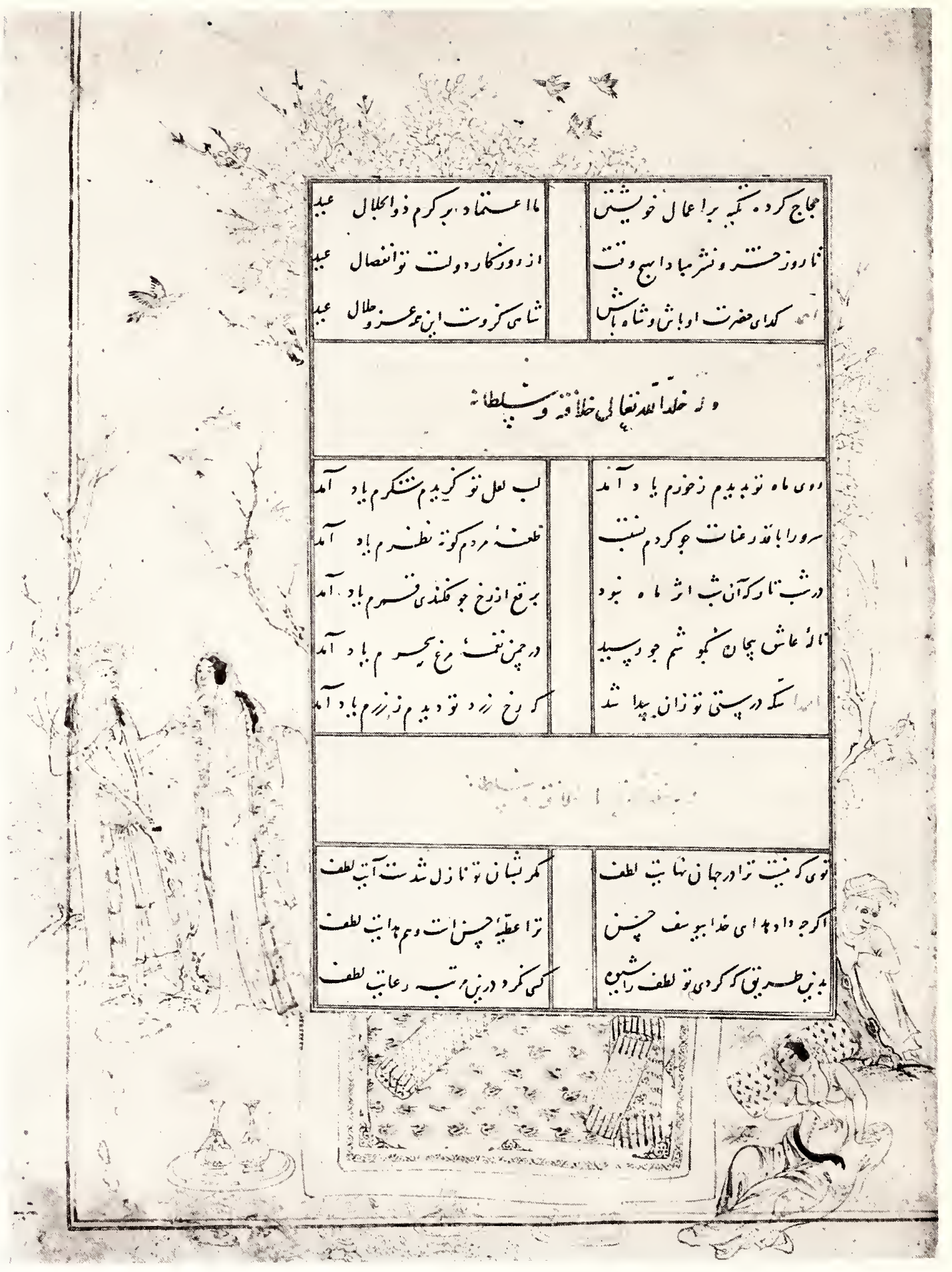



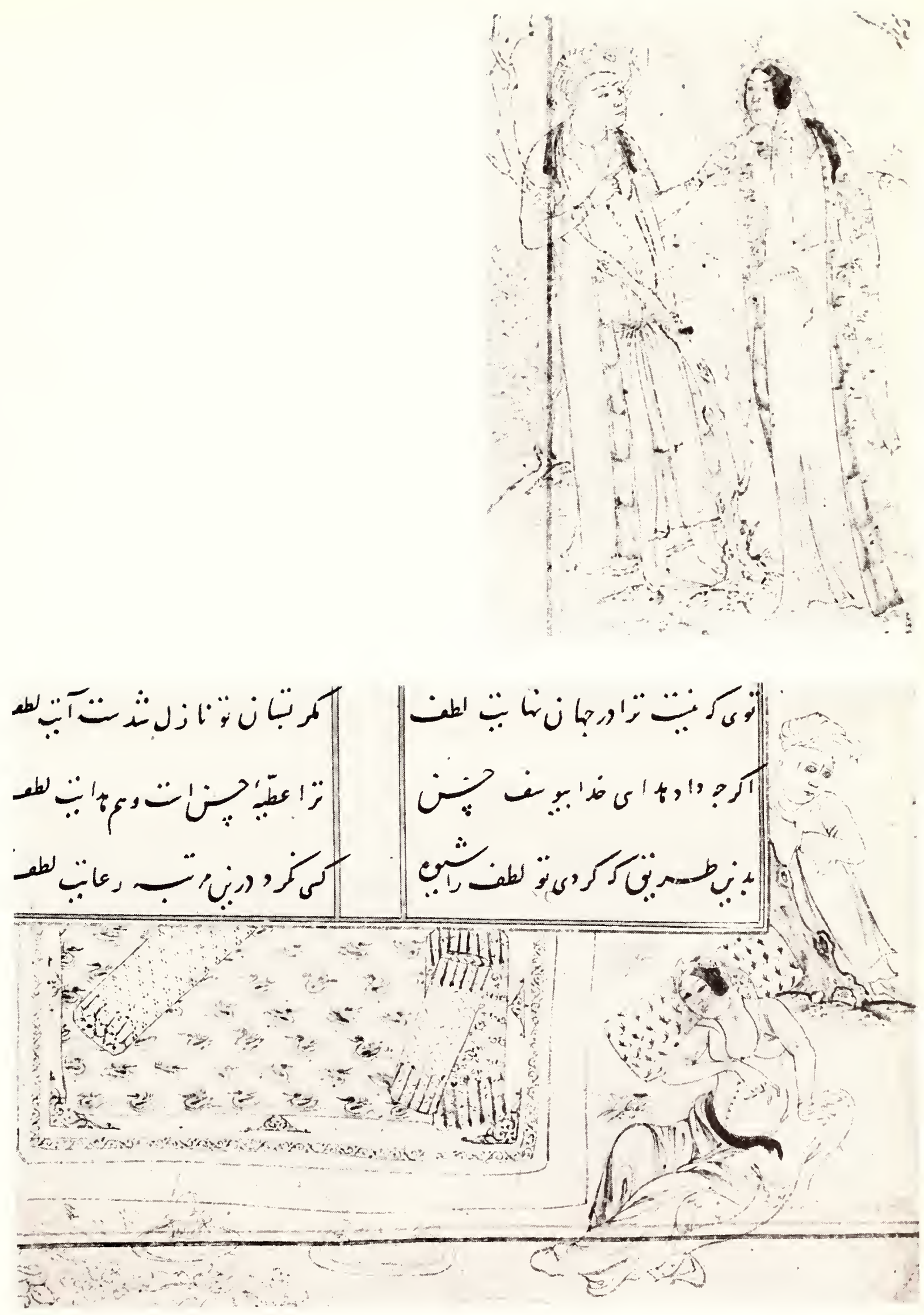
3. Gathering of Scholars

Black line on paper

32.32 (fol 19a)

Similar to the previous drawing, a fully foliated plane tree teeming with birds grows around and under the text. On the lower left, a pair of bearded figures hold a discussion while seated on a carpet with several books piled in front Below them, three men listen to a couple of personages who hold addicional books. On the lower right, next to the tree trunk, is a terrace with a carved balustrade and a bunch of flowers growing from its upper edge.

Scholars and sages holding discussions under a plane tree are commonly seen in the illustrations of contemporary literary texts. This scene is thought to depict the Valley of Understanding in which knowledge is sought.

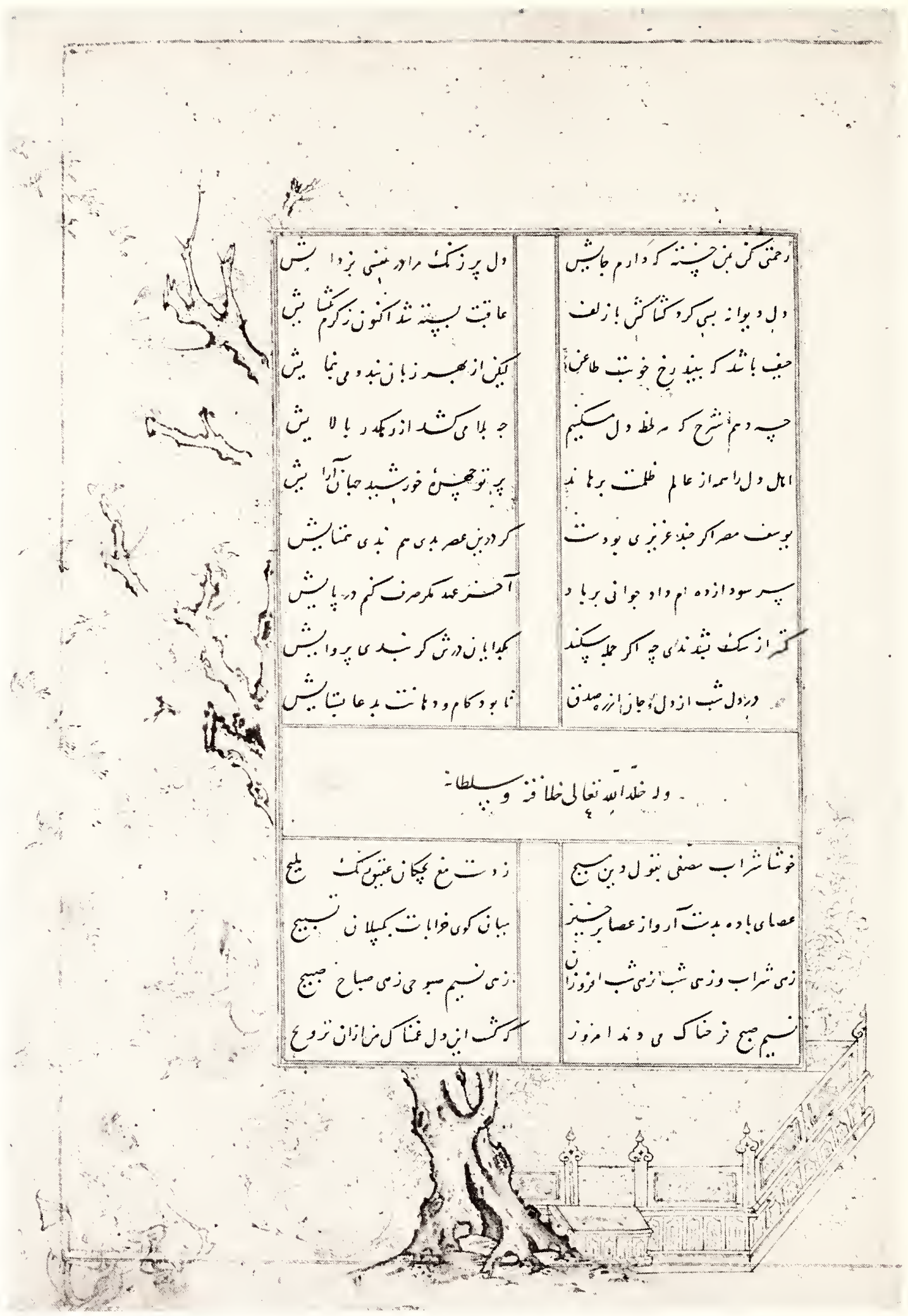




\section{Angels Amidst Clouds}

Black line and gold on paper; tinted with red and blue 32.33 (fol. 21b)

A stream of golden clouds flows down the right margin of the folio, filling the lower portion. Three angels peer from the opening of the sky on the top while 12 others ride down with the clouds. Two figures on the lower portion carry flaming torches or incense burners.

The sky, wings of the angels and some of their garments are rendered in blue; a brownish red is used on several other garments. The extensive use of gold in the clouds, bursting through the folio, is quite remarkable and possibly represents the Divine Light.

The theme represented here is the Valley of Astonishment in which neither man nor beast dwells. This valley is the sixth stage in Attar's work and appears out of sequence in the Divan. Six lines of text in the upper left margin and the catchwords below belong to the 17 th-century addition of the works of Sadi.

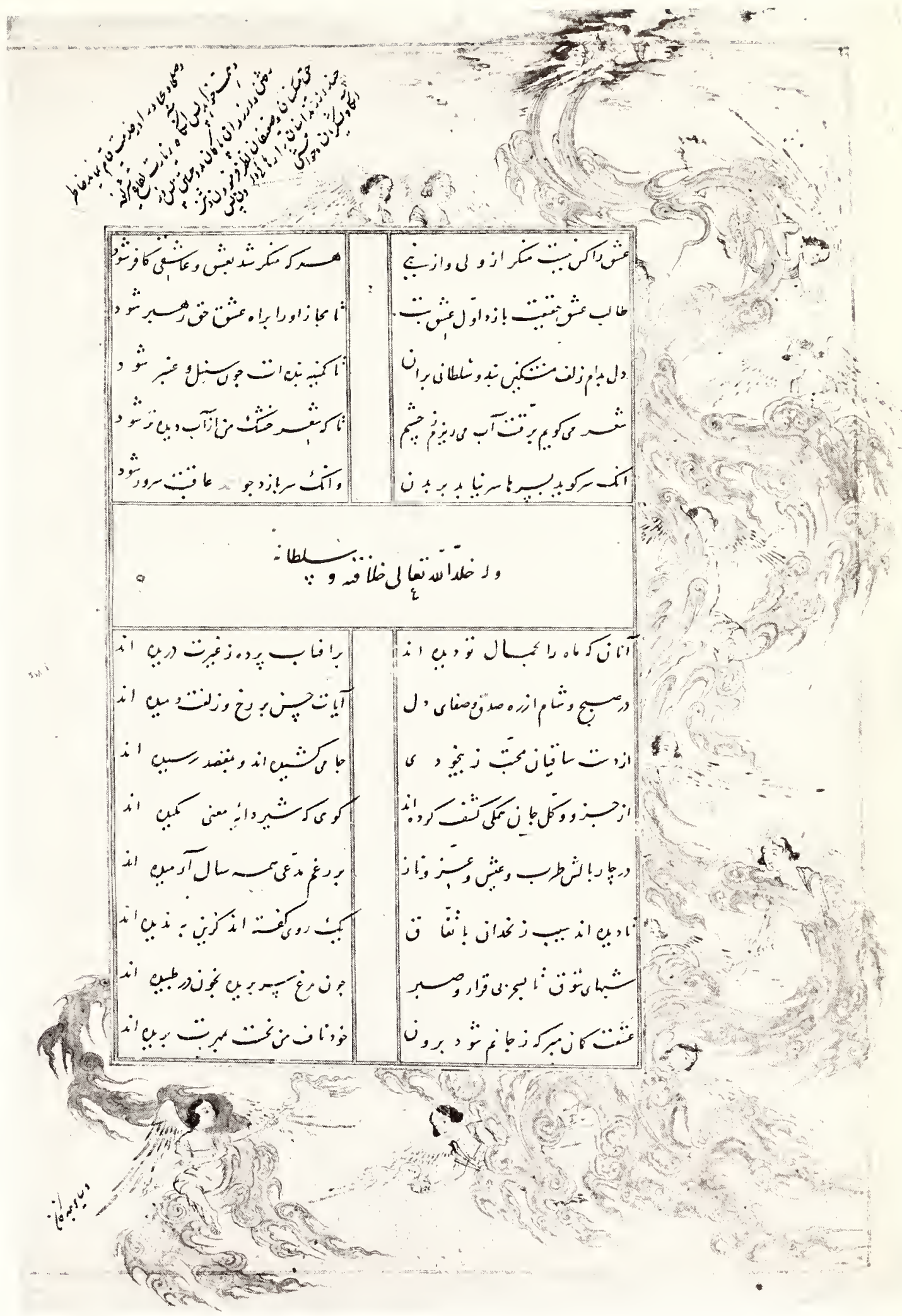




\section{5.-6. Camp Scene}

Black line on paper; tinted with red and blue

$32.34-32.35$ (fols 22b-23a)

This pair of drawings, representing the activities of a nomad camp, is the only scene in the Divan which spreads to double folios. The right portion depicts the actual camp whereas the left describes the surroundings. On the upper right are four tents with their convertible hoods partially or completely open for ventilation; smoke from one of the tents escapes through the opening.

Strolling around the structures are a pair of women and a bearded man guiding his cow. Below him, an elderly woman tends the herd.

On the lower right, a couple is busy setting up their tent, attaching the convertible hood and tightening the girdle around the structure. Seated next to them is a young mother holding her infant while a pair of children play in front. On the lower left, a woman blows the fire lit under a large kettle whereas her companion washes clothes at the edge of a river; behind them are several dogs tied by a leash.

On the lower portion of the facing folio, a pair of figures bring more firewood. The margin on the far left depicts the animals of the nomads: long-haired sheep or goats with large horns run about while several horses graze or rest. A horseman on the upper left holds a long whip and waves at his friends; next to him, a woman converses with another man who is riding a cow. The margins between the two folios are handled as a unit: on the right an elderly man holding a stick and a woman carrying a bowl walk toward the man who stands on the facing page, next to his flock.

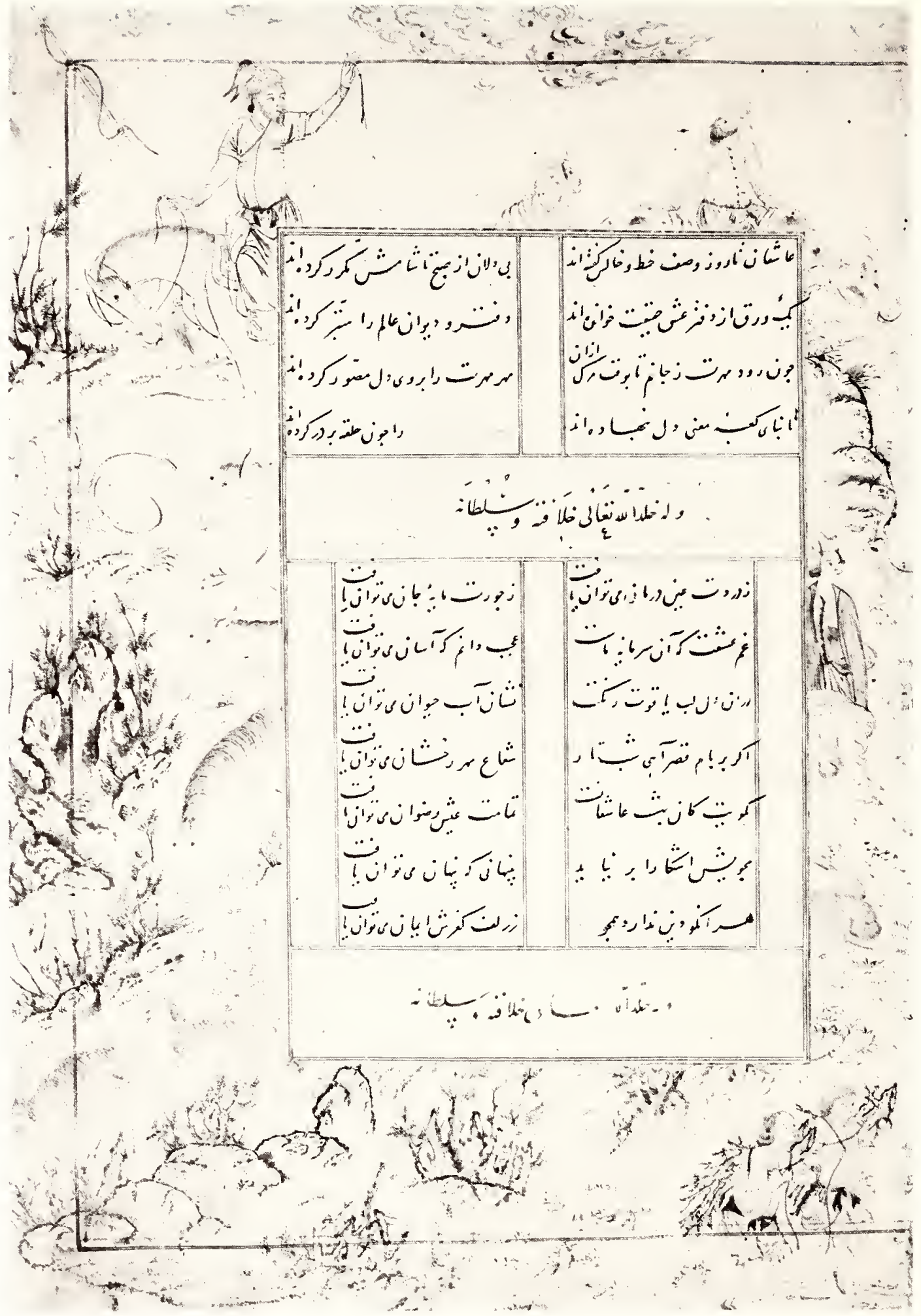




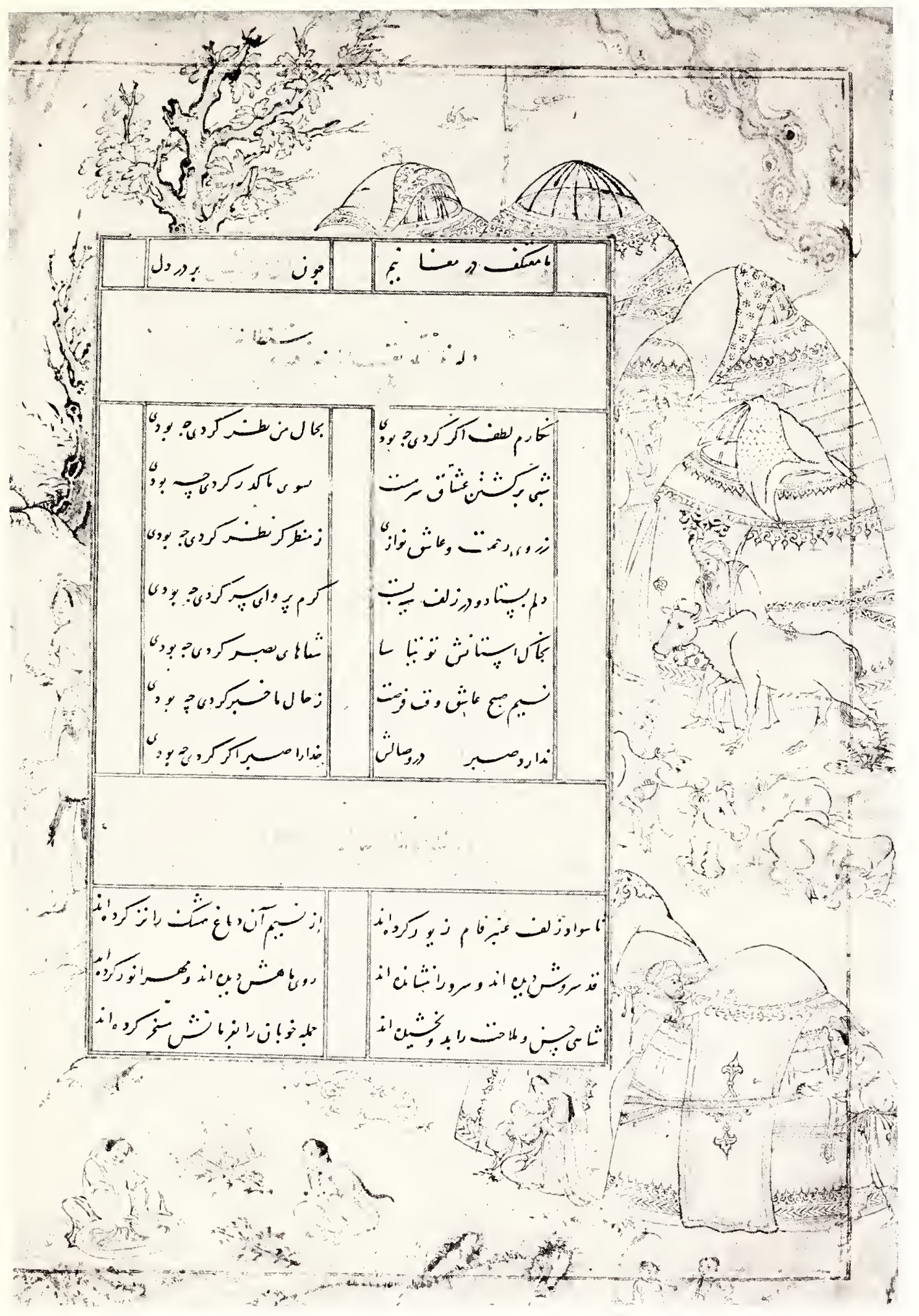

Touches of blue appear in the grass growing on the banks of the river in the foreground and clusteed around the tree as well as in the clouds, plants and foliage filling the left page. The fine red lines seen on the garment and headdress of the horseman holding the whip and on one of the tents seem to be later additions.

These folios depict the setting of a nomad camp, its activities and inhabitants in great detail and accuracy. The artist has clearly represented the construction of the tents and their decoration; the men, women and children of the tribe and their function within the system; the domesticated sheep, goats and cattle, plus the horses and dogs which are essentrial to the existence of the group. Although a multitude of elements and vignettes fill the margins, the scene is not overcrowded. It represent the utopian harmony of man and nature as expressed in Attar's Valley of Detachment, the fourth stage in the journey of the birds.

25 


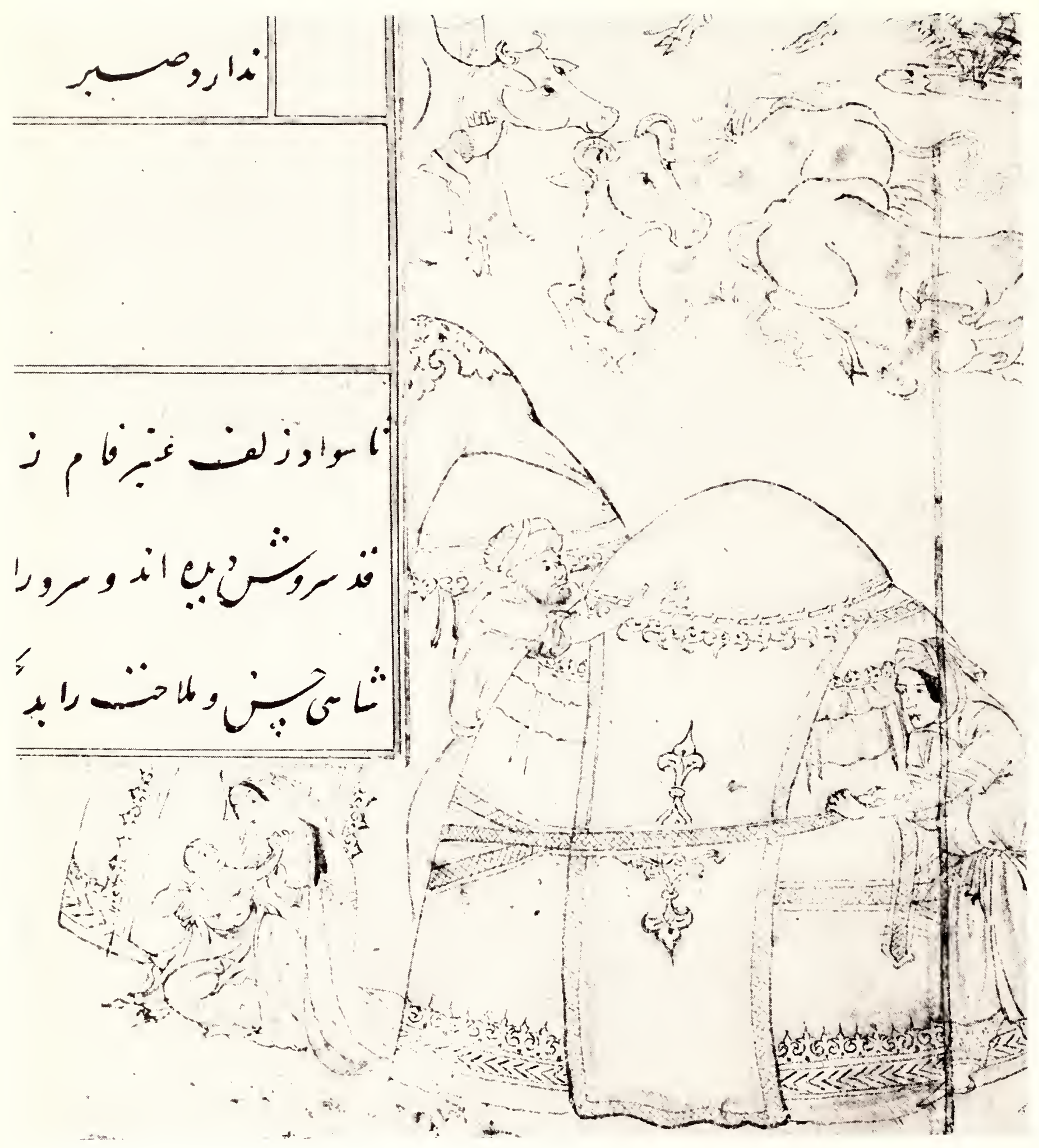




\section{River Scene}

Black line on paper

32.37 (fol. 25b)

This scene is devoid of human representation and depicts a landscape with birds flying over a winding river in which a pair of ducks swim. On the upper portion, cranes and geese fly through swirling clouds, while on the right, several other species of birds and butterflies hover around the trees and shrubs growing at the edge of the river. The river swings down the margin and flows into the lower portion. A tree and pair of birds appear on the left margin.

The harmonious juxtaposition of the elements suggests the fifth stage in Attar's work which describes the Valley of Unity where all forces of nature follow a single rhythm.

The remaining illustration from the Divan (32.36, fol 24a) originally depicted a river scene with several ducks, and could have represented the seventh and last stage in the Mantik al-Tayr, the Valley of Nothingness, beyond which one can go no further. The margins of this folio are now completely covered with the works of Sadi which almost camouflage the delicate drawing. Two female figures were added to the small squares on either side of the last couplet in the text.

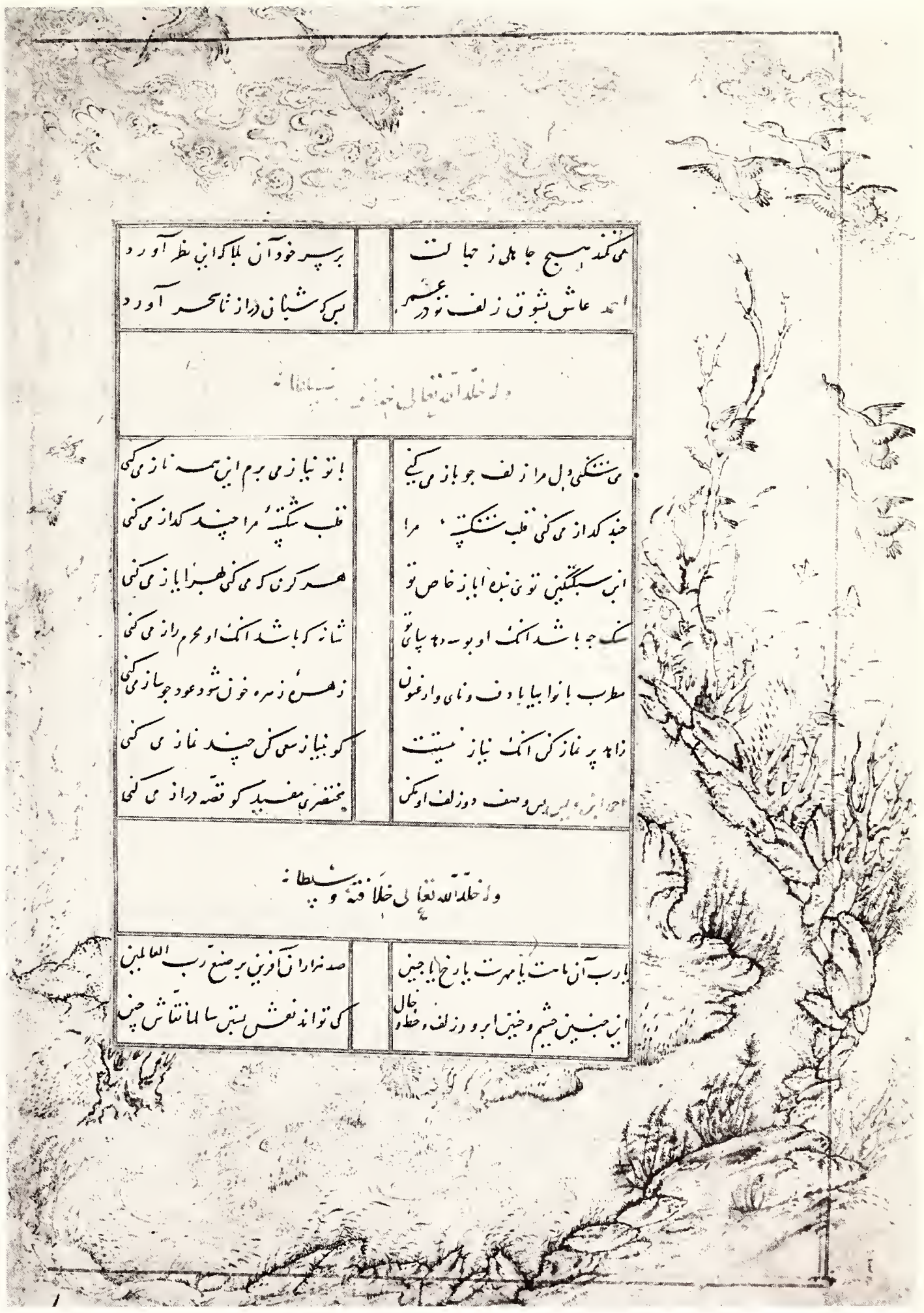




\section{Warrior}

Iran or Central Asia, Turkmen or Timurid period, 15th century

Black line and gold on paper; tinted with red and pink

Page: $38.7 \times 23 \mathrm{~cm}$.

(151/4 $\times 91 / 16$ in.)

Drawing: $24.3 \times 13.5 \mathrm{~cm}$

$\left(9^{9} / 16 \times 5 \%\right.$ in. $)$

29.79

This drawing, removed from an album, is enclosed by several borders and pasted on a deep-blue sheet decorated with gold floral motifs. The page has been backed with a blank piece of cardboard.

The figure represents a Mongol or Tatar warrior, attired in a helmet, belted tunic, short pants and low-heeled shoes. He is fully equipped with the weapons of his profession: he holds a shield and sword and carries a bow around his neck while a hatchet hangs over his arm; tucked into his belt are a dagger and the scabbard of the sword. The figure appears to be running to the left, one foot firmly planted on the ground whereas the other is lifted.

The face, hands and bare legs are tinted pink; red dots decorate his helmet and the scabbard; gold is used in the metal parts of his weapons and garments, as well as on his helmet, collar, sash and shoes. He wears a large earring and gold beads adorn his headdress

There exists an identical drawing executed in the Ottoman court during the 17 th century. ${ }^{10}$ The Turkish figure is the same size, indicating that it was traced or copied from the Freer drawing, which must have been formerly a part of the Istanbul albums.

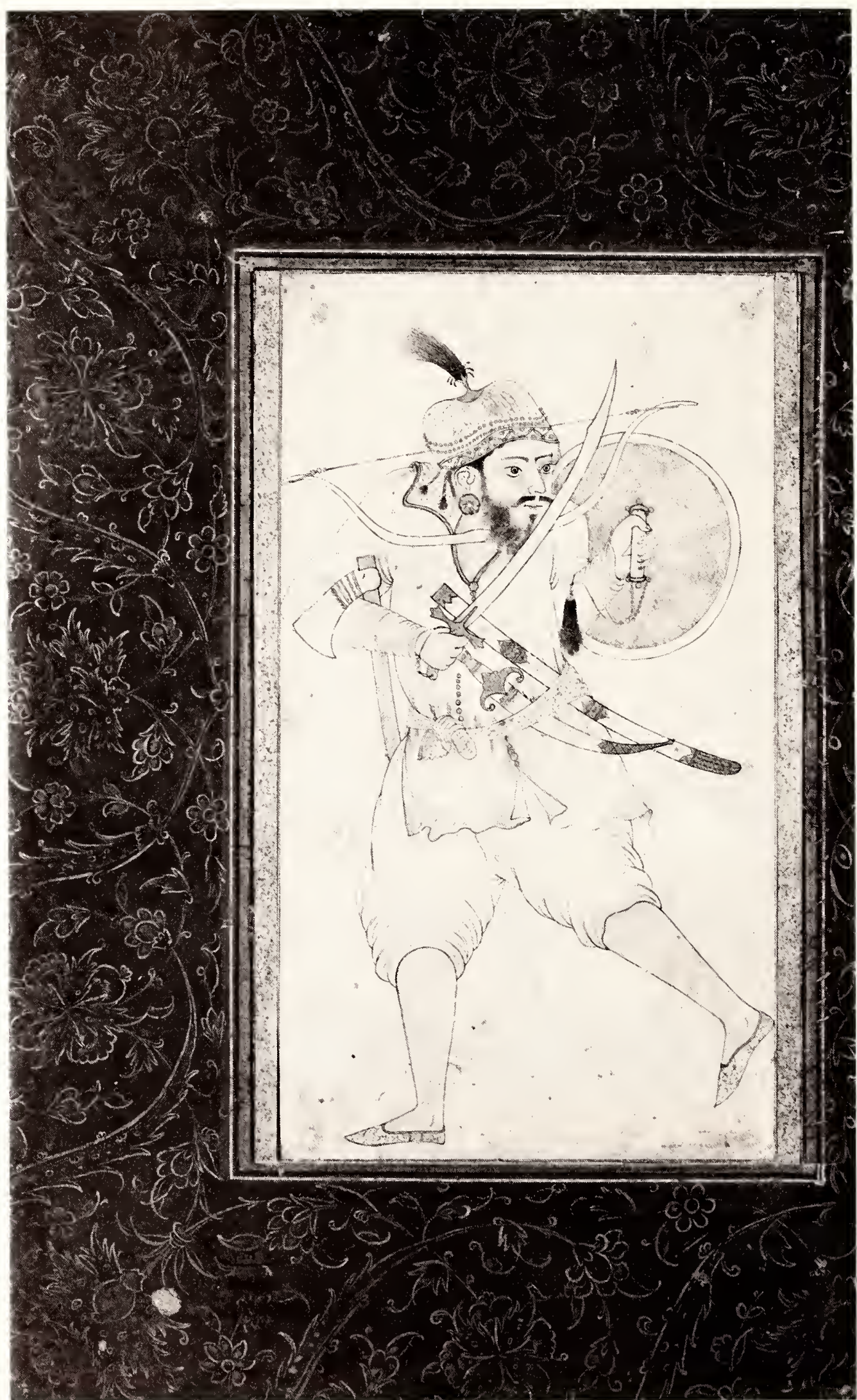


9. Women with Tea Service

Iran or Central Asia, Turkmen or

Timurid period, 15 th century

Black line and gold on paper; tinted with red, blue and green Page: $40.4 \times 28 \mathrm{~cm}$. $157 / 8 \times 11$ in.)

Drawing: $19.6 \times 15.9 \mathrm{~cm}$ $(73 / 4 \times 61 / 4$ in. $)$

38.14

The drawing, enclosed by several borders, is pasted on an album leaf which has wide margins decorated with gold floral designs on a beige ground. Two samples of calligraphy appear on the back.

The woman on the left carries a tray with several covered bowls while her companion holds a strange-looking teapot. Both woman have elaborate headdresses; pearls, ribbons, streamers and tassels adorn their hair. They are dressed in loosely belted jackets and long skirts, wear hobnailed shoes and bear archer's rings on their thumbs. Their facial features suggest that they are of Central Asian or Far Eastern origin.

The representation of their garments with highly decorative folds and drapery, peculiar hairstyles and confusing tea equipage indicate that the drawing was executed by an artist remotely familiar with Asian women and depicted what he thought they looked like.

Gold is used exclusively on the teapot, on the lids of the tea bowls and in the long dangling earrings (?) of the lady on the right. Touches of pale red, blue and green appear on the garments, hair ornaments and tray.

This drawing may have been executed in Samarkand during the Timurid period or in Tabriz under the patronage of the Akkoyunlu Turkmens. A number of similar examples appear in the Istanbul albums where this piece might have originated.

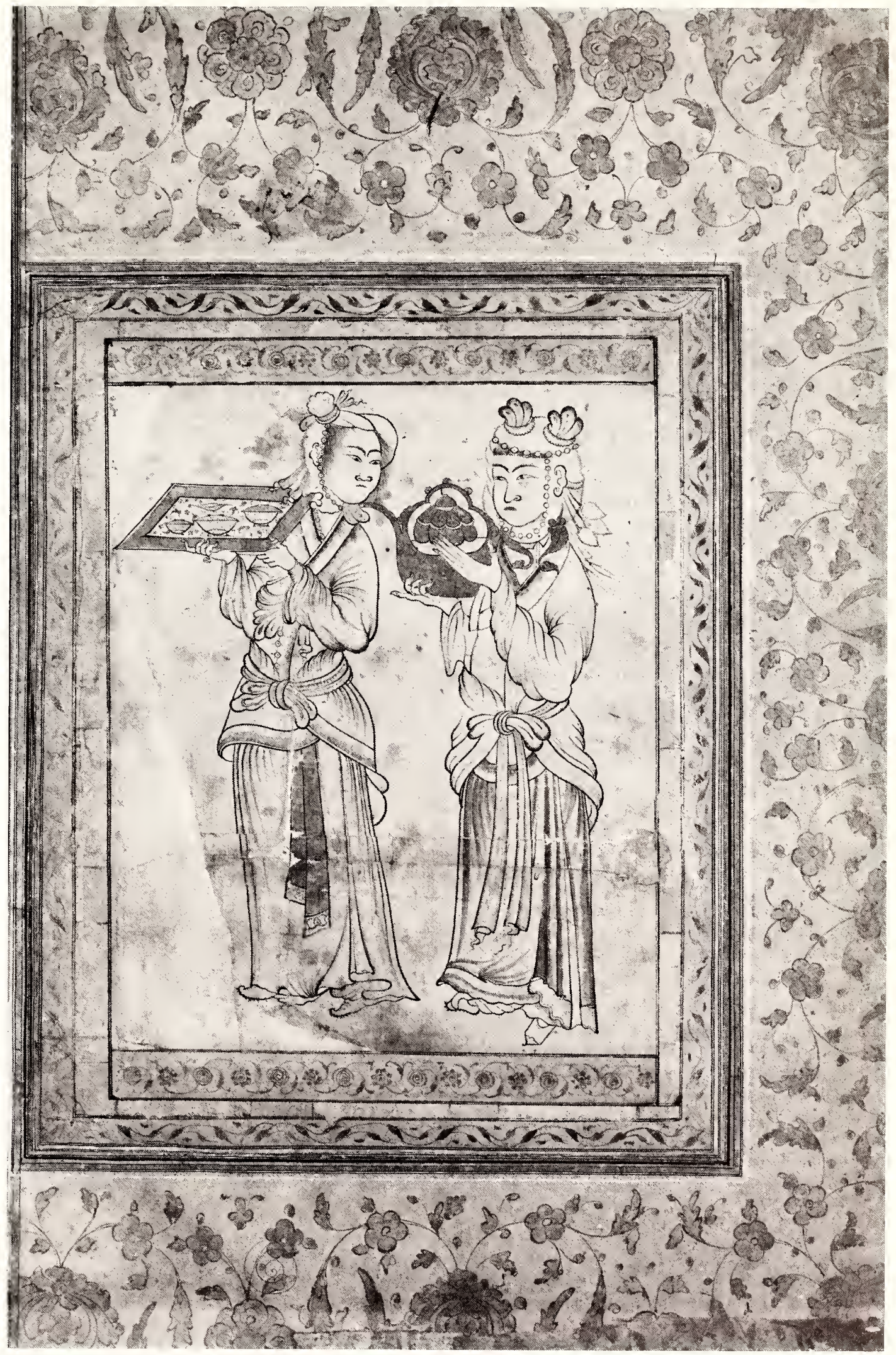




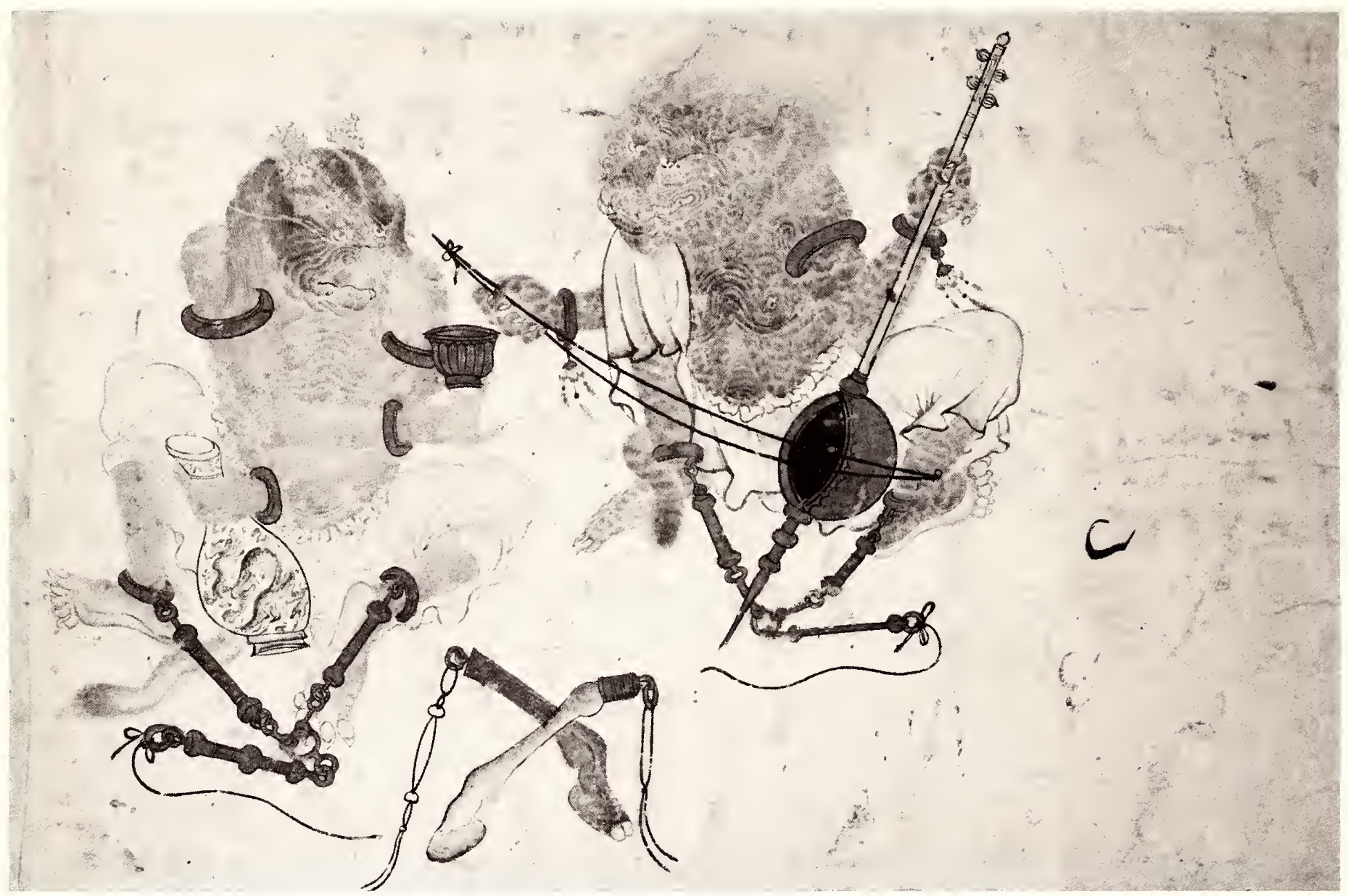

10. Two Fettered Demons Iran or Central Asia, Turkmen or Timurid period, 15th century

Black line and gold on paper; tinted with red and blue

$14.6 \times 22.1 \mathrm{~cm},\left(53 / 4 \times 8^{11 / 16 \mathrm{in}}\right)$ 37.25

The drawing, cut to the edge and mounted on a larger sheet of blank paper, is typical of the series in the lstanbul albums which bear the attribution "Mehmed Siyah Kalem" although revealing variations in style and subject matter A group of these drawings represents fantastic beings (monsters or demons) who are shown singing, dancing or playing musical instruments. The Freer example is unusual in that the demons are shown in shackles while enjoying the pleasures of wine and music. ${ }^{11}$
There is a pathetic quality in the representation of the creatures; even though bound in chains, they are attempting to amuse themselves, accepting their fate as prisoners

The half-naked figures are seated on the ground. One of them holds a blue-and-white porcelain bottle and offers a drink in a fluted cup to his companion; the other plays a type of string instrument which is frequently depicted in the series. Below them are two animal legs with hoofs, used in making music by the shamans of Central Asia.

The bodies of the figures are executed in fine brushwork and washes. The demon on the right has a skirt drawn in blue whereas his partner's garment is in pale brownish red. Thickly applied gold paint with tooled decoration appears in the armlets, bracelets and shackles of the demons as well as in the string instrument, wine cup and handles of the animal legs.

The design on the porcelain botthe, depicting a freely drawn dragon, can be traced to the Yüan dynasty (1280-1386), when the Mongols ruled China, and was popular in the ensuing Ming period. Blue-and-white Chinese wares were very much in demand throughout the Near East and were imported in large quantities and collected by the rulers. The Istanbul albums contain a number of paintings in which similar blue-and-white Chinese porcelains are depicted. 


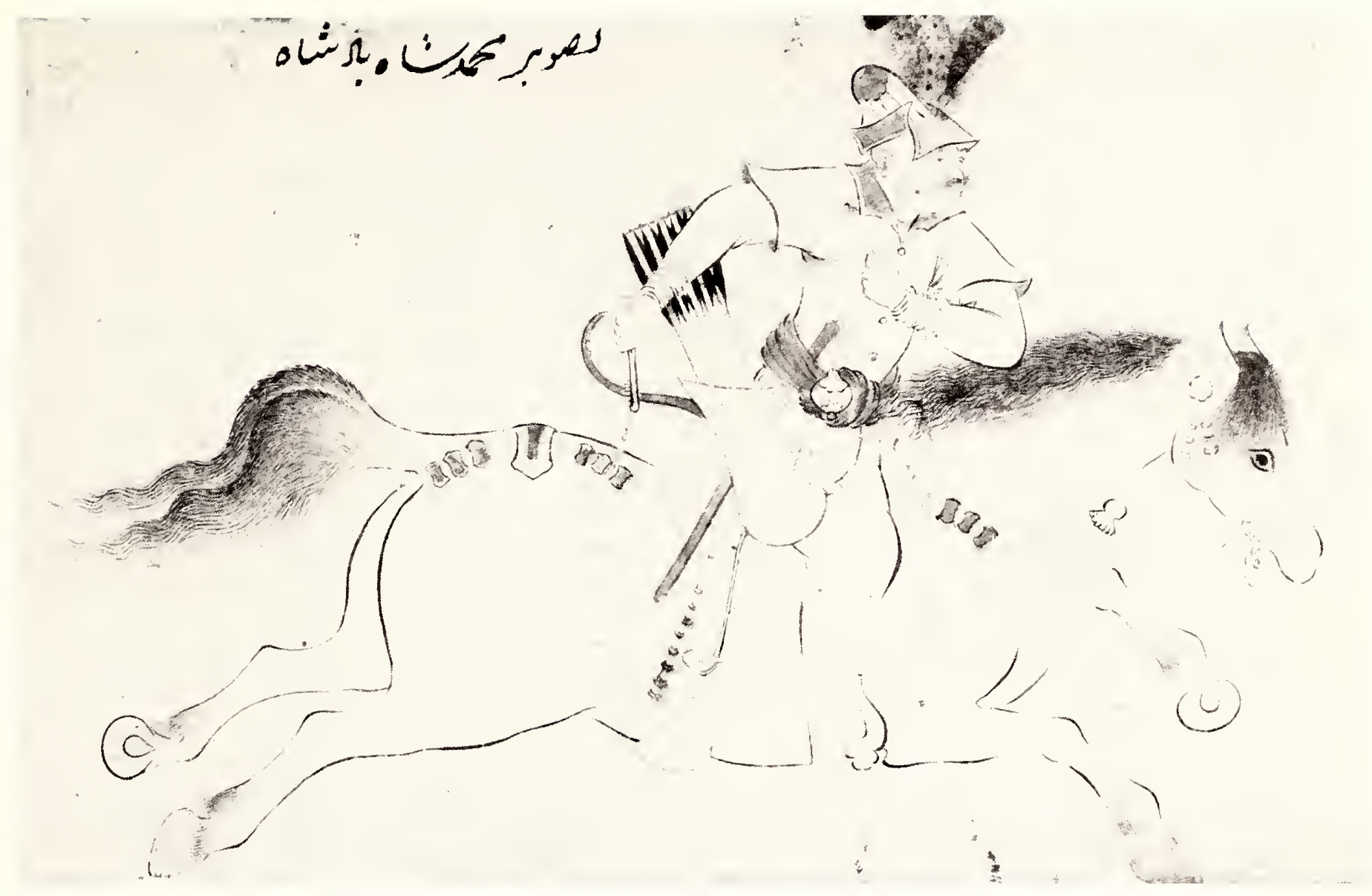

\section{Galloping Horseman} Iran, Turkmen or Timurid period, late 15 th century

Black line and gold on paper; tinted with red

$10.1 \times 15.4 \mathrm{~cm} .(4 \times 61 / 16 \mathrm{in})$ 47.22

This exttemely fine drawing represents a rider urging his mount with a short whip commonly used by Turkmen or Mongol horsemen. The illustration is trimmed to the edge and mounted on catdboard.

Inscribed on both sides is a later attribution which teads: "portrait of Muhammed (or Mehmed) Shah, Padishah." Mulrammed was a popular name among the 15thcentury rulers, used by the

Turkmens and the Jalaitids as well as by the Khans of the Golden Horde who ruled south Russia. The word padishah, or the great shah, was employed from the 15 th century onward by the Ottomans. Since the drawing resembles several other examples included in the Istanbul albums, this inscription was likely added in the Ottoman court and could refet to a number of Muhammeds or Mehmeds, including the Ottoman sultans

The figure is attired in garments of the period: he wears a cap with its split-rim turned down, a short-sleeved jacket over a longsleeved shirt, pants and boots. A bow and quiver with arrows hang at his side while a long staff is tucked into his belt

Black lines define most of the elements; pale red is used to outline the horse trappings, saddle and saddlecloth as well as the quiver, boots and whip of the ridet. Bright red strokes accen- tuate the tiny feathers on the arrows tucked into the quiver.

The horse is depicted in full gallop, running breathlessly with its mouth open. The hoofs on its inner legs are turned upward revealing the hotseshoes and nails Although the theme of a galloping horseman is common in 15 th-century paintings, the turned-up hoofs are unusual. This patticular view appears on several "Mehmed Siyah Kalem" drawings which represent contorted hotses with twisted legs. 


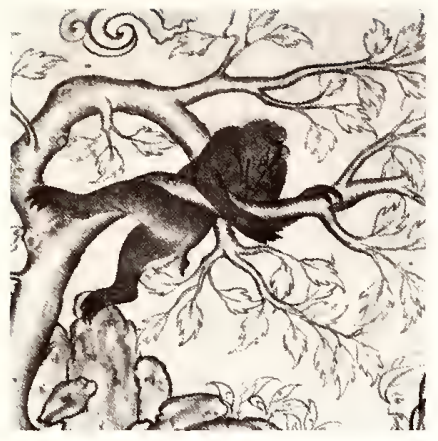

\section{Safavid Period}

The Safavid dynasty (1501-1732) rose from a sufi, or mystic, origin established in the middle of the 14th century by Sheykh Safi al-Din. It became a major power during the reign of Ismail (1501-24), who succeeded in bringing the whole of Iran under his rule despite the threats by the Ottomans in the west and the Uzbeks in the northeast. Shah Ismail conquered Tabriz in 1502, made it his capital and occupied Shiraz the following year. In 1510 he entered Herat and sent a substantial group of Timurid artists back to his capital. Tabriz, which was an important artistic center during the Akkoyunlu rule, flourished under the patronage of Ismail's son and heir, Shah Tahmasp (1524-76).

The early works of the Safavid capital relied on the Akkoyunlu style of Tabriz. Shah Ismail himself was brought up within that artistic environment, having married into the Akkoyunlu family. After the arrival of artists from Herat, a new and vibrant school of painting developed, blending the best of both traditions. Shah Tahmasp had been educated in Herat and brought to the capital his enthusiasm for the arts. He was particularly interested in illustrated manuscripts and supported the painting activities of the court. The artists of his studio executed the illustrations in a monumental volume of Firdausi's Shabname and worked on a number of other literary texts, including the collection of poems written by such celebrated authors as Hafiz and Nizami. ${ }^{12}$

Herat, occupied several times by the Uzbeks, remained in Safavid hands, and artists there continued to create exquisite works rivaling those of Tabriz. ${ }^{13}$ Shiraz was also extremely active, producing at first works in the style of the Akkoyunlu school, then following the Safavid tradition established in Tabriz. Single paintings and drawings became quite popular, and many were collected in albums compiled by Shah Tahmasp and his brother, Bahram Mirza. ${ }^{14}$

Tabriz was on the Safavid border and exposed to recurring Ottoman attacks. In 1514 Sultan Selim captured the city and took a large group of artists to his court in Istanbul. The ensuing sultan, Süleyman the Magnificent, entered the city several times (in 1534, 1538 and 1548), forcing Shah Tahmasp to move the Safavid court to the safety of Kazvin after the last Ottoman attack.

The school of Kazvin initially continued the tradition practiced in Tabriz. However, it soon developed a characteristic manner of representation, depicting elaborate landscapes with thin, tall and elegant figures. During the second half of the 16th century, the studios of Herat and Meshhed were also creative, producing outstanding manuscripts. The artists of Herat were supported by Shah Tahmasp's brother, Sam Mirza, and those in Meshhed were 
under the patronage of the shah's nephew and son-in-law, Ibrahim Mirza. It was Ibrahim Mirza who commissioned one of the last great illustrated manuscripts, a magnificent copy of Jami's Haft Avrang owned by the Freer Gallery of Art. ${ }^{15}$

Following the death of Shah Tahmasp, internal and external disturbances weakened the Safavid rule during the reigns of Ismail II (1576-78) and Muhammed Khudabanda (1578-87). The empire was consolidated and its power reinstated by Shah Abbas (1587-1629) who moved the court in 1598 to Isfahan, which under his patronage became a brilliant cultural center. ${ }^{16}$

Shah Abbas, like his grandfather, Tahmasp, was brought up in Herat, which retained its artistic traditions and activities even though the capitals of the Safavids were always in western Iran. The shah's early education in Herat most likely contributed to his interest in the arts. Isfahan was embellished with spectacular jewel-like buildings and gardens, and its painting studios enjoyed a large and varied clientele, supported by the court, members of the aristocracy, wealthy citizens and foreign collectors. The production of illustrated manuscripts was secondary to single paintings and drawings which were becoming increasingly popular. Drawings were by far the greatest in demand, depicting idyllic scenes as well as mundane subjects. The works were frequently inscribed with the date and the name of the artist and often contained lengthy statements describing the environment in which they were executed.

After the death of Shah Abbas, the Safavid Empire began a slow but steady decline. Abbas had a morbid fear of being overthrown by his heirs and eliminated all his sons. His grandson and successor, Safi I (1629-42), was brought up in the harem due to the shah's paranoia and was virtually unfit to rule. Yet the workshops established by Abbas remained active regardless of the lack of stimulating and demanding patronage. The artists continued producing illustrated manuscripts and single paintings which toward the end of the 17 th century began to follow the new Europeanizing trends.

The Safavid rule came to an end when the governor of Afghanistan declared his independence, and his son, Mahmud, invaded Isfahan in 1722. Various members of the Safavid house were left as puppet rulers for another decade, but the effective rule of the dynasty ended with the fall of Isfahan.

Iran was on the verge of collapse when a remarkable man rose to the occasion and reestablished its territorial integrity. Nadir Shah, formerly in the service of the Safavids, cleared the land of foreign invaders and established his own dynasty, the Afsharids (1736-95). After Nadir Shah's death in 1747 , his heirs were able to rule only in eastern Iran, and the country became divided between various military chiefs. The Zands (1750-94) held the southern regions until the rise of a 


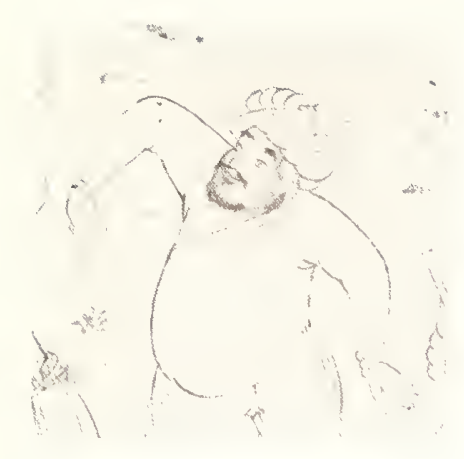

Turkmen tribe, the Kajars (1779-1924), who succeeded in controlling the whole of Iran.

The earliest drawings executed during the Safavid period were made in Tabriz, most likely for the imperial albums favored by Shah Tahmasp and his brother, Bahram Mirza (no. 12). The studios of the second capital, Kazvin, and those of the provincial courts in Herat and Meshhed also produced drawings which were fashionable during the second half of the 16th century (nos. 13-16). A number of examples bear the signatures of the artists, including Muhammedi and Sheykh Muhammed, both of whom executed single-page paintings and tinted drawings (nos. 15, 15A, 16, 16A).

Muhammedi is said to have been the pupil as well as the son of the greatest painter of the age, Sultan Muhammed of Tabriz, who worked in the court of Shah Tahmasp. An inscription on a copy of one of Muhammedi's paintings made by Riza mentions that the artist was from Herat, but little else is known about his life and activities. ${ }^{17}$ According to his dated paintings, he was active between 1527 and 1584. ${ }^{18}$ His early style is very close to that of Sultan Muhammed and as a young man he must have made several paintings and drawings while still living in Herat. One of these early works is a portrait of a youth in the Freer Gallery of Art and another is a drawing of an angel in Boston. ${ }^{19} \mathrm{He}$ is also mentioned as having painted lacquer bookbindings which were coming into fashion in the Safavid court.

Muhammedi was a master of single-page paintings and drawings, and there are a number of examples either attributed to him or bearing his signature. An album leaf in Boston contains a figure of a man holding a drawing and a pen with an inscription that states: "the work of Muhammedi, the portrait of Muhammedi." 20 His signed paintings depict lovers in a landscape or individual portraits of men or women, including a young prince in a brocaded coat in the collection of the Freer Gallery of Art (no. 15A). ${ }^{21}$ Among his signed drawings are studies of mystics and dervishes and an outstanding representation of a pastoral scene which bears the date $1578 .^{22}$ Muhammedi reached his mature style around 1575, during the reign of Tahmasp's brother, Shah Ismail II.

Sheykh Muhammed was the son of a calligrapher and studied painting with the famous Dust Muhammed, one of Shah Tahmasp's court artists. He worked in Tabriz and Kazvin under several royal patrons until the turn of the century. His earliest paintings are thought to be in Shah Tahmasp's Shahname executed during the 1530s and 1540s. Sheykh Muhammed's fully developed style is seen in Ibrahim Mirza's Haft Avrang which was copied in Meshhed, Kazvin and Herat between 1556 and 1565. In the last quarter of the 16th century, the artist joined the ateliers of Shah Ismail II and 


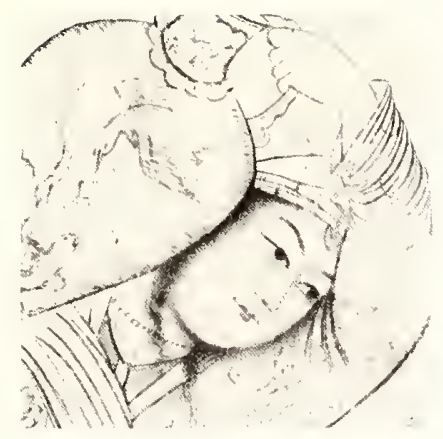

Shah Abbas. Sheykh Muhammed's only signed and dated painting, executed in 1556-57, is in the Freer Gallery of Art (no. 16A).

The artist is said to have imitated Chinese styles and was the first to introduce European painting traditions into Iran; however, we have no evidence of these activities. His signature appears on three drawings, one of which, representing a kneeling youth holding a parakeet, is included in the exhibition (no. 16). The second example is almost identical, depicting a youth with a book, while the third represents a dervish. ${ }^{23}$ Sheykh Muhammed's paintings also influenced Riza who copied one of his drawings. ${ }^{24}$

Drawings from the school of Isfahan are far more numerous and include many signed and dated examples, such as those made by Mirza Muhammed al-Huseyni (no. 18), Muhammed Muhsin (nos. 25 and 26), Riza (nos. 19, 28-33) and Muin Musavvir (nos. 26 and 34).

Muhammed Muhsin appears to have been working in Isfahan in the middle of the 17 th century since two of his signed drawings bear the date 1649 (no. 24). ${ }^{25}$ A reference to this artist mentions that he was from Tabriz and studied with the calligrapher Mahmud Shahabi who died in 1583 in Herat, his native town. ${ }^{26}$ Another source states that Muhammed Muhsin "al-Arshi" was a calligrapher who worked in Isfahan and died in $1680 .{ }^{27}$ If these two men are one and the same, then the artist first studied in Herat and later moved to Isfahan. He also had an exceptionally long life. An album page in the India Office Library contains a sheet of calligraphy signed by Muhammed Muhsin "al-Haravi," that is, from Herat. ${ }^{28}$ Two drawings of dervishes are attributed to him, one of which bears the name Muhsin. ${ }^{29}$ The artist appears to have been a calligrapher as well as a painter, which was not unusual in the Safavid period.

The most prolific and influential painter of the Isfahan court school was Riza, who signed his name either as Aka Riza or as Riza-i Abbasi; according to his dated works, the artist was active between 1587 and 1639. ${ }^{30}$ He was born around 1565 in Meshhed; his father, Ali Asghar, was a painter in the ateliers of Ibrahim Mirza and Shah Ismail II. Riza appears to have joined the court of Shah Abbas in 1587 and immediately set to work on a royal Shahname (ca. 1587-97). ${ }^{31}$ Although his paintings appear in other illustrated manuscripts - such as the Kisas al-Anbiya (ca. 1600), the Divan of Ali Shir Nevai (ca. 1620) and the Khosran va Shirin (dated 1632) ${ }^{32}$ - he is far better known for his single-page studies. These paintings are characteristic of the style of the school of Isfahan, generally representing single figures lost in their own dreamworlds (nos. 19A and 19B). His drawings, executed in delicate and sinuous lines, depict figures in rather exaggerated poses (nos. 19, 27-33). 


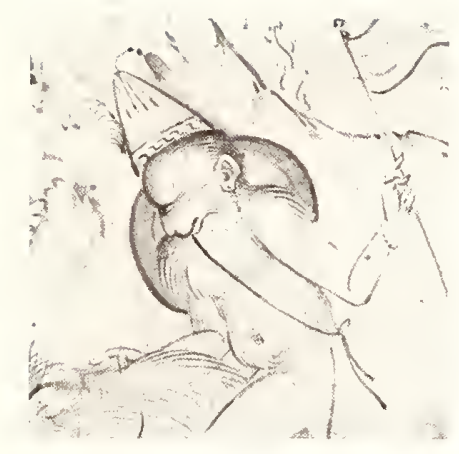

Riza abandoned his career in the royal atelier around 1605 , taking up with lowbred companions in preference to the affected elite of the court. He returned to his profession in 1615 and produced an enormous number of single-page drawings until his death, which occurred about 1640. His works were copied and imitated by such a large group of followers that the school of Isfahan became identified with that of Riza.

Muin Musavvir was the most gifted of Riza's numerous students and followers and possibly the last great Safavid painter. His dated works fall between 1635 and 1707, and during his long career he worked in the traditional manner, avoiding the Europeanizing trend which was popular among his contemporaries. Muin was a great draftsman and an excellent painter, executing single-page drawings and paintings as well as manuscript illustrations, including several copies of the Shahname and a history of Shah Ismail. ${ }^{33}$ His drawings are far more numerous than his paintings and generally depict studies of single figures (nos. 26 and 34).

The majority of the drawings from the late Safavid period owned by the Freer Gallery of Art belong to a collection popularly called the "Riza-i Abbasi Album." The album consists of 60 drawings mounted on 49 sheets, seven of which have two to four small sketches pasted together (53.12-53.60).

The work was formerly in the collection of Friedrich Sarre who published a monograph in 1914 which included an extensive study on the album and facsimiles of the drawings. ${ }^{34}$ The author states that the drawings were bound in a lacquer binding dating from the first half of the 18th century and suggests that the album was compiled at that time. Irregular strips of red and buff paper were used to frame the drawings, which were pasted on coarse cardboard leaves measuring 26.4 by 18.6 centimeters $(103 / 8$ by $75 / 16$ inches); these leaves were attached to one another in a concertina-form, a most unusual format for Near Eastern manuscripts. However, on one of the drawings there is a later inscription which gives the name of the owner and the date 1297 Hijra, that is, 1879 A.D. (no. 28). Therefore, the album was assembled in the last quarter of the 19th century which accounts for its unconventional manner of compilation. The drawings must have been pasted on cardboard sheets cut to fit the 18th-century lacquer bookbinding. When the album was purchased by the Freer Gallery of Art in 1953, it was already unbound and the leaves separated; the binding and four of the drawings illustrated in Sarre's book were also missing. ${ }^{35}$

The collection contains a number of signed and dated drawings and sketches, ranging from 1598 to 1643. Among the dated examples are several bearing the names of Riza and Muin, while the remaining appear to belong to Riza's school 


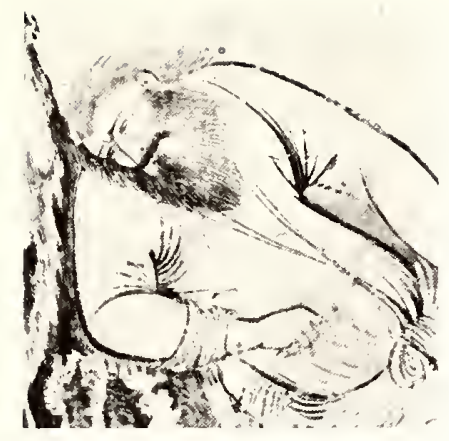

and show a close affinity to the master's style. The majority of the drawings were made during the reign of Safi I, the successor and grandson of Shah Abbas.

Included in the exhibition are 34 sheets, four of which have a pair of drawings pasted together (nos. 27-60; double drawings nos. 37, 39, 47 and 54). The drawings in the exhibition are arranged in groups of signed and dated examples (nos. 27-34), dated pieces (nos. 35-44), those that have written comments (nos. 45-47) and others without any inscriptions (nos. 48-60). Seven of them bear inscriptions giving the name of the artist as Riza, Riza-i Abbasi or Aka Riza (nos. 27-33). With one exception (no. 32), these drawings are dated between 1598 and 1639, covering a major portion of the painter's life. Three other examples contain the name of Muina, identified as Muin Musavvir, and are dated 1639-43. One of them was made by Muin himself (no. 34), whereas the inscriptions on the other two indicate that they were either executed in his house or contain a reference to him (nos. 37 and 44).

Since the drawings in the album cover a period of at least 55 years, there is quite a variation in the tone of the papers, subject matter, manner of execution and style of writing. The papers, uniformly polished, range from pale cream and buff to a deeper tone which is almost tan; one scene is painted on a colored sheet (no. 46). Some of the drawings are obviously finished examples and contain the names of the persons who commissioned them. They were generally ordered by unknown personages, such as wealthy merchants and doctors (nos. 27, 29 and 35); only one example states that it was specifically made for the Imperial Treasury (no. 33). Several are sketches for manuscript illustrations, such as the Layla va Majnun and Yusuf va Zulaykha series (nos. 38 and 60), or book decorations (nos. 57 and 58). A number of examples have fine pierced holes following the lines, indicating that they were used as stencils (nos. 29, 56 and 58). White lead was employed for correction on several drawings and appears now as a dark-gray stain on the paper (no. 47).

Black line is used on a majority of the examples although there are a few rendered in red and black or solely in red; rarely do the scenes reveal polychrome tints. The style of inscriptions vary; some are almost as sketchy as the drawings and quite difficult to read. It is surprising that the inscriptions are so highly detailed and precise, giving the exact day the drawings were made, in whose house and under what conditions. This extraordinarily informative manner of inscribing the drawings is a characteristic feature of the period.

Although the inscription of one example states that it was made in Meshhed (no. 27) and another in Herat (no. 45), the entire album follows the style identified with the school of Isfahan. 
12. Ascension of Solomon

Iran, Safavid period, early 16th century

Black line and gold on paper; tinted with red, blue and green Page: $35 \times 24 \mathrm{~cm}$ ( $133 \frac{3}{4} \times 9^{7 / 16}$ in.)

Drawing: $30.8 \times 19.8 \mathrm{~cm}$ $\left(121 / 8 \times 7^{13 / 16}\right.$ in $)$

50.1

The drawing, mounted on heavy paper and framed with several gold lines, represents the celestial journey of a crowned figure seated on an octagonal throne. Accompanying him are various winged creatures: peris (fairies or angels) and jinns (genies or demons), who either play musical instruments bear vessels with offerings or carry animals. The composition is almost concentric with the elements radiating from and swirling around the central personage.

\section{A strip of land appears on the} lower edge of the scene with jagged hills and vegetation among which a rabbit sleeps peacefully Inmediately above are winged figures carrying diverse animals and birds such as deer, leopard, mountain goat, peacock and duck; one of the figures bears a longnecked bottle on a tray. In the second register are three peris who hold covered bowls and a plate of fruit; behind them is a dancer with a pair of clappers who sways to the music of a trio which includes horn, lute and tambourine players.

The crowned figure is in the center of the scene, his throne carried by a pair of peris. Two figures hold a billowing canopy over his head; surrounding the throne are other attendants who play a flute, carry a fan or incense burner, or lead the way. A horned creature flies in front of the group which is followed by a four-armed peri holding a lute, wine bottle, and cup and saucer.

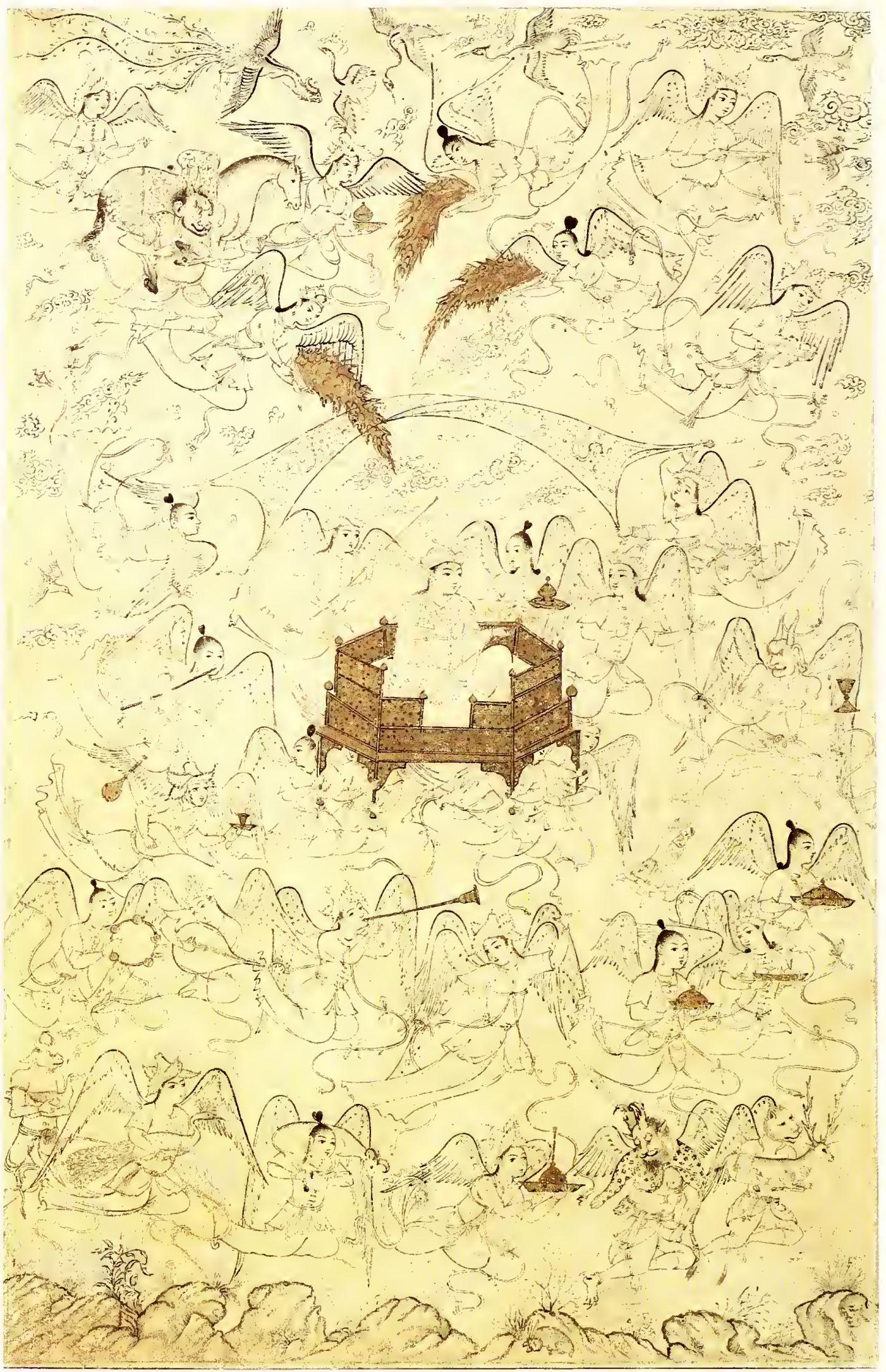




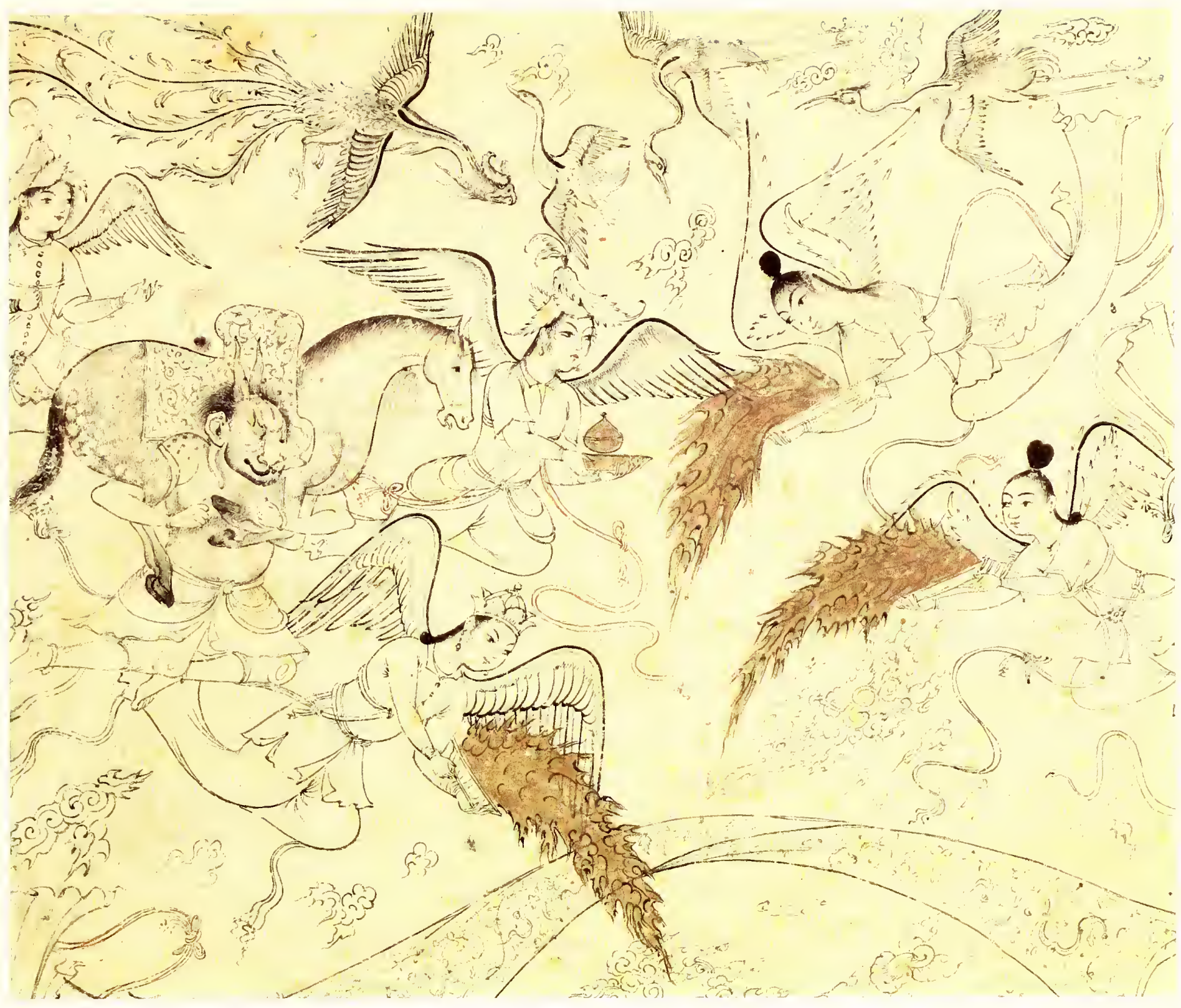

On the upper portion are more winged creatures: peris bear a plate of fruit, covered bowls or an incense butner; a jinn carries the king's horse on his shouldet; and three othet angels pour celestial fire over the ruler. Real and fantastic birds, such as a crane and a phoenix, accompany the travelers.

This highly detailed scene is executed in black with gold used exclusively in the heavenly fire, on the thtone, musical instruments and vessels; the throne and vessels are enctusted with red, blue and green gems. Soft washes of red enhance the hills in the foreground and define some of the long tibbons tied around the totsos of the winged females.

The princely figure is identified as Süleyman, or King Solomon, who travels through the heavens on his flying throne accompanied by the animals and beasts of his legendary kingdom. The hoopie used by Solomon to send messiges to Belkis, the Queen of Sheba, is seen on the upper right

This particular drawing must have been extremely popular and served as the model fot two paintings, one of which was made in Istanbul around 1600 and the other executed in Golconda in the 1680s ${ }^{36}$ The Freer drawing was formerly in an album belonging to the Ottoman Palace, which accounts for its Turkish copy. ${ }^{37}$

Howevet, it is difficult to trace the otigin of the Indian rendition. Both paintings are so close to the Freer example, in size as well as in composition, that it is implausible to think of a second version which would have been used by the Golconda paintet. It is more likely that the Indian painting was traced from the Turkish copy.

The Freer drawing is a product of the early Tabriz school, showing a blend of Timurid-Herat and Akkoyunlu-Tabriz styles. 
13. Garden of Heavenly Creatures Iran, Safavid period, mid-16th century

Black line, gold and silver on paper; tinted with red and blue Page: $27.9 \times 17.2 \mathrm{~cm}$

$\left(11 \times 6^{13 / 16}\right.$ in.)

Drawing: $32.1 \times 21.4 \mathrm{~cm}$

$25 / 8 \times 81 / 2$ in.)

50.2

Similar to the previous drawing, this example is mounted on heavy paper with several gold lines framing the scene. It was also formerly in the imperial libraries of the Ottoman sultans. ${ }^{38}$

The scene depicts a garden with a group of peris entertaining their queen who is seated in a tree guarded by a jinn. A stream of water springs from the rocks in the middle of the scene and flows through the foot of the tree, cutting diagonally across the composition. This diagonal line is repeated by the steps leading to the tree house and balanced by the horizontal placement of the figures and the vertical thrust of the plane tree.

In the foreground are a pair of musicians playing a flute and tambourine and a dancer. Next to them are an amorous couple with an attendant who offers the lovers a cup of wine. Beyond the stream is a jinn leaning on a staff, guarding the entrance to the tree house Several figures ascend the steps, carrying bowls of fruit and other delicacies; at the foot of the steps, one of the peris hands a bowl of fruit to an attendant. The queen of these heavenly creatures sits on the balustraded platform, leaning against a cushion; she is picking a fruit from a bowl offered by an attendant while another peri, sitting on one of the branches, plays a lute.

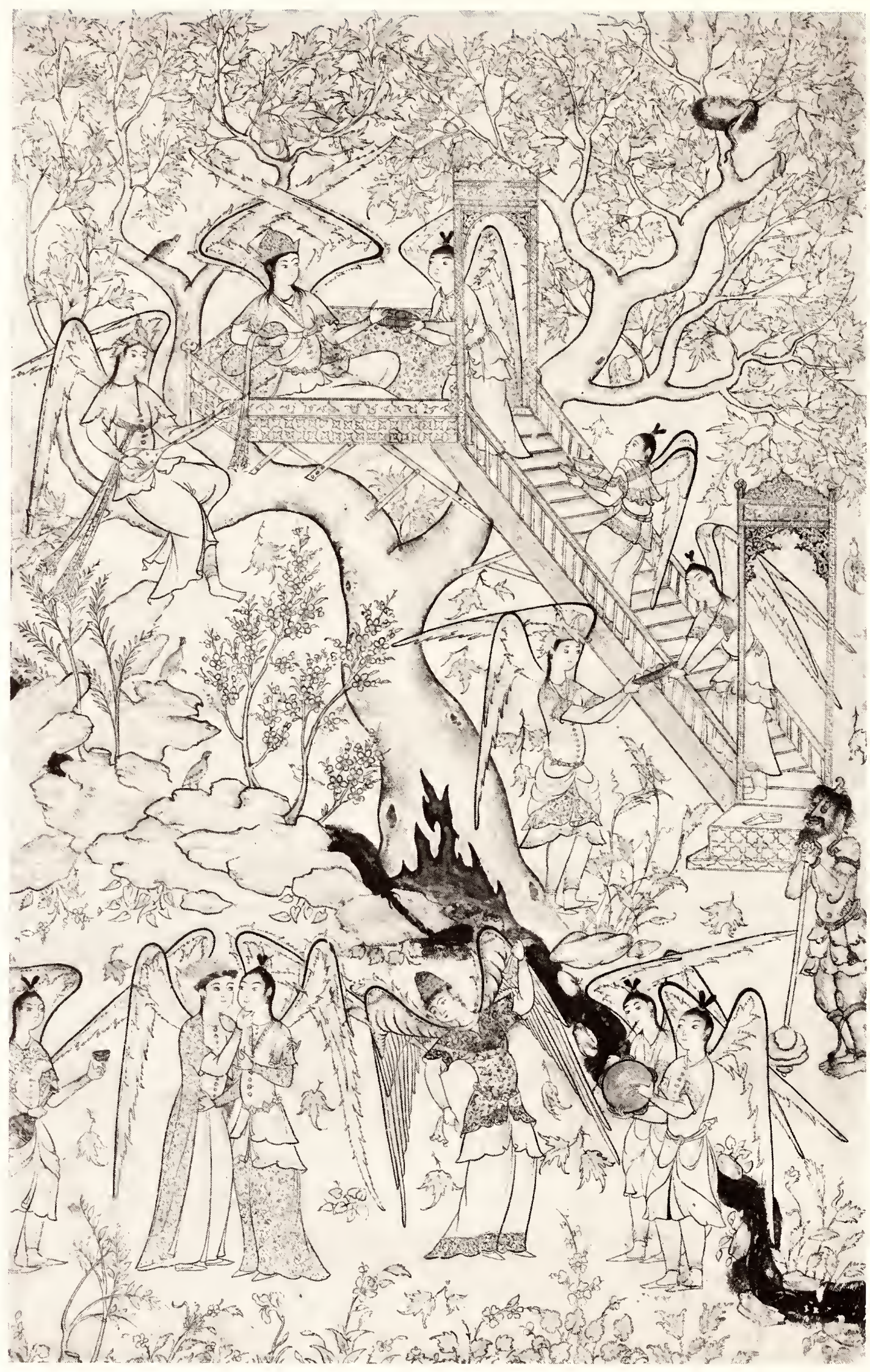




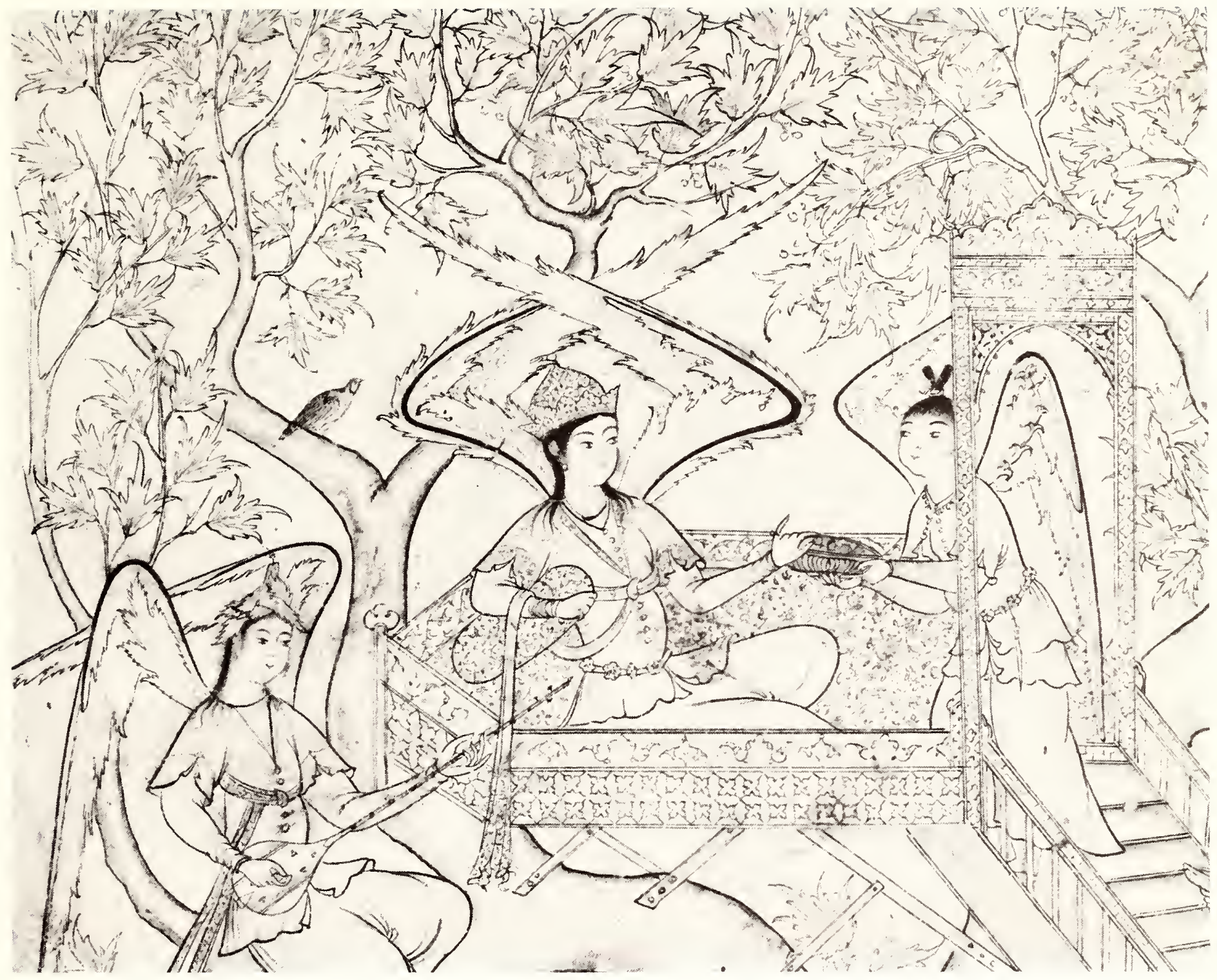

The platform and the two gates at the bottom and top of the stairs are adorned with delicate floral and geometric motifs. Similar intricate designs appear on the garments of the figures. The background is densely filled by the luxuriously foliated plane tree, blossoming branches, sprays of leaves and clusters of flowers; it is enriched by such details as birds perched on rocks or branches and softly falling leaves.

The paradisiacal garden is not entirely devoid of unpleasantness. On the upper right, a snake has attacked a bird's nest and is devouring one of the infants while the mother flutters helplessly above.
The scene is executed in crisp lines and washes of red and blue which soften the landscape and architectural elements. Gold is used on the metallic objects such as the vessels held by the peris and the jewelry of the jimn and on the cape of the dancer. The silver pigment applied to the stream has oxidized, appearing now as dark gray.

The exuberant landscape, jagged rocks and tall elegant figures suggest that the drawing belongs to the Kazvin school which flourished after Shah Tahmasp moved his court to that city in 1548 


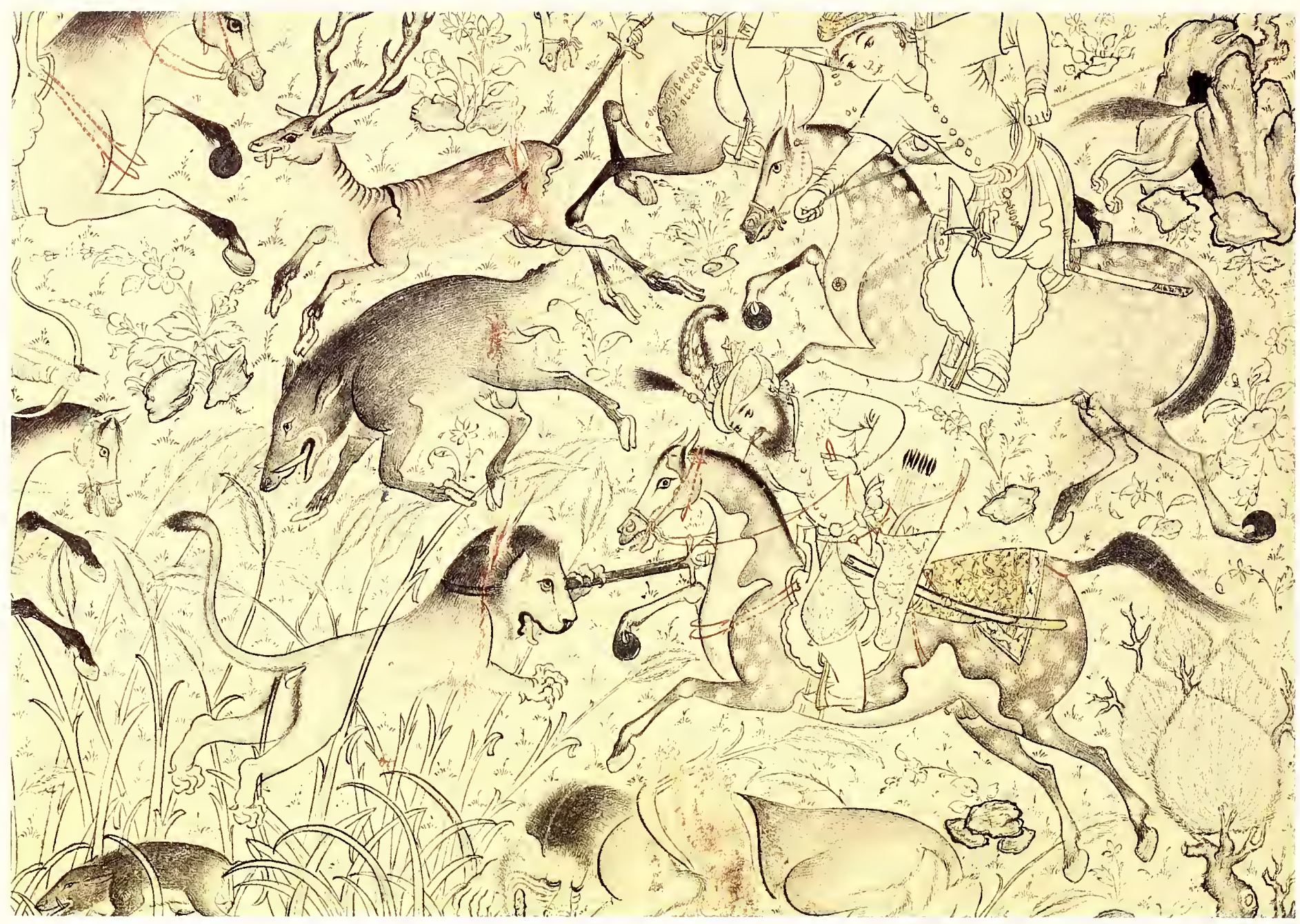

\section{Imperial Hunt}

Iran, Safavid period, mid-16th century

Black line, gold and silver on paper; tinted with red, blue and green

Page: $33.5 \times 23.2 \mathrm{~cm}$.

( $133 / 16 \times 91 / 8 \mathrm{in}$.)

Drawing: $30.3 \times 20.4 \mathrm{~cm}$

$\left(11^{15 / 16} \times 8^{1 / 16}\right.$ in $)$

54,32

This tinted drawing is pasted on an album sheet which is painted beige with grold floral motifs adorning the margins. On the back there is an illuminated poem written in mastalik and set in four columns. Gold lines frame the text and drawing on both sides of the folio.

The scene depicts an imperial hunt with nine riders about to converge at the center, galloping after their prey from opposite sides of the folio. The extraordi- nary movement created by animals and men begins on the lower portion and moves up the composition in a dynamic zigzag formation, each element counterbalanced by another

In the foreground is a body of water, its shore lined with rocks and reeds. The princely hunter on the lower right slashes the neck of a lion with his sword while a bleeding lion lies dying on the ground. The prince is elaborately dressed in embroidered garments and bears a jeweled tassel and feather in his turban. On the next register, a hunter with a bow and arrow shoots at a boar which is speared by another rider. Behind them, two hunters with swords attack a stag and another pair of riders chases onagers, trampling a mountain goat. On the upper right, a huntsman rushes to the aid of a rider who is surprised by two leopards; one leopard tears at the horse and the other pounces upon the rider

The ferocious hunt is being observed by a bear who has escaped to the safety of a tree and follows the activity while wrapped around a branch. Three figures appear among the jagged and animated mountains in the background; one of them indicates his bewilderment by the traditional gesture of bringing an index finger to his lips while pointing to the figure aiming his musket on the wild goats or sheep perched on the craggy rocks.

While the hunters are rushing after their kill, foxes and rabbits scurry around, jump into crevices in the rocks or peer cautiously out of their dens, alerted by the commotion

Most of the drawing is executed in black lines and washes. Occasional details of the landscape, a few animals and portions of the garments are rendered in pale red, blue and green tints. Gold appears in the metal parts of the weapons, horse trappings and garments as well as on the brocaded saddlecloth of the prince; the eyes of the bear perched on the tree are also painted gold, stressing the creature's state of anxiety and fright.

On the lower left is a seal which is too unclear to decipher. The drawing is attributed to the Kazvin court and thought to belong to the school of Sultan Muhammed, one of the most celebrated artists of the age 
(n)

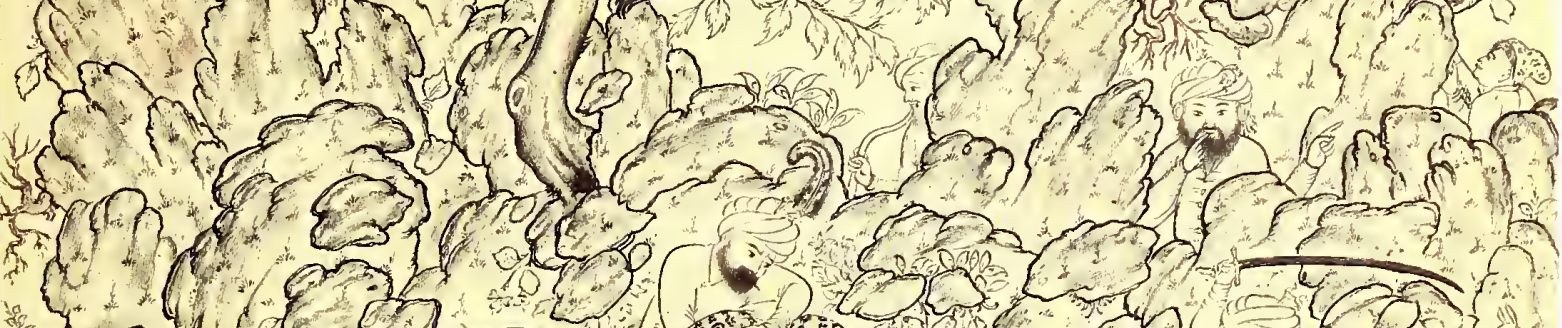
m

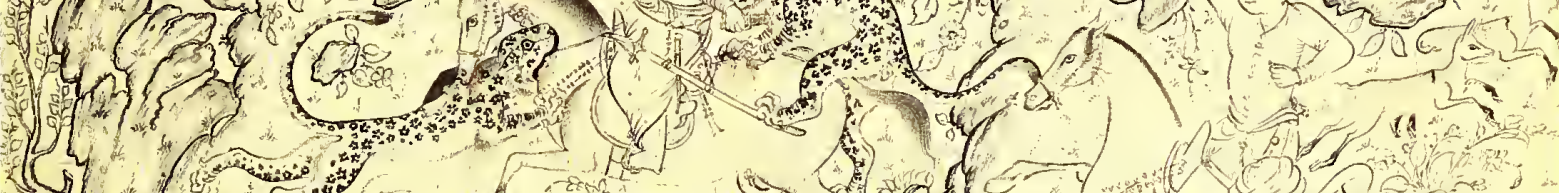
If (n) $\quad$ or $=5$ -

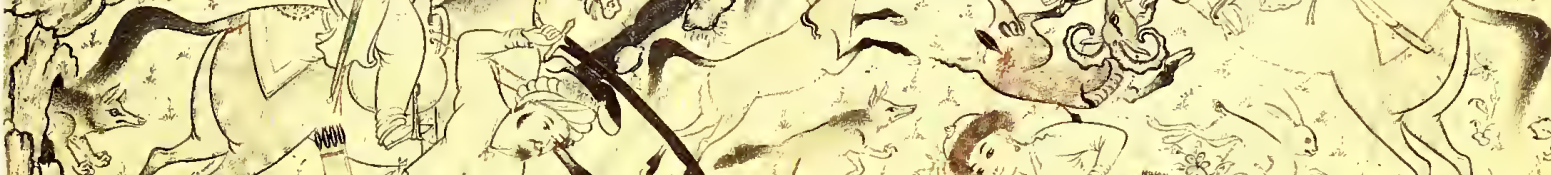

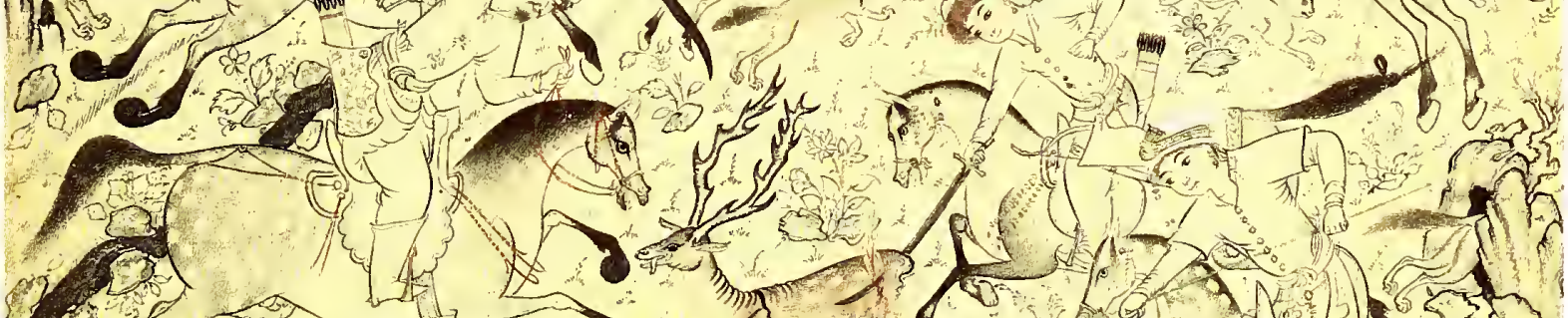
a $-1,25$

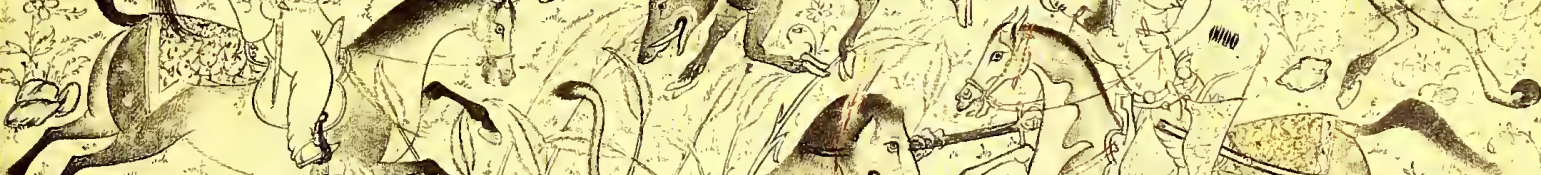
- - - 1

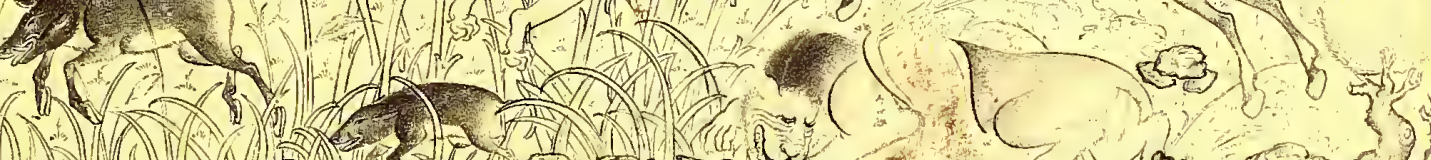

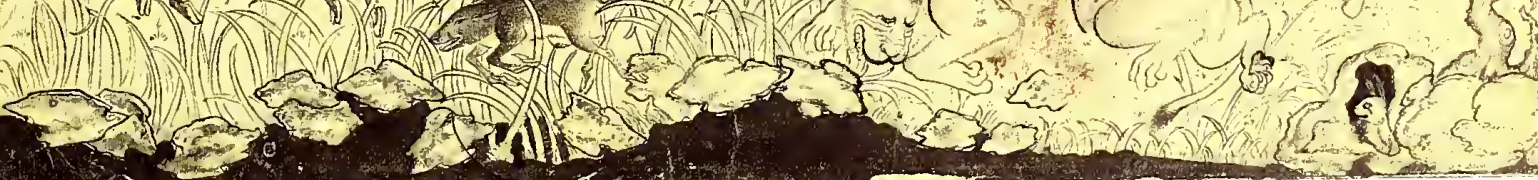


15. Dancing Sufis

Attributed to Muhammedi

Iran, Safavid period, ca. 1575

Black line and gold on paper; tinted with red

Page: $45 \times 30.3 \mathrm{~cm}$. (1711/16 $\times 11^{15} / 16$ in.)

Drawing: $15.2 \times 11.1 \mathrm{~cm}$. ( $6 \times 4 \frac{1}{2}$ in.)

46.15

This folio represents the characteristic format of a page from a murakka, or album, in which select examples of paintings and drawings are combined with samples of calligraphy and illumination. Each page was carefully designed, the illustrations and text forming a harmonious and wellbalanced composition. Singlepage paintings or drawings were very popular in the 16 th century and the compilation of albums became highly fashionable in the court. Signed works were particularly desirable and a great number of these albums include the best works of past and present painters and calligraphers.

This composite folio contains a drawing of dancing sufis, or mystics, by Muhammedi; a painting of a cluster of primroses by Murad; an unsigned text in prose, followed by a verse of poetry with an illuminated heading, both written in nastalik; a poem with five verses, written by Shah Mahmud in a fine nastalik script; and several strips of illuminated bands. The margins of the folio are tinted turquoise and adorned with gold motifs; gold and colored lines frame the illustrations, texts and illuminations which are enclosed by a scroll of gold arabesques. The seal on the draw- ing reads: "the slave of the King of Holiness (that is, Ali, the fourth caliph and the founder of the Shiite sect), Abbas, in the year 995 (1587)." The date on the seal must refer to the year in which the album was compiled, since the style of the drawing indicates that it was executed in Kazvin in the 1570 s (see also no. 19A). Presently, the folio is mounted on a blank cardboard.

The poem with five verses, or 10 hemistichs, is written on an angle and follows the format of specimens of calligraphy executed for albums. The inscription, "the slave Shah Mahmud has written it," appears in a cartouche at the bottom. Shah Mahmud, a native of Nishapur, worked in the atelier of Shah Tahmasp and copied the most famous manuscripts of the century, including the celebrated Haft Avrang of Jami in the Freer Gallery of $\mathrm{Art}^{39}$ and the Khamsa of Nizami in London. ${ }^{40}$ The calligrapher, called "Zarin Kalam," or "Golden Pen," excelled in both large and small types of script and wrote a number of poems. He spent the latter part of his life composing poetry and working on calligraphy in Meshhed where he died in 1564.41

The painting of the primroses bears the inscription: "the work of Ustad (Master) Murad." Two artists with the name Murad, both of undistinguished fame, are associated with the Safavid court:

Murad Daylami was in the atelier of Shah Tahmasp, and Murad ibn Ali was in the court of Shah Abbas. ${ }^{42}$ It is more likely that this painting was made by the second artist. 


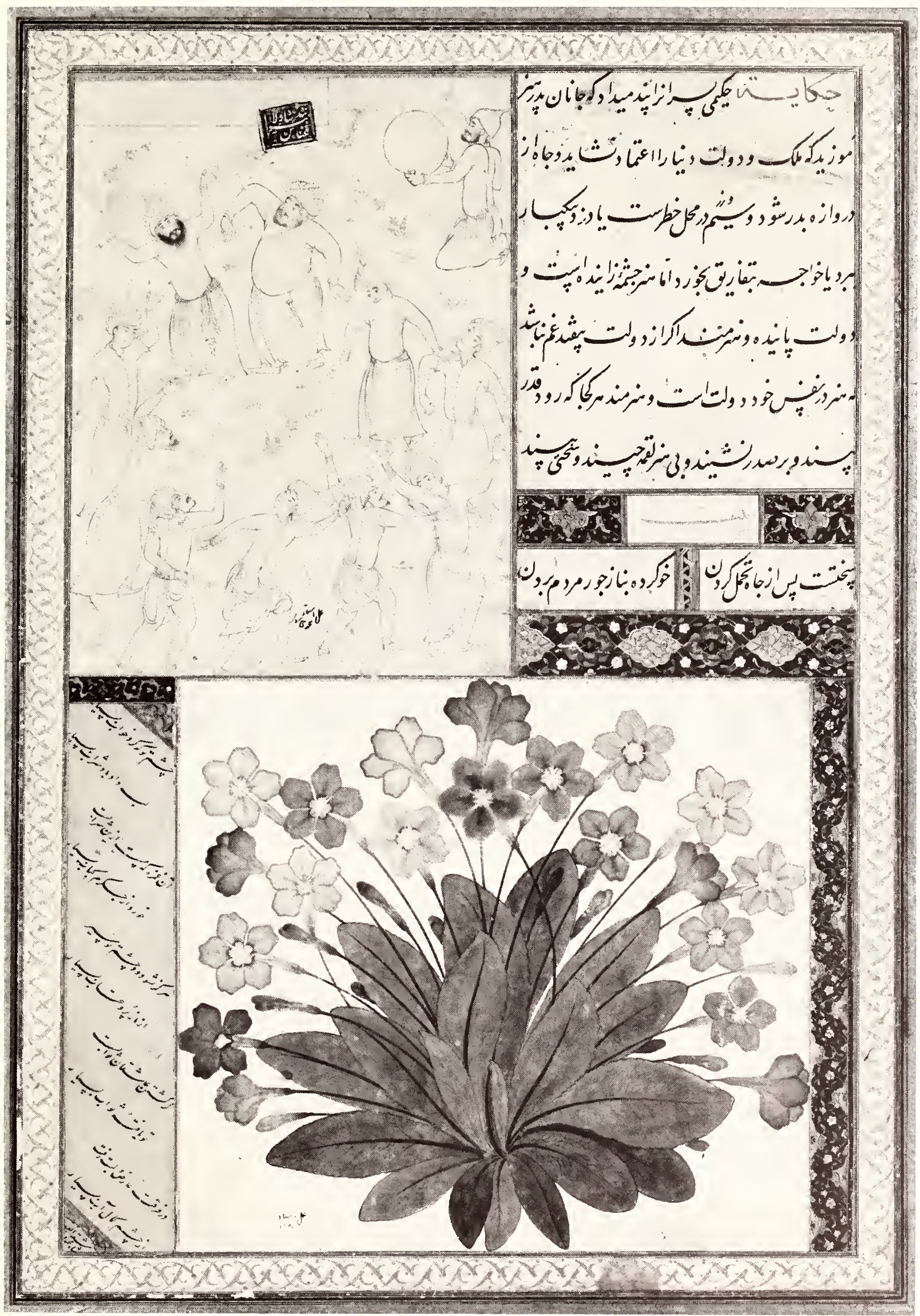


The inscription on the drawing of the dancing sufis, written in the same hand as the one on the painting, states: "the work of Ustad Muhammedi Haravi," referring to Muhammedi who was from Herat. The attribution seems to be accurate since the same fine style of drawing and this same subject matter are found in other works reliably given to Muhammedi. The scene is executed in delicate lines with gold paint used exclusively in the floral sprays scattered around the ground and red washes reserved for the faces of the figures.

The 10 sufis are depicted in naturalistic and spontaneous poses, dancing in a circle to the rhythm of the tambourine played by the kneeling figure on the upper right. The figures are humorously represented, each doing his best, turning and swinging with raised arms. The three sufis on the top-a short stocky personage, a bearded middle-aged man and an elderly figure with a white beard-are portrayed with a marvelous sense of humor; the intense concentration of the first, the awkward pose of the second and the attempted agility of the third present excellent character studies. The others in the group are either beardless youths shown in three-quarter view or middleaged men with prominent noses and chins drawn in profile.

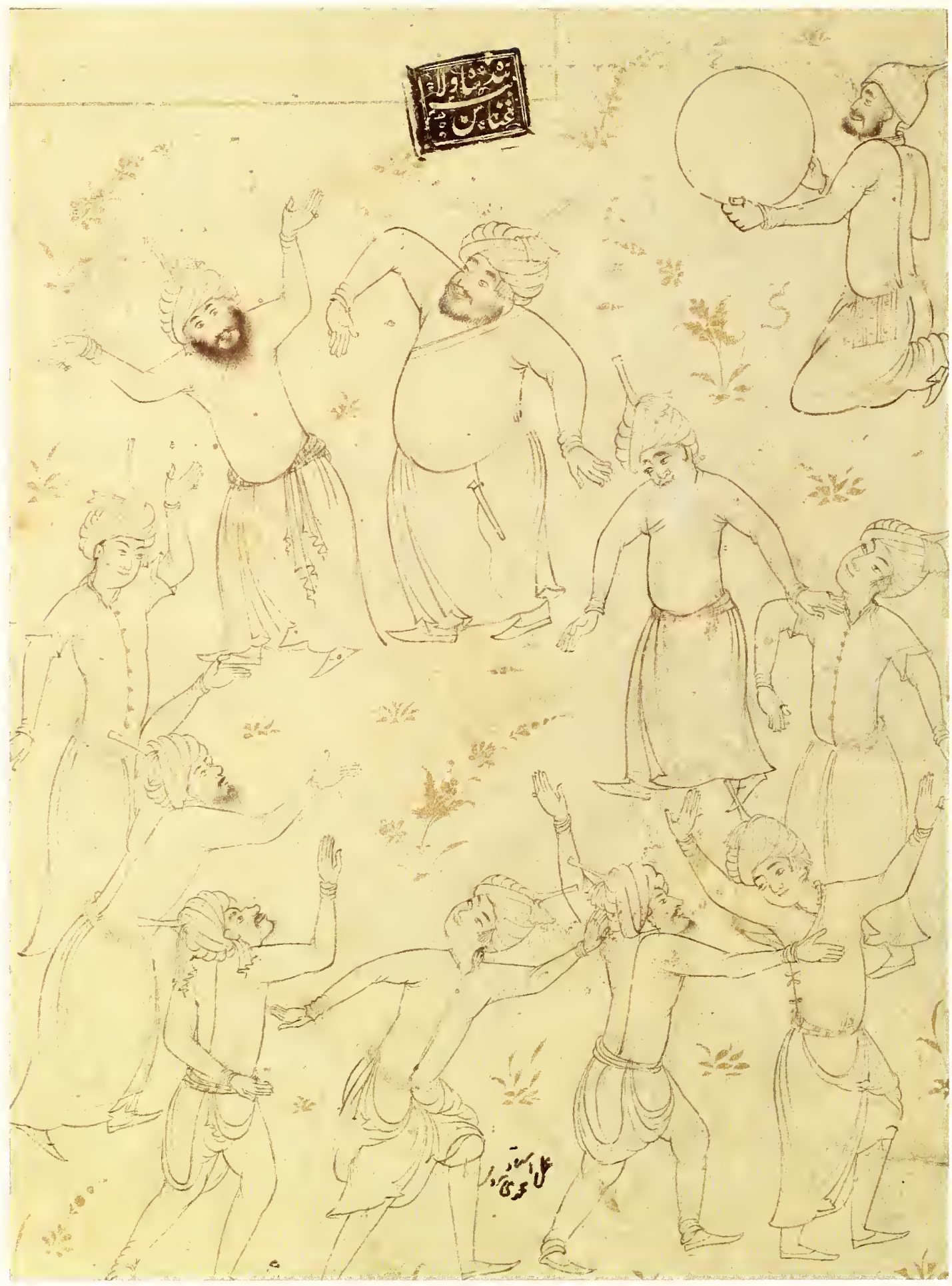


Muhammedi, whose works were discussed earlier, was also a firstrate painter. His signature, rendered as "the work of Muhammed Haravi," appears on the portrait of a young Safavid prince 37.8 , no. 15A) which once belonged to another album. The verso of this folio contains a sample of calligraphy executed by Muhammed Riza in 1574 . The same round face with almond eyes and the tapered turban with a tall baton appear on the youthful sufis. The execution of the prince is highly polished, intentionally labored and refined in contrast to the lively youths in the drawing. The elaborately brocaded coat, adorned with scenes of warriors capturing prisoners, is a rare depiction of the famous figural textiles of the Safavid court

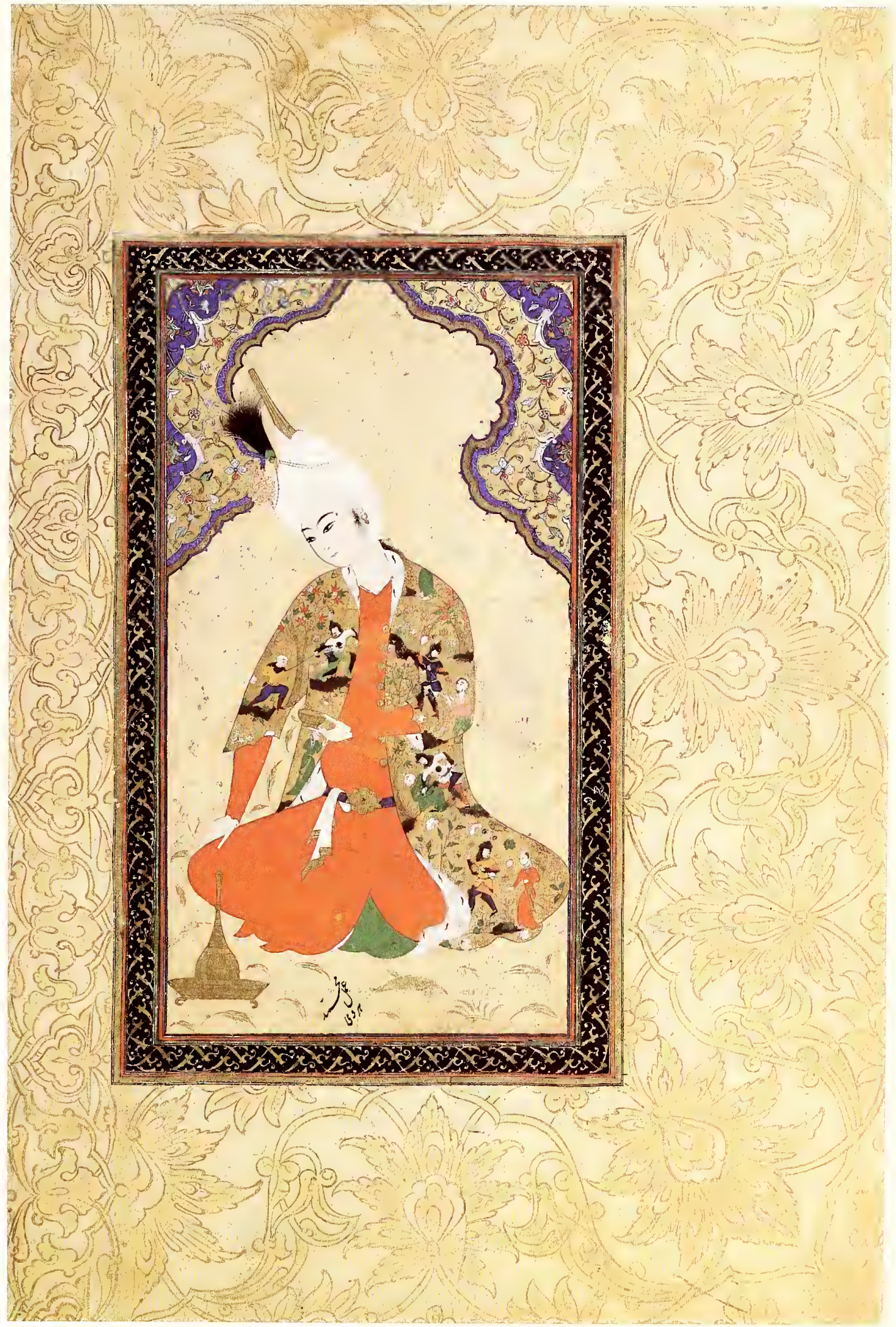

15A. Portrait of a Young Prince

Signed by Muhammed Haravi

Iran, Safavid period, mid-16th century (37.8) 


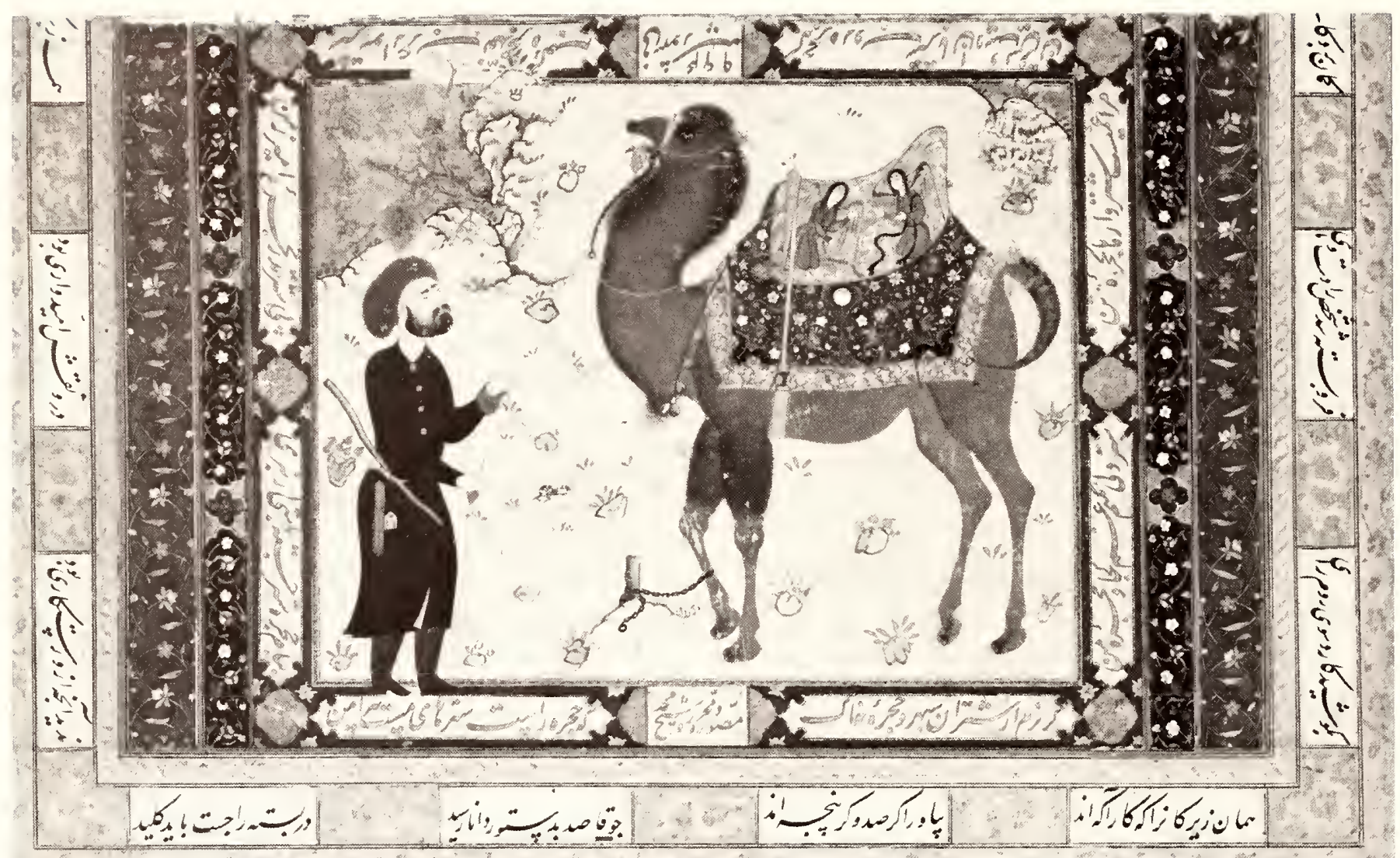

16A. Camel and Keeper

Signed by Sheykh Muhammed

Iran, Safavid period, dated 1556-57

(37.21)

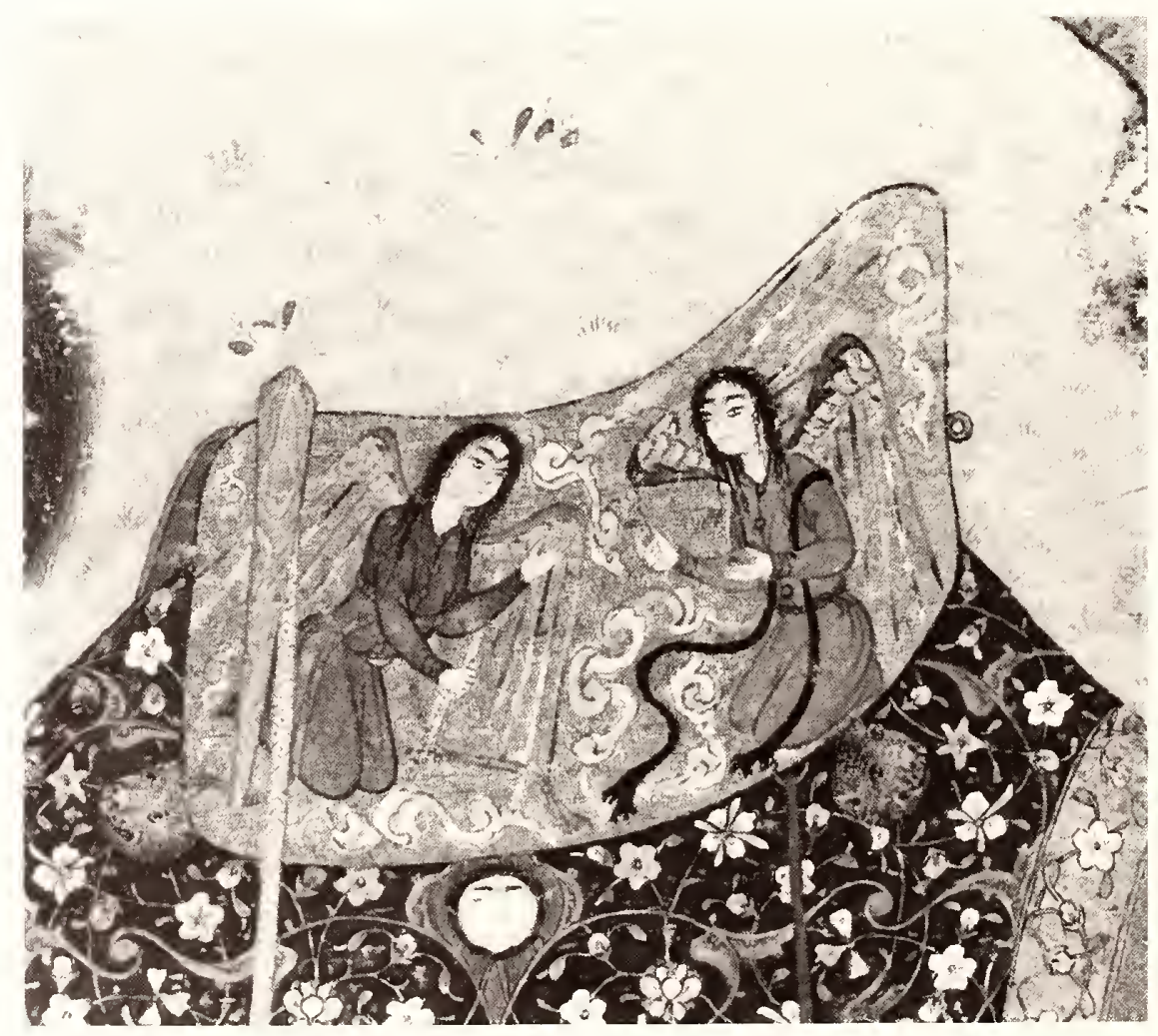


16. Prince with a Parakeet Signed by Sheykh Muhammed Iran, Safavid period, ca, 1575

Black line and gold on paper; tinted with red and green

Page: $15.7 \times 9.2 \mathrm{~cm}$. $(63 / 16 \times 35 \%$ in.)

Drawing: $14.7 \times 8.3 \mathrm{~cm}$

(5 $13 / 16 \times 31 / 4$ in.)

37.23

The drawing, mounted on heavy paper, has been cropped with red and gold borders added around the edges. The prince, set against an empty background, is shown kneeling, looking at the parakeet perched on his extended right hand. He is attired in the garments of the period with a striped turban wrapped around a soft feathery top and adorned with a single plume attached by a pin. He wears a long-sleeved shirt under a short-sleeved outfit tied at the waist with a sash; a striped handkerchief, a dagger and a penknife are tucked into the belt. In his left hand, the prince holds a pen.

The application of gold is reserved for the pin on the turban and for the metal parts of the pen. Red appears in the stripes of the handkerchief and turban as well as on the shirt, and is used in depicting the precious stones of the pin and earring. Green washes are applied to the feathery top of the turban, the sash and the parakeet.

The minute signature, barely visible below the tip of the penknife, reads: "drawing by Sheykh Muhammed." Its wording and placement are identical to a similar drawing in the Louvre ${ }^{43}$ In both works, the subjects have heavy eyelids, and the lines of the upper and lower lids project beyond the outline of the face

The same features are present in Sheykh Muhammed's only dated painting which represents a camel with its keeper, enclosed by a poem related to the subject (37.21, no. 16A). The cartouche on the top, written in red, gives the date, $964 \mathrm{Hijra}$ or 1556-57 A. D ; the panel below, also executed in red, states: "musaz'iz va mubarrir (painter and calligrapher, or writer) Sheykh Muhammed."

The artist, who was the son of a calligrapher, obviously practiced both painting and the art of fine writing. The poem was most

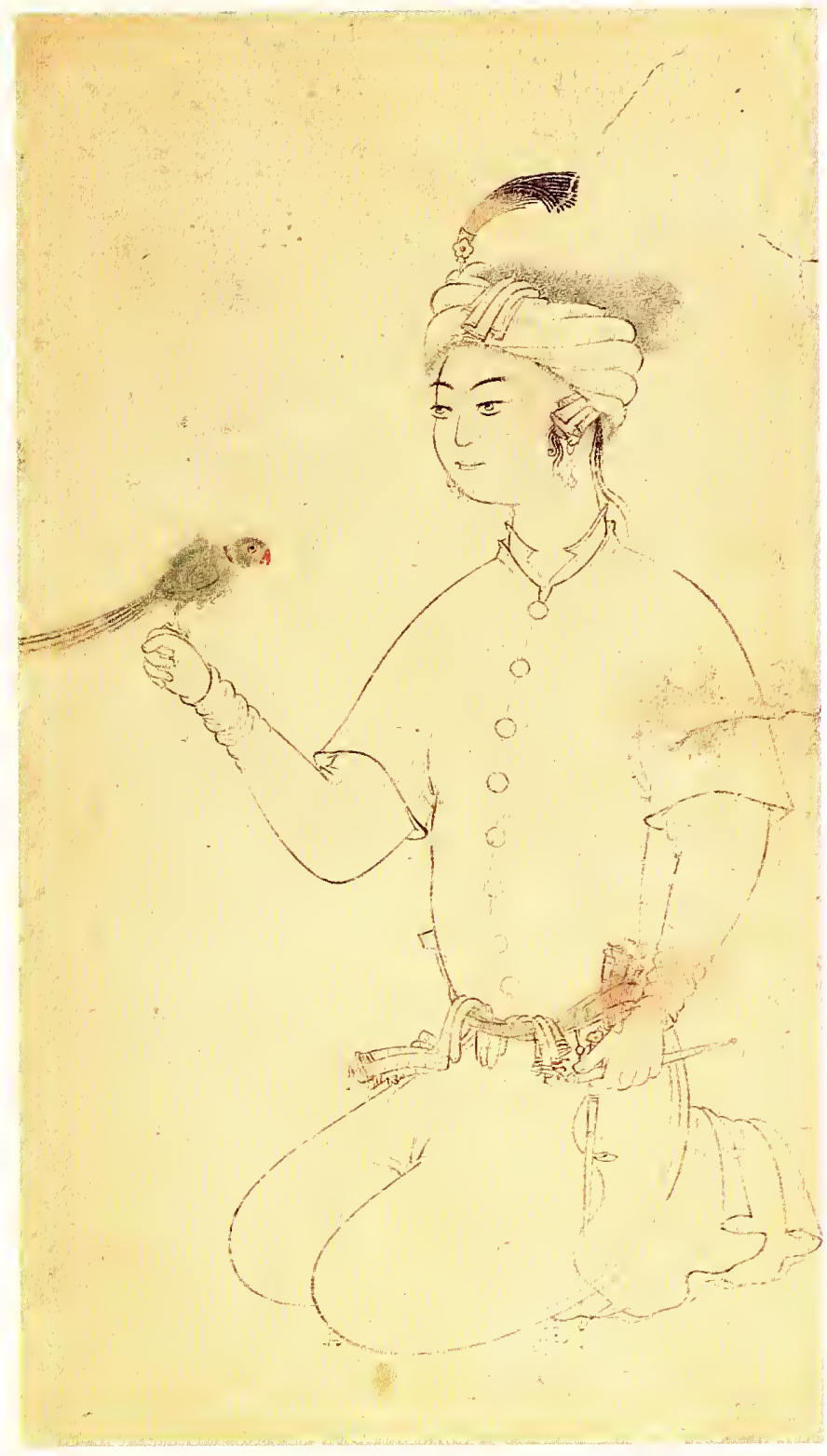

likely written by him as a companion piece to his painting. It is executed in a fine gold nastalik script and pasted on an album sheet with additional verses and stripes of illumination adorning the edges. The precise line and harmonious color employed in this painting also appear in the illustrations attributed to Sheykh Muhammed in Shah Tahmasp's Shabname and Ibrahim Mirza's Haft Atrang. ${ }^{4}$

The theme of a figure seated in a kneeling position, holding various objects such as books, flowers or wine cups, was very popular in the Safavid period and frequently occurs in single-page drawings (nos. 19, 20, 32, 36 and 51). 


\section{Drinking Party}

Iran, Safavid period, late 16th or early 17 th century

Black line on paper; tinted with red, blue and yellow

$16.3 \times 10 \mathrm{~cm} .\left(6 \% 16 \times 3^{15 / 16} \mathrm{in}.\right)$ 40.18

The drawing, cropped to the edge and pasted on cardboard, is framed by thin gold, red and black lines. It represents a group of 10 figures who are seated or standing in the foreground, gathered around a large jar, over which one of them is leaning. In the background is a rich landscape with articulated trees, shrubs and rocks filling three-fourths of the folio; on the upper right is a domed brick structure with a tiled entrance portal.

Red washes appear on the brick facade of the structure, in the bushes and rocks and on the long stoles of the figures. The large jar is decorated with blue and red motifs while the tile panel on the building has a blue floral scroll. The dome of the structure is painted yellow, suggesting a golden shell.

The group consists of an assortment of ages and types, including dervishes and youths: two of the men are bareheaded while the rest of the figures wear a variety of turbans and caps. Beardless youths intermingle with older men who have short or long beards; some hold wine cups, long-necked bottles or small rounded fruit.

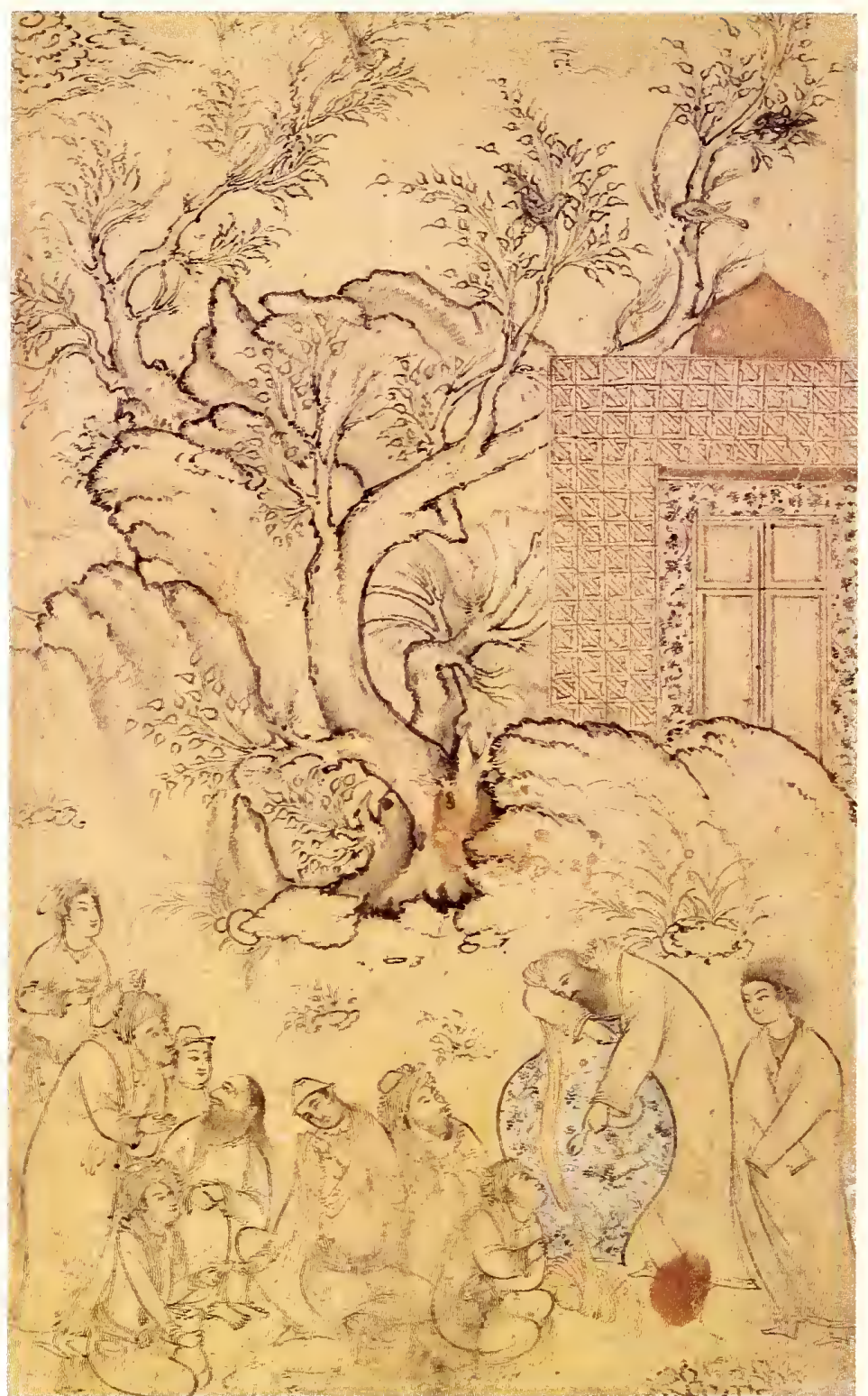




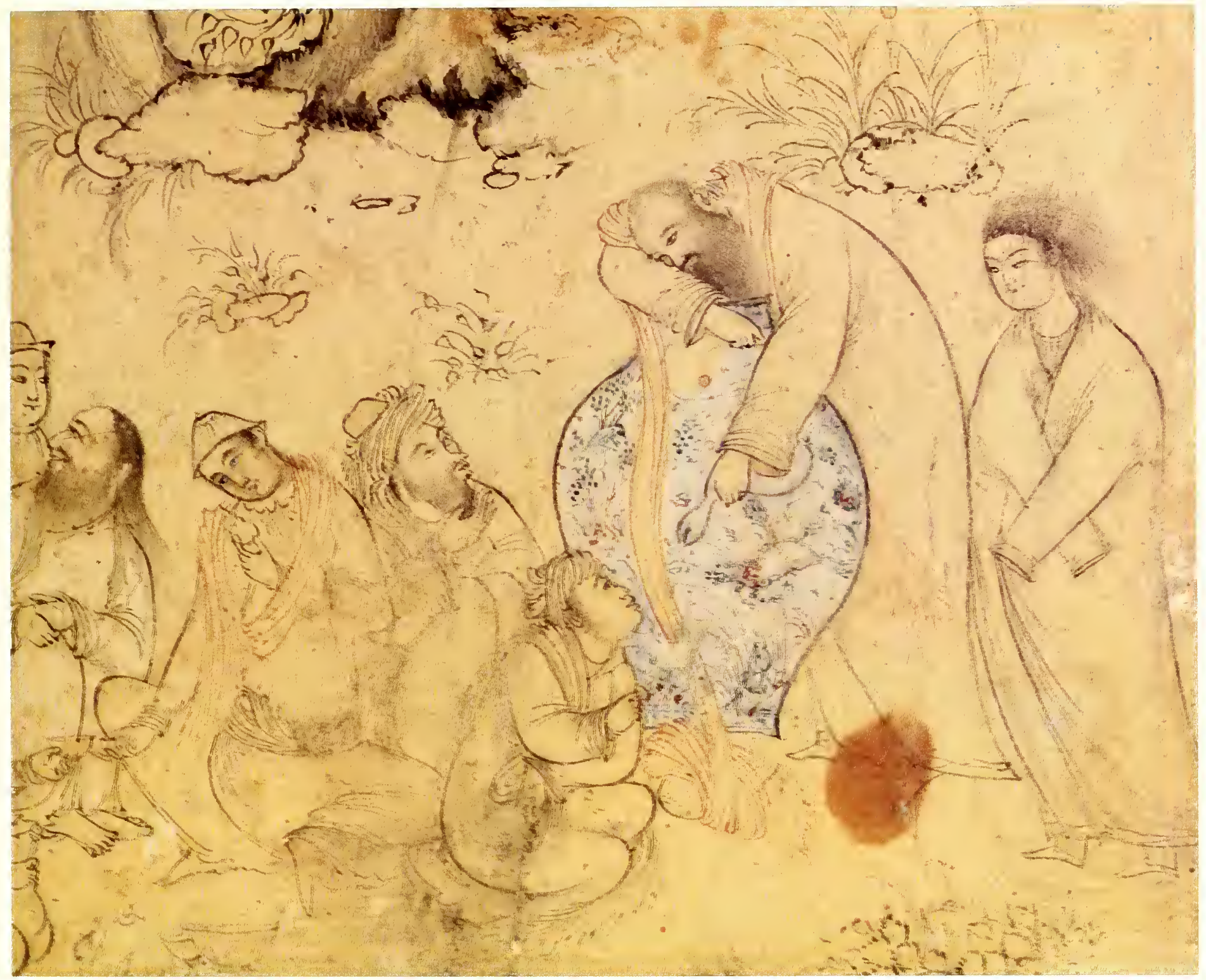

The figure leaning over the large jar is in a drunken stupor; his turban has fallen to the ground, its folds undone and dangling from his neck. He holds an unidentifiable object which looks like an animal's tail.

The ceramic jar resembles Chinese Ming dynasty wares, which were greatly in demand during this period. Shah Abbas had accumulated a large collection of Chinese porcelains which he donated in 1611 to the ancestral shrine of Sheykh Safi al-Din at Ardabil. The example in the drawing is extraordinarily large, and the red and blue decorations represent a rare type. It is possible that cer- tain artistic liberties were taken in both the size and glaze of the immense jar, so as to exaggerate the amount of wine consumed by the party

Drinking figures, alone or in groups, were frequently portrayed on single-page paintings and drawings by the Isfahan artists, representing the most popular pastime of the members of the court and the public (nos. 19, 20, $23,30-32$ and 36). This group, a mixture of layman, sufis and dervishes, participates in a common activity which takes place in the vicinity of one of the holy shrines scattered throughout Iran. 
18. Musicians and Dancers Attributed to Mirza Muhammed al-Huseyni

Iran, Safavid period, dated 1613

Black line and gold on paper; tinted with red, blue, green and yellow

Page: $36 \times 24.2 \mathrm{~cm}$

$(141 / 8 \times 91 / 2$ in.)

Drawing: $17.3 \times 9.9 \mathrm{~cm}$

$(63 / 4 \times 37 / 8$ in $)$

07.157

The tinted drawing of five figures- two of them dressed in goatskins, dancing to the music provided by a quartet - was originally a part of an album. It is mounted on a pale green sheet adorned with gold marginal decorations depicting flying geese, roosters, butterflies and ducks in a landscape. A gold floral scroll frames the drawing with additional gold, red and green lines encircling the border

The back of the sheet has similar marginal drawings with rabbits deer, foxes and butterflies surrounding four panels of text. Each panel contains a couplet written in white nastalik on brown or blue ground. The date $1032 \mathrm{Hijra}$ or 1623 A.D., appears in the last panel

The drawing depicts the dancers and musicians performing in a landscape with a large tree and several different types of bushes rising above the rocks in the background. The ground is sprinkled with small rocks, clusters of grass and floral sprays. On the upper right, two men with long tapered hats surmounted by animal tails dance in exaggerated poses, swinging their arms and jumping on one foot. Below is another dancer in the same pose, his long sleeves dangling over his arms. He is flanked by two figures attired in goatskins and play ing clappers. The four musicians in the foreground perform with a tambourine, panpipes and two drums.

The scene is executed in black line with gold applied sparingly to the metal parts of the hats, musical instruments and horns of the costumes. Soft washes of red, blue, green and yellow appear in the landscape and on the garments.

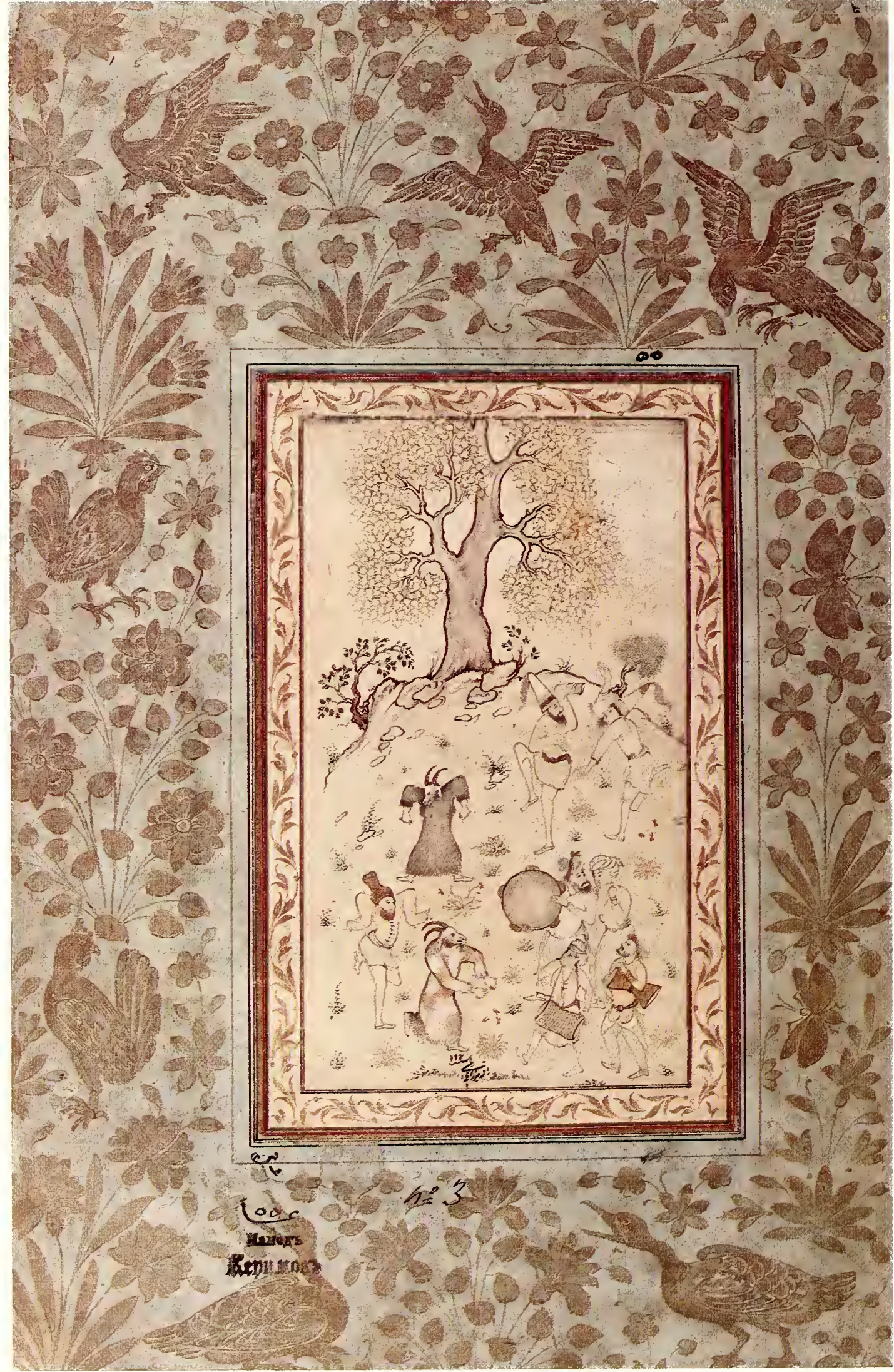


An inscription, added at a later period, states that the drawing was made by Mirza Muhammed al-Huseyni in $1012 \mathrm{Hijra}$, that is, 1613 A.D. The name of this artist is not found on any of the paintings or drawings of the period, nor is it recorded in the lists of calligraphers and painters pertaining to the 17 th century.

Dancing figures wearing animal masks or skins appear in Islamic art, particularly during the Safavid period, and represent itinerant entertainers. ${ }^{45}$ The composition and the grouping of figures seen in this drawing are based on an example in Leningrad which bears the signature of Muhammedi; another version of the same scene, also with Muhammedi's name, is in London, while a third is in a private collection. ${ }^{46}$

All four drawings employ the same group of musicians, the dancing pair wearing tall hats and the two men in animal skins. In the Leningrad example, the single dancer with dangling sleeves is placed on the top of the folio and another figure attired in goatskin is added to the center of the scene; in the London copy, the single dancer is omitted and one of the men clad in an animal skin is reversed; in the third version, there is an additional musician as well as another dancer. The Freer drawing is closer in composition to the Leningrad example, but the dancers are organized in a more structured manner, forming a semicircle leading to the musicians; the setting is more detailed with elaborate elements filling the landscape.

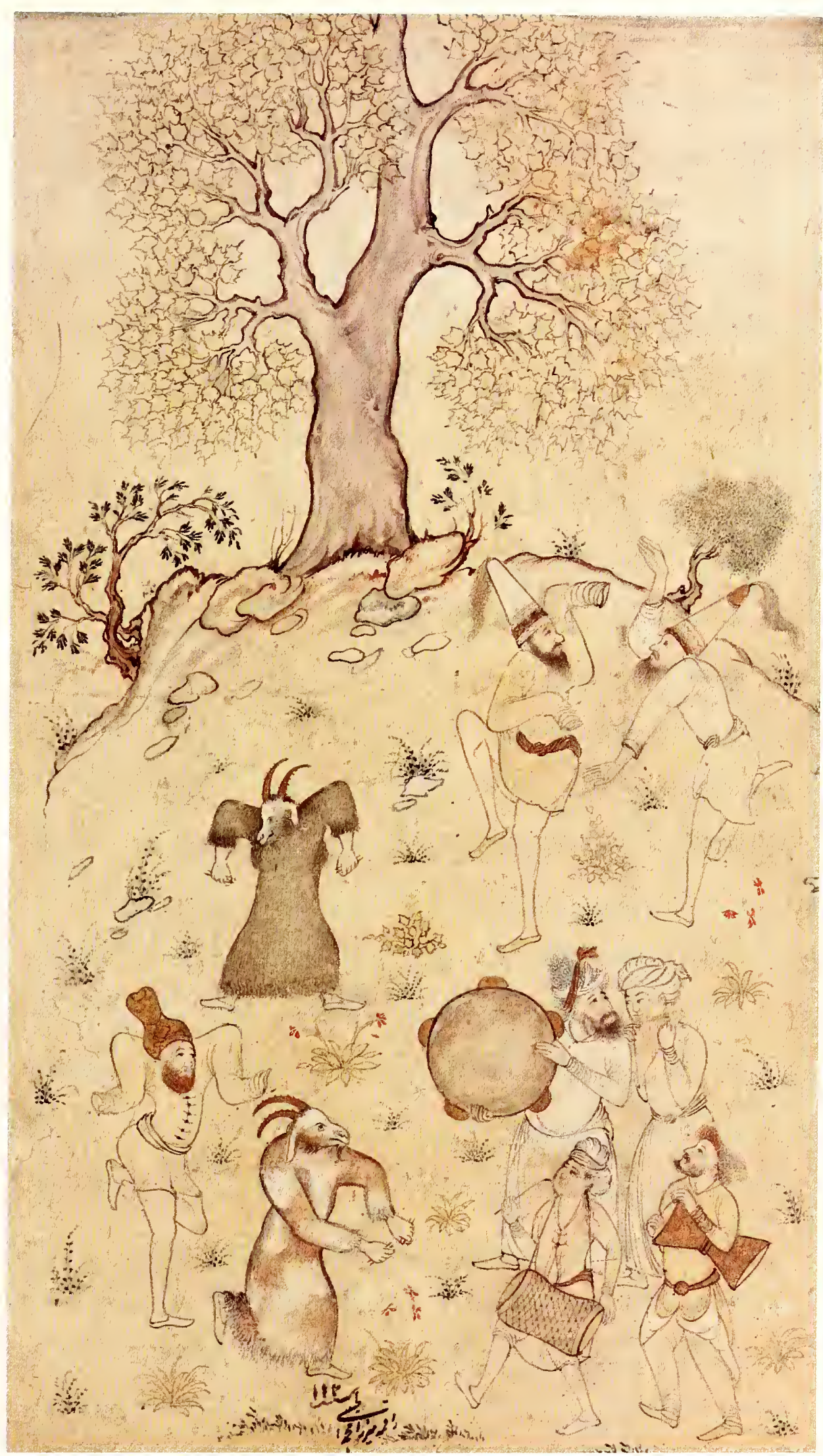


19. Youth with a Wine Cup Signed by Riza-i Abbasi Iran, Safavid period, early 17 th century

Black line and gold on paper; tinted with magenta, blue and green

Page: $29.5 \times 18.5 \mathrm{~cm}$. (I $15 / 8 \times 71 / 4$ in.)

Drawing: $13.5 \times 8.9 \mathrm{~cm}$. $\left(5 \frac{1}{16} \times 31 / 2\right.$ in. $)$

28.10

The drawing of a kneeling youth offering a cup of wine is pasted on an album leaf mounted on cardboard. The leaf, tinted beige and decorated with gold, depicts a landscape with pairs of predators and their prey- such as a lion and gazelle, fox and goat and lion and hare. The animals appear on the top, right and bottom portions of the folio; the left margin has been trimmed to the edge of the drawing. The drawing is framed by a series of gold, blue, green and white lines around which is a border of gold-speckled beige paper, enclosed by additional gold lines.

The youth wears a gold embroidered magenta cap with a blue feathery top; his sash is striped in green, blue and gold while a gold collar and a series of gold but tons adorn his garment. The landscape elements - a willowy tree and clusters of grass and flowers-are rendered in gold, as are the shallow cup in his extended hand and the tall-necked wine bottle on the lower left. The signature, placed along the lower edge, reads: "drawing by Riza-i Abbasi."

The figure is placed firmly on the ground, kneeling on a piece of cloth. Arrested movement of this type is rare among the singlefigure representations by the artist.

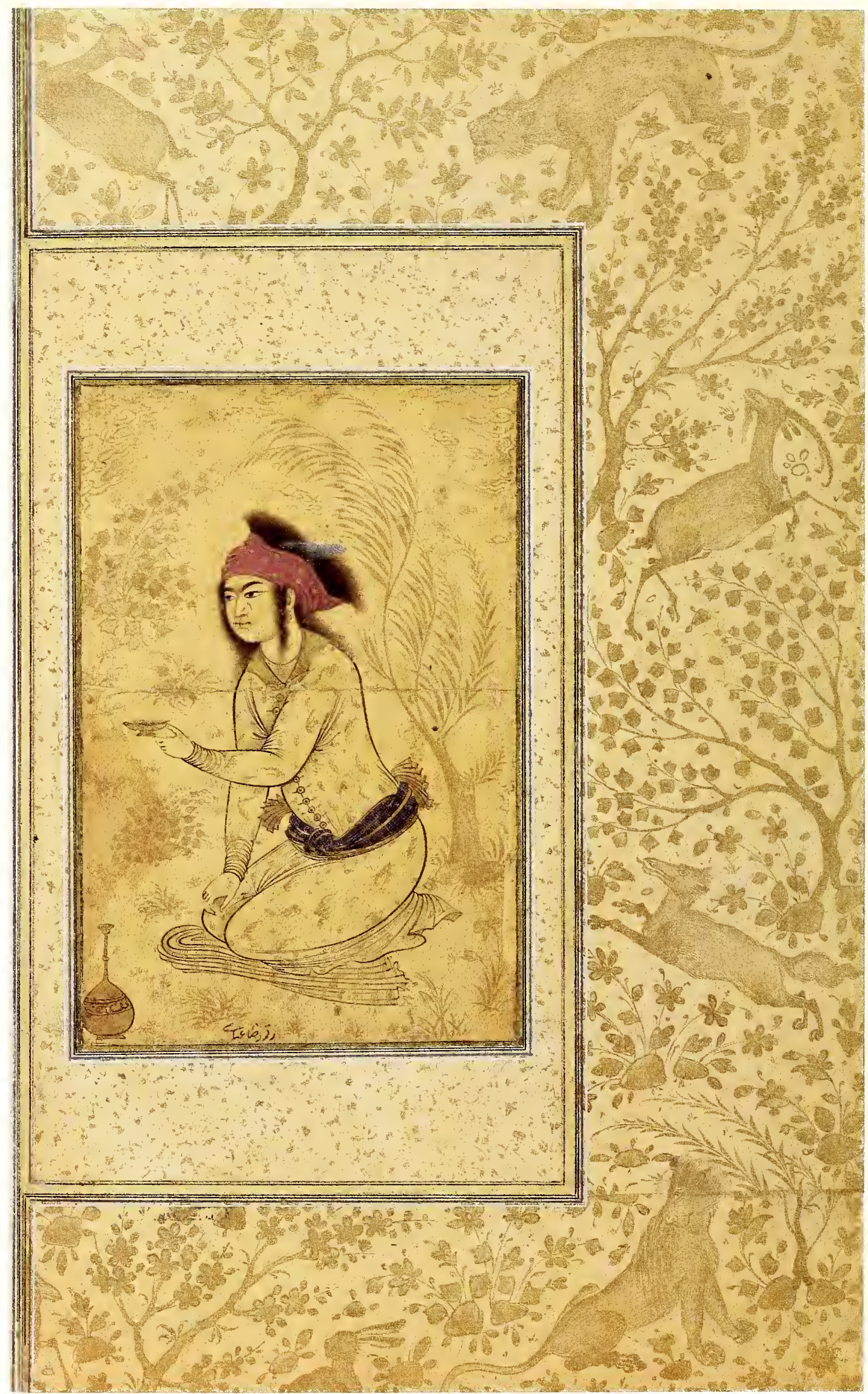


Riza's single-page album paintings often portray aloof figures who seem to possess dream-like or other-worldly qualities. The same controlled line, soft modeling and drapery folds with crisp and agitated edges also appear in the two signed paintings by Riza owned by the Freer Gallery of Art (32.9 and 54.24, nos. 19A and 19B). The painting which portrays a young woman holding a fan is signed: "the work of Aka Riza" (no. 19A). The library seal of Shah Abbas with the date 1587 , the year of his accession to the Safavid throne, appears on the portrait and helps to date the painting. This example, executed shortly after Riza joined the court of Shah Abbas, is probably one of his earliest works. The other painting represents a reclining nude wrapped in a diaphanous sheet; she has fallen asleep or is daydreaming at the edge of the water while reading a book of verses (no. 19B). The signature, written above her neatly placed slippers, reads: "the work of Riza." Both paintings, formerly in imperial albums, are mounted on folios adorned with illuminated bands or verses of poetry. Both the reclining nude and the portrait of the woman holding a fan, were made during the last two decades of the 16th century and predate the drawing of the kneeling youth with a wine cup by several years.

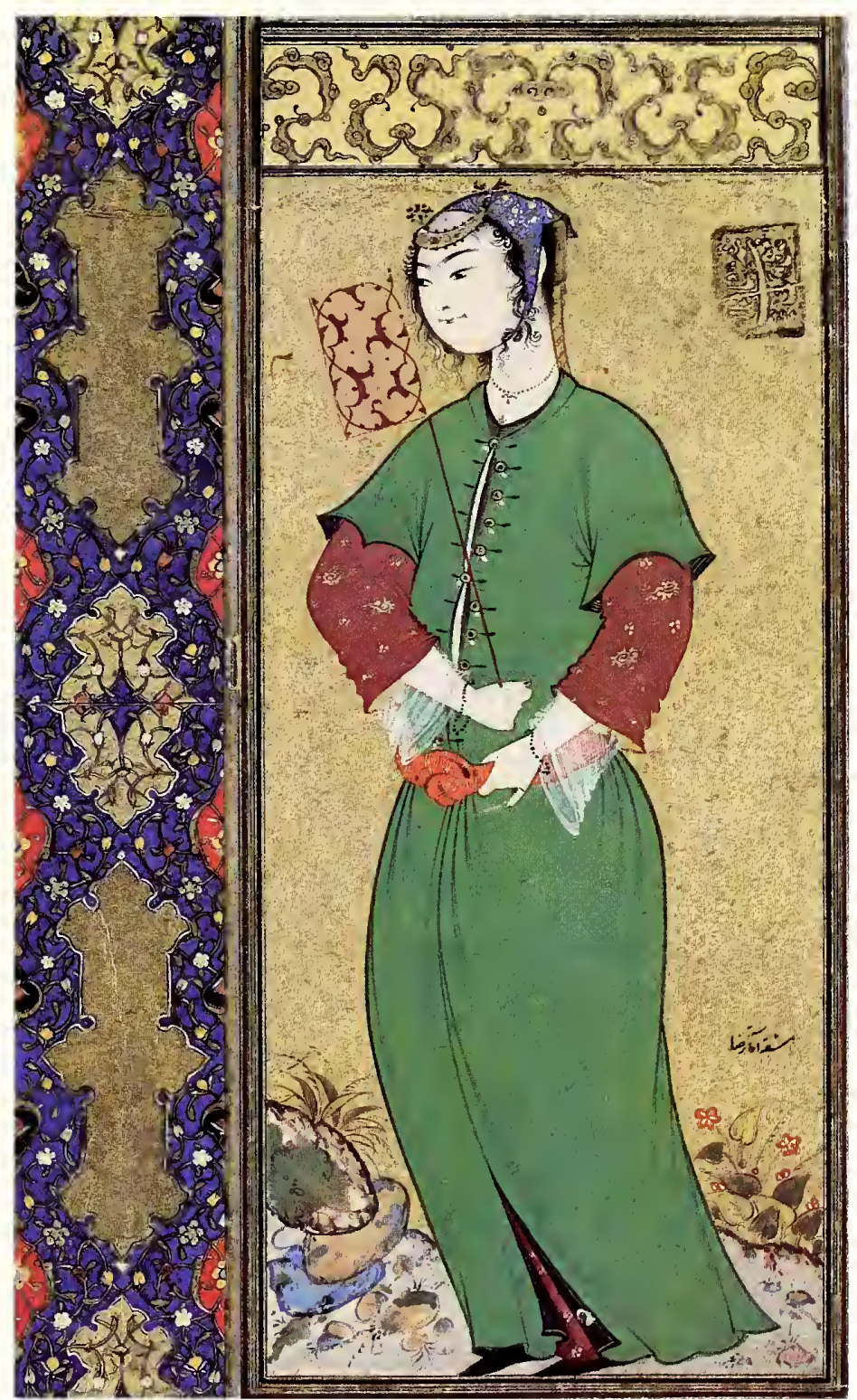

19A. Woman with a Fan

Signed by Aka Riza

Iran, Safavid period, ca. 1590

(32.9) 
Riza's signatures have caused some confusion among scholars, since he uses "Riza," "Aka Riza" and "Riza-i Abbasi." It was generally betieved that during the earlier part of his career he preferred "Rizat," then changed to "Aka Riza" and finally, in homage to his patron, added "Abbasi" to his name. There has also been some discussion as to whethet all three signatures actually belonged to the same artist. However, judging from the dated examples of Riza's work in the Freer album, it appears that he used different versions of his name without any chronological or logical sequence. For instance, both "Riza-i Abbasi" and "Aka Riza" are used on two examples made in 1639 (nos. 31 and 33 ).

Generally Riza's paintings bear the phrase mashaka-bu, "painted by," and his drawings are inscribed rakimu-bu, "drawn (or sketched) by." This is the case with the tinted drawing of the youth with a wine cup as well as with other examples included in the album (nos. 27-33). On these drawings he frequently uses the phrase rakm-i kamina, "drawn by the humble servant," which precedes his name.

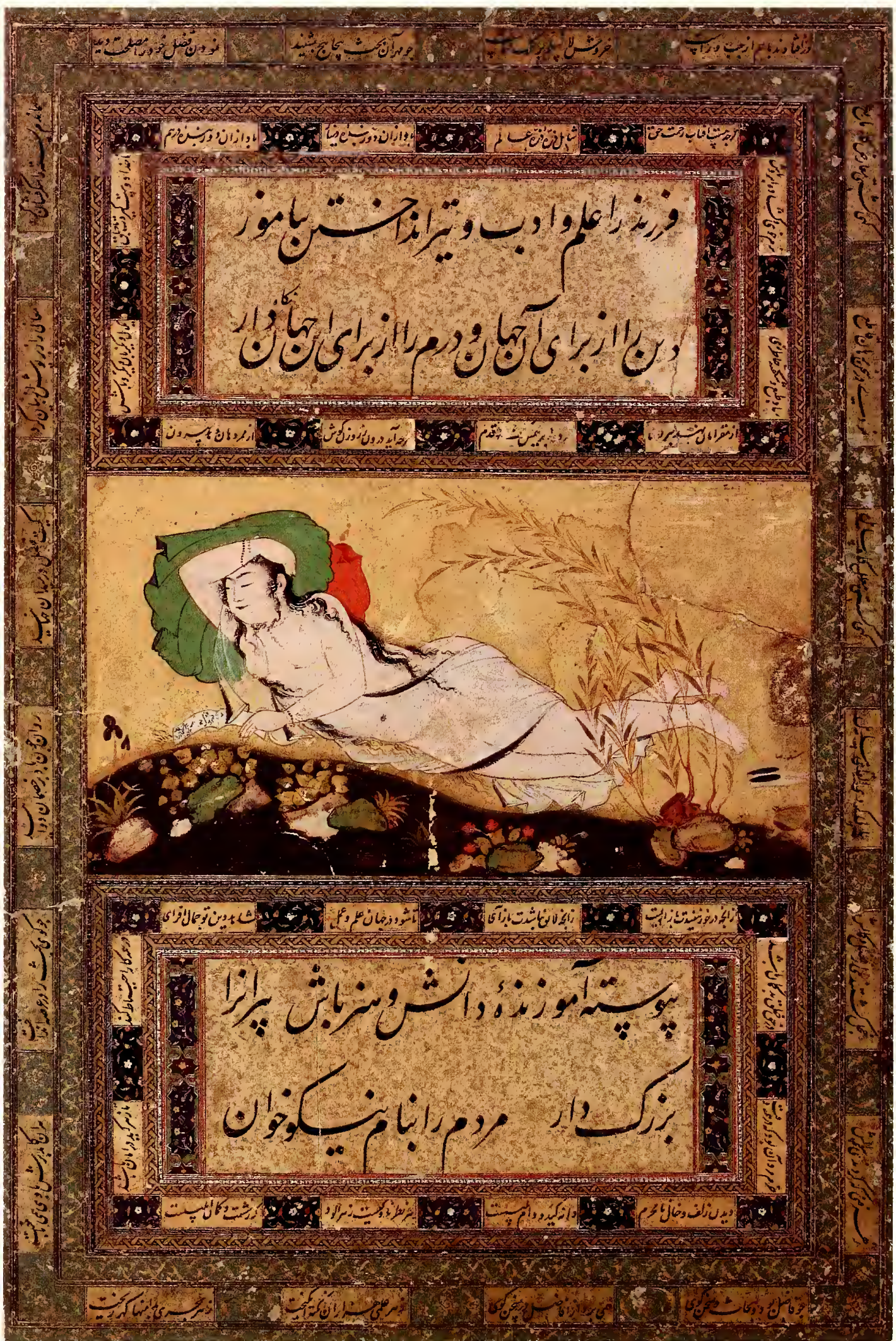

19B. Reclining Nude

Signed by Riza

Iran, Safavid period, ca. 1590

(54.24) 
20. Man with a Wine Cup

Signed by an anonymous follower of Riza

Iran, Safavid period, mid-17th century

Black line and gold on paper; tinted with blue

Page: $36.5 \times 24 \mathrm{~cm}$ ( $143 / 8 \times 9^{7 / 16}$ in.)

Drawing: $11.4 \times 8 \mathrm{~cm}$. ( $41 \frac{1}{2} \times 31 / 16$ in.)

07.2

The drawing of a kneeling man is pasted on an album sheet which has a poem of four lines enhanced by delicate illumination on the reverse. Written on an angle in a fine nastalik, the verses are signed by Hasan Shamlu. ${ }^{47}$

Each side of the folio is decorated with gold marginal drawings on a pink ground. The reverse depicts a hawk hunting a goose on the top while a fox chases a rabbit below; willowy trees and a hawk adorn the sides.

The margins around the drawing are filled with clusters of carnations, tulips, hyacinths, irises and primroses with butterflies and insects hovering around them. Blue and gold lines are drawn around a frame of scrolling gold leaves which enclose the drawing and the four lines of poetry.

The drawing, executed on brown paper, shows a bearded man kneeling on the ground holding a wine bottle and a cup with several pears placed in front. Gold is applied to the cup as well as to the clouds and shrubs in the background. The only other color in the scene is blue which appears in the lining of the man's sleeve.

The inscription, placed above the cup, is interpreted as: "copied by the slave (or follower) of Riza-i Abbasi." The figure represented appears to be a dervish, wearing a 12-gored cap under his turban and a long stole wrapped around his shoulders. The poetry on the top and bottom of the portrait refers to a sheykh who was once averse to the pleasures of wine but finally succumbed and became boisterously drunk. Album folios were often composed with paintings and poetry which expressed similar sentiments, providing pictorial and verbal versions of the same theme.

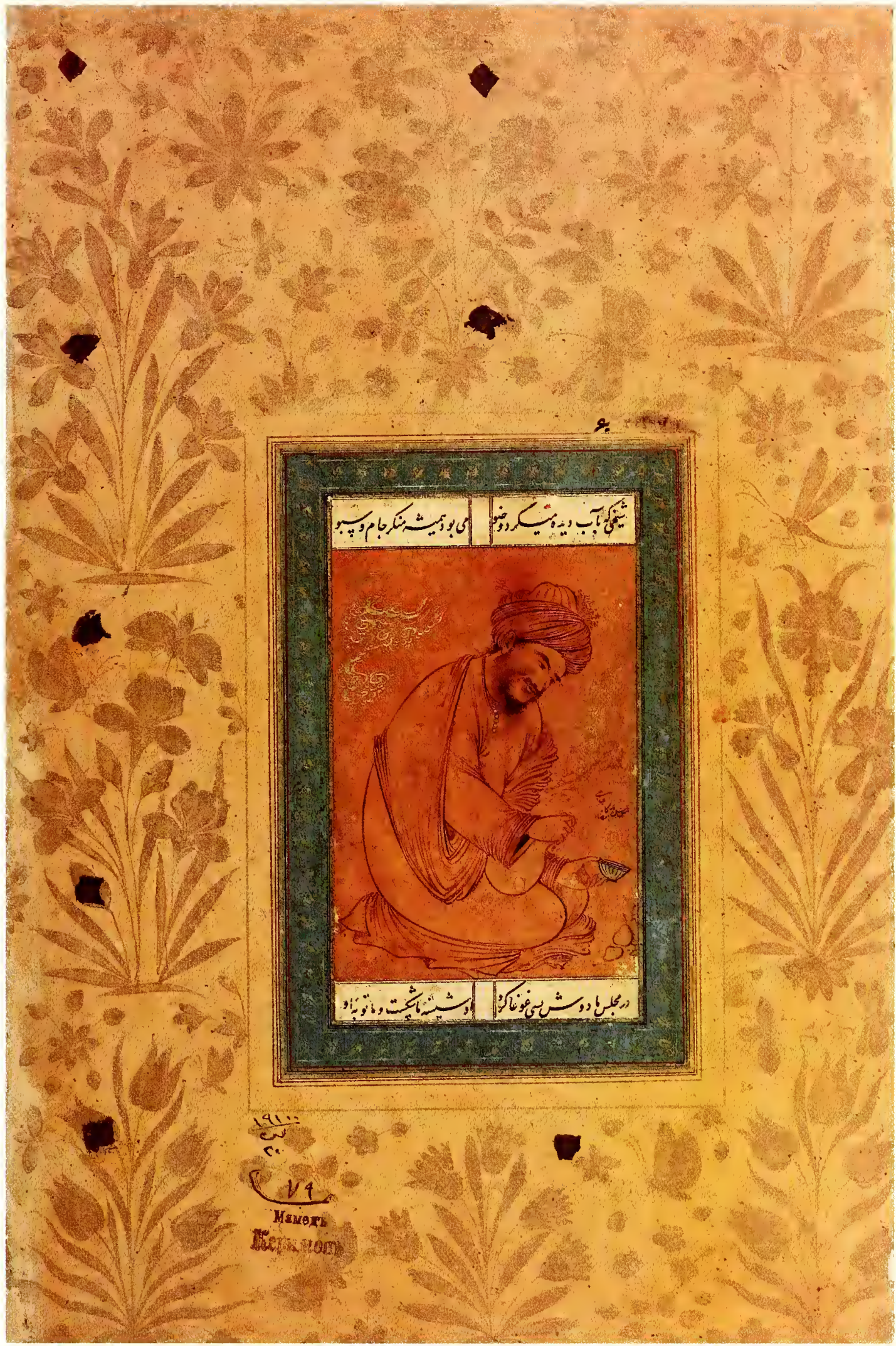


21. Old Man in a Landscape Iran, Safavid period, early 17 th century

Black line on paper; tinted with red

Page: $24.4 \times 15.8 \mathrm{~cm}$. (91/8 $\times 61 / 4$ in.)

Drawing: $11.6 \times 6.8 \mathrm{~cm}$. ( $41 / 2 \times 25 / 8$ in.)

67.7

This drawing, surrounded by a gold-flecked blue sheet and enclosed by several gold, blue and white lines, is mounted on blank cardboard. The figure is drawn in sharp and swiftly executed black lines while the landscape elements in the background are rendered with softer brush strokes. Touches of red appear only on the face of the old man, modeling his cheeks and defining his lips.

The figure is represented in an exaggerated position, leaning back against a tree trunk while extending his right hand. It is possible that this drawing is unfinished and the personage was meant to hold an object in his hand.

The technique and style of execution are very close to those of Riza; this scene was either sketched by him or made by one of his close followers.

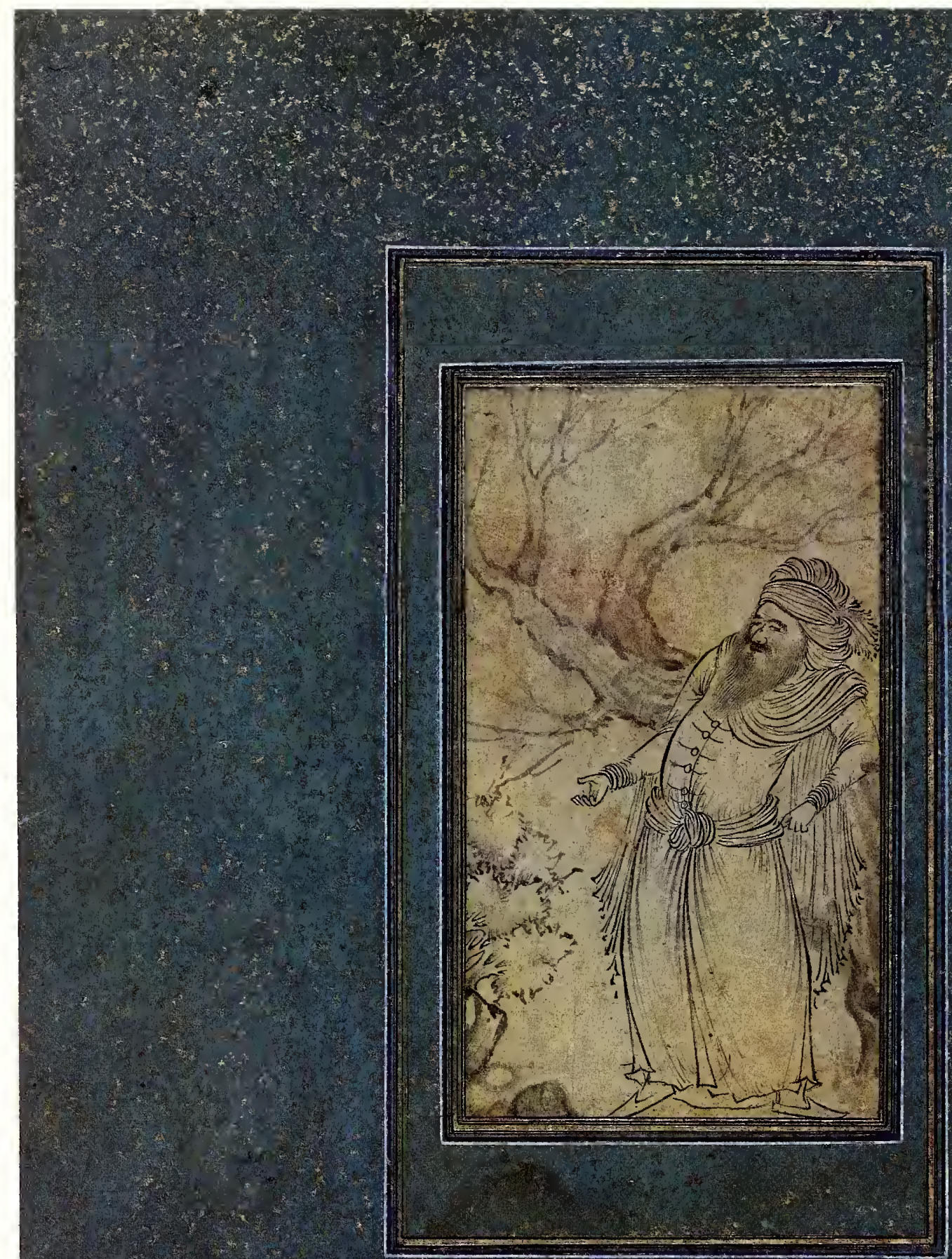


22. 'Two Youths Embracing

Iran, Safavid period, mid-17th century

Black line on paper; tinted with red, blue, green and white

Page: $33.4 \times 22.9 \mathrm{~cm}$.

(131/8 $\times 9$ in)

Drawing: $22.9 \times 13.9 \mathrm{~cm}$

$(9 \times 51 / 2$ in.)

54.28

The back of this album leaf contains an illuminated quatrain written in nastalik by Muhammed Huseyin al-Tabrizi, the renowned calligrapher who was placed in charge of the inscriptions on government buildings and gates during the reign of Ismail II ${ }^{48} \mathrm{He}$ is said to have taught calligraphy to Riza.

The tinted drawing is enclosed by thin red, blue, green and gold lines, with a wide yellow and red border added at a later date. It depicts two embracing youths, a subject with erotic implication not uncommon for the period. The arms of the youths are around each other, their embrace accentuated by the engulfing stoles The intertwined branches of the tree in the background, the two different types of plants and a pair of bottles in the foreground can be interpreted as subtle references to the relationship of the youths

A touch of red is added to the lips of the figure on the left; blue is applied to the lining of the garments, one of the wide sashes and the scalloped collar of the tallnecked bottle; green appears on the stole of the youth on the right. The use of white- on the headdress, shoes, stripes of the sash and the knife-is rather unusual and rarely occurs on the other drawings of the period. The cup held by one of the figures and the tall-necked bottle in the foreground are also rendered in white, suggesting that they are porcelain or high-fired wares.

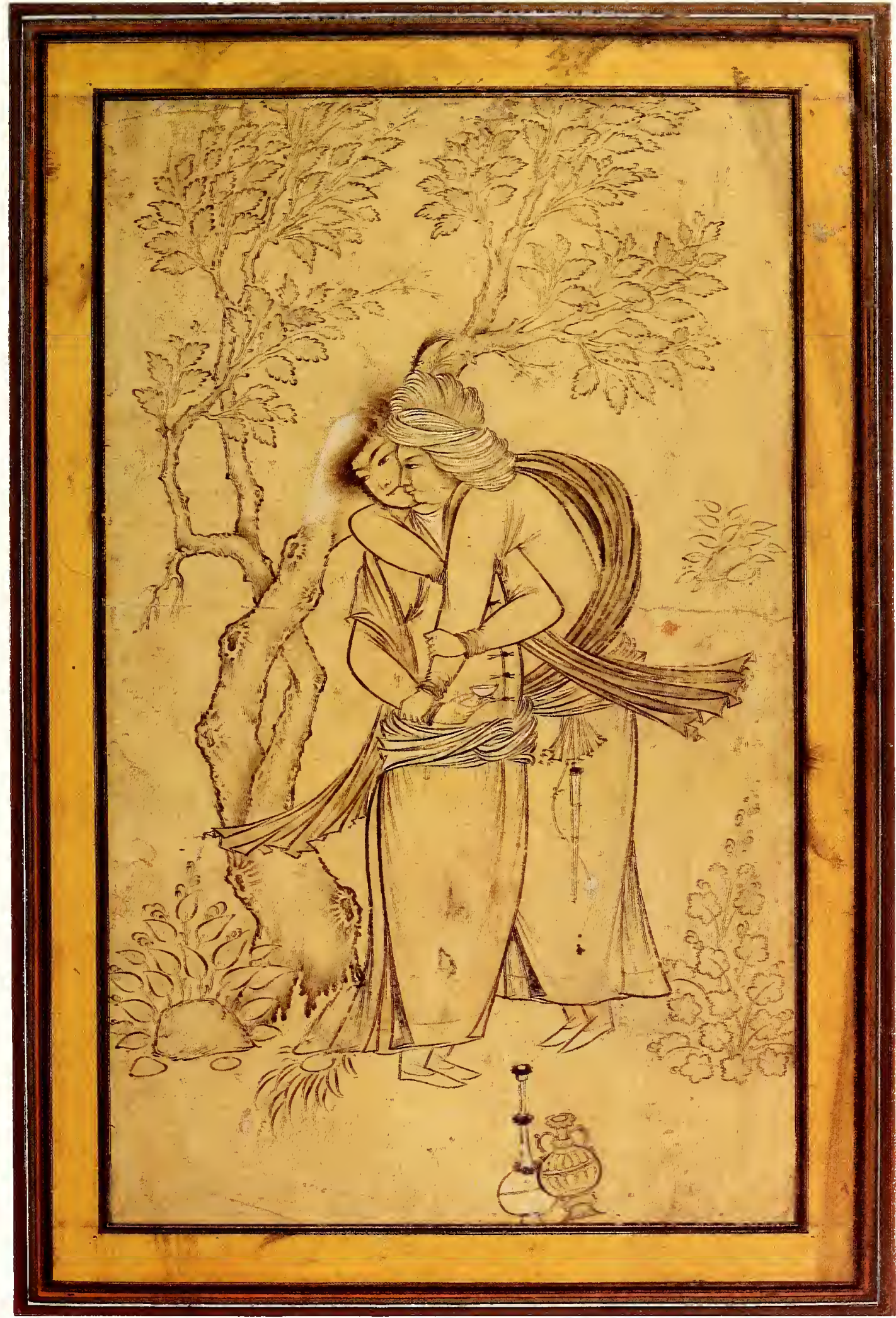




\section{Prince Seated on a Rock} Iran, Safavid period, 17 th century

Black line and gold on paper Page: $42 \times 28.8 \mathrm{~cm}$.

( $161 / 2 \times 113 / 8$ in.)

Drawing: $21 \times 11.6 \mathrm{~cm}$. $(81 / 4 \times 4 \%$ in. $)$

68.11

One side of this album leaf represents a youthful prince seated on a rock while the other contains a Mughal tinted drawing depicting lovers. The leaf is crudely designed with damaged strips of calligraphy pasted around a garish red and yellow border.

The prince is attired in the garments of Shah Tahmasp's reign with a tapered turban wound around a thin and tall cap. Two different types of feathers adorning the headdress and the richly embroidered coat suggest that the subject is of noble birth. The casual manner in which the prince sits-crossing his right leg over the other after having removed one shoe, his coat partially off with only one sleeve over his shoulder-also points to midI6th century traditions, indicating that the drawing was copied from an earlier model. It is possible that the subject represents Shah Tahmasp himself.

The figure holds a wine bottle and cup, while watching an entertainer dressed in goatskin who dances and plays clappers. There is a tray of fruit in the background.

Gold is used to depict the landscape elements, and appears on the coat and such metallic portions of the figure's costume as the buttons, belt and jewelry on the turban. The vessels - wine bottle, cup and tray-are also rendered in gold.

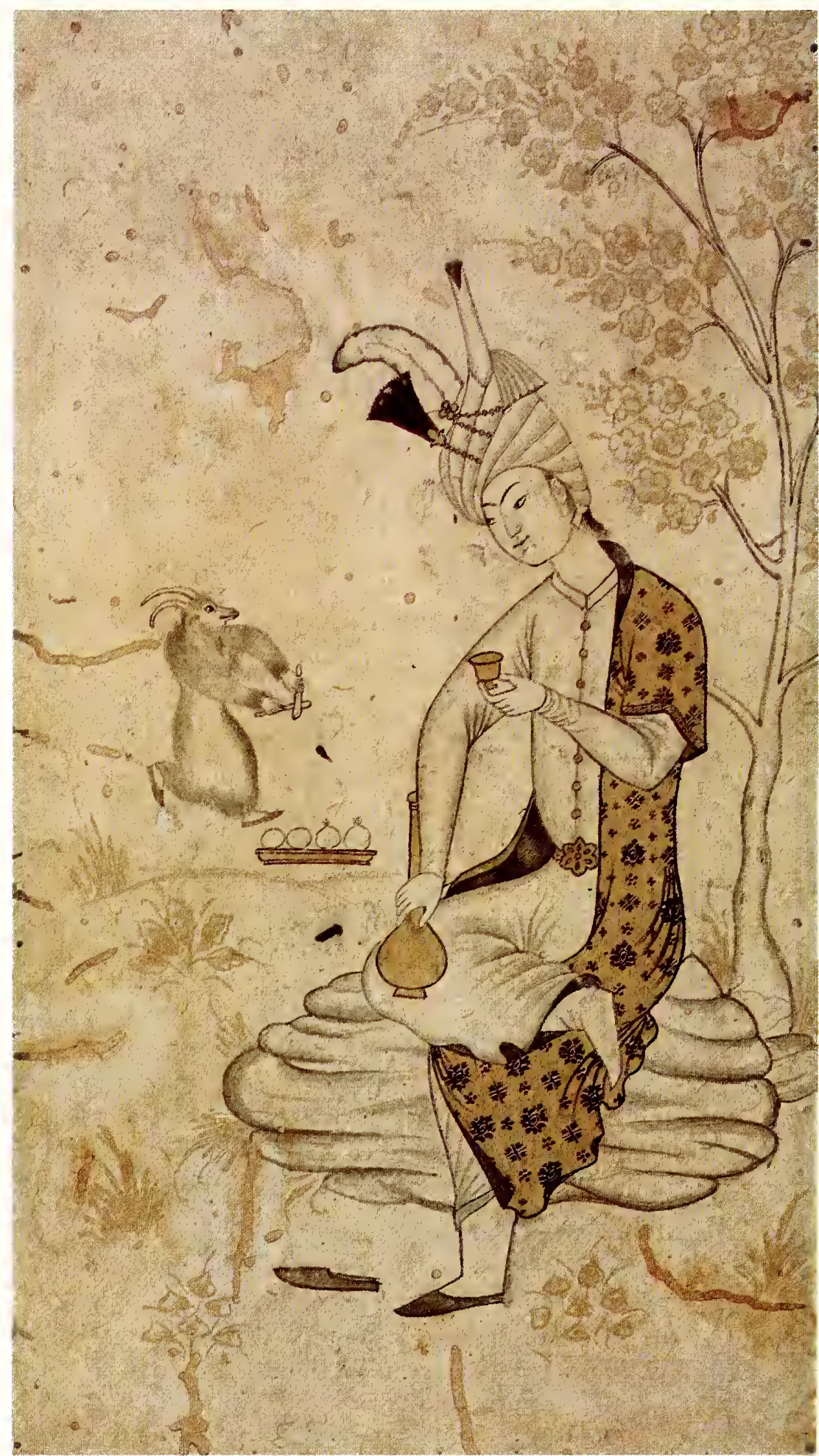


24. Woman with a Large Jar Signed by Muhammed Muhsin Iran, Safavid period, dated 1649

Black line and gold on paper; tinted with red and blue

Page: $33 \times 21.7 \mathrm{~cm}$.

( $13 \times 8 \%$ in in)

Drawing $21.1 \times 10.1 \mathrm{~cm}$ $(85 / 16 \times 4$ in. $)$

12.99

The margins of this folio are decorated with arabesques containing animal heads and cartouches stenciled in red on a blue ground. The leaf, mounted on blank cardboard, contains two gold-flecked stripes placed on either side of the drawing.

The illustration represents a young woman carrying a large single-handled jar, swaying elegantly under its weight. An elaborately knotted sash encircles her waist while a long stole wrapped around her torso ripples behind. Her dress is embroidered with gold cloud motifs. Gold is also used on an ornament hanging on her forehead and in the tree. clouds, clusters of grass and blossoms adorning the background. Touches of red appear in the woman's beaded necklace, shoes and undergarment, while blue is added to the lining and buttons of her dress and to the stripes in her sash. The jar, inspired by Chinese porcelains, is decorated with a blue branch around which a pair of red-winged birds fly. The scalloped ring around the neck and the fancy handle suggest that the artist took certain liberties in representing a Ming dynasty ware (see also no. 17)

The inscription on the upper right of the composition reads: "drawing by Muhammed Muhsin," below which is the date 1059 Hijra, or 1649 A. D. An identical drawing, bearing the same date, was recently sold in London. ${ }^{49} \mathrm{It}$ seems remarkable that the artist executed two versions of the scene in the same year. Drawings by this artist are extremely rare; the only other known example is included in the exhibition (no. 25)

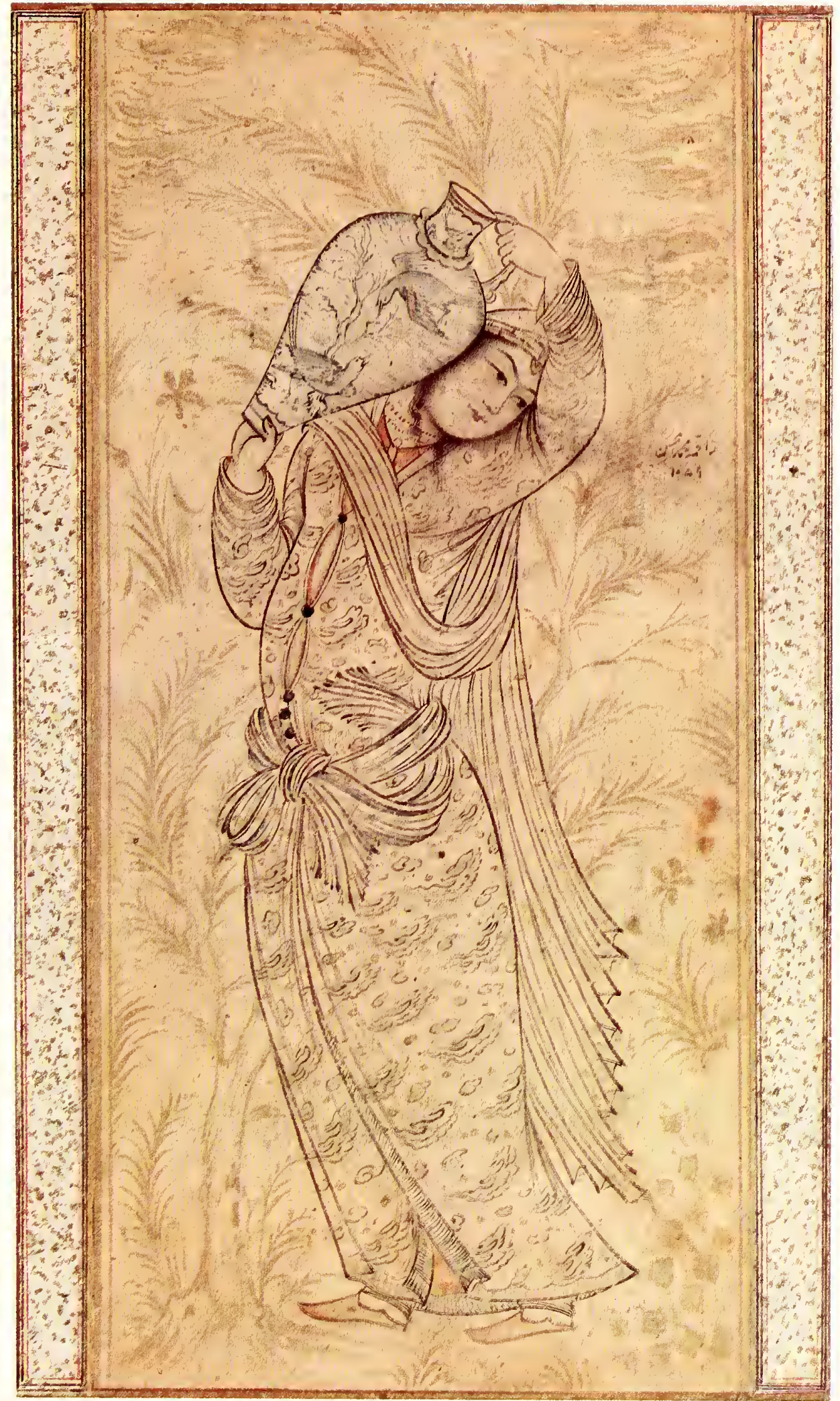


25. Dervish and His Disciple Signed by Muhammed Muhsin Iran, Safavid period, mid-17th century

Black line on paper; tinted with red, blue and yellow

Page: $19.3 \times 12 \mathrm{~cm}$

$$
\text { (75/8 } \times 411 / 16 \text { in.) }
$$

Drawing: $16.8 \times 9.3 \mathrm{~cm}$.

$$
(65 / 8 \times 35 / 8 \text { in.) }
$$

47.23

The second drawing bearing the name of Muhammed Muhsin is mounted on blank cardboard and framed with pink and beige panels adorned with gold motifs. The finely drawn scene represents a bearded dervish seated at the foot of a tree, smoking a water pipe held by a youthful disciple. A body of water ripples in the foreground, its shore lined with rocks and vegetation. The luxuriously foliated tree gracefully extends to the upper portion of the folio with decorative clouds and birds filling the background.

Washes of red appear in the tree trunk, the disciple's cap, the water pipe, and on the sheet below the dervish; blue is used on the youth's garment and in the dervish's hat, yellow appears on the disciple's stole and scarf, around his master's hat and in the leaves of the tree.

The inscription, placed in the center of the drawing, next to the tree, reads "Muhammed Muhsin." Although there is some difference in the style of writing of this signature as compared with that on the previous example, the execution of the clouds and birds and of the folds and ripples in the stoles worn by the figures in both works support the attribution to Muhammed Muhsin

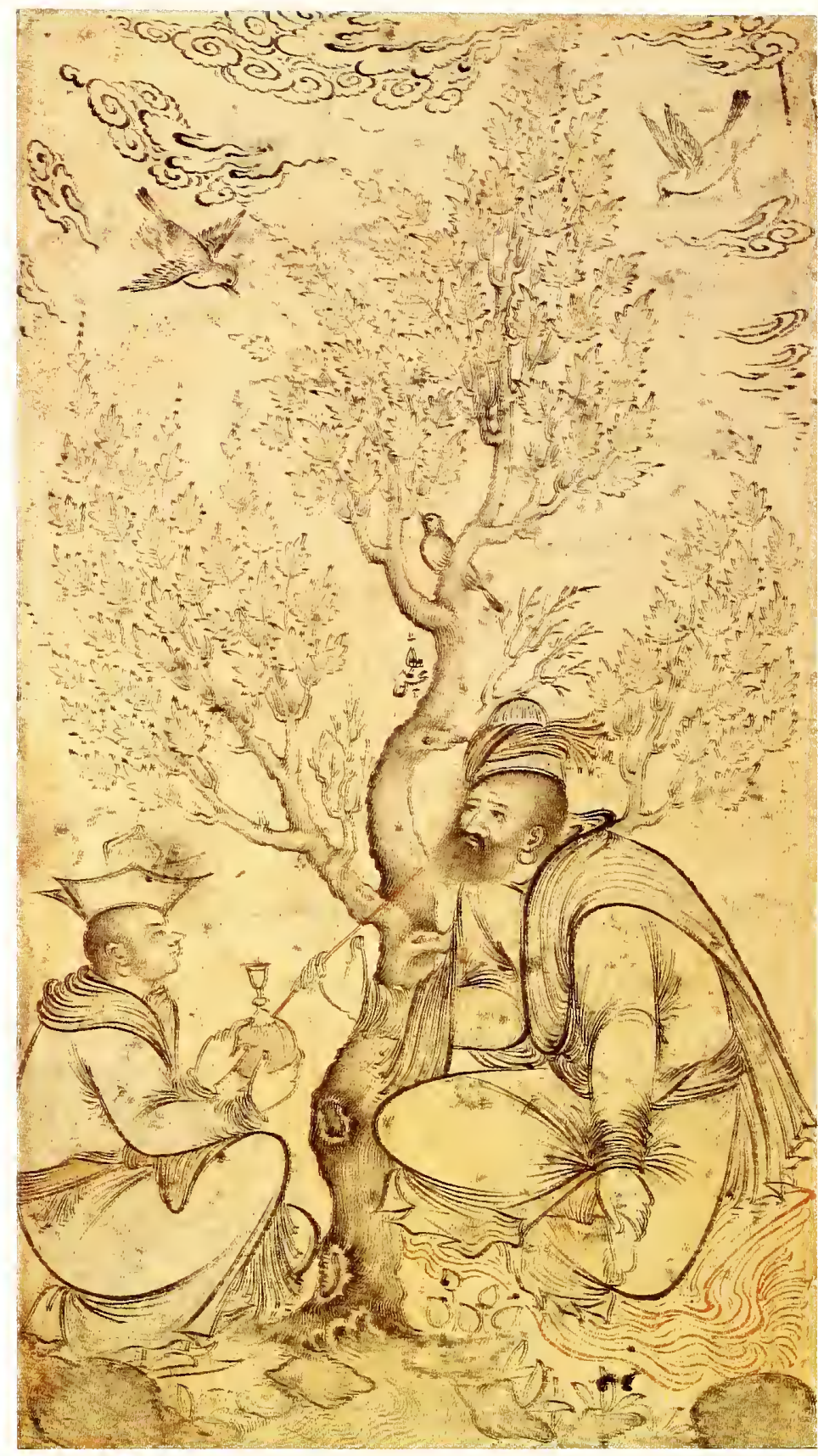


26. Monkey Riding a Lion Signed by Muin Musavvir Iran, Safavid period, dated 1672

Black line on paper, tinted with red and yellow

Page: $22.5 \times 16.2 \mathrm{~cm}$. ( $87 / 8 \times 63 / 8$ in.)

Drawing: $13.5 \times 7 \mathrm{~cm}$. $(53 / 8 \times 23 / 4$ in. $)$ 66.13

Muin Musavvir, the most talented follower of Riza, was as prolific a painter as his master. His drawings reveal an excellent control of line and an interest in original subject matter. This example, which represents a trained monkey riding a tame lion, is mounted on a blank cardboard with unattractive red and blue borders added at a later date

The monkey wears a pointed yellow cap and carries a banner and a shield tinted red. Red also appears on the tongue of the lion strolling in the landscape. The lengthy inscription placed on an angle across the top of the drawing reads: "on Wednesday, the 4th of the month of Shavval, in the propitious year 1082 (February 3, 1672), this was drawn for an album, Muin Musavvir (that is, Muin, the painter) drew it, may God forgive him, may it be auspicious." The wording and precise dating are consistent with the inscriptions found on contemporary drawings (see nos. 27-46)

This drawing was executed during the middle of Muin's career which, according to known dated examples, spanned the years between 1635 and 1707. One of his earliest works, dated 1638 , is also included in the exhibition (no. 34).

This example, rendered in an extremely free and lively manner, is one of his best drawings. It depicts a unique subject in which trained animals were used by entertainers, falling into the same genre depicted in numbers 18 and 23 .

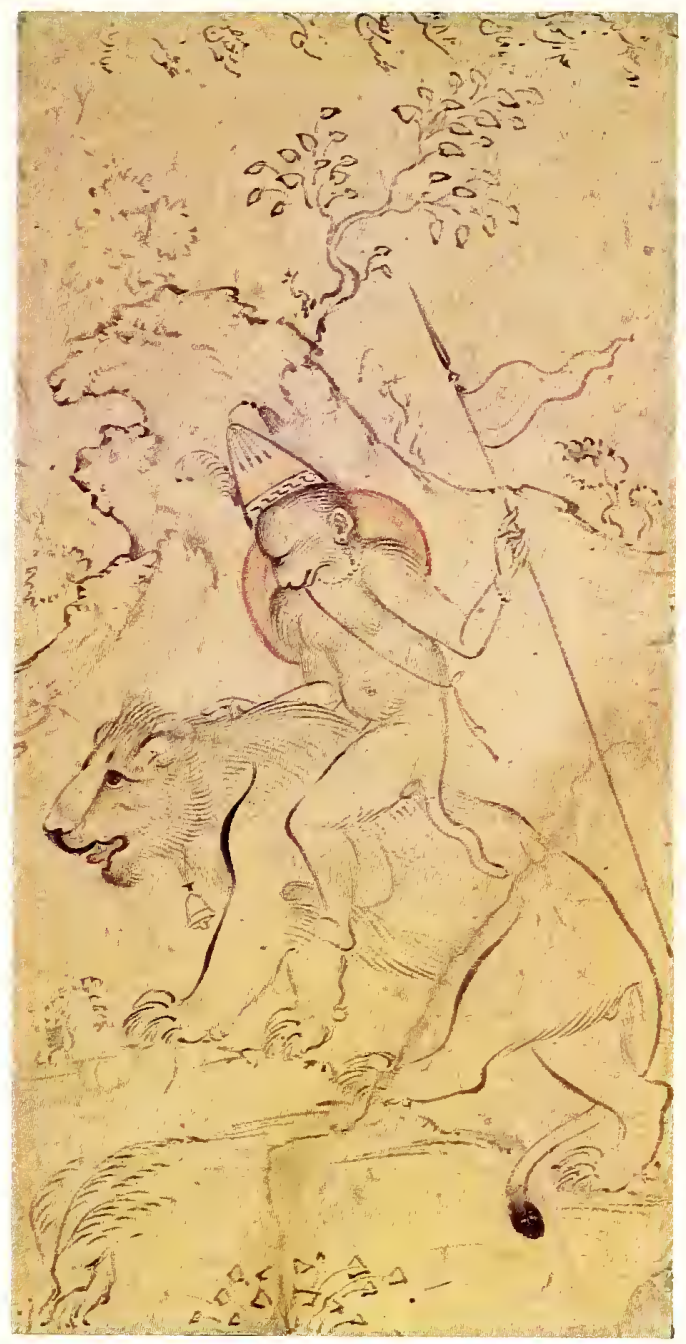


27. Man Scratching His Head From the Riza-i Abbasi Album Signed by Riza

Iran, Safavid period, dated 1598

Black line on paper

$11.7 \times 7 \mathrm{~cm} .(45 / 8 \times 23 / 4 \mathrm{in})$

53.12

One of Riza's earliest drawings represents a man who has removed his large turban and is scratching his head in a preoccupied manner. The figure, portrayed with earthy naturalism and humor, is attired in a long garment held at the waist by a wide sash.

The long inscription states that it was made: "in Meshhed, at end of Friday, 10th of Muharrem, 1007 (August 14, 1598) for Mirza Khojegi, in his house, by Riza." Single-page drawings commissioned by wealthy citizens often have similar lengthy comments inscribed by the artists, giving the precise date and place of execution.

This example was made under the most auspicious circumstances: in the city of Meshhed, venerated for its holy shrines; during Muharrem, the most sacred month of the year; and on Friday, the day of rest and worship for the Muslims The patron, Mirza Khojegi, was probably a highly devout person, and the figure most likely represents one of the Meshhed pilgrims
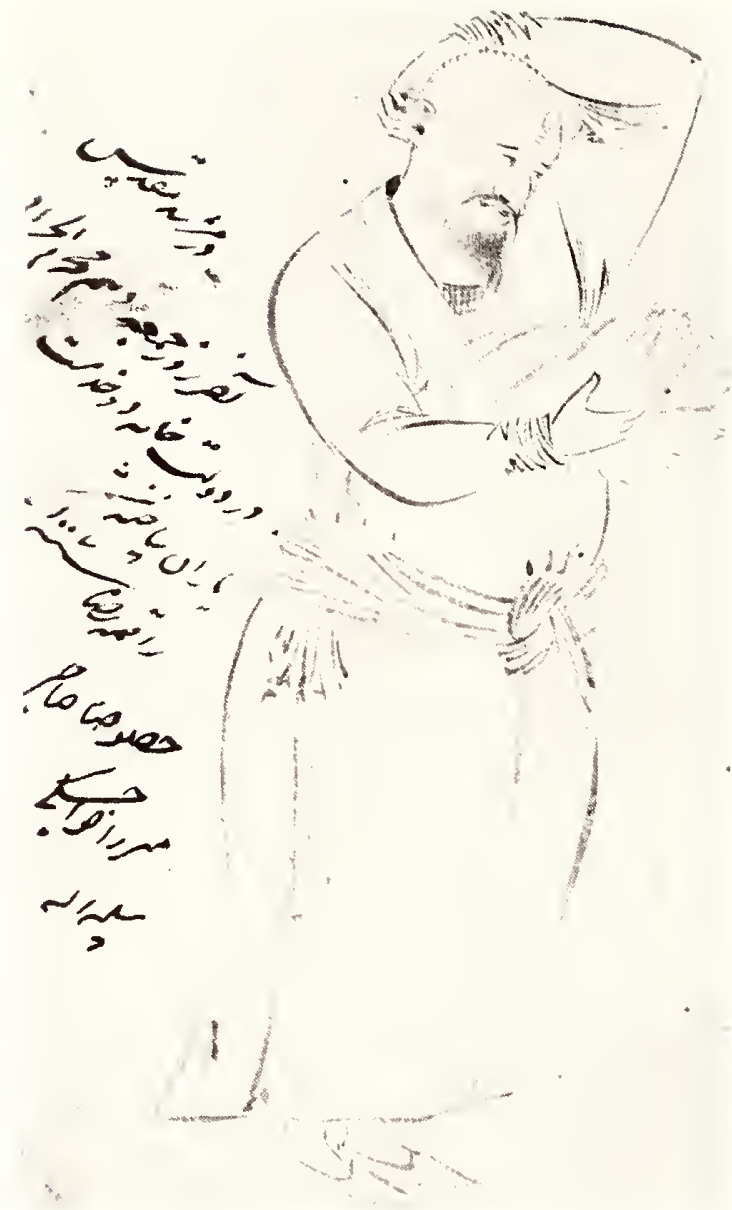
28. Puzzle Drawing of Horses From the Riza-i Abbasi Album Signed by Riza-i Abbasi Iran, Safavid period, dated 1616

Black line on paper

$12 \times 15.4 \mathrm{~cm} .(43 / 4 \times 61 / 16 \mathrm{in}$. 53.23

Puzzle sketches of two horses joined so as to represent two pairs were popular during the 17th century. The inscription at the bottom of the sheet is written in a style which differs from the handwriting found on Riza's other drawings. It reads: "9th of Shavval, 1025 (October 20, 1616), by Riza-i Abbasi."

Two later inscriptions added to the right margin can be partially deciphered and contain the name of a former owner, Mirza Abu'lKasim, and the date 1297 Hijra, or 1879 A.D. This information is quite significant, since it indicates that the ablum could not have been compiled before that date.

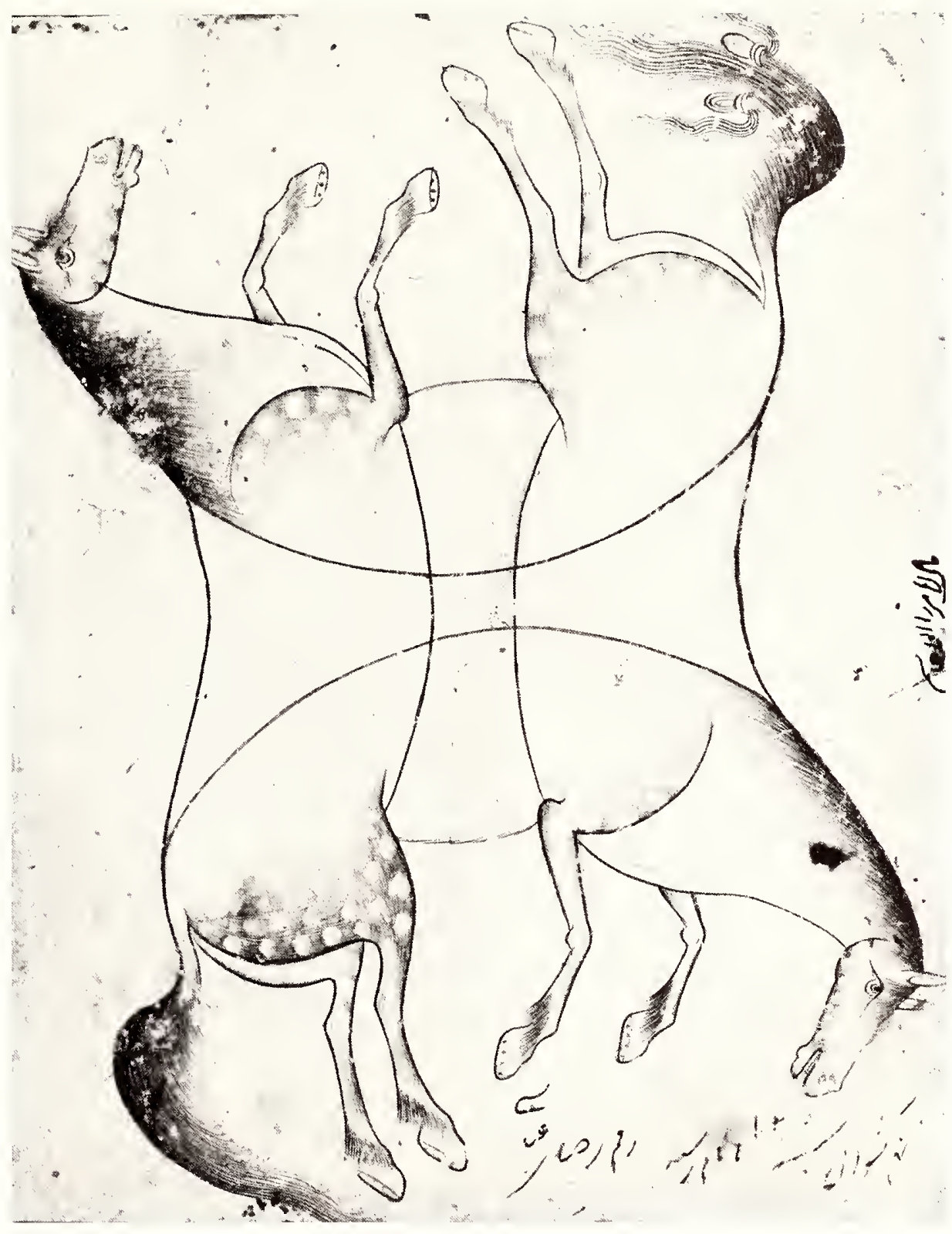




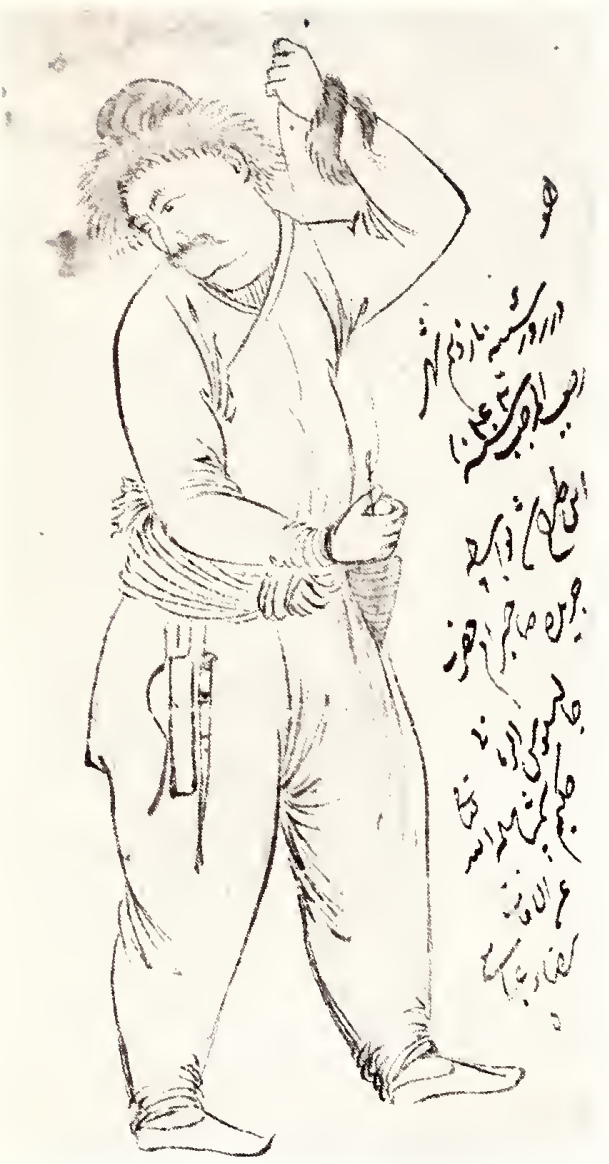

29. Man with a Spindle

From the Riza-i Abbasi Album Signed by Riza-i Abbasi

Iran, Safavid period, dated 1633

Black line on paper; tinted with red, mauve and green

$11.6 \times 6.2 \mathrm{~cm} .\left(4^{9} / 16 \times 2 \% / 16 \mathrm{in}\right.$. $)$ 53.25

The tinted drawing represents a man wearing a fur-brimmed hat and baggy pants, spinning thread from a piece of wool wrapped around his arm. His hat and pants are tinted green, the wool and spool of thread are painted red, and the fur brim on his headdress is rendered in mauve.

The inscription on the right half of the sheet states that the drawing was made: "on Saturday, 11th of Rajab, 1042 (January 22,

1633), for a renowned physician named Shamsa, "the Galen of his time, by Riza-i Abbasi."
The outlines of the figure are perforated, suggesting that it was used as a stencil. It is highly unlikely that a finished drawing, specifically commissioned by a physician, would have been used as a stencil. It is possible that the perforations were done at a later date, after the drawing had changed hands.

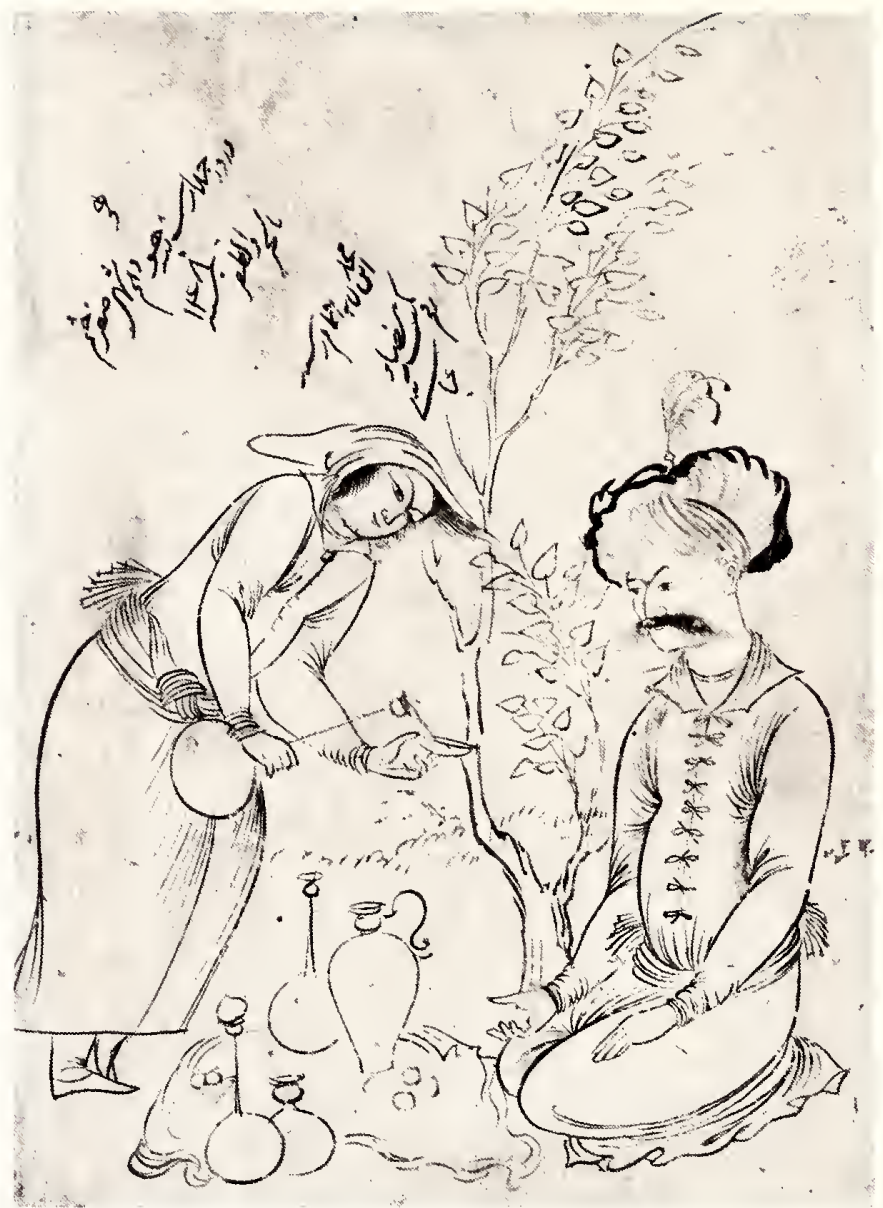

30. Shah Abbas and a Cupbearer From the Riza-i Abbasi Album Signed by Riza-i Abbasi Iran, Safavid period, dated 1638

Black line on paper; tinted with red

$12.4 \times 9 \mathrm{~cm} .(47 / 8 \times 39 / 16 \mathrm{in}$. 53.27

A distinguished figure with a long drooping mustache sits in a kneeling position next to a tree; in front of him is a piece of fabric with fruit, tall-necked bottles and jars. A youthful attendant pours wine from a bottle into a small cup, ready to offer it to the seated personage. The scene is executed in black line with red applied only to the turban of the main figure. The inscription states that the drawing was made on:

"Wednesday, 10th of Safar, 1048 (June 23, 1638), by Riza-i Abbasi."
The figure with a feather attached to his turban resembles Shah Abbas. However, the death of the shah predates the inscription on the drawing by nine years. Either the inscription was added at a later period, or this sketch was made after the death of Shah Abbas, to honor his memory. 
31. Youth Filling Wine Bottles From the Riza-i Abbasi Album Signed by Riza-i Abbasi

Iran, Safavid period, dated 1639

Black line on paper

$13.5 \times 10.6 \mathrm{~cm} .(5 \% / 16 \times 43 / 16 \mathrm{in}$. 53.28

The drawing depicting a youth filling a bottle from a large wine jar contains two inscriptions. On the upper right is a statement which reads: "drawing by the humble Riza-i Abbasi"; the other, on the bottom, states that it was: "made on the night leading to the 8th of Ramazan, 1048 (January 12-13, 1639)."

The scene was rapidly sketched and depicts a variety of jars and bottles together with a bowl of fruit placed at the foot of a tree; rocks and vegetation cover the ground while decorative clouds appear in the sky. The saki, or cupbearer, rests the single-handled large jar on his knee, pouring its contents into a funnel placed on the lip of one of the bottles. The figure wears a large turban with crisp folds and two curly locks fall on either side of his face. He is characteristic of the type of youth frequently represented in Riza's drawings.

The jar has a scalloped ring around the neck and is decorated with a branch and two birds, similar to the one seen in number 24.

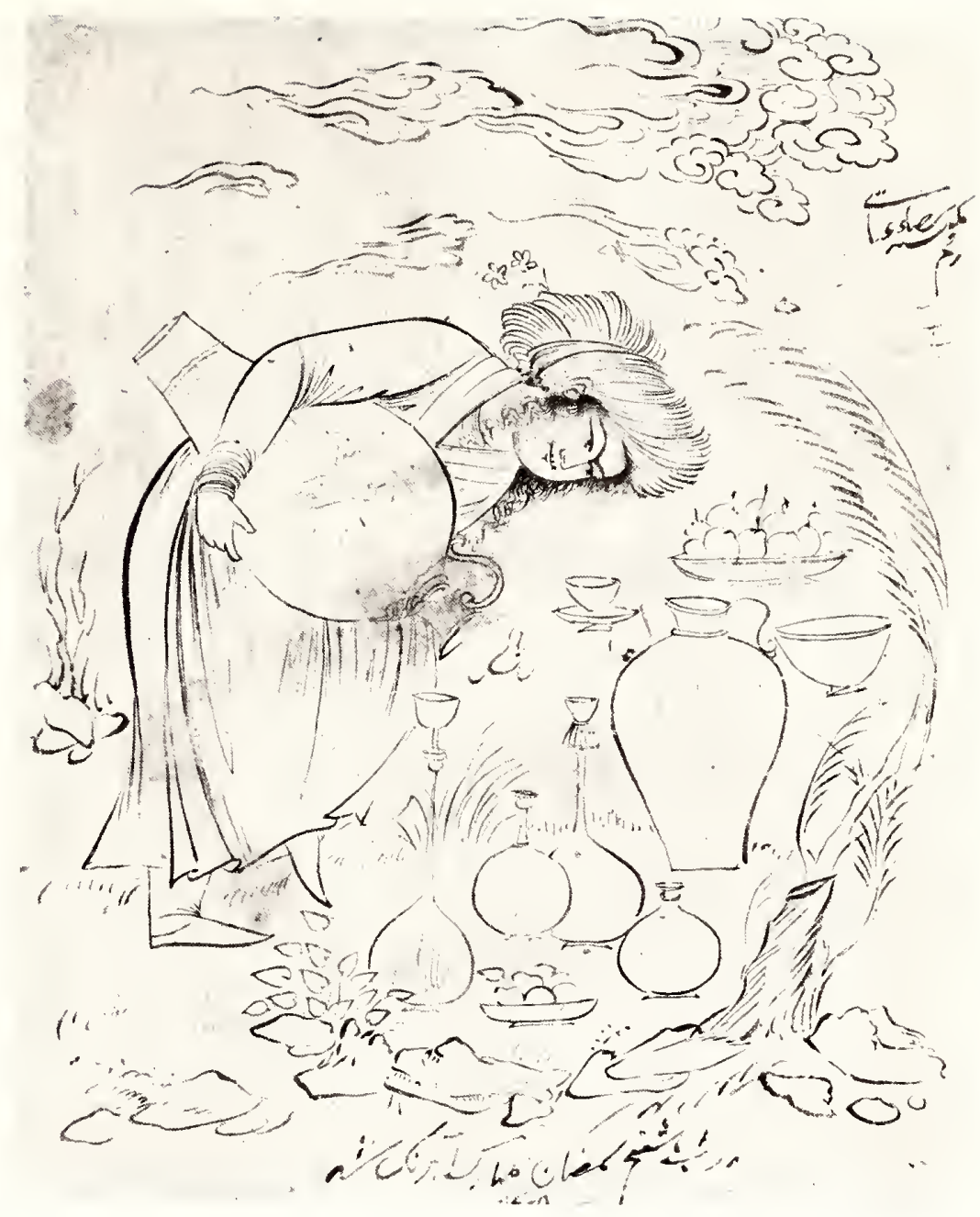


32. Man with a Large Turban From the Riza-i Abbasi Album Signed by Riza-i Abbasi

Iran, Safavid period, mid- $17 \mathrm{th}$ century

Black and red lines on paper $16 \times 8.7 \mathrm{~cm} .(65 / 16 \times 37 / 1 \mathrm{in}$. 53.29

A beardless figure with a large turban sits in a kneeling position. surrounded by sketchy landscape elements-including rocks, clusters of flowering shrubs and scalloped clouds. He has a wine cup in one hand and holds a fruit in the other.

Black line is used on the figure and the inscription, while the setting is rendered in brownish red The inscription, almost hidden amidst the shrubs and rocks on the right, states that the drawing was made by: "the humble Riza-i Abbasi."

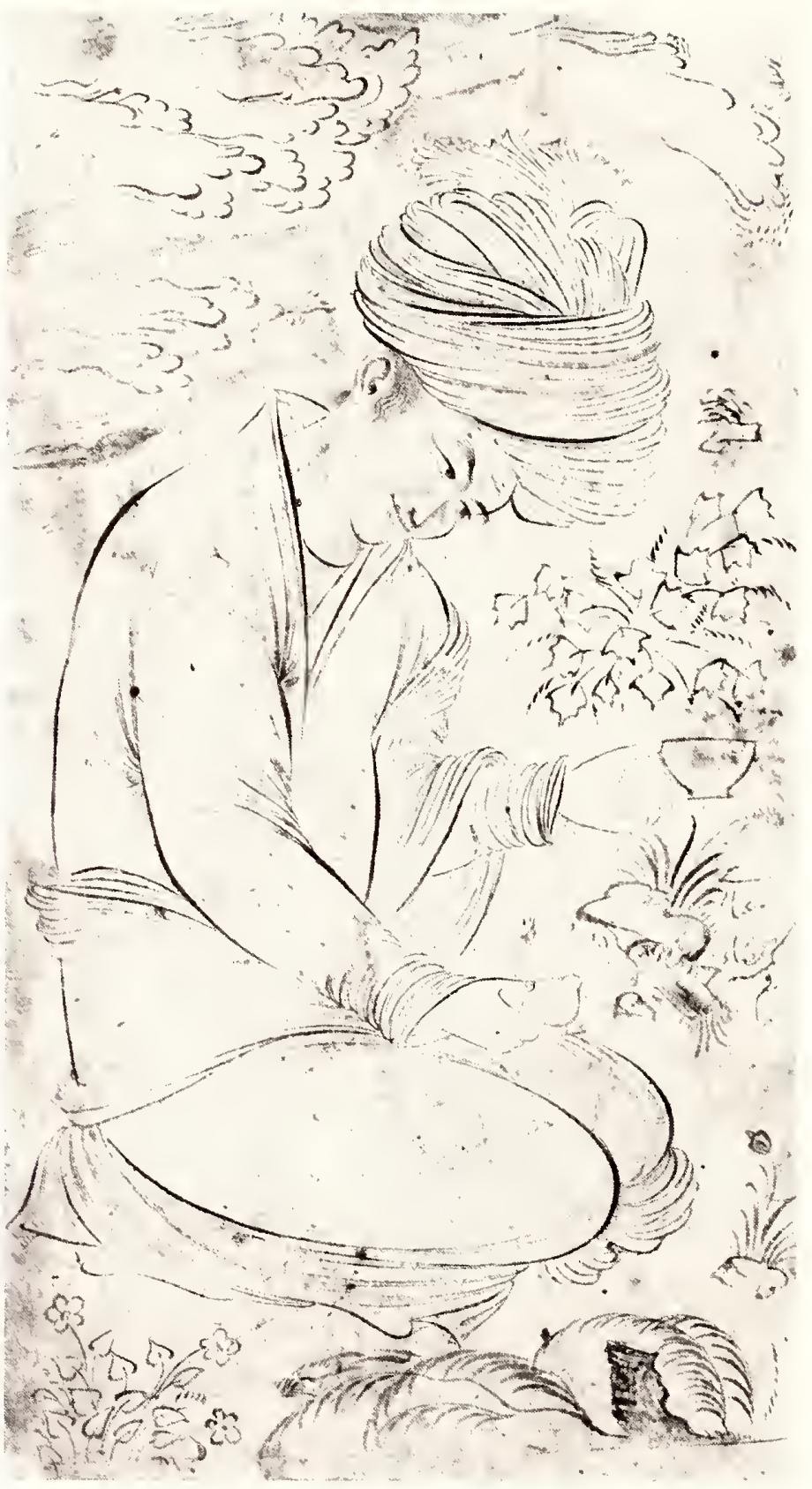


33. Camp Scene

From the Riza-i Abbasi Album Signed by Aka Riza

Iran, Safavid period, dated 1639

Black line on paper

$12.8 \times 7.8 \mathrm{~cm}(51 / 16 \times 31 / 16 \mathrm{in}$. 53.34

This detailed depiction of a nomadic camp shows a tent with a woman spinning wool in the foreground; a donkey with a camel and a man with a child are partially visible behind the tent. An older figure wearing a fur-lined coat and hat converses with a rider in the background while another man carries a large bowl next to the tree on the upper left

The inscription across the top of the folio states that the drawing was made by Aka Riza for the treasury of his "Highness," which must refer to Shah Safi I who ruled between 1629 and 1642 . The second inscription, on the upper left, gives the date:

"Wednesday, 5th of Shavval, 1048 (February 9, 1639)."

This scene is the only one in the album with an inscription specifically stating that it was made for the court.

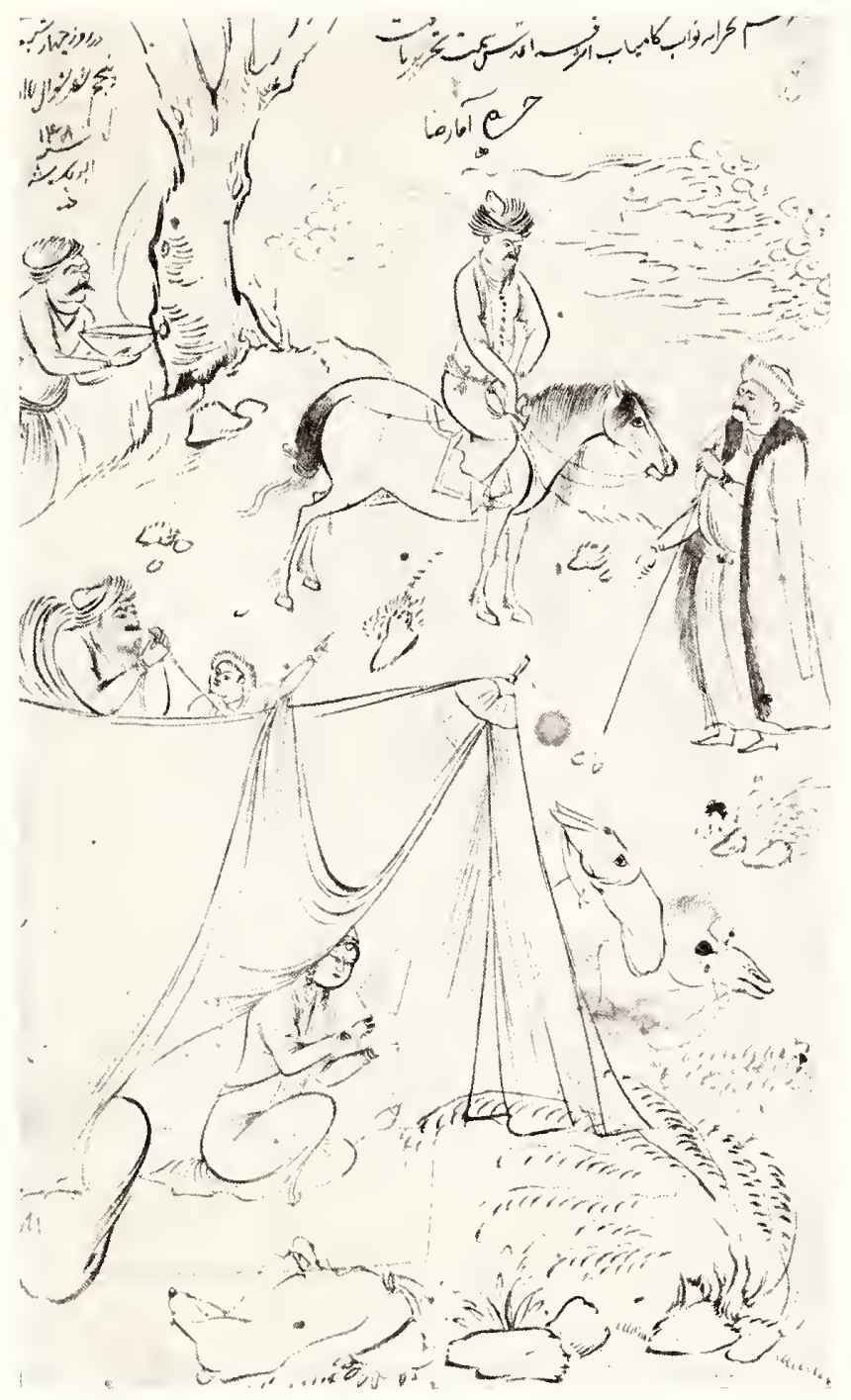




\section{Portrait of a Youth}

Fron the Riza-i Abbasi Album Signed by Muina

Iran, Safavid period, dated 1638

Black line on paper; tinted with red

$11.6 \times 8.4 \mathrm{~cm} .\left(4^{4 / 16} \times 35 / 16 \mathrm{in}\right)$ 53.57

This portrait, execured on Friday, the 20th of Ramazan, 1047 (February 5,1638 ), in the house of a noblem.n whose name could not be deciphered, is the only one in the album by Muin Musavvir, who has signed the drawing as "Muina." It is one of the earliest works of the artist whose name appears on two other drawings from the same collection (nos. 37 and 44).

Muin was the most talented of Riza's students. He executed a number of manuscript illustrations as well as single-page drawings and paintings during his long career which spanned the period from the 1630 s to the first decade of the 18th century

The portrait is drawn in black line with red tints applied to the subject's lips, cap and striped undershirt; a red line also accentuates the contour of his torso

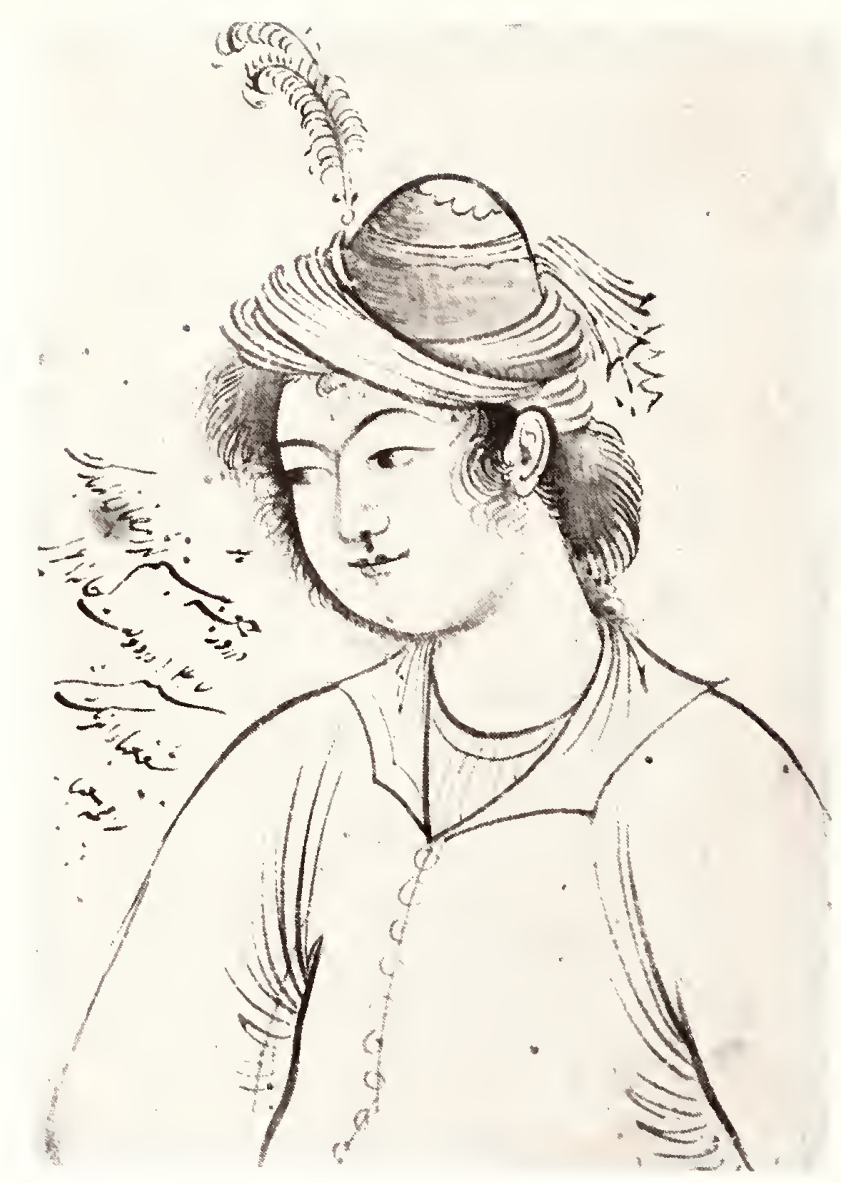




\section{Singing Bird}

From the Riza-i Abbasi Album Iran, Safavid period, dated 1619

Black line on paper

$8.7 \times 14.7 \mathrm{~cm} .\left(37 / 16 \times 5^{13 / 16}\right.$ in. $)$ 53.24

The inscription covering the left half of the drawing states that it was made on: "Friday, 2nd of Zu'l-Kada, 1028 (October 1, 1619), in the house of 'the Galen of his time,' the physician Saifa, by his order. . . " The remaining words could not be read.

The wording is similar to that found on the drawing of a man spinning thread, also made for a physician called "the Galen of his time" (no. 29). Obviously, medical practitioners of the period were wealthy enough to afford the works of popular artists

This example depicts a small bird perched on rocks from which sprays of weeds grow. The bird's open beak suggests the artist intended to illustrate a bird in the midst of song. Similar long-tailed birds with parted beaks appear on several other drawings from the same album (nos. 45, 56, 57 and 58).

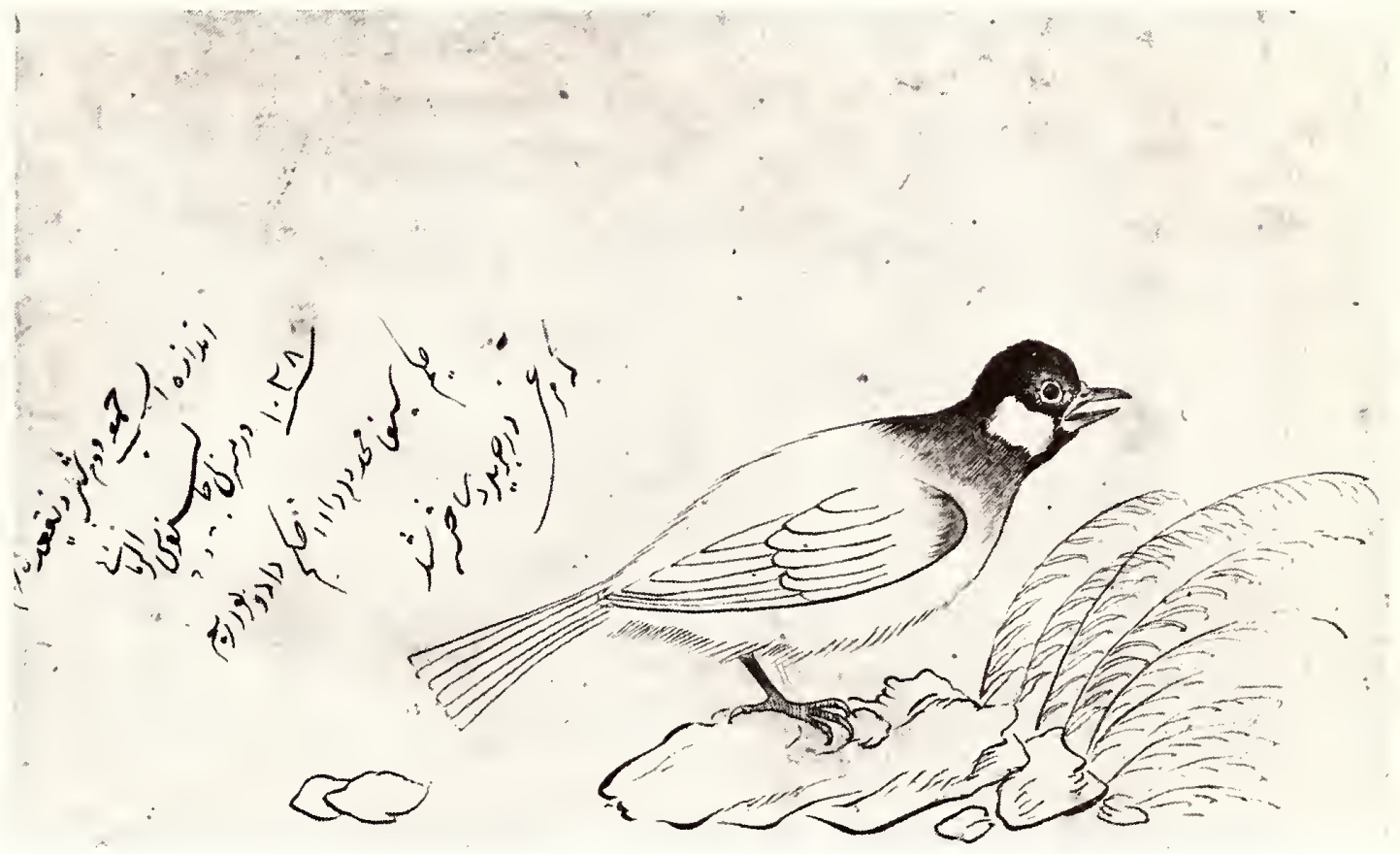


36. Youth with a Wine Bottle From the Riza-i Abbasi Album Iran, Safavid period, dated 1638

Black line on paper

$16.3 \times 9.4 \mathrm{~cm} .\left(6^{7} / 16 \times 3^{11} / 1 \mathrm{t}\right.$ in. $)$ 53.26

A youth holding a tall-necked wine bottle extends a small cup while kneeling on the ground; a spray of branches decorates the background. The youth wears a soft feathery hat and has a flower tucked into his wide sash. The exaggerated drapery on the edges of his cuffs and hem, the articulated folds of his sash and the cloth benearh his knees are characteristic of the brushwork of the Isfahan school.

The inscription on the left has been partially deciphered and states that this drawing was made on Friday, the ninth of Muharrem, 1048 (May, 1638), in the orchard of a personage whose name could not be read. The date is confusing, since Friday was the seventh day of Muharram. Either the inscription was added at a later time, or the artist confused the date, which is a common human error.

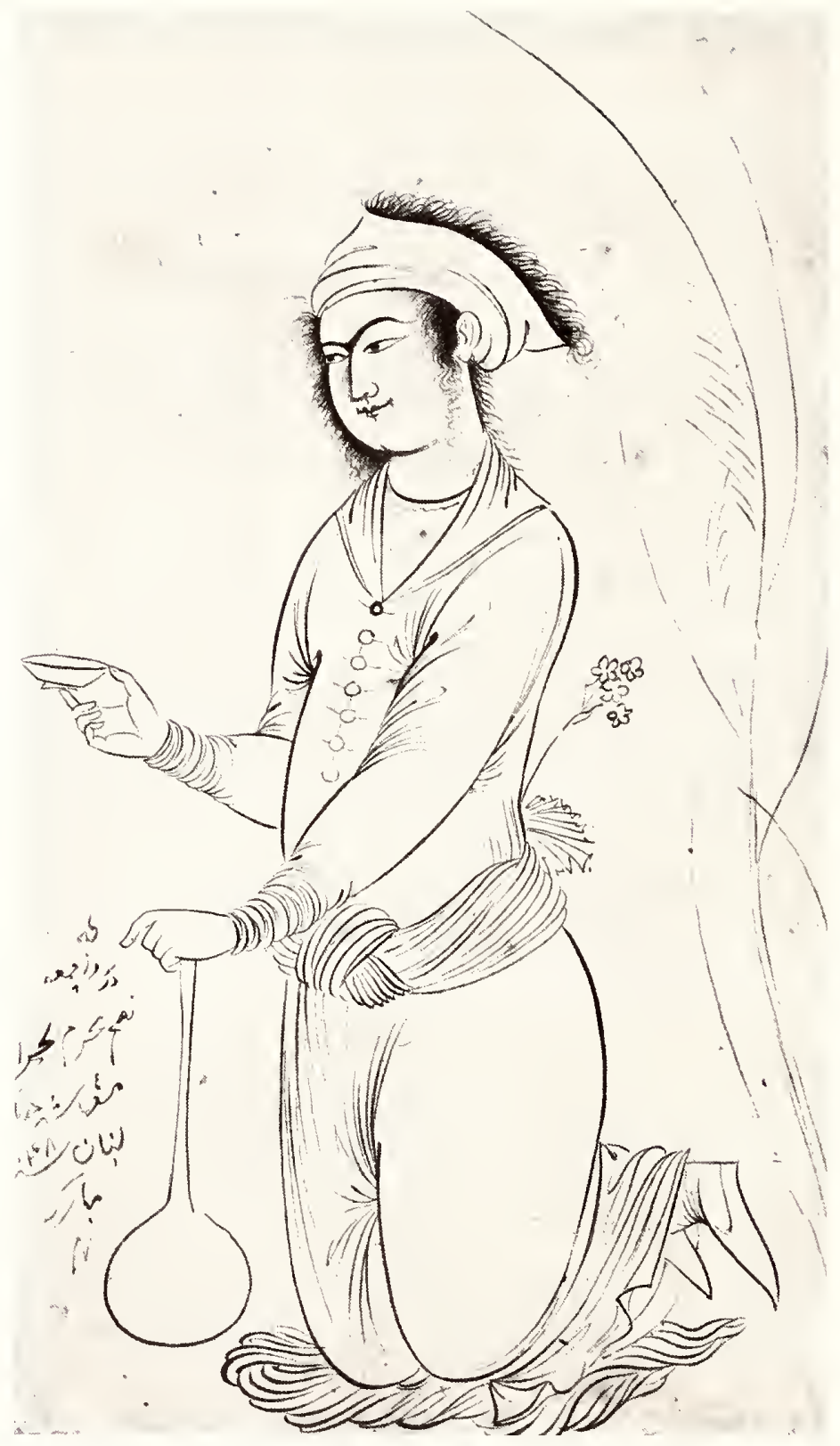


37. Seated Man (top)

Reclining Man (bottom)

From the Riza-i Abbasi Album

Iran, Safavid period, dated 1639

Black line on paper

Top: $11.8 \times 6.9 \mathrm{~cm}$

$(45 / 8 \times 23 / 4$ in.)

Bottom: $6.2 \times 11.9 \mathrm{~cm}$

$\left(27 / 16 \times 4^{11 / 16}\right.$ in $)$

53.30

The two drawings, executed on varying tones of paper by two different hands, are mounted on the same folio. The example on the top depicts a bearded man in a landscape with sheets of paper, a pair of bowls and his spectacles lying on the ground. It is pasted sideways on the page.

The drawing on the lower half of the folio is far more refined and represents a bareheaded, barefooted man reclining against a tree stump. His hair and beard are untrimmed and his clothes are slightly unkempt. He holds a cane in his hand and is gazing wearily into blank space. The in scription above the figure states that the drawing was made on: "Friday, 15th of Safar, 1049 (June 17, 1639), in the domain of my brother's shelter, Aka Muina." The wording of the inscription suggests that the drawing was made in the house of Muin Musavvir

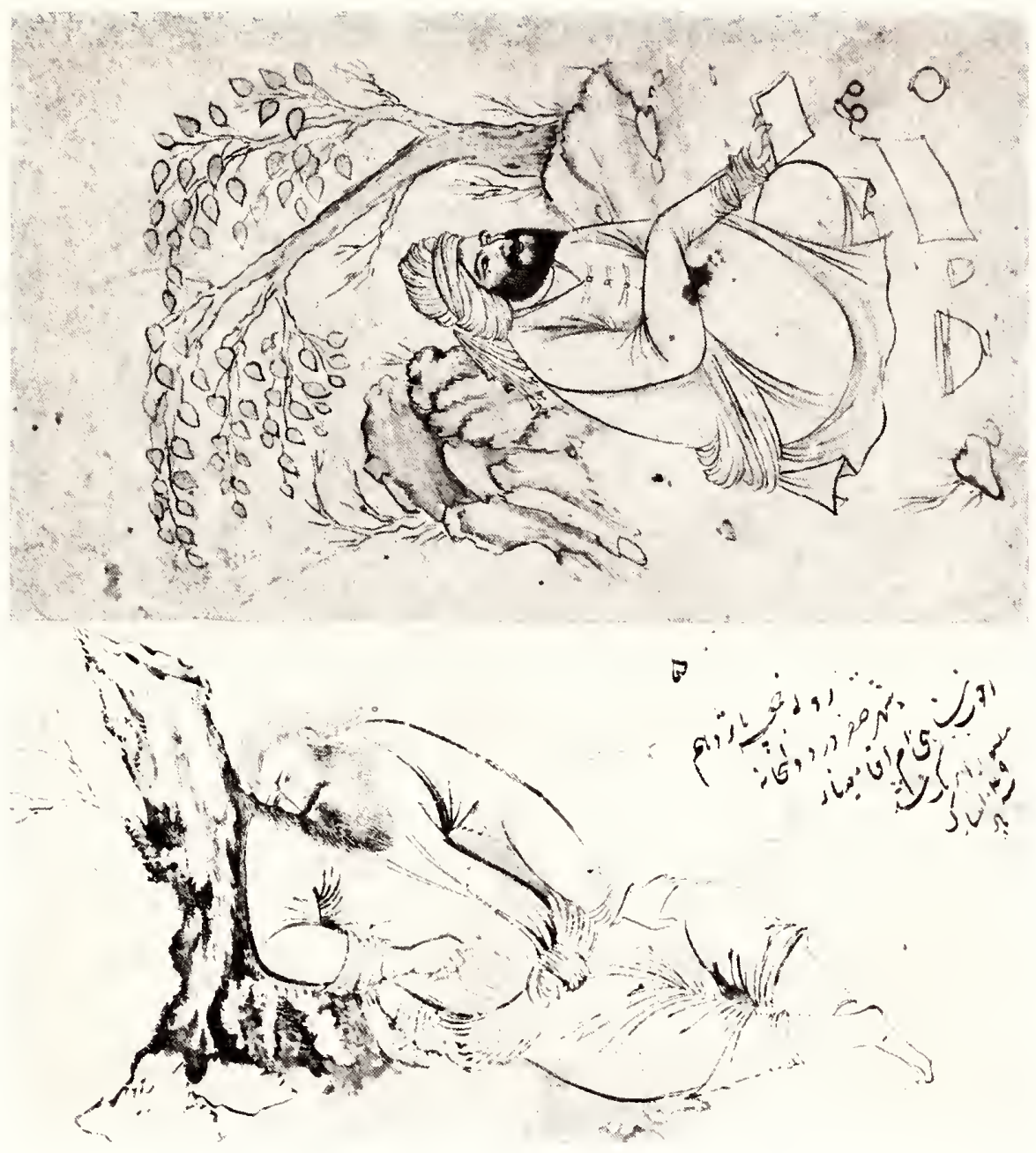


38. Sketch for Layla va Majnun From the Riza-i Abbasi Album Iran, Safavid period, dated 1639

Black line on paper

$13.1 \times 7.7 \mathrm{~cm} .\left(5 \frac{3}{16} \times 31 / 16 \mathrm{in}.\right)$ 53.33

The album contains several shetches made for manuscript illustrations, among which is this example depicting an episode from Nizami's love story of Layla and Majnun. The scene shows the emaciated Majnun conversing with his uncle while surrounded by the wild and tame animals which befriended him in the wilderness. The incomplete drawing of two rabbits on the lower left suggests that the work was not finished. There are several purplish stains on the paper.

The inscription on the upper left reads: "on Thursday, on the 6th of Shavval, in the year 1048 (February 10,1639$)$, this was made."

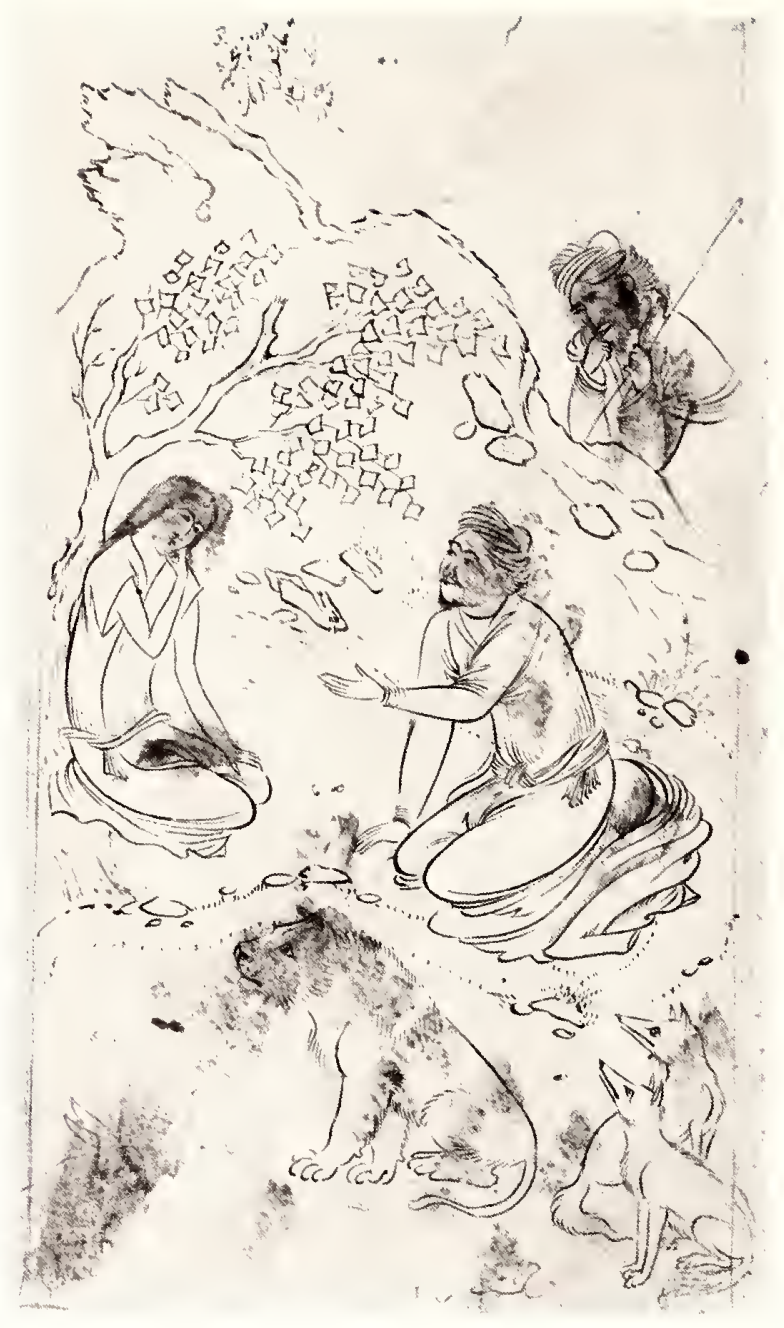


39. Mughal Official (left) Seated Man (right)

From the Riza-i Abbasi Album

Iran, Safavid period, dated 1641

Black and red lines on paper; tinted with green and white Left: $9.9 \times 6.7 \mathrm{~cm}$ $\left(3^{15 / 16 \times 25 / 8 \text { in. })}\right.$

Right: $9.7 \times 7.1 \mathrm{~cm}$. $\left(3^{13 / 16} \times 2^{13 / 16 \mathrm{in} .)}\right.$

53.14

The drawing on the left represents a Mughal official standing with his arms extended. The figure, drawn in black, wears the traditional garments of the Indian court. The inscription states that the drawing was made on Tuesday, 12th of Shavval, 1050 (January, 1641). Either the day of the week or the date is incorrect, since Tuesday fell on the ninth or 16th of Shavval in 1050 Hijra.

The same inconsistency occurs on two other inscriptions (nos. 36 and 40). This personage possibly represents Khan Alam, who was sent by Jahangir to the court of Slah Abbas in 1618-19.

The other drawing is executed in red with green washes used in the turban and in the lining of the coat and pants; the handkerchief lying across the figure's lap is painted white. The roguishlooking man is shown seated with his wrists crossed, almost as if bound and imprisoned

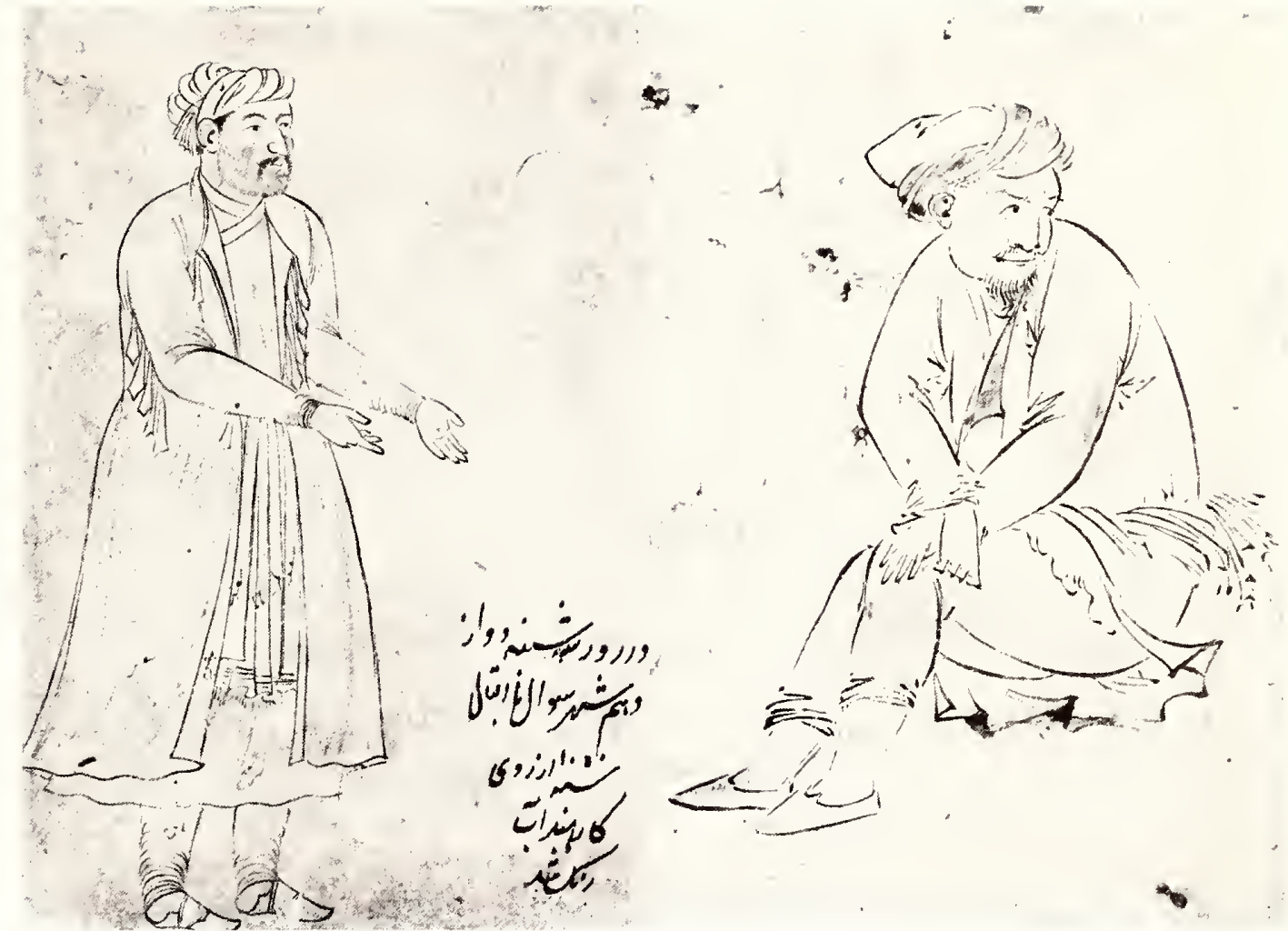


40. Old Man Holding a Staff From the Riza-i Abbasi Album Iran, Safavid period, dated 1641

Black line on paper $10.8 \times 7.3 \mathrm{~cm} .(41 / 4 \times 27 / 8 \mathrm{in})$ 53.39

According to the inscription, this drawing was made on Tuesday, the 12th of Shavval, 1050 (January, 1641), after an Indian work As in the previous inscription, the statement contains an inconsistency between the day of the week and the date of the month, Tuesday being the ninth or 16 th of Shavval.

It is difficult to imagine the "Indian" model that was used for this portrait, since the figure type, the costume and the style of execution are characteristic of the mid17 th-century school of Isfahan
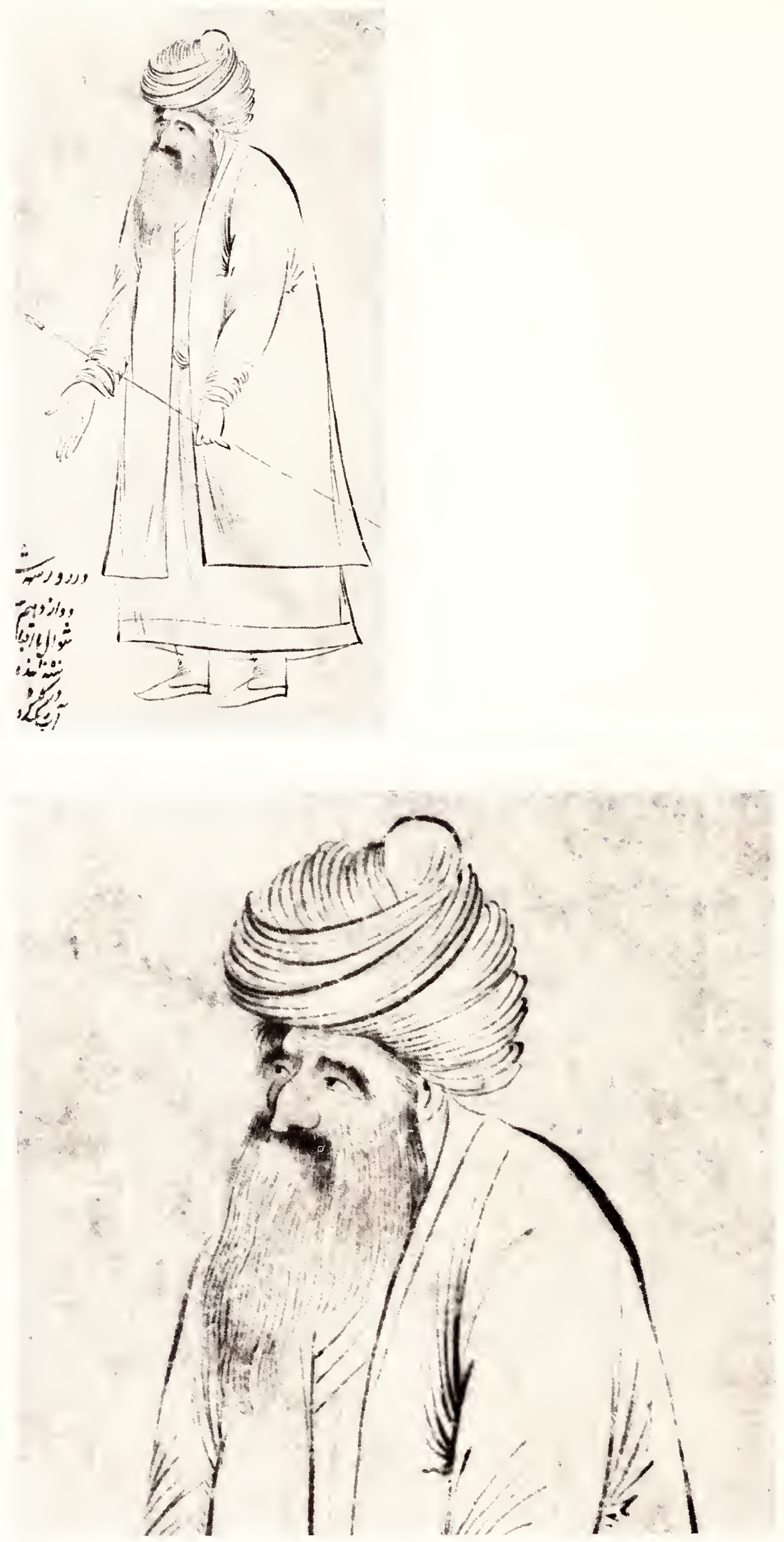


\section{Lovers}

From the Riza-i Abbasi Album Iran, Safavid period, dated 1642

Black line on paper

$13.2 \times 6.8 \mathrm{~cm} .\left(5^{3 / 16} \times 2^{11 / 16 \mathrm{in} .}\right)$ 53.41

One of the finest drawings in the album represents a handsome couple, executed in soft but controlled lines. The man has a long drooping mustache and wears the turban of the age; his consort wears a small cap tied at the back and a thin ring on her nostril. The harmonious relationship of the figures reflect their emotional attachment.

The extremely sketchy inscription above the figures is partially readable and states that the drawing was made "in the night of Thursday, 11th of Muharrem, 1052 (April 9-10, 1642), in a lane (?) . . ."; the identification of the location could not be established.

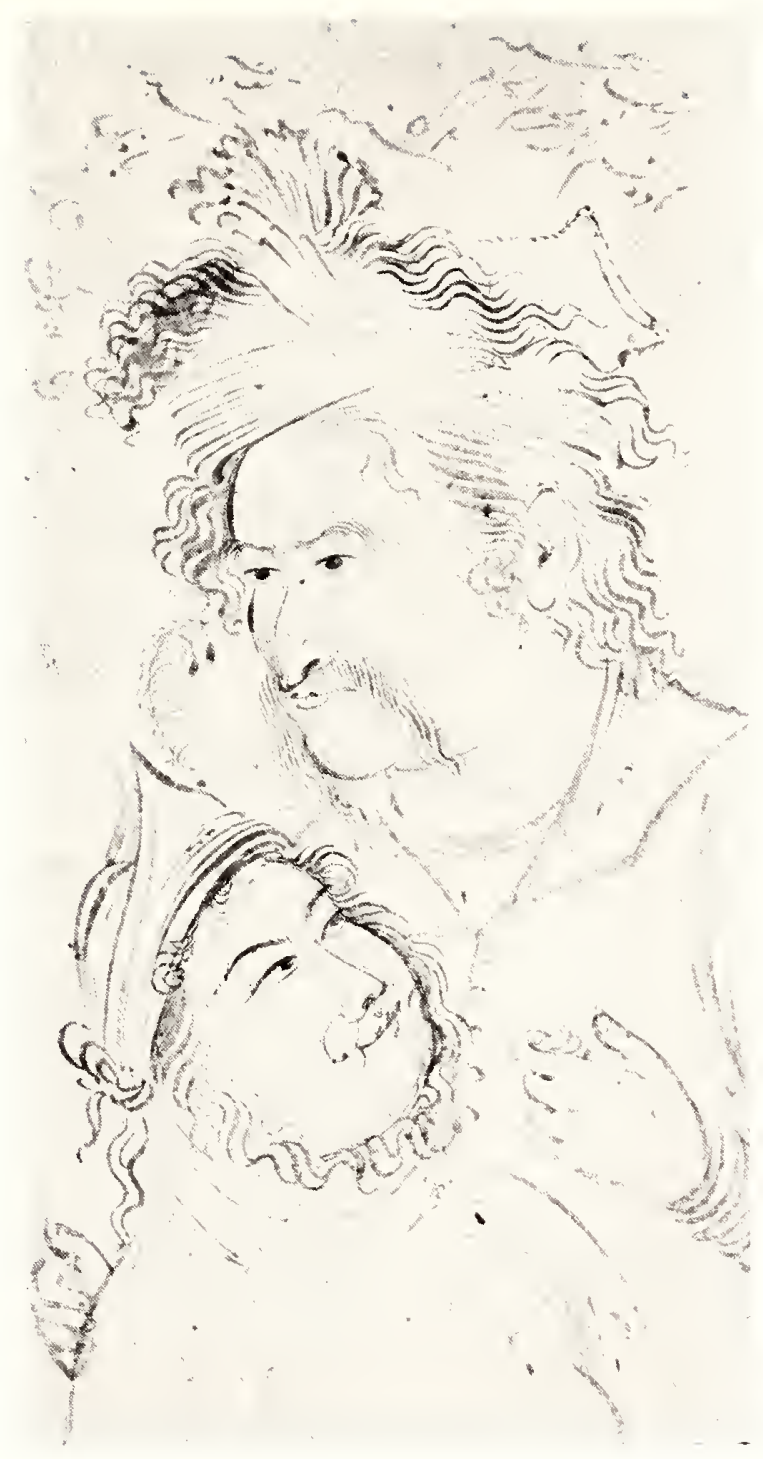


42. Polo Player

From the Riza-i Abbasi Album

Iran, Safavid period, dated 1642

Black and red lines on paper; tinted with purple, blue and green

$15.7 \times 10.3 \mathrm{~cm} .(33 / 16 \times 41 / 16$ in. $)$ 53.44

There are several tinted drawings in the album which indicate that they were finished products. This scene represents a polo player rendered in full color, galloping on a lively horse with craggy rocks, tree stumps and bushes rising on the horizon. A group of rocks with foliated plants appears in the foreground while rippled clouds decorate the sky. A feeling of depth is created by the position of the horse and tider; they are shown from the back, turning in to the picture in a spiral movement.

The young rider wears a furbrimmed cap and a green outfit lined with blue. Black and red lines are used interchangeably: the latter are employed to draw the landscape elements in the background as well as the outlines of the horse.

The inscription above the rocks merely states that the drawing was made in the middle of Shaban, 1052 (November, 1642).

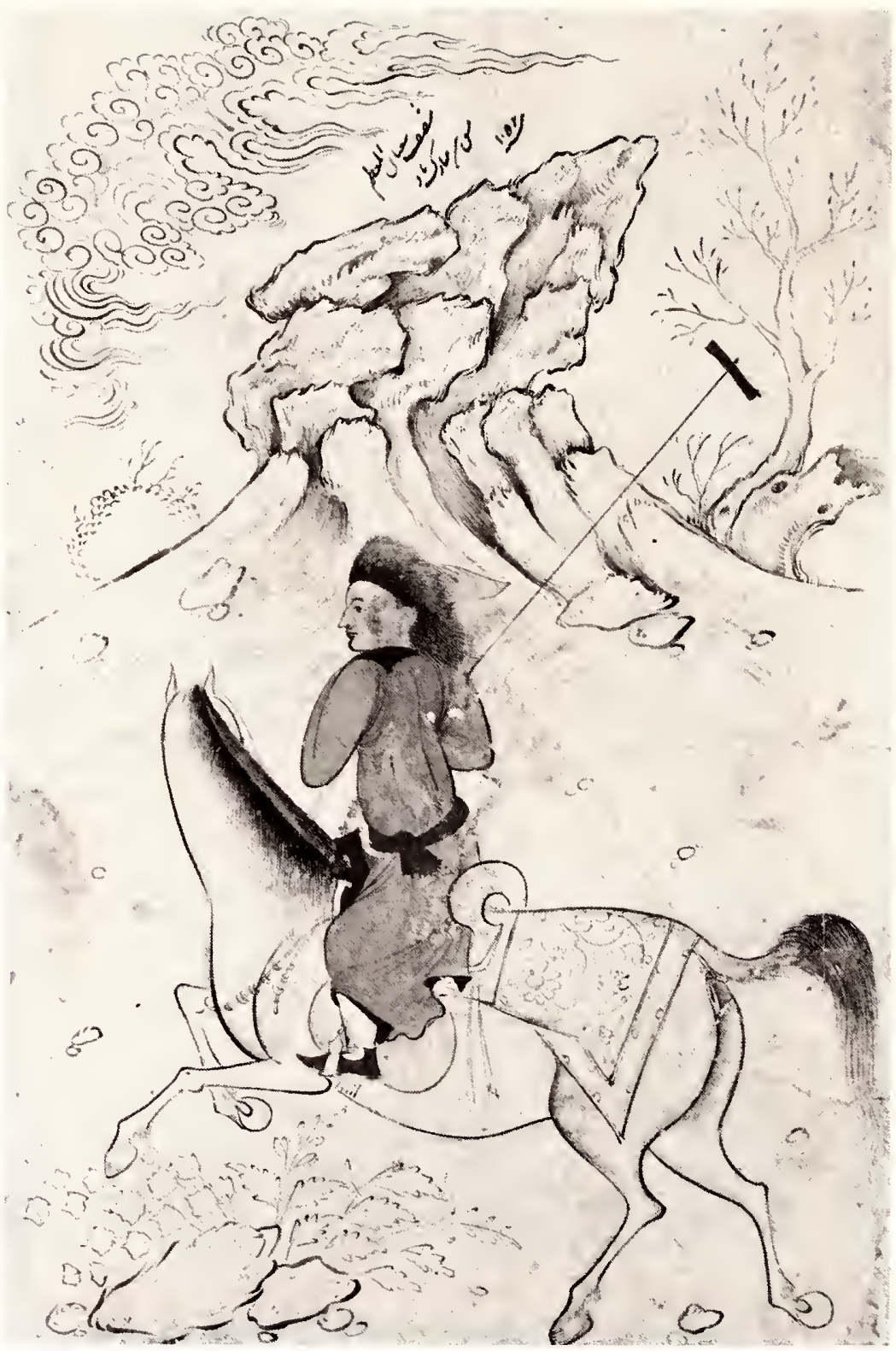




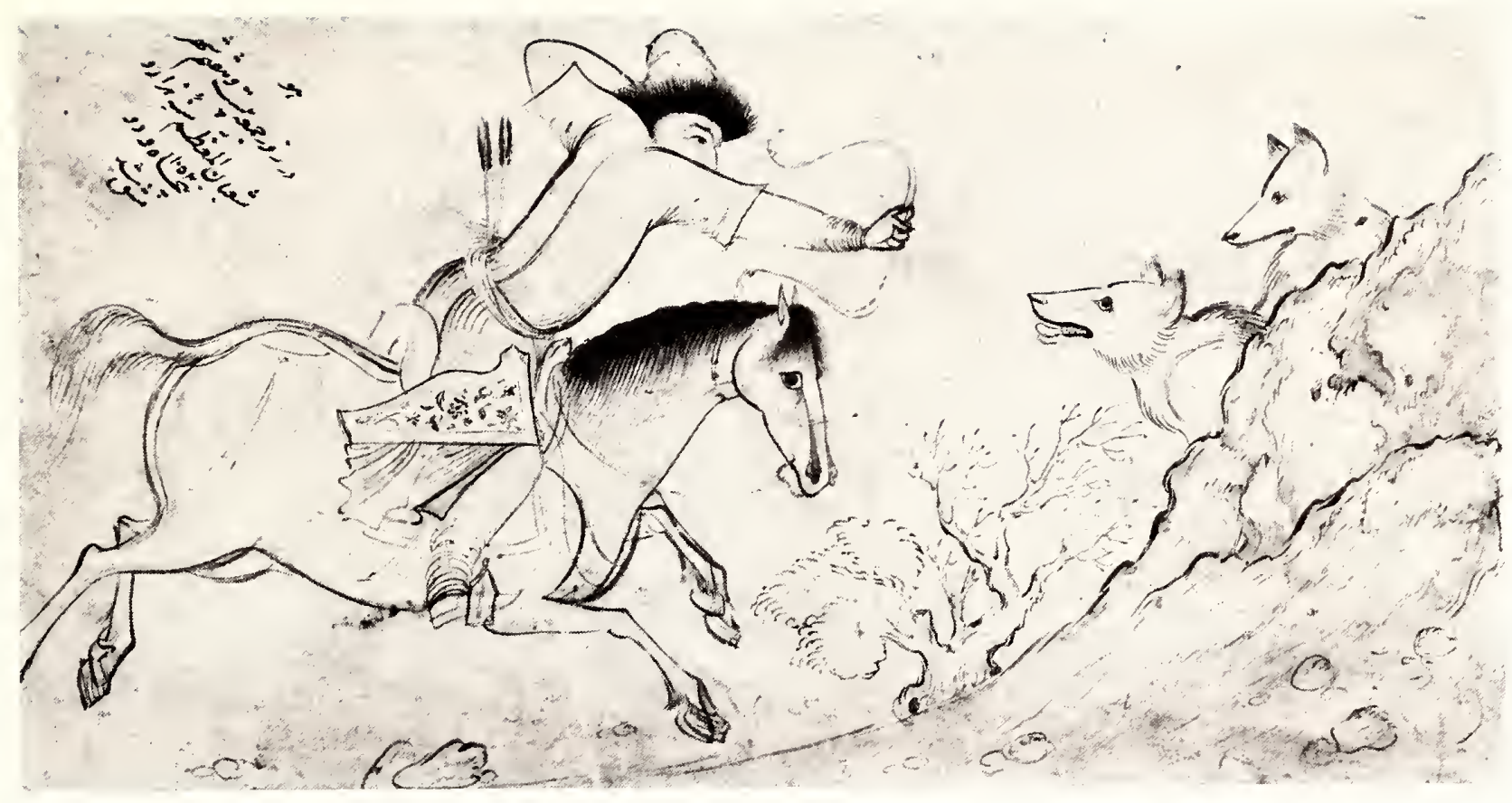

43. Wolf Hunter

From the Riza-i Abbasi Album

Iran, Safavid period, dated 1642

Black and red lines on paper $8.7 \times 16.6 \mathrm{~cm} .(3 \% 16 \times 6 \% 16 \mathrm{in}$. 53.45

Similar to the previous drawing, this scene depicts a galloping rider in a landscape. The figure moves horizontally across the picture frame, shooting at two rather unperturbed wolves parrially hidden behind the rocks. The rider wears a fur-brimmed hat and twists into the picture, his torso shown from the back. An embroidered quiver hangs from his side while two arrows are stuck in his belt .

The drawing is executed in black brush strokes with red lines used exclusively on the horse.

In contrast to the other inscriptions found in the album, this date is written out and given in digits: "on Friday, 27th of Shaban, thousand and fifty-two, 1052 (November 22, 1642)." 
44. Shepherd in the Mountains From the Riza-i Abbusi Album ran, Safavid period, dated 1643

Black hine on paper; tinted with polychrome colors

$6 \times 10.5 \mathrm{~cm},(23 / 8 \times 41 / 8 \mathrm{in}$. 53,48

The minuscule scene depicts a weary shepherd seated on a rock, resting against a rugged mountain; his dog lies at the foot of a tree while several goats and sheep peer over a hill. The artist has drawn the forms with great delicacy and made extensive use of colored washes in the landscape and on the figure. The hues are quite extensive, including various tones of red, blue, green, mauve, brown and gray:

The inscription has been partially deciphered and reads: "on Saturday, 16th of Rabi II, on that day said (?) Muina... and thus this drawing was made in the year 1053." The date given corresponds to July 4,1643 . The casual and narrative manner in which the date is rendered is characteristic of 17 th-century inscriptions.
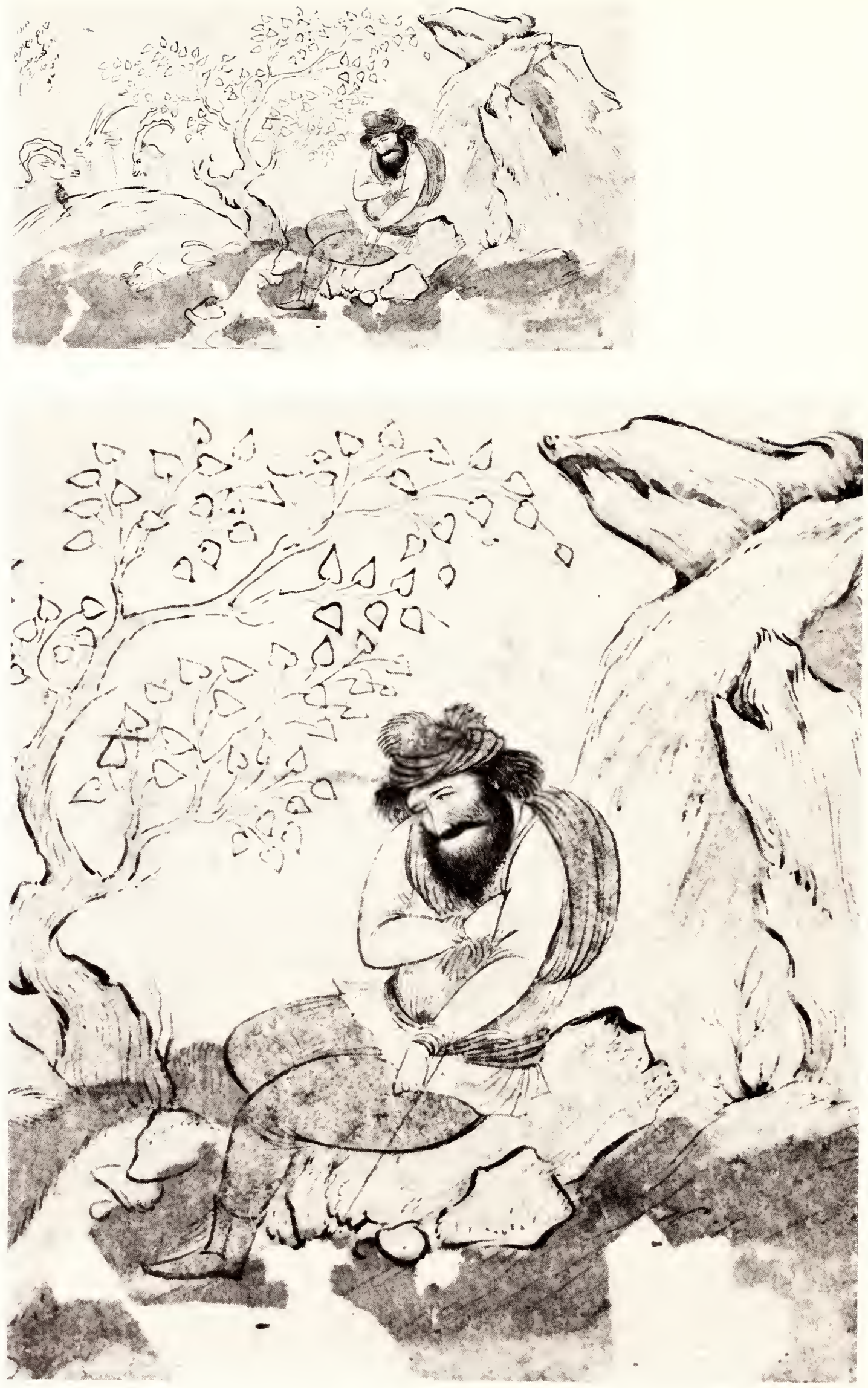
45. Old Man with a Cane From the Riza-i Abbasi Album Iran, Safavid period, mid-17th century

Black line on paper

$13.5 \times 5.6 \mathrm{~cm} .\left(5 \frac{5}{16} \times 23 / 16 \mathrm{in}\right.$.) 53.16

This portrait of an elderly man wearing a voluminous turban and a long coat is an excellent character study. The face is highly expressive with twinkling eyes and a benevolent smile. The figure stands in front of a high hill with rocks, plants and a solitary bird added to the background.

According to the inscription on the lower left, the drawing was made in Herat on the 10th of Safar; the year of execution is omitted.
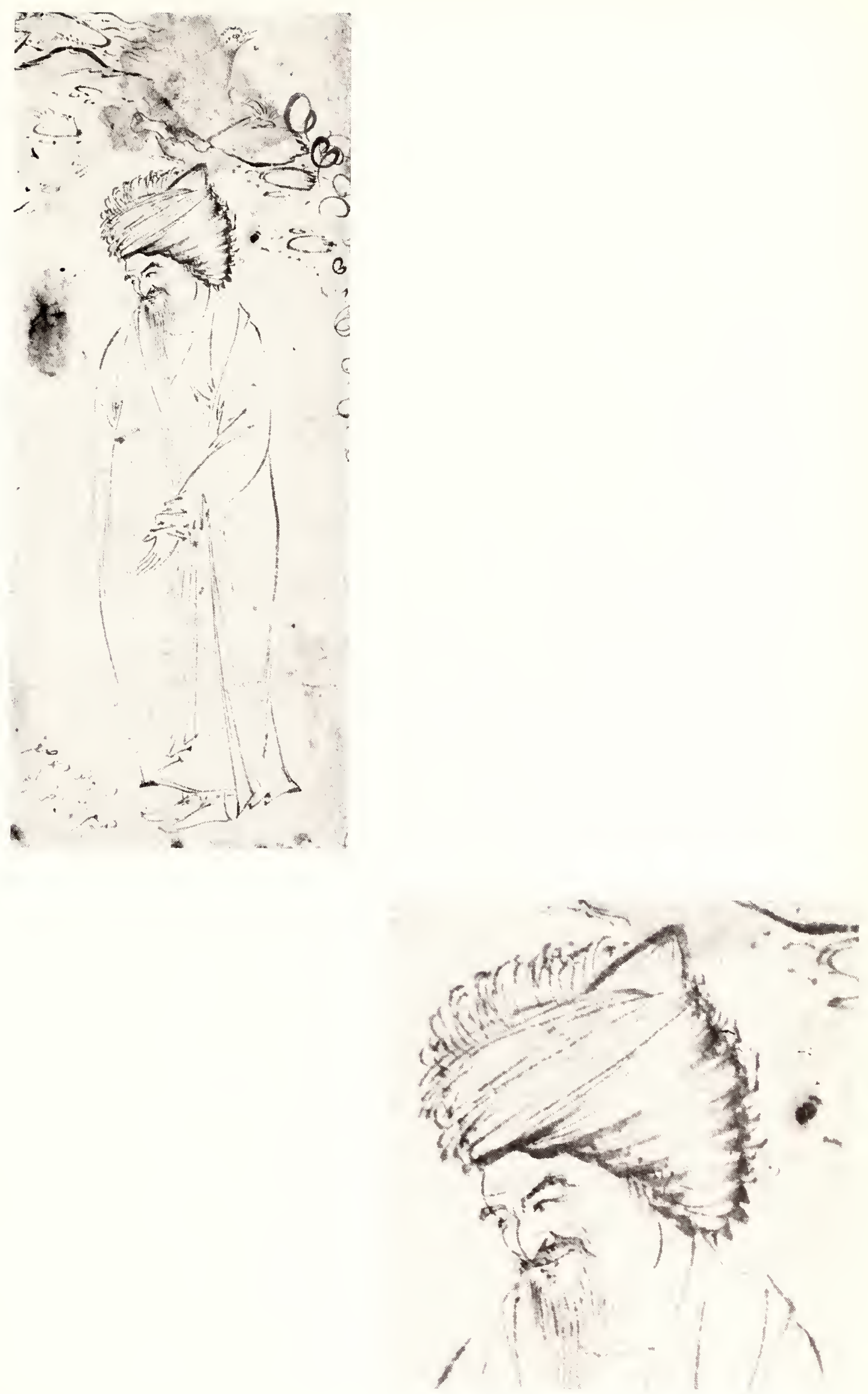


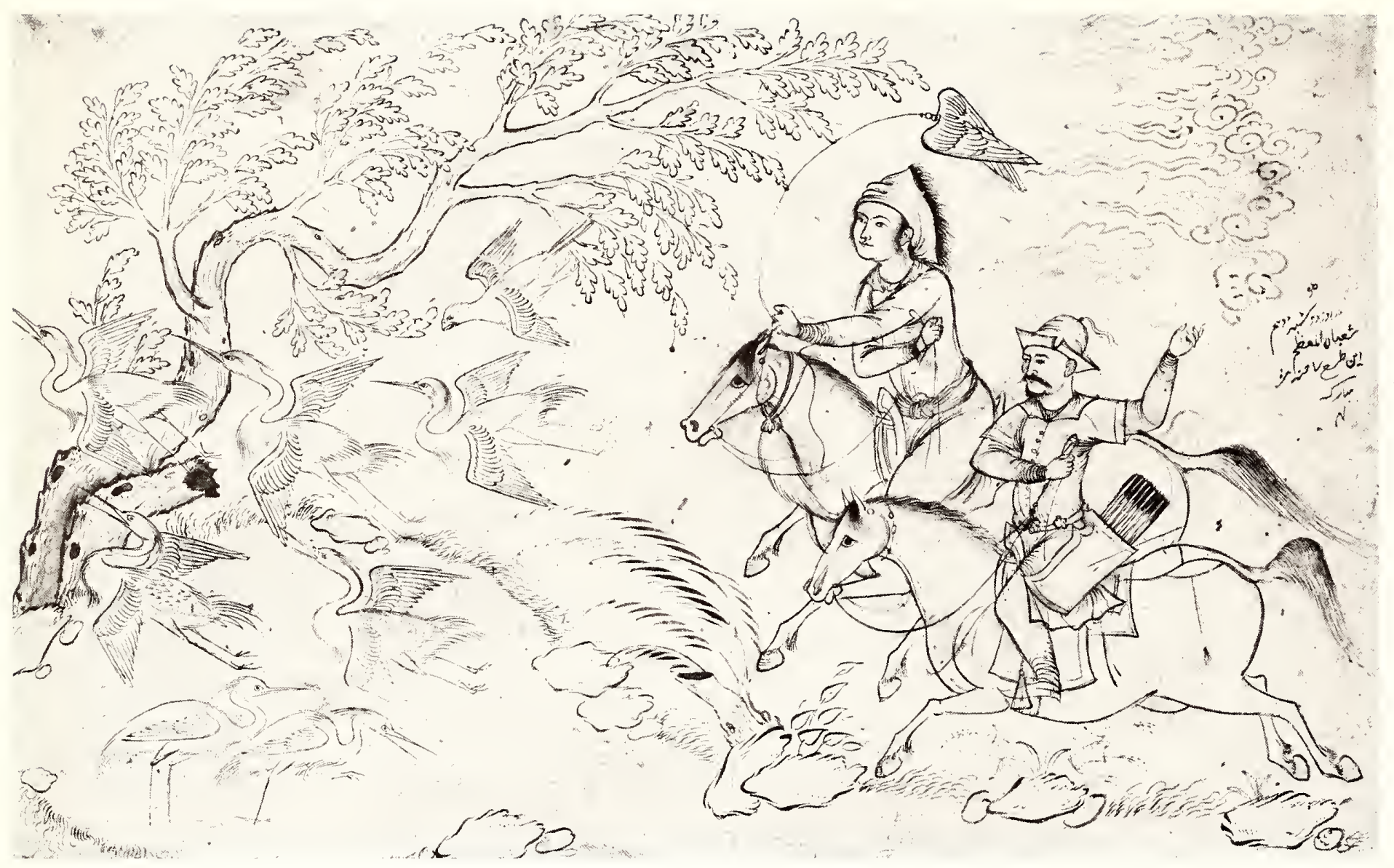

46. Two Hunters with a Falcon From the Riza-i Abbasi Album Iran, Safavid period, mid- 17 th century

Red line on bluish-green paper; tinted with blue and yellow

$13.4 \times 21.7 \mathrm{~cm} .\left(5 \frac{16}{16} \times 8 \% \frac{16}{6}\right.$ in. $)$ 53.46

A dramatic movement is created by the two riders who gallop towards the stream, their horses and fierce falcon arousing a group of cranes. The sweeping movement of men, horses and birds is counteracted by an articulated tree which curves gracefully over the scene, creating a revolving and self-contained composition.

One of the hunters is a middleaged man with a mustache and a short beard; he wears a splitbrimmed hat and carries a quiver filled with arrows. The other is a younger figure who wears a feathered cap and holds the string of a flying decoy. The ferocious hawk swoops down on its prey; five of the cranes have been alerted and hurriedly take flight while two others still paddle in the water.
The scene is full of details accentuating the movement, such as trailing clouds and softly bent branches which follow the direction of the riders. In spite of a multitude of elements, the scene is spaciously and carefully composed.

The use of tinted paper is rather unusual although red lines were used on other examples in the album (nos. 48 and 57).

Similar to the legend on the previous drawing, this inscription gives only the day and omits the year: "Monday, 10th of Shaban." 
47. Man with Spectacles (left) Shafi al-Abbasi (right) From the Riza-i Abbasi Album Iran, Safavid period, mid-17th century

Black line on paper; tinted with red; white lead applied for corrections

Left: $10.8 \times 8.3 \mathrm{~cm}$.

( $41 \frac{1}{4} \times 3 \frac{5}{16}$ in.)

Right: $10.4 \times 6 \mathrm{~cm}$

$(41 / 8 \times 23 / 8$ in. $)$

53.17

The drawing on the left is a remarkable study of a slightly overweight elderly man who wears spectacles and holds a pad under his arm. The sketch was corrected with white lead which has discolored and appears as dark gray. This technical feature is also found on a number of other drawings included in the album. The corrected and original lines of certain parts of the figure are still visible, especially in the hands and legs.

The accompanying drawing represents a seated youth, resting his drawing pad on his knee; working with a fine brush, he is painting a flower. Red is applied to the furbrimmed hat of the young artist as well as to the petals of his flower.

The inscription on the sheet with the old man identifies the young artist as "Shafi al-Abbasi."

Muhammed Shafi Abbasi was Riza's son and excelled in the painting of flowers

It has been suggested that the drawing of the old man is a selfportrait of Riza who also executed the portrait of his son.
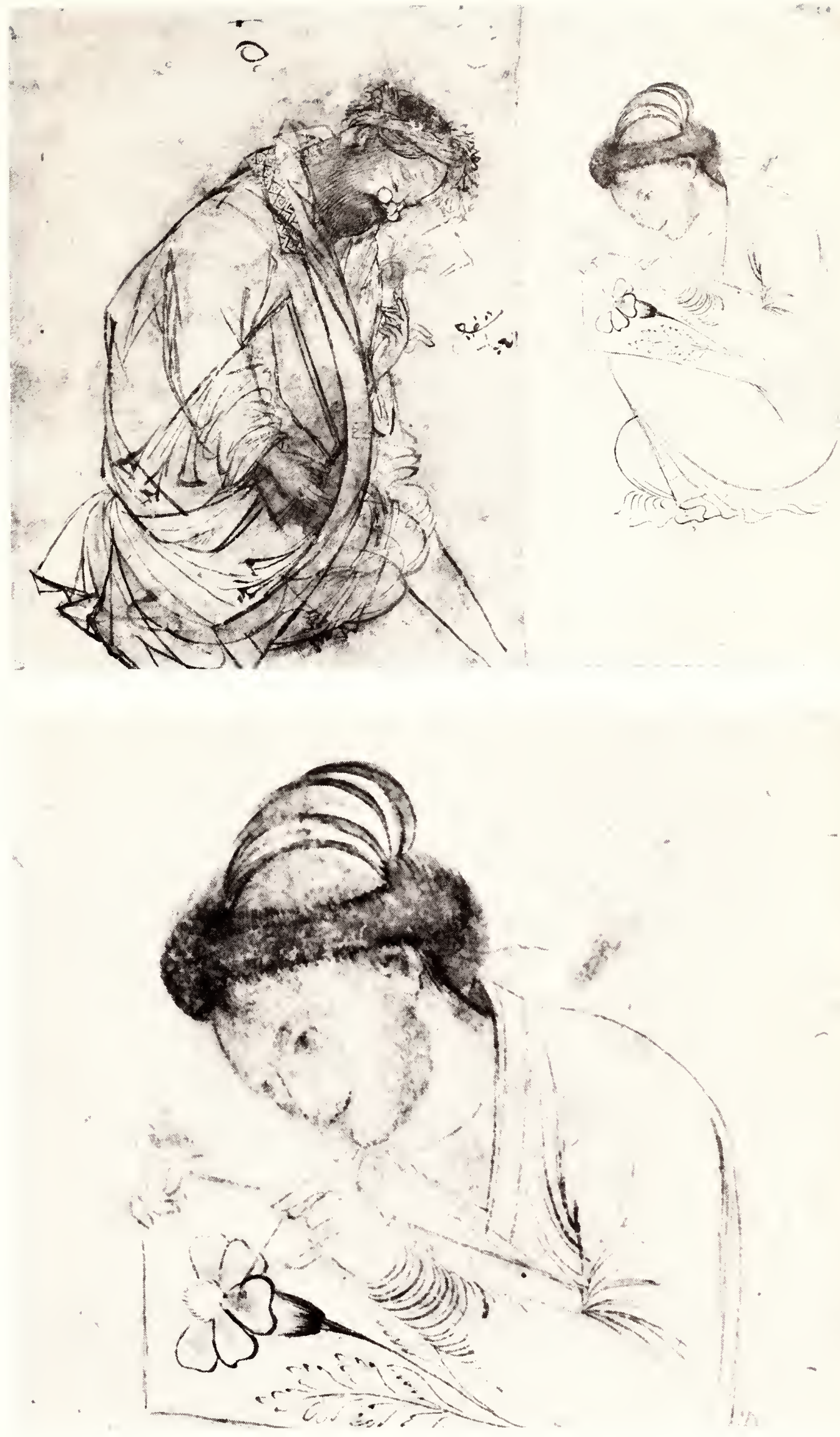
48. Old Man Leaning on a Staff From the Riza-i Abbasi Album Iran, Safavid period, mid-17th

century

Red line on paper

$11.6 \times 7.9 \mathrm{~cm} .(49 / 16 \times 31 / 8 \mathrm{in}$.

53.40

This unfinished drawing portrays a bearded man in a landscape, his hands held high as if leaning on a staff which has been omitted.

The fine brushwork in the representation of the figure and the hills in the background suggest that the artist was a close follower of Riza. His indebtedness to his teacher's brushwork is particularly noticeable in the agitated strokes around the edges of the stole and the turban
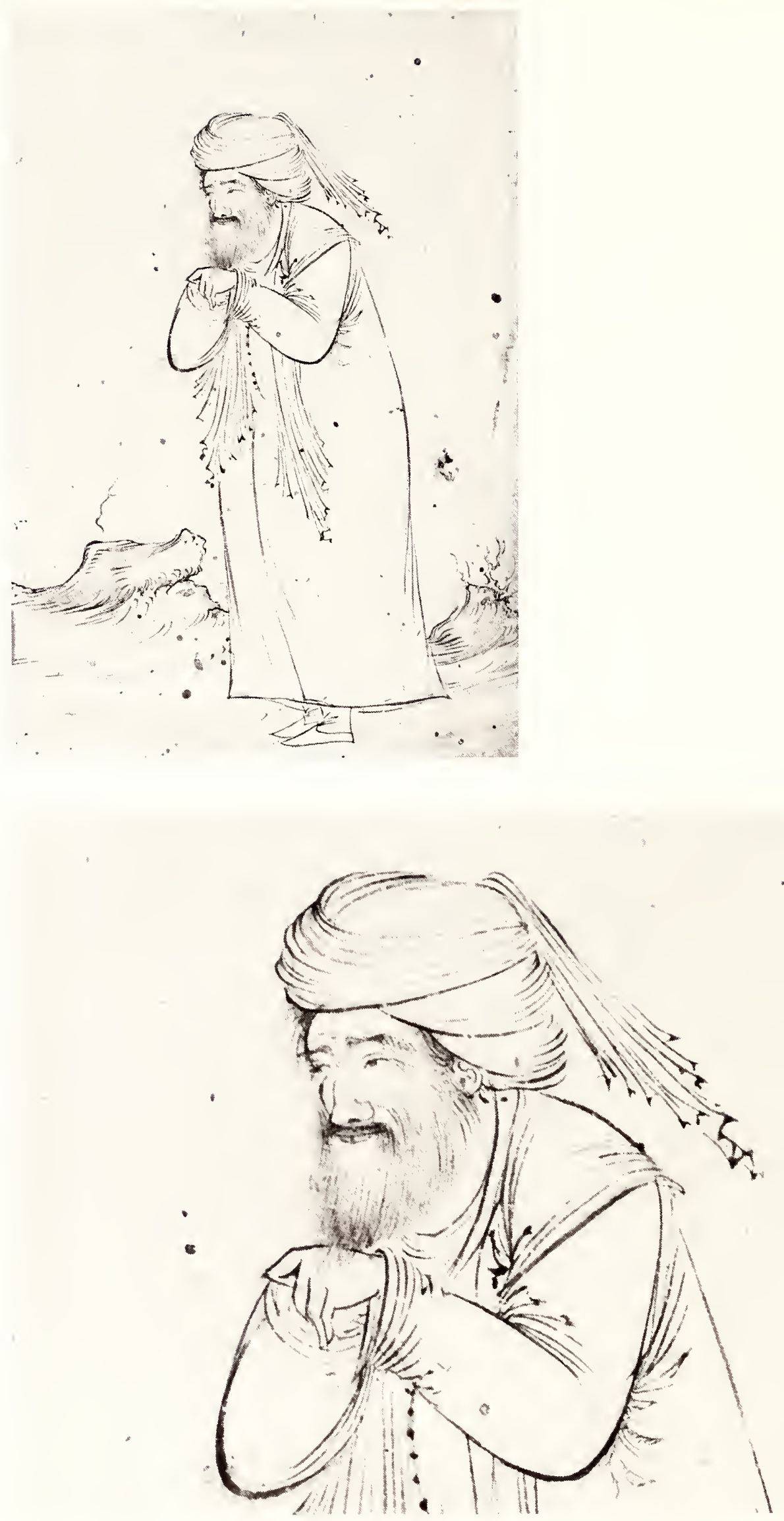


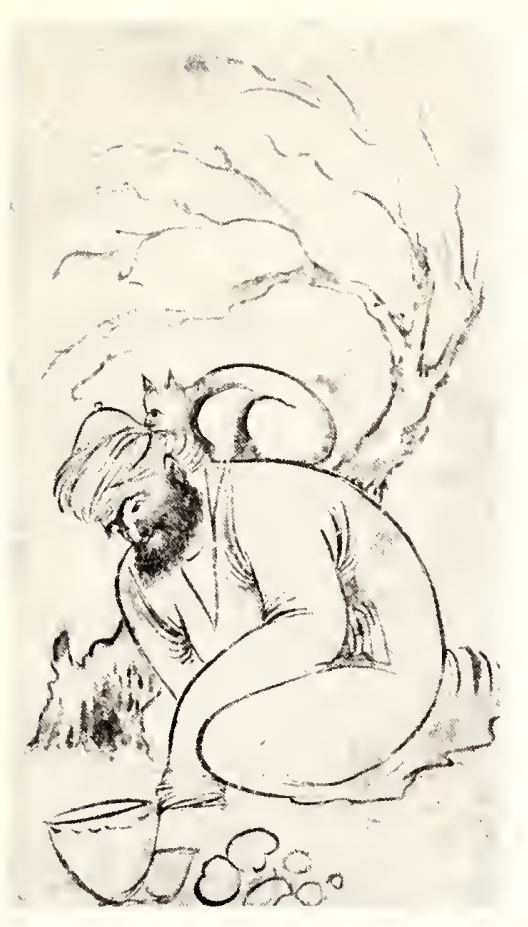

49. Dervish with a Cat

From the Riza-i Abbasi Album Iran, Safavid period, mid-17th century

Black line on paper $9.2 \times 5.1 \mathrm{~cm} .\left(3 \frac{3}{8} \times 2 \times 2\right.$ in. $)$ 53.31

This drawing, which depicts a dervish seated in front of a tree with a large cat perched on his back, characterizes the production of the school of Isfahan. The bearded figure wears a rounded cap under his turban and a longsleeved garment, the cuffs of which extend over his hands. Two bowls and several pieces of fruit appear in the foreground.

The dervish bends over under the weight of the cat; his movement is counterbalanced by the tree trunk which extends in the opposite direction and is repeated by the barren branches. The rounded mass of the figure is contrasted by the sketchy and linear execution of the background.

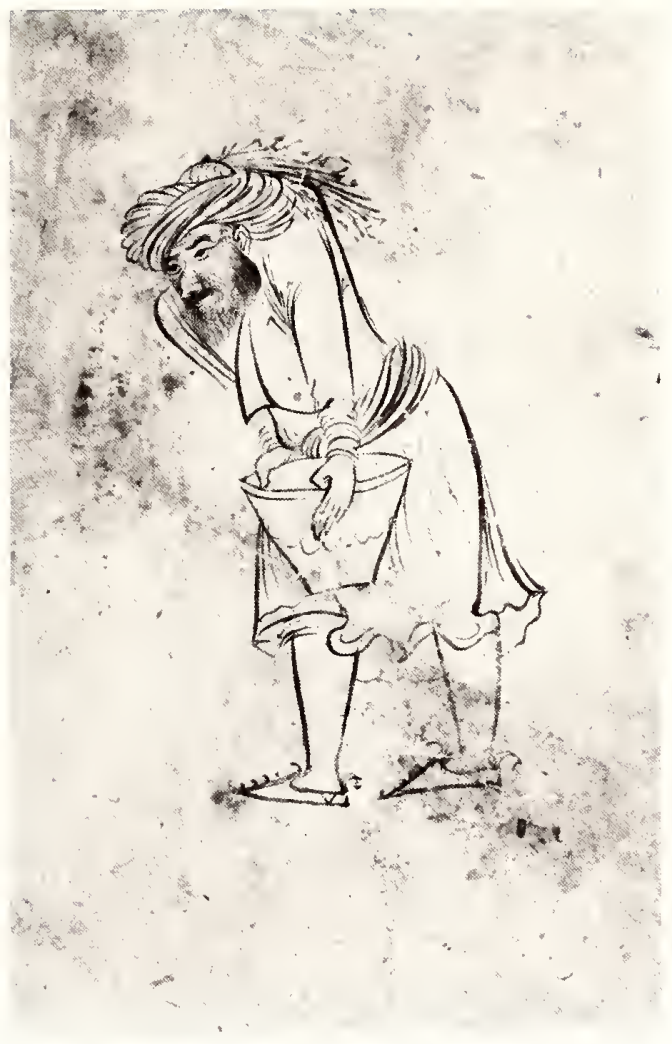

50. Hunchback with a Bowl From the Riza-i Abbasi Album Iran, Safavid period, mid-17th century

Black line on paper

$10.8 \times 6.7(41 / 4 \times 25 / 8$ in. $)$

53.32

The drawing portrays a bearded hunchback who struggles with a large bowl, straining to lift it. By placing the image against an empty background, the artist accentuated the pathos of the deformed figure who has reconciled himself to hardship and has accepted his fate.

Riza and his followers frequently executed studies of humble workmen and poor people, reflecting a social strata which differed considerably from the upper classes. 
51. Young Man Holding Flowers From the Riza-i Abbasi Album Iran, Safavid period, mid-17th century

Black line on paper

$15.1 \times 8.5 \mathrm{~cm} .\left(5^{15 / 16 \times 33 / 8}\right.$ in $)$ 53.22

This example represents an elegant courtier, wearing an elaborate curban adorned with feathers and attired in a coat embroidered with animals and landscape motifs. The figure kneels on the ground and holds a spray of flowers. A tapered penknife hangs from his sash into which a handkerchief is tucked.

This type of pose was almost a formula used by artists in portraying the young dandies of the court. Similar single-page drawings and paintings were executed in the 16th century and continued to be produced up to the end of the Safavid period (nos. 16, 19, 20 and 32 ).

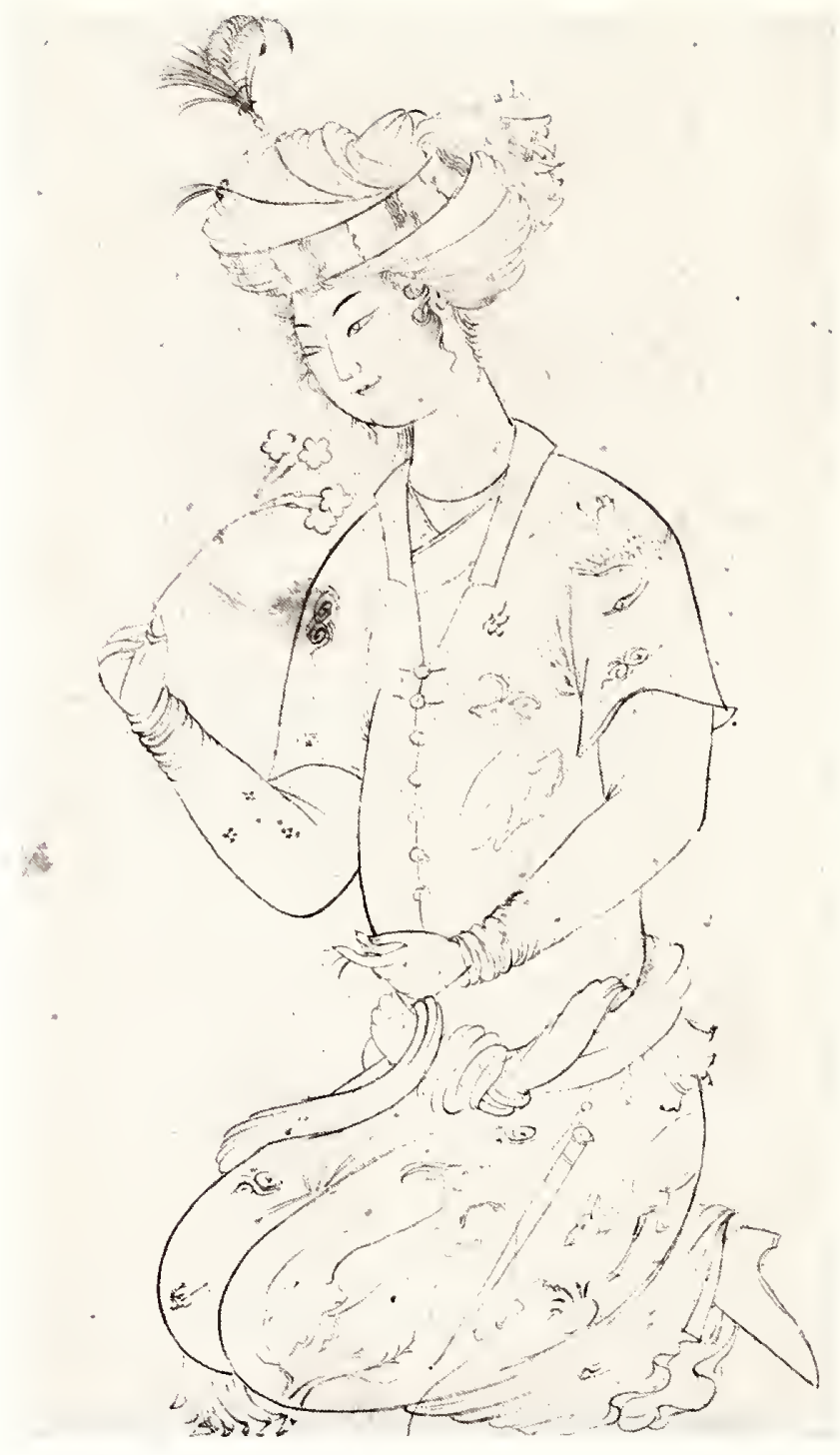


52. Cloth Merchant

From the Riza-i Abbasi Album Iran, Safavid period, mid-17th century

Black line on paper

$17.1 \times 11.5 \mathrm{~cm} .(63 / 4 \times 4 \%$ in $)$ 53.43

In addition to representing workmen, shepherds, wandering dervishes and courtly figures, the drawings of the Isfahan school also portray the wealthy middle classes. This crisply drawn example depicts a bearded merchant kneeling on a carpet, holding a length of cloth. Other pieces of fabric lie on the ground together with the tools of the merchant's trade-a pair of scissors, a pen case and inkwell, several sheets of paper and some reed pens.

The varying thickness of line lends a feeling of weight and volume to the figure; rapidly executed strokes define the drapery and present a contrast between the volumes and voids in the composition. The brush strokes on the turban, shawl, cuffs and samples of cloth are particularly well rendered, revealing the hand of a highly competent artist.

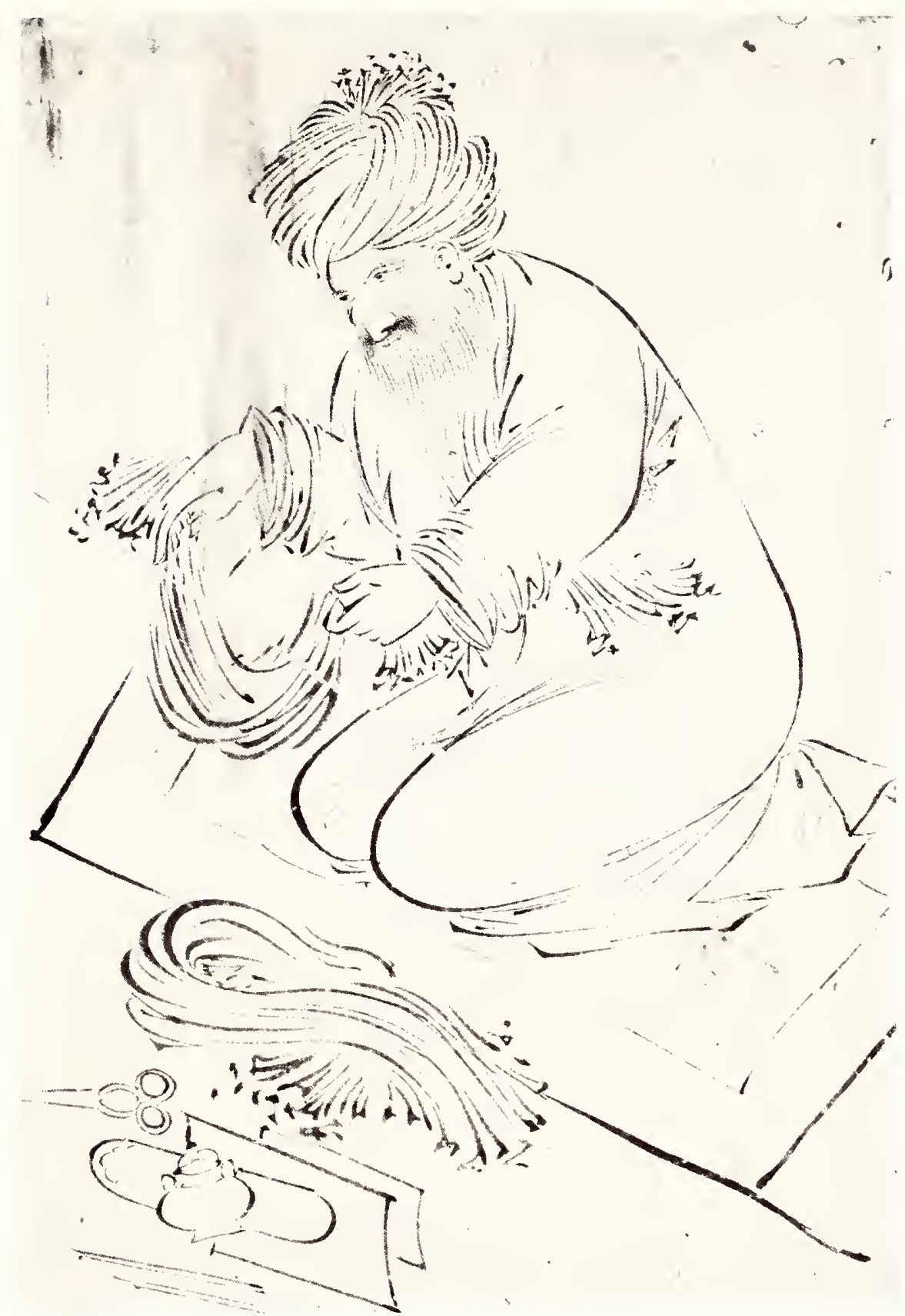


53. Old Man Riding a Zebu From the Riza-i Abbasi Album Iran, Safavid period, mid-17th century

Black line on paper

$12.2 \times 9.9 \mathrm{~cm} \cdot\left(4^{13} / 1 \mathrm{c} \times 37 / 8 \mathrm{in}.\right)$ 53.13

One of the most outstanding drawings in the album represents a bearded man riding a zebu. The figure is executed in soft and delicate strokes which present only the essential parts of the form. Similar rapidly applied strokes define the animal and the landscape in the background

The butky animal striding at a slow pace and the elderly figure bent with age are portrayed with sensitivity as well as naturalism. The scene projects timelessness and harmony among man, beast and nature

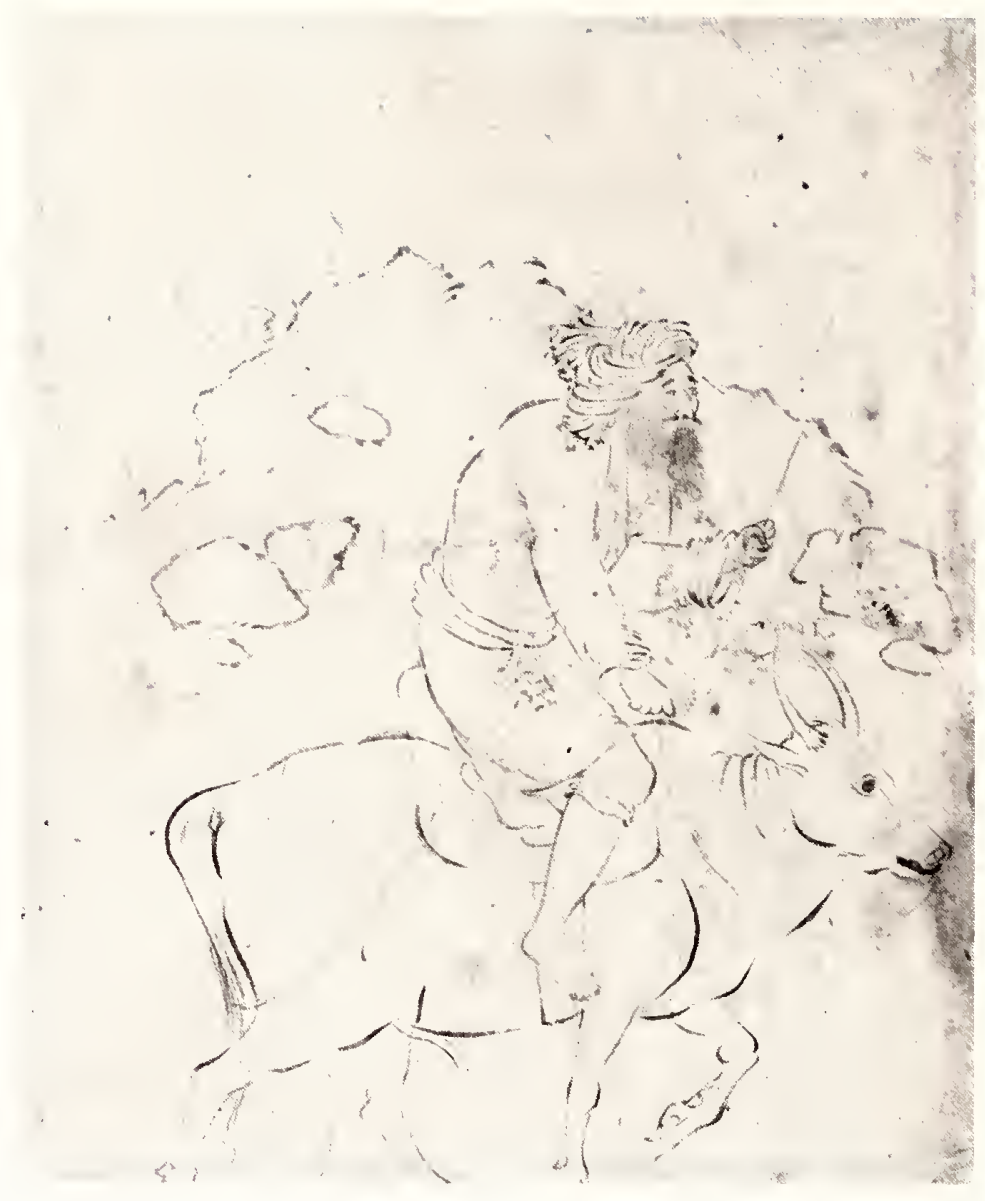


54. Woman with Flowers (left) Woman with a Scarf (right)

From the Riza-i Abbas Album Iran, Safavid period, mid-17th century

Black line on paper

Left: $8 \times 7.1 \mathrm{~cm} .\left(31 / 8 \times 2^{13 / 16}\right.$ in. $)$ Right: $6.1 \times 5.6 \mathrm{~cm}$.

$(27 / 16 \times 23 / 16$ in. $)$

53.58

The two studies of women are very close in style and were possilly executed by the same hand. The sketch on the left represents a young woman holding flowers; her flowing tresses are partially covered with a cap which has a peaked front and ribbons at the back; her dress has a low collar exposing an undershirt and several beaded necklaces.

In the companion drawing the head of the woman is covered with a cap worn over a scarf with locks of hair framing her face; a pin adorns the cap. A flower is tucked into the headdresses of both ladies.

The figures represent the ideal female beauty of the age, with a round face, small puckered lips and almond-shaped eyes framed by heavy eyebrows which join together at the bridge of the straight nose.

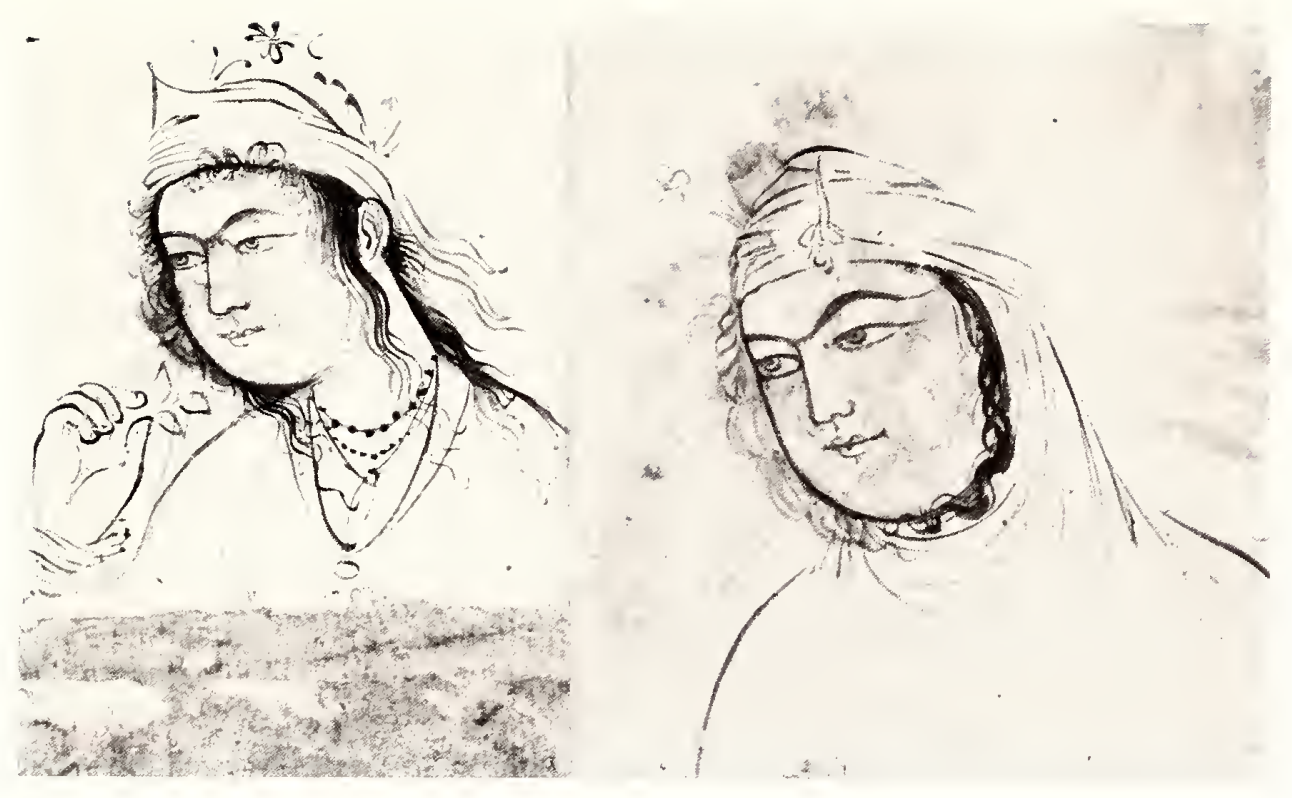

89 
55. Old Man and Youth From the Riza-i Abbasi Album Iran, Safavid period, mid-17th century

Black line on paper $12.2 \times 12.6 \mathrm{~cm} .\left(4^{13 / 16} \times 5 \mathrm{in}.\right)$ 53.42

Among the works of the period are several drawings with erotic implications and earthy humor of the type which were favored by Riza. This sketch represents a lecherous old man making an indecent and highly suggestive gesture to a youth. The ground between the personages is filled with rapidly executed rocks, clusters of leaves, flowers and fruit.

The incomplete head of a man which appears in the middle of the scene must be a later addition; his wide-eyed and startled expression is possibly meant to be a comment on the assignation that is about to take place.

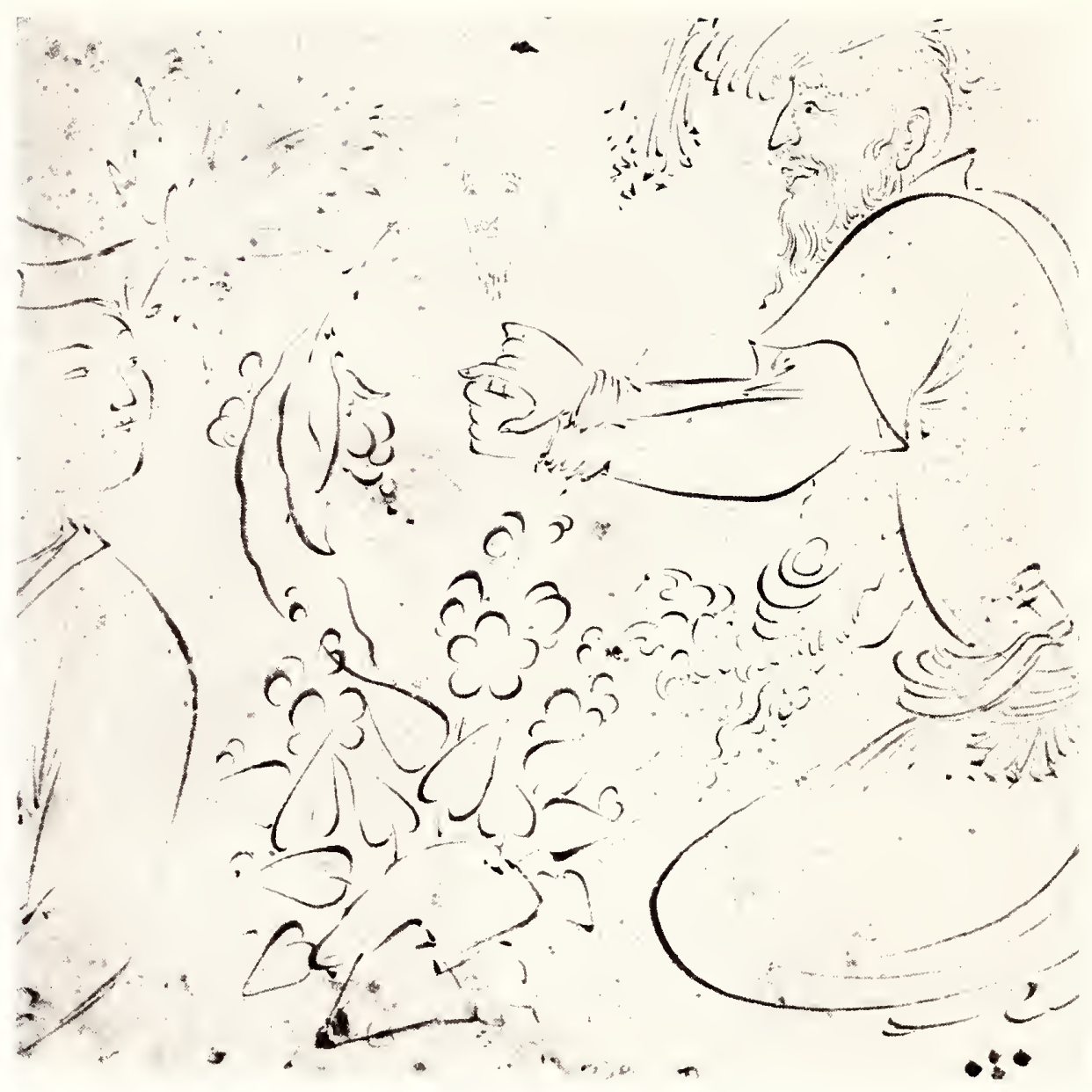




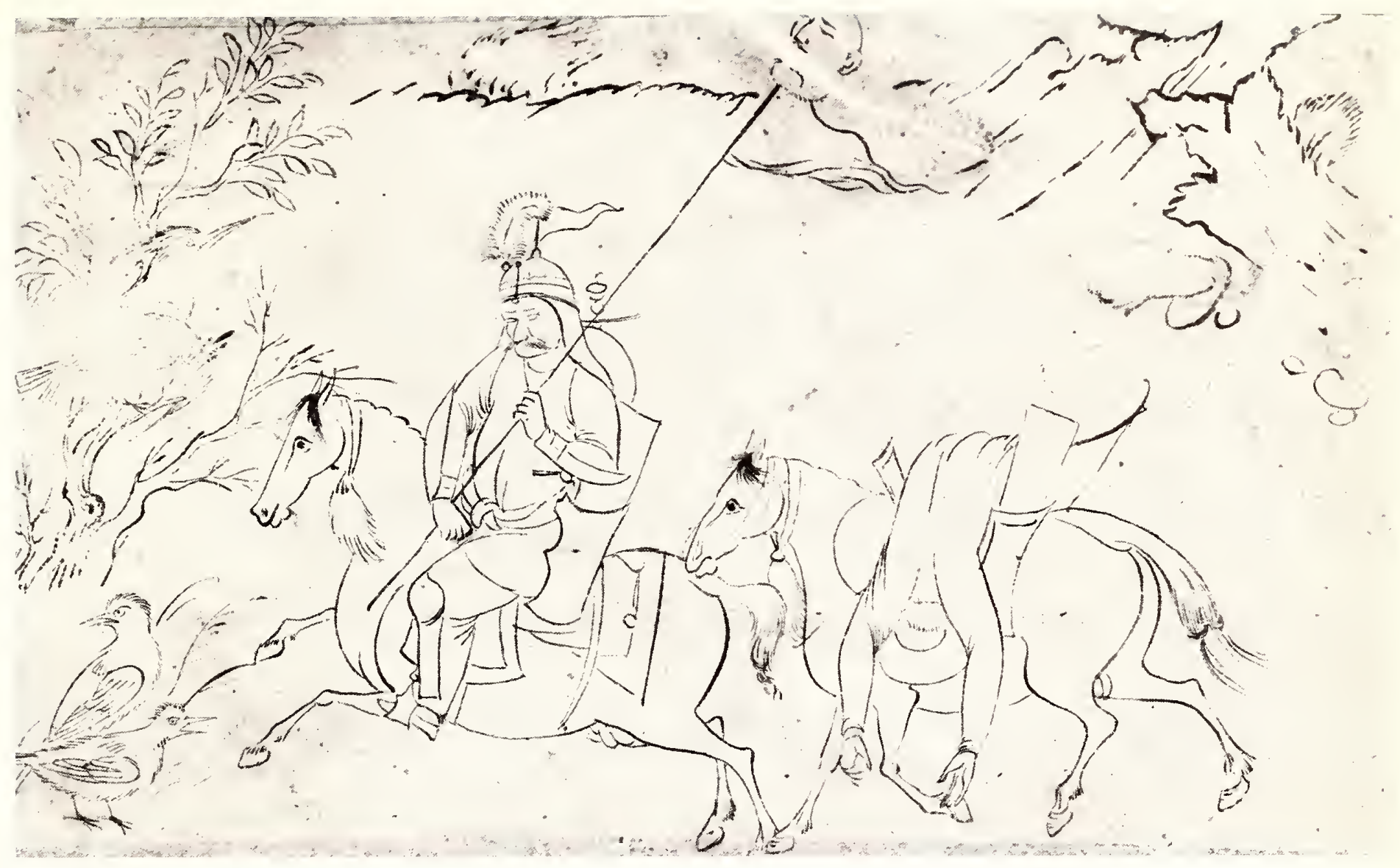

56. Rider with Decapitated Enemy

From the Riza-i Abbasi Album

Iran, Safavid period, mid-17th

century

Black line on paper

$9.6 \times 15.8 \mathrm{~cm} .\left(3 \frac{3}{16} \times 61 / 4 \mathrm{in}.\right)$

53.47

This example, with fine perforations following the outlines of the drawing, was used as a stencil. The drawing depicts a mounted warrior leading a horse over which the body of his slain enemy is thrown. The warrior is in full armor: he wears an elaborate helmet decorated with a plume and banner, carries his shield and weapons on his back and holds a long spear on top of which is the severed head of the enemy.

The hills and vegetation in the background imply that the scene takes place in a mountainous and wooded area. The two pairs of oversized birds on the left seem out of place and must have been added later. This type of bird is depicted on several other folios of the album (nos. 35, 45, 57 and 58). 
57. Landscape with Animals From the Riza-i Abhasi Album Iran, Safavid period, mid-17th century

Black and red lines on paper $18.4 \times 8.3 \mathrm{~cm} .(71 / 4 \times 35 / 16 \mathrm{in})$ 53.35

The densely packed scene depicts a variety of wild animals and birds peacefully coexisting in nature. In the foreground, a couple of wild goats drink from the stream in which ducks and fish swim. Behind them are a pair of foxes and a family of lions with the female suckling one cub while playing with the other. A number of birds are perched in the branches of the two trees on the lower right and upper left with more swooping down from the sky

The animals are drawn in black and the landscape elements are rendered in red. The birds on the lower and upper right portion appear to have been corrected using red over black lines. The drawing may have been a sketch for a painting, similar to the next example
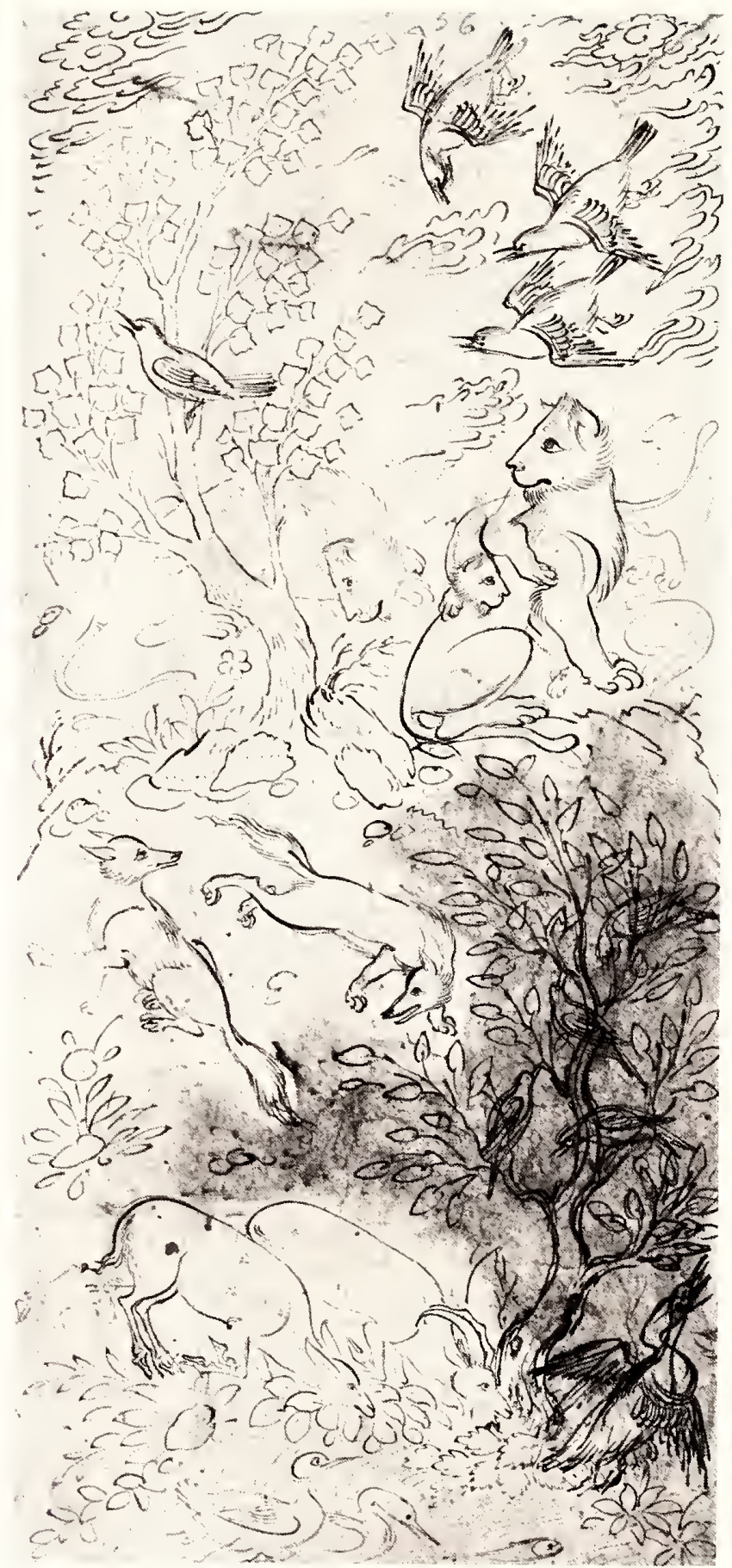
58. Landscape with Animals From the Riza-i Abbasi Album Iran, Safavid period, mid- $17 \mathrm{th}$ century

Black and red lines on paper $18.8 \times 9.4 \mathrm{~cm} .\left(73 / 8 \times 3^{11 / 16 \mathrm{in} .)}\right.$ 53.36

This drawing, which also represents animals in a landscape, has been pierced and was used in stenciling. In contrast to the previous example, the scene contains fewer animals shown in combat A fox in the foreground has caught a terrified crane by its legs while its mate dives down to attack the intruder. The movements of the cranes-one trying to ascend whereas the other

descends - are repeated by the clouds in the sky and the leaves of the tree. The antagonistic behavior of the prey and predator has even affected the birds on the right which appear to be quarreling.

With the exception of one branch, which is drawn in red, the entire scene is executed in black line.

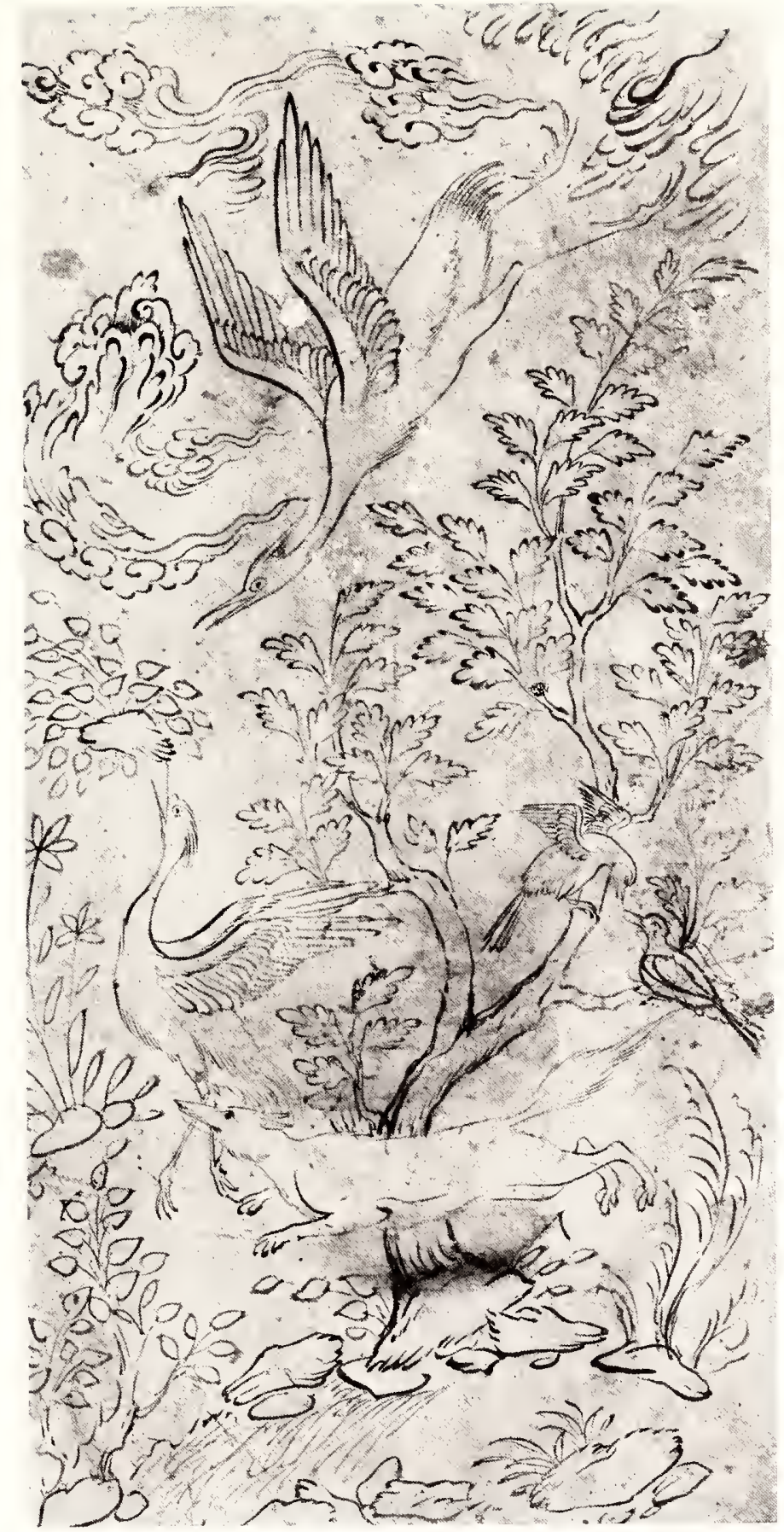




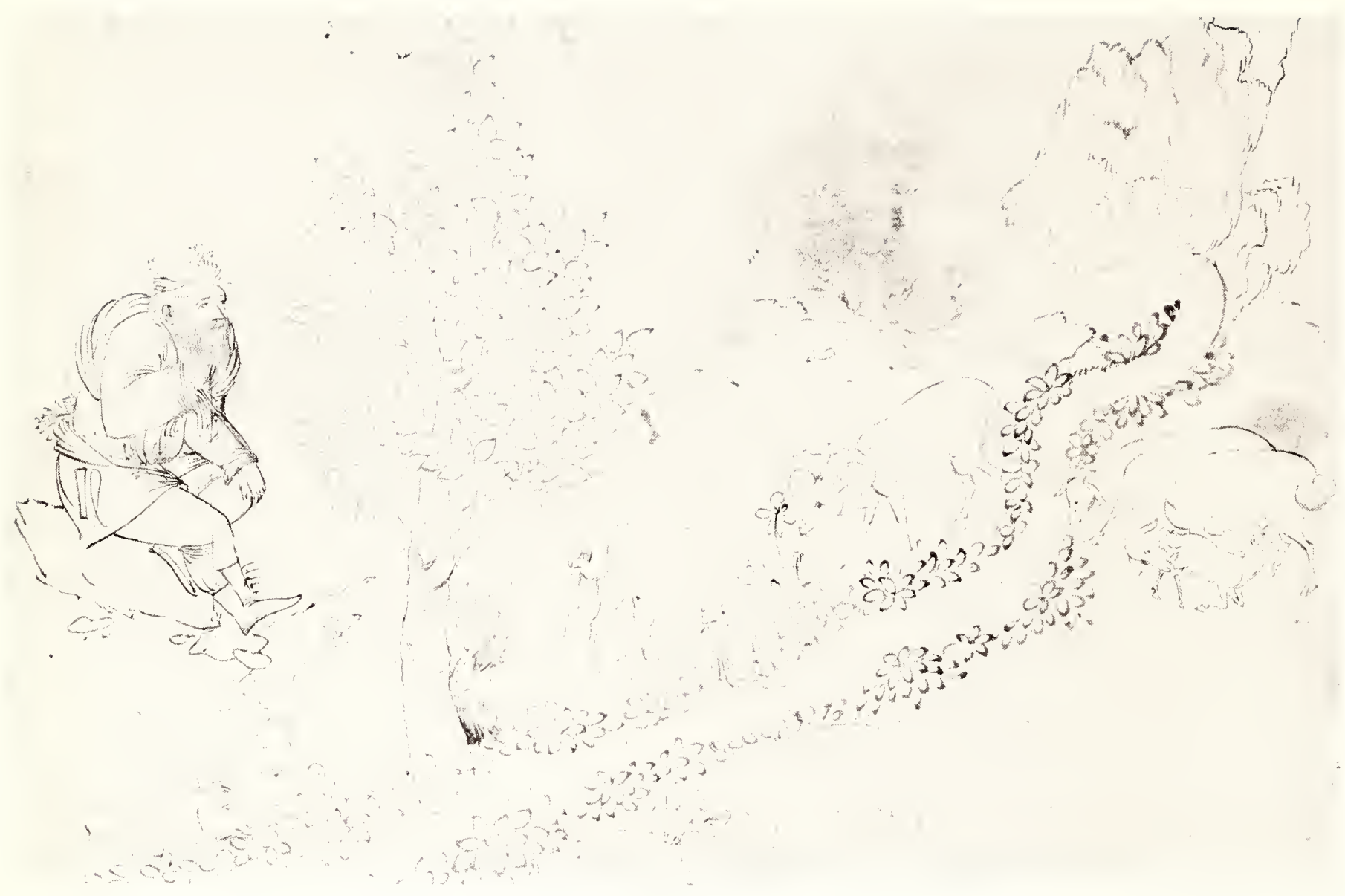

59. Shepherd with His Flock From the Riza-i Abbasi Album Iran, Safavid period, mid-17th century

Red line on paper $12.2 \times 18.4 \mathrm{~cm} \cdot\left(4^{13 / 16} \times 71 / 4 \mathrm{in}\right)$ 53.49

The drawing recalts the theme represented on a previous example which was executed with polychrome tints (no. 44). This scene, drawn in red, depicts a shepherd seated on a rock while his flock grazes along the banks of a stream which springs from the mountains on the upper right and flows diagonally across the folio. A dense strip of vegetation grows along the banks of the stream and a foliated tree appears on the left The animals are rendered with naturalism, several ewes suckling or tenderly licking their lambs. The male members of the flock are shown with large horns and include a ram and goat

The weary shepherd leans on his staff, enjoying the peace and tranquility of the setting. An impression of external solitude and

harmony permeates the scene, resembling the drawing of the old man riding a zebu (no. 53). 
60. Sketch for Yusuf va Zulaykba From the Riza-i Abbasi Album Iran, Safavid period, mid-17th century

Black line on paper

$19.8 \times 10.4 \mathrm{~cm} .\left(7^{13 / 16} \times 41 / 8 \mathrm{in}.\right)$ 53.37

The sketch depicts two episodes from the story of Yusuf and Zulaykha. On the top is youthful Yusuf, or Joseph, bound in chains, kneeling on a carpet with a flaming halo engulfing his head. Below him are two other prisoners, also bound in chains attached to a ring placed around their necks; these two figures have additional shackles around their ankles. A candlestick with a burning candle placed next to Yusuf indicates the scene takes place indoors and at night.

The episode represented on the lower portion of the drawing occurs several years later and portrays Yusuf as a middle-aged man. He is sitting in front of a gate, holding a sword while his quiver, bow and shield are placed in the background. The old woman approaching him is Zulaykha who tried so hard to seduce Yusuf in his earlier days Two other women witness this reunion.

The drawing is perforated and must have been used to transfer the design to a manuscript illustration

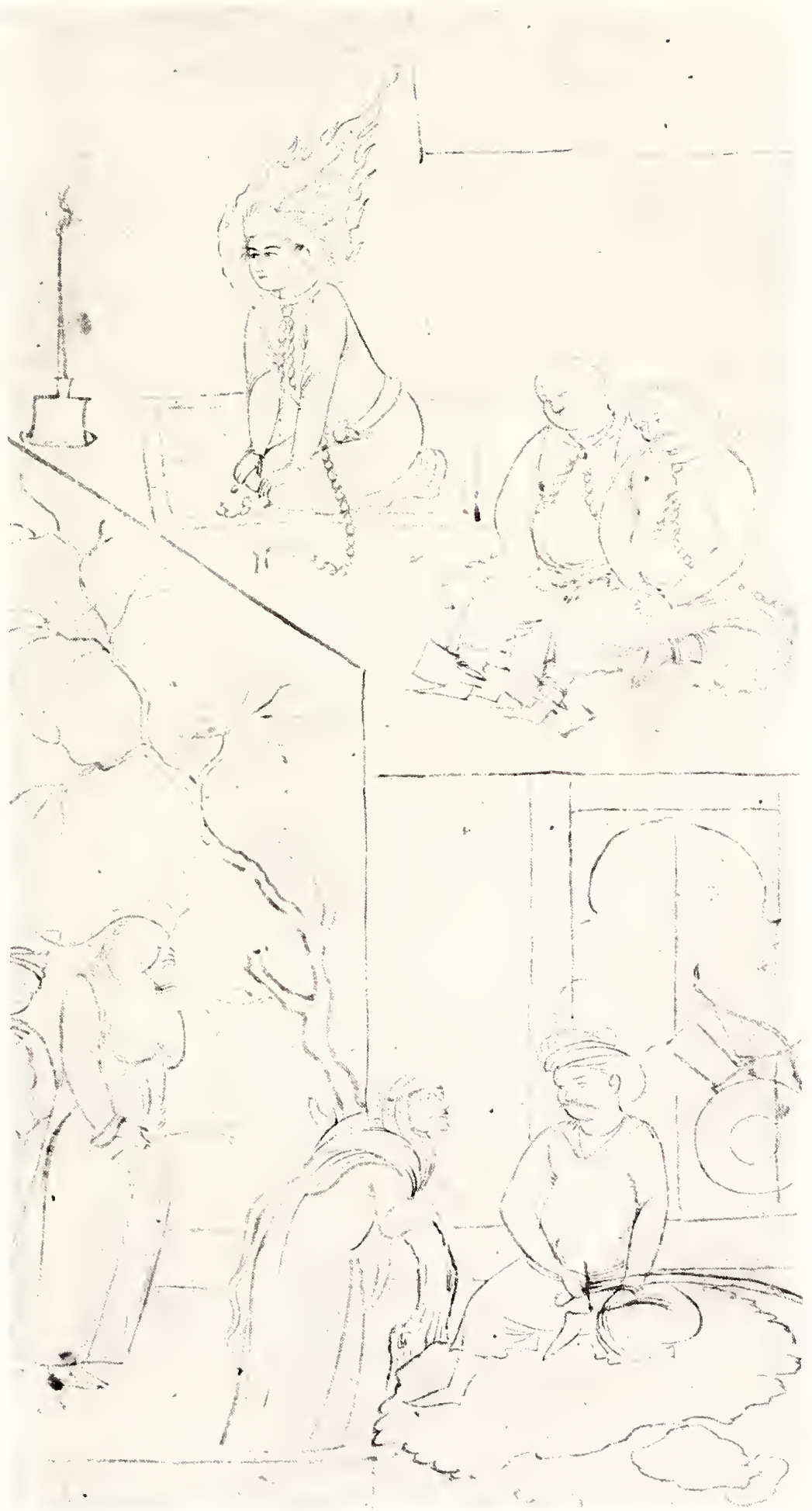





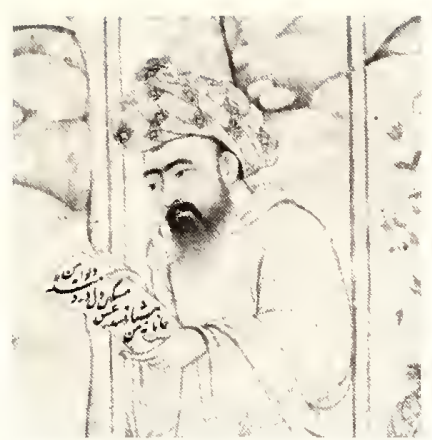

\section{Drawings from India}

Drawings executed in India between the 16th and 18th centuries reveal several independent schools in the Deccan and Rajastan in addition to the art of the Mughal court. Mughal painting, influenced by the Safavid traditions during its formative years, soon formed a synthesis of foreign and native elements, creating an indigenous style which had an impact on the development of both Deccani and Rajput schools.

Similar to the tradition in Iran, Mughal drawings are found in the marginal decorations of imperial manuscripts as well as on single sheets incorporated into albums. The most spectacular examples of marginal drawings appear in the albums compiled for Jahangir which combine European themes with local figures and scenes. Due to the fascination with Christianity on the part of the emperors and the colonization of Goa by the Portuguese in the beginning of the 16th century, Western subjects were frequently depicted in the Mughal court.

The Mughal emperors were equally fascinated with historiography; the early rulers, including Babur, Jahangir and Shah Jahan, wrote their own memoirs, while others, like Akbar, commissioned court biographers to document their lives. Many of these biographies were illustrated and as a result of this preoccupation with contemporary history, portraiture became the most popular form of art. Mughal albums contain a great number of portraits, many of which were executed during the lifetime of the subject. The provincial courts followed the traditions of the capital, producing studies of single figures or courtly scenes to be included in albums.

Portraiture was also popular among the Muslim sultans of the Deccan and the Rajput princes of Rajastan and Punjab. The court studios of the Deccan produced album drawings depicting single figures and ceremonial or festive events as well as Christian and Hindu subjects.

The Rajput artists were primarily involved in representing religious themes, particularly the romance of Krishna, the most revered of the Hindu gods. 


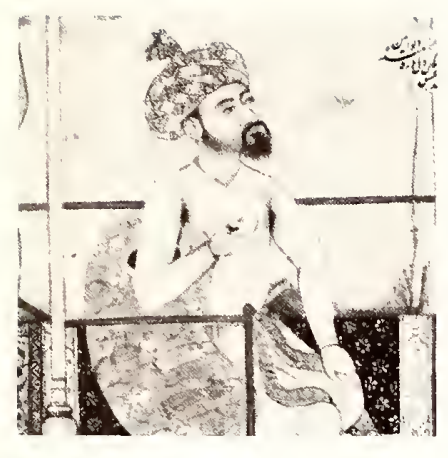

\section{Mughal School}

Islam was introduced to India in the beginning of the eighth century with the conquest of the lower Indus Valley by the Arabs. During the ensuing centuries, several Muslim dynasties controlled various regions of the land, establishing courts in Delhi, Bengal, Kashmir, Gujerat and the Deccan. The Rajput princes of Hindu faith were autonomous in northwestern India, governing in Rajastan and Punjab. These states remained independent until the rise of the Mughal dynasty (1526-1858) which succeeded in uniting the great subcontinent of India under one regime.

Babur (1526-30), the founder of the dynasty, was an outsider like the other Muslim rulers of India and was born in Ferghana, now in Soviet Turkestan. He descended from Timur on his father's side and was related to Genghiz Khan through his mother. In 1504 Babur swept through Afghanistan, capturing Kabul and Ghazna; within the following two decades he was the master of northern India. He defeated the Muslim sultan of Delhi and the Hindu raja of Gwalior in 1526, laying the foundation of the Mughal Empire. The fascinating birth of the new state is narrated in his memoirs, the Vakiat-i Baburi which was originally written in Turkish, his native tongue, and later translated into Persian as the Babumame.

The newly established dynasty's problems began soon after Babur's death. The reign of Humayun (1530-56), was constantly jeopardized by his ambitious brothers and the Afghans who seized Bengal and forced the emperor into exile. Humayun fled to Iran in 1544 and was welcomed by Shah Tahmasp. The emperor remained in the Safavid court for 10 years, undertaking periodic campaigns to regain his lands with the aid of the Safavids. In 1554 he recaptured Agra and Delhi, defeating his treacherous brothers and the troublesome Afghans.

Humayun's residence in Shah Tahmasp's capital had a considerable impact on the development of Mughal art. The emperor was exposed to the works of the Safavid artists and developed a great admiration for the art of painting. He invited to India two renowned artists from Tabriz, Mir Sayyid Ali and Abd al-Samad, who became highly influential during the formative years of the Mughal school of painting.

During the reign of Akbar (1556-1605), the golden age of India, the empire was reestablished and Mughal art reached its apogee. Akbar was a genius in administrative matters and succeeded in keeping his empire intact by employing Rajput princes in the government. He also married a Hindu princess 
and formed a strong family bond between the Rajputs and the Mughals. Akbar even advocated a new religion, the Divine Faith, which encompassed all beliefs, and attempted to keep his empire undivided.

The emperor was intellectually inquisitive and extremely liberal, welcoming all talented men to his court. In 1563 he built Fatehpur Sikri, the City of Victory, where Indians of all backgrounds-Jain, Hindu, Muslim, Zoroastrian and Christian-flocked to his court and enjoyed discussions which lasted throughout the night. Akbar had Hindu religious texts, such as the Mababharata and Ramayana, translated into Persian, the court language, and compiled a vast library which included manuscripts on all topics.

The emperor had a special liking for illustrated books and established a painting studio comprised of more than 100 artists under the direction of Mir Sayyid and Abd al-Samad. ${ }^{50}$ One of the earliest illustrated manuscripts of his reign, the Tutimame (Tales of a Parrot), executed around 1560, reveals the eclectic background of the artists with Hindu and Muslim painters from Rajastan, Deccan and Central India working closely together. ${ }^{51}$

Akbar was particularly interested in history and commissioned a number of illustrated historical works, including the monumental Hamzaname, the history of Amir Hamza, the uncle of the Prophet Muhammad; ${ }^{22}$ and Baburname and Akbarname, biographies of the two founders of the Mughal Empire. ${ }^{53}$ Due to Akbar's fascination with historiography, Mughal painting excelled in the documentation of contemporary events and personages. The most popular theme was portraiture in which the subject was represented with an almost photographic likeness. The court artists also produced albums with single-page paintings and drawings depicting genre scenes, animal studies and portraits (no. 61).

The emperor's reign was not without family problems. His son, Prince Salim, later named Jahangir (Conqueror of the World), was impatient to rule and in 1600 marched to the capital from Allahabad, where he was serving as the governor. Although a showdown was prevented and Akbar forgave the prince, father and son were never fully reconciled.

Jahangir (1605-27), who ascended the throne after the death of his father, continued Akbar's interest in painting but had a completely different taste. He was a true connoisseur and preferred soft and delicate paintings in contrast to the vigorous and dramatic style supported by his father. Jahangir favored single-page paintings which were compiled into 


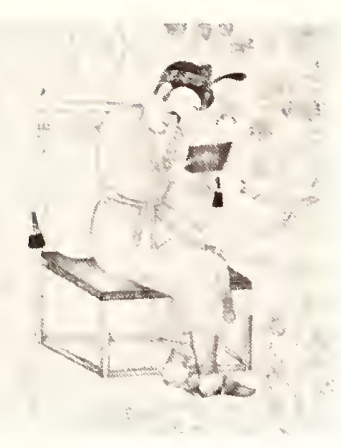

murakkas, or imperial albums. The contents of these albums represent the emperor's taste and interest, showing a predominance of Iranian, Mughal and Deccani paintings as well as European prints which were frequently copied by the court artists.

Two of Jahangir's most celebrated albums are in Tehran and Berlin with a number of detached folios owned by diverse European and American collections. The Tehran volume, known as the Murakka-i Gulshan (Gulshan Album) contains 92 folios and is in the Imperial Library of the Gulistan Palace. According to the dated examples, it was compiled between 1599 , when Jahangir was still a prince governing Allahabad, and 1609, slightly after his accession. ${ }^{54}$ The second volume, owned by the Staatsbibliothek in West Berlin, has 25 folios and is datable between 1608 and 1618.55

The albums were compiled in a carefully organized format: each folio contained an illustration on one side and a sample of calligraphy on the other; when the folios were collated, two pages of illustrations faced one another and were followed by two pages of calligraphy; the wide margins around the paintings were decorated with arabesques, whereas those around the text had figural drawings. The figures in these drawings were rendered in color or tints, placed against a landscape executed in gold. Some of the drawings contain the signatures of the best painters of the period, as well as portraits of artists at work and themes copied from European prints. ${ }^{56}$ The Freer Gallery of Art owns four folios from the earlier Jahangir album which are included in the exhibition (nos. 62-65).

The painters of Jahangir's studio produced a great number of single-page paintings and drawings which were made for other less sumptuous albums (nos. 66-69). One of the drawings bears an attribution to the most renowned artist of the court, Abu'l-Hasan, who was given the name of Nadir al-Zaman (Wonder of the Age) by Jahangir (no. 68).

Abu'l-Hasan was the son of Aka Riza, a well-known painter who worked in the court and executed some of the drawings in the Gulshan album. ${ }^{57}$ Abu'l-Hasan was the favorite artist of Jahangir and portrayed his patron in several album paintings ${ }^{58} \mathrm{He}$ continued working in the studio after the death of Jahangir and was employed under Shah Jahan. Although other drawings attributed to Abu'l-Hasan are not known, there is no reason to doubt that he also worked in this genre, imitating his father's technique.

Jahangir's son Shah Jahan (1628-58) had spent his early years in Akbar's court and inherited his family's enthusiasm for the 


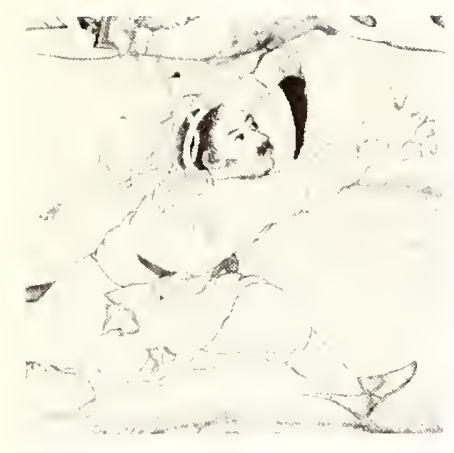

arts. Like his father, he was the son of a Rajput princess and highly devoted to his wife, Mumtaz Mahal, for whom the Taj Mahal was built. Shah Jahan continued to support the activities of the artists and preferred single-page illustrations made for albums (no. 71).

Similar to the fate of his predecessors, Shah Jahan was challenged by his son, Aurangzeb, who had him imprisoned at Agra where he died in 1666. The new ruler, called Alamgir I (1658-1707), undertook campaigns to the south leading to the conquest of the Muslim sultanates of the Deccan in 1686-87. He had the poor judgment to reverse Akbar's attitude towards the Rajputs, arousing their enmity. Alamgir's policies weakened the empire, and soon after his death the Rajput princes as well as the Muslim rulers started fighting against the Mughals.

The Mughal Empire began a slow and painful decline; the state was ruled by weak and incompetent emperors and the outlying provinces gradually slipped away. The imperial studios diminished and the artists sought employment in the provincial courts (no. 72-74). In 1738-39 Nadir Shah, the founder of the Afsharid dynasty of Iran, invaded Delhi and took back the treasures of the emperors (no. 75). The Mughal Empire came to an end in 1858 when the last emperor was exiled to Burma by the British who had extended their power into India.

The traditions established by Akbar, both in administrative and cultural spheres, were so strong that the empire and its arts took a long time to die. The legends of the Mughats are very much alive today, and contemporary paintings still contain vestiges of the past. 
61. Babur with Attendants

India, Mughal school, late 16th century

Black tine, gold and silver on paper; tinted with red, pink, blue, green and white

19. I $\times 12.2 \mathrm{~cm} .\left(71 / 2 \times 4^{13 / 16 ~ i n . ~}\right)$ 54.27

The drawing, which is cropped to the edge and mounted on heavy paper, represents a ruler seated on a canopied platform, attended by his court. The main personage is identified as Babur, the founder of the Mughal Empire, bearing a close resemblance to the emperor's representations in the Babumame illustrations. A youthful attendant stands behind the emperor who leans against a richly embroidered cushion while conversing with a bearded man holding a sheet of poetry. Seated in front of the platform are a pair of musicians and several courtiers with attendants. In the foreground is a pool with a pair of ducks, surrounded by various types of trees and vegetation; other trees appear in the background with a large plane tree set against the rocky mountains.

The secondary elements - the landscape features, birds, animals and details of the garments-are executed in color and gold. The carpets and cushion around the emperor are luxuriously decorated with vibrant colors accentuated by gold motifs. Silver appears in the pool and in the two channels connected to it.

The composition recalls the scheme for outdoor entertainment scenes which were frequently depicted in the paintings made in Herat and continued to be produced in the Tabriz studios. The influence of Sufavid painting was quite strong during Akbar's reign when the court atelier was under the direction of the masters from

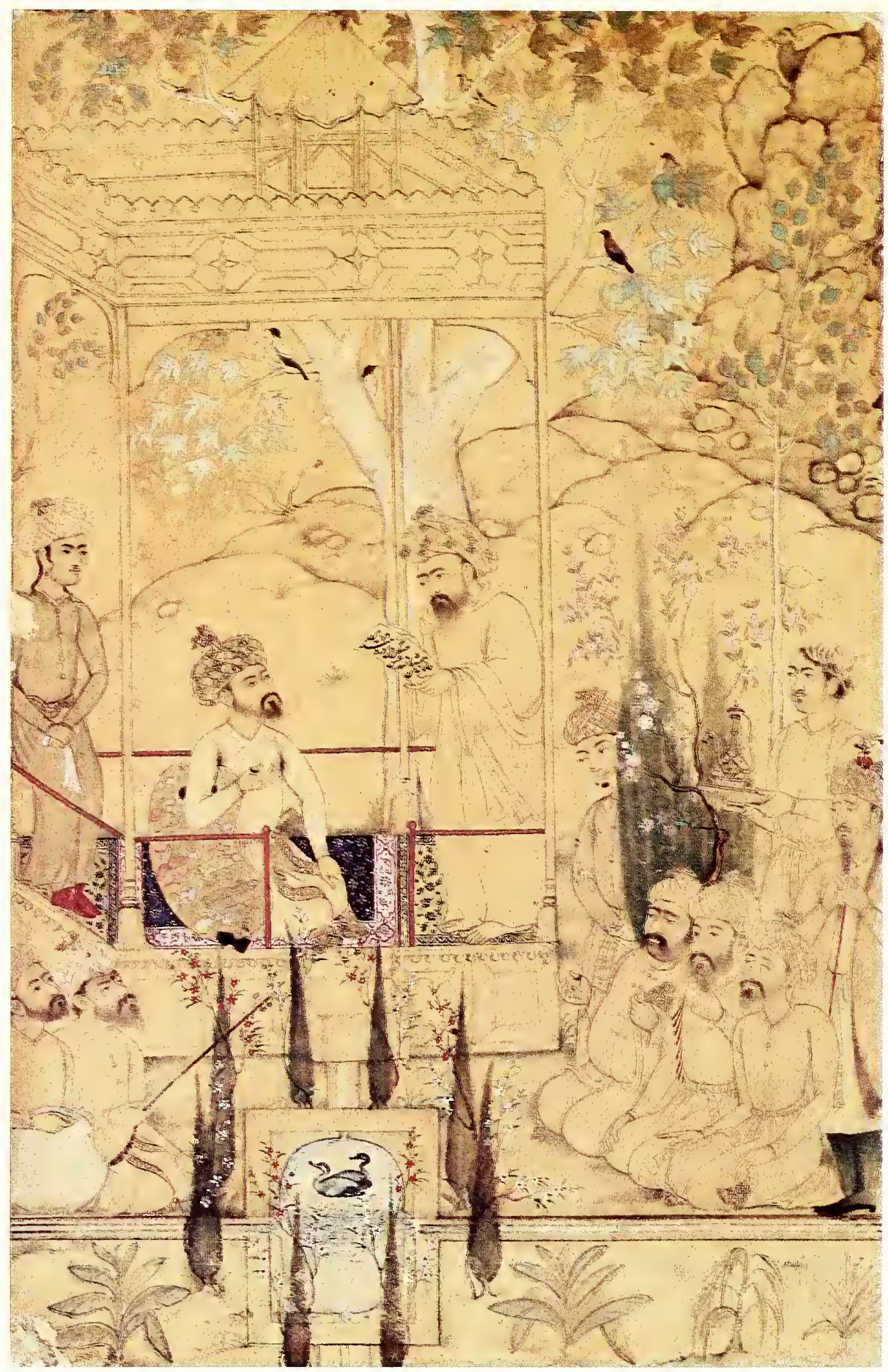


Tabriz. The same type of setting is also seen in contemporary paintings executed in the Mughal court, particularly in the Akbarname illustrations.

Although the composition is taken from Safavid art, the portrait-like representation of the figures is typically Mughal. The documenation of the lives and activities of the emperors was a major trend in the court with a number of manuscripts devoted to the reigns of Akbar and Babur. Babur had a passion for plants and gardens, which is implied by the setting of the drawing.

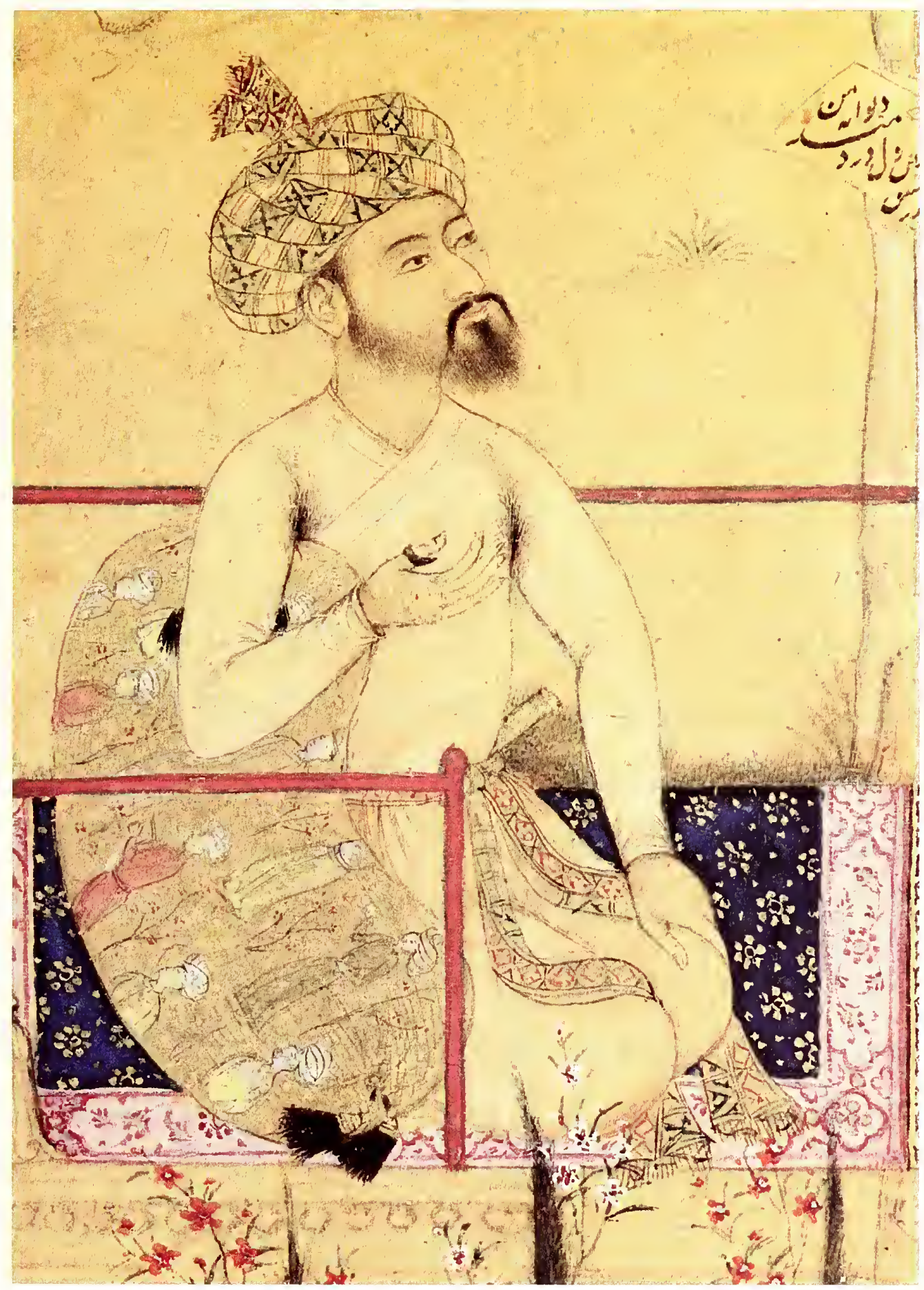


62. Five Women in a Landscape From the Jabangir Album

India, Mughal school, ca $1600-1610$

Black line and gold on paper;

tinted with red, blue, green

and white

Page: $42.3 \times 26.5 \mathrm{~cm}$

Text (including borders): $26.3 \mathrm{x}$

$15.8 \mathrm{~cm} .(103 / 8 \times 61 / 4 \mathrm{in}$.

The verso of the sheet represents a Mongol chieftain resting in the countryside, attended by his courtiers. The side on display contains four panels of nastalik calligraphy, two of which are written Ali al-Katib. This calligrapher, who is not very well known, is mentioned as having come to India from Meshhed and dying in Gujerat in 1528-29.

The marginal drawings show the influence of European prints reign of Jahangir and frequently five women, placed in a landscape executed in gold, appear to relate Christian themes; however,
since they are taken out of context, it is difficult to determine their exact iconographical significance. The figures are in one way
or another involved with books, praying before an open volume, reading or presenting bound manuscripts

Their hairstyles and garments are Western inspired, they wear
belted tunics, long skirts and billowing capes, tinted with varying tones of golden reds, blues and

The two women on the top of the red cloth, on which are a pair of golden rosewater bottles and candlesticks surrounding an open
book. The female on the right holds up a painting representing a haloed saint while her companion position opposite. The figure on the left margin stands erect, with an open book in her hand. The
pair below sit on either side of a cherub-like infant, one extending arms to receive the crawling child

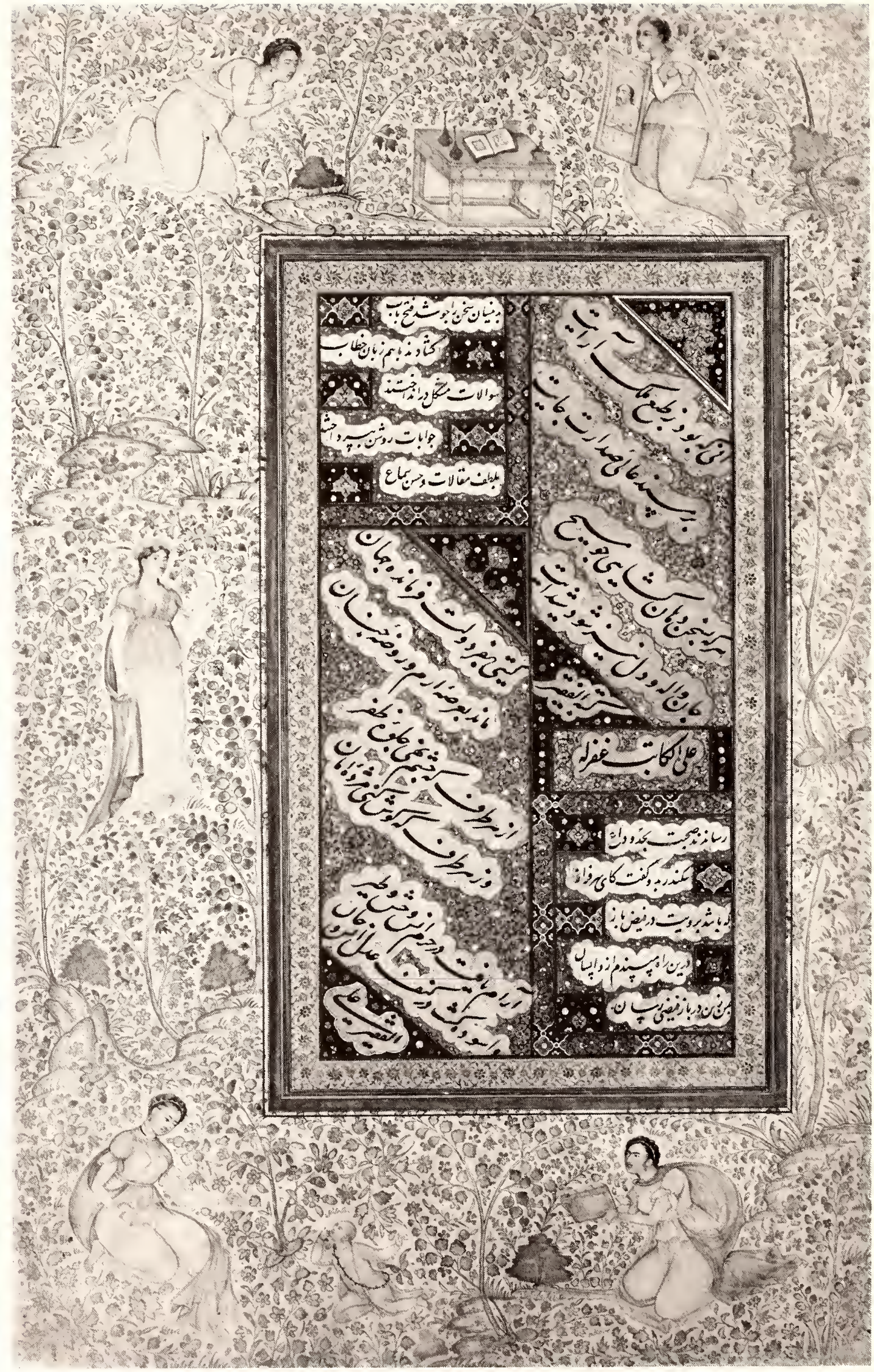


A.

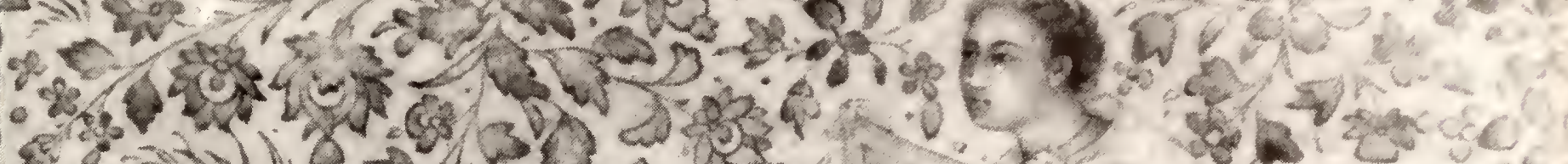

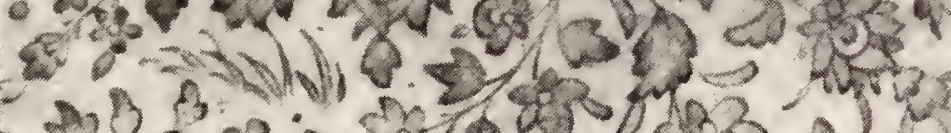

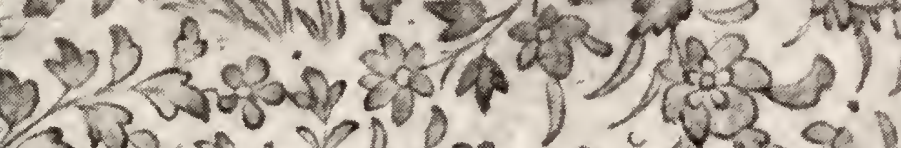

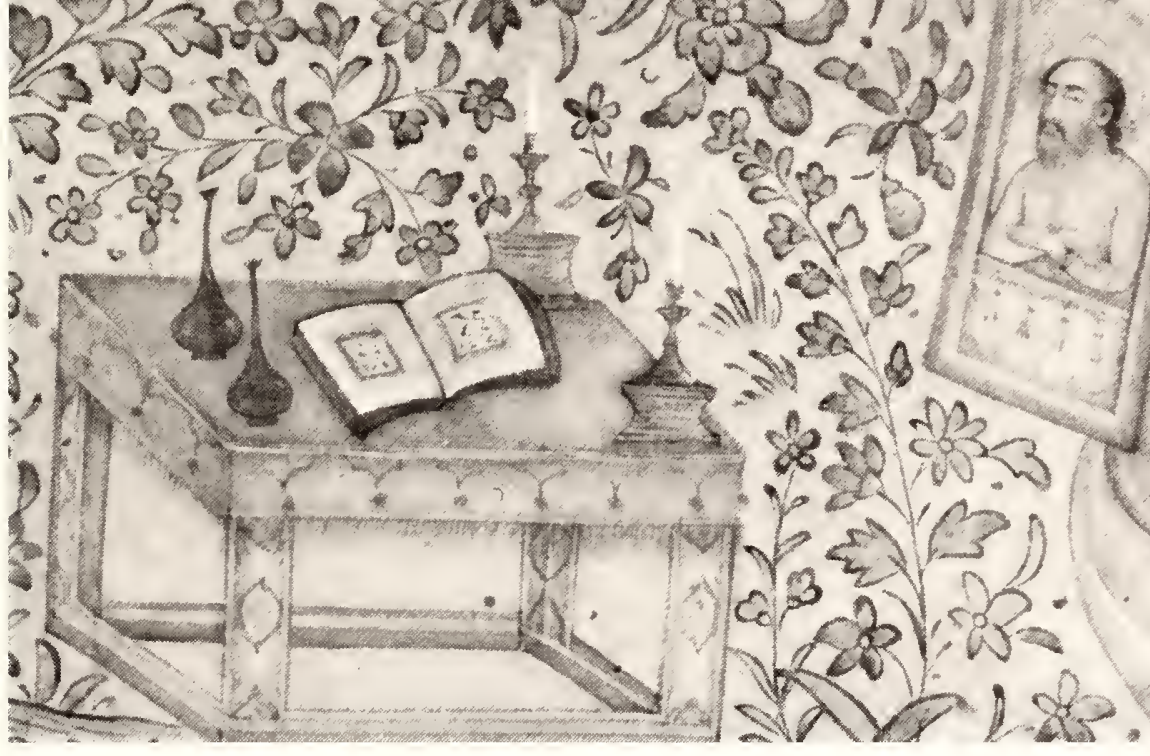

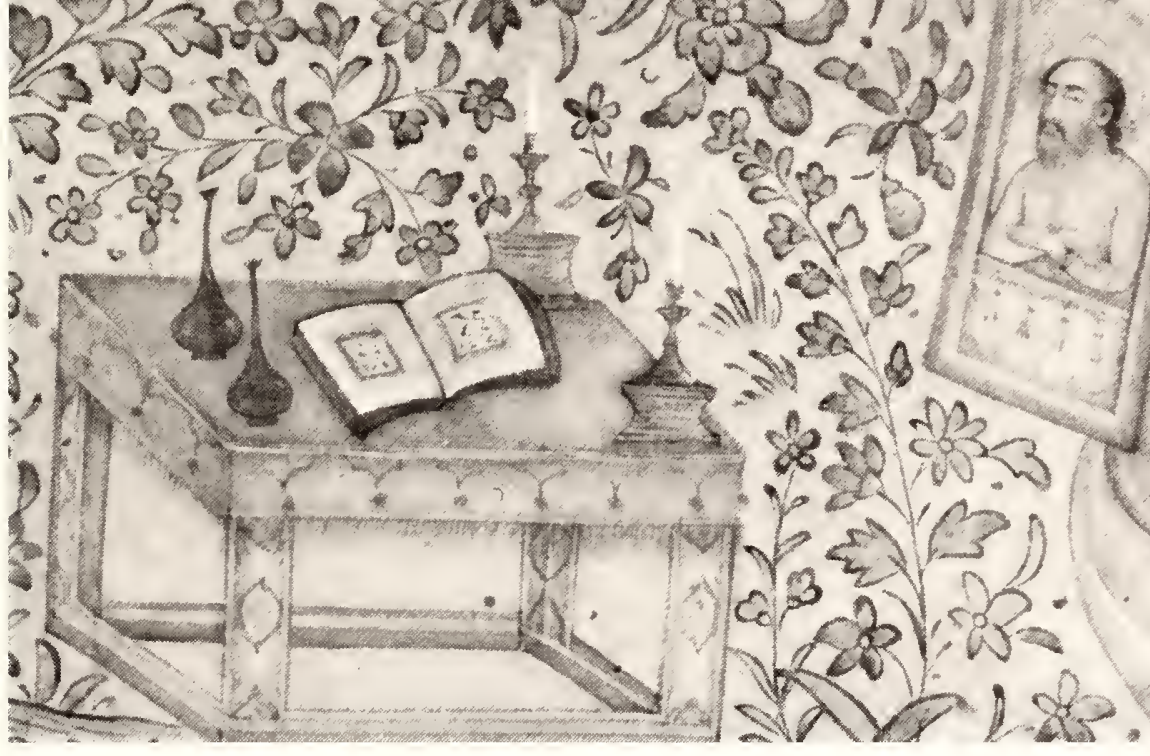

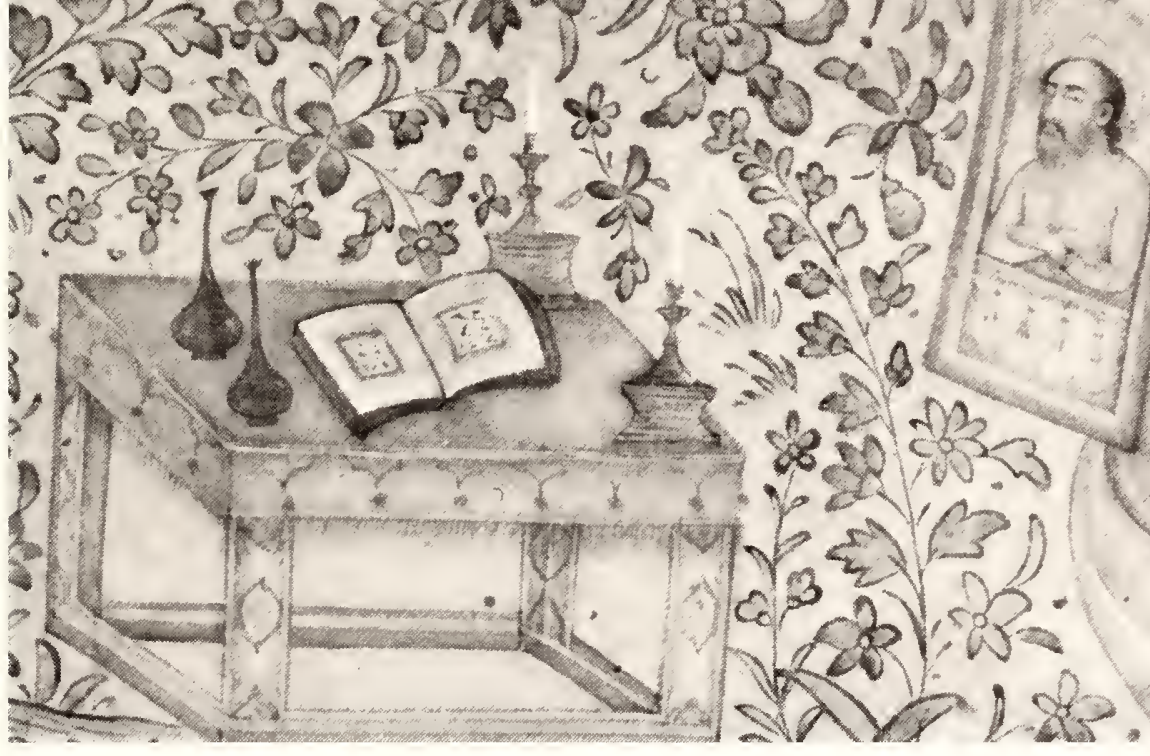

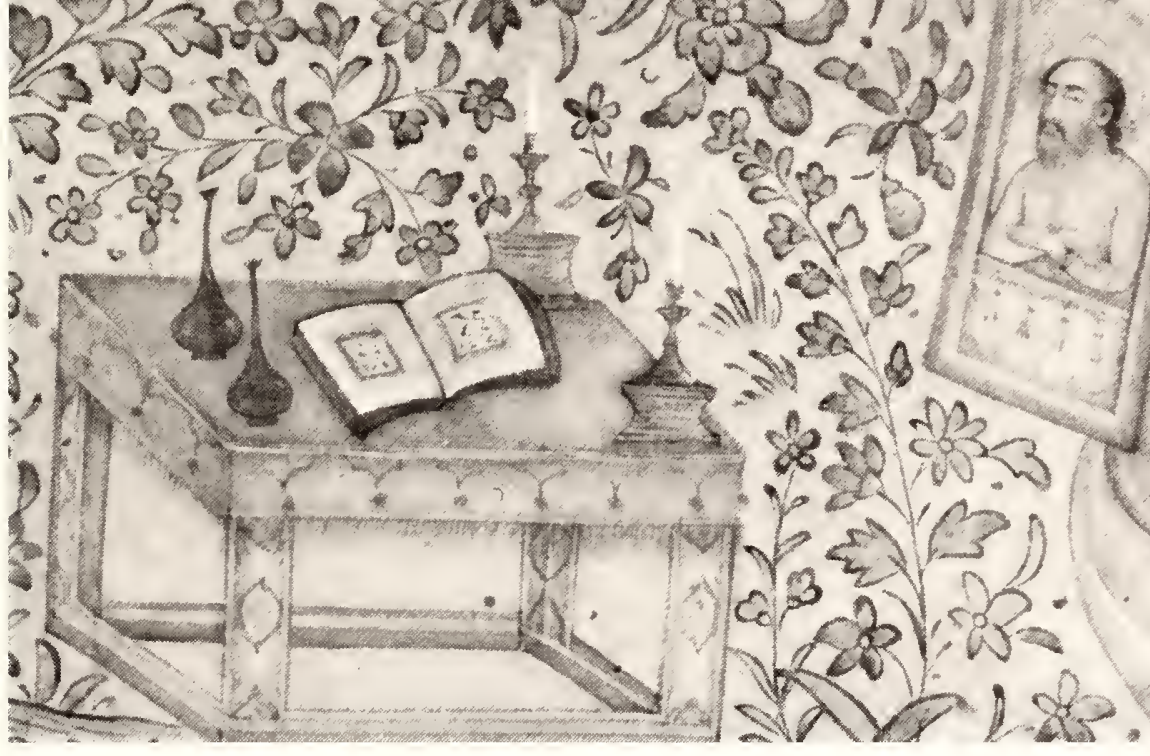
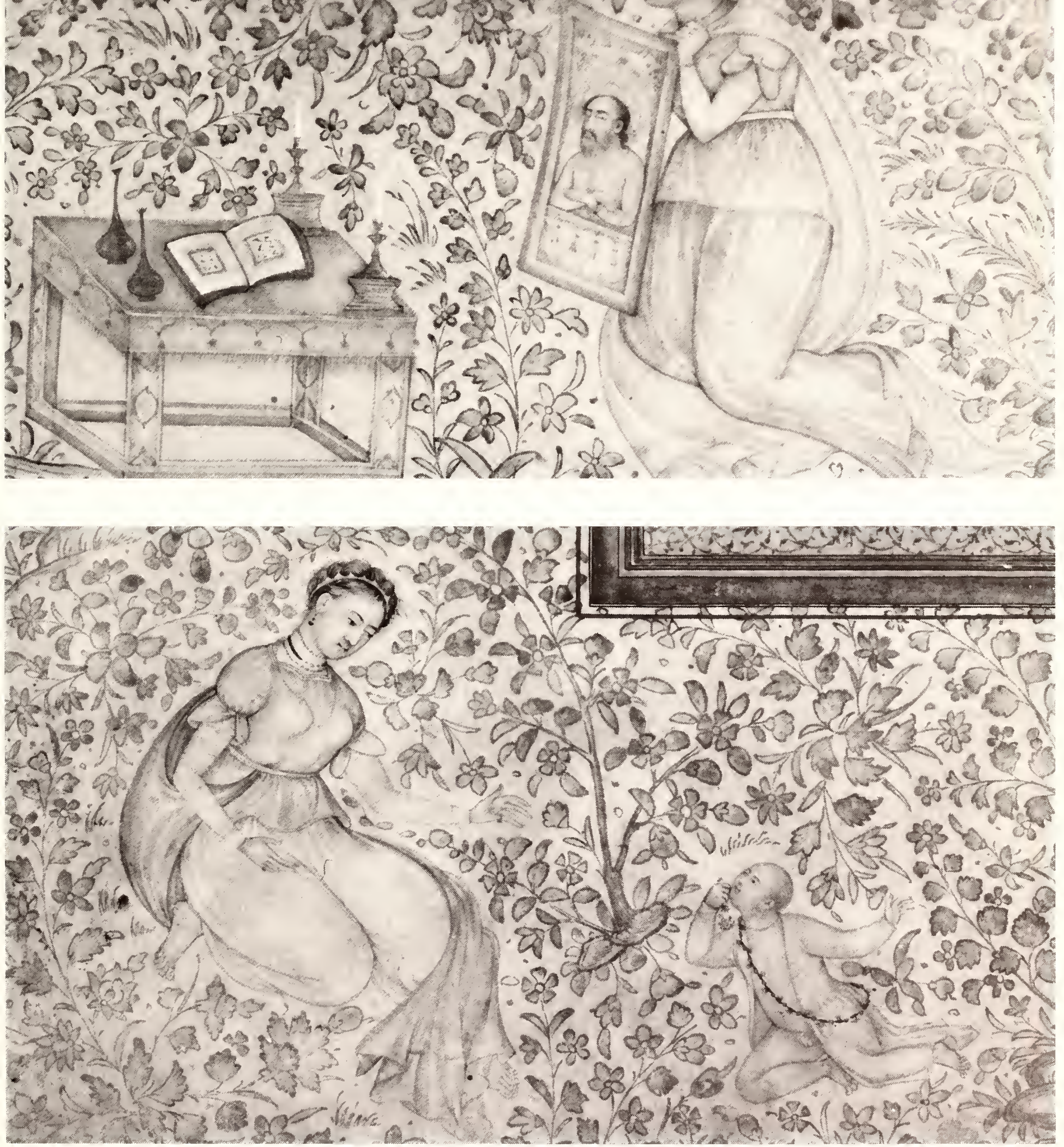
63. Six Artists Preparing Books From the Jabangir Album

India, Mughal school, ca. $160(0-1610$

Btack line and gold on paper; tinted with red, pink, blue, green and white

Page: $42.5 \times 26.6 \mathrm{~cm}$.

(163/4 $\times 10 \frac{1}{2}$ in.)

Text (including borders): $26.8 \mathrm{x}$ $15.8 \mathrm{~cm} .(109 / 16 \times 61 / 4 \mathrm{in}$. 54.116

On the verso of this folio is a painting representing a prince on horseback who is being handed a drink from a youth seated on a tree platform. The recto contains a sample of calligraphy obliquely written in mastalik and signed by Mir Ali, a famous 16th-century calligrapher whose work is frequently included in the Jahangir albums (nos. 64 and 65). Mir Ali was from Herat and worked in his native city until 1528-29 when it was captured by the Uzbeks who took him together with several other artists to their court in Bukhara. Like his namesake from Tabriz (nos. 1-7), the calligrapher excelled in the nastalik script and wrote a great number of samples for atbums until his death in 1558 tit

The marginal drawings represent six artists preparing books, each involved in a different action. The figures are placed in a landscape with the hills, trees and flowers painted in gold against a beige ground. Their garments and equipment are highlighted with polychrome washes which also have golden tones.

The figure on the upper right is a papermaker, energetically polishing a sheet with a heavy burnisher. Opposite him is a bookbinder seated in front of a low table, stamping the cover of a manuscript; the tools of his trade are scattered around the table while several book covers tie on the ground. Below is another artist who files the edges of a bound book which is held by a wooden clamp; a couple of volumes are on the ground whereas another one, presumably finished, is placed on

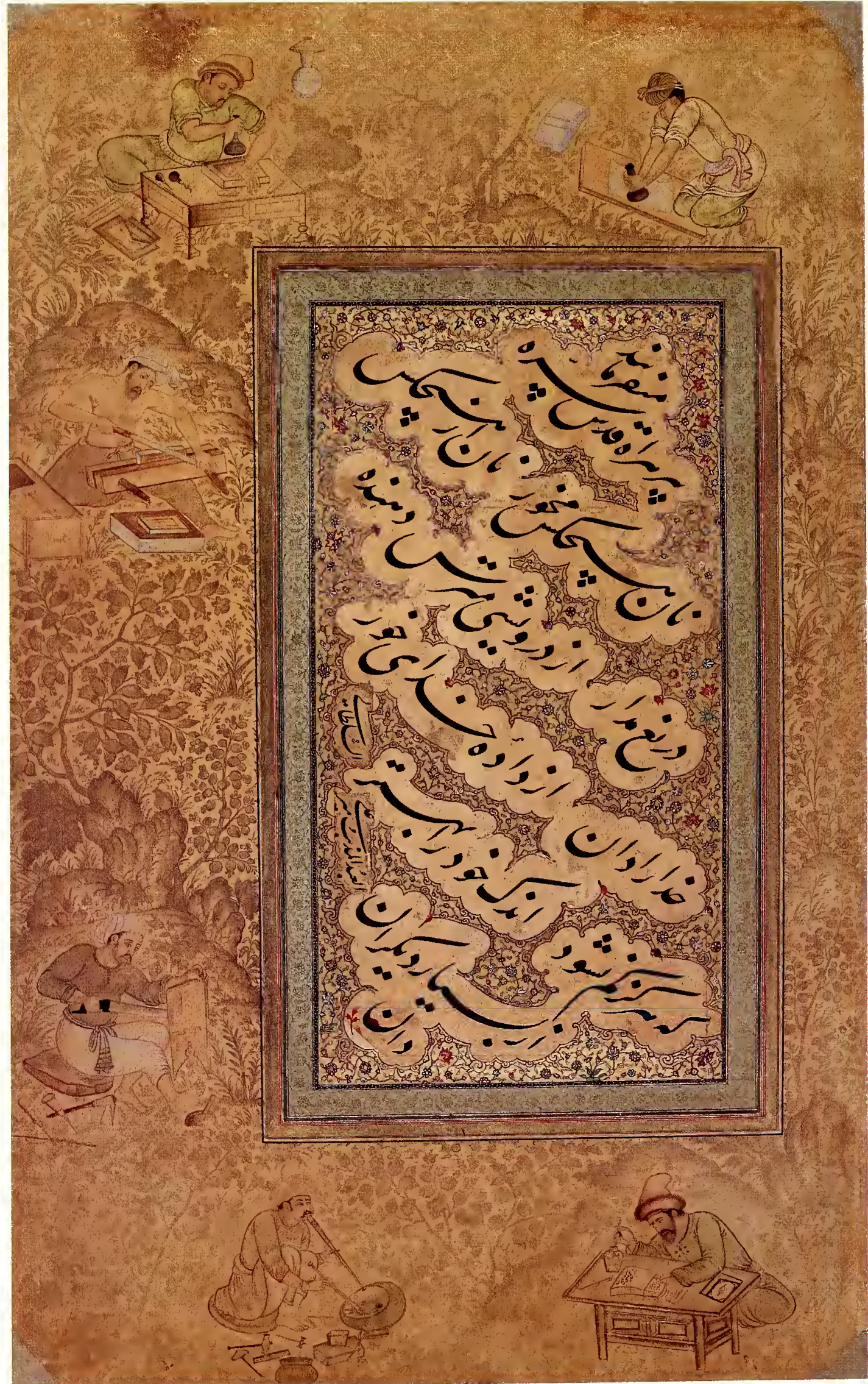




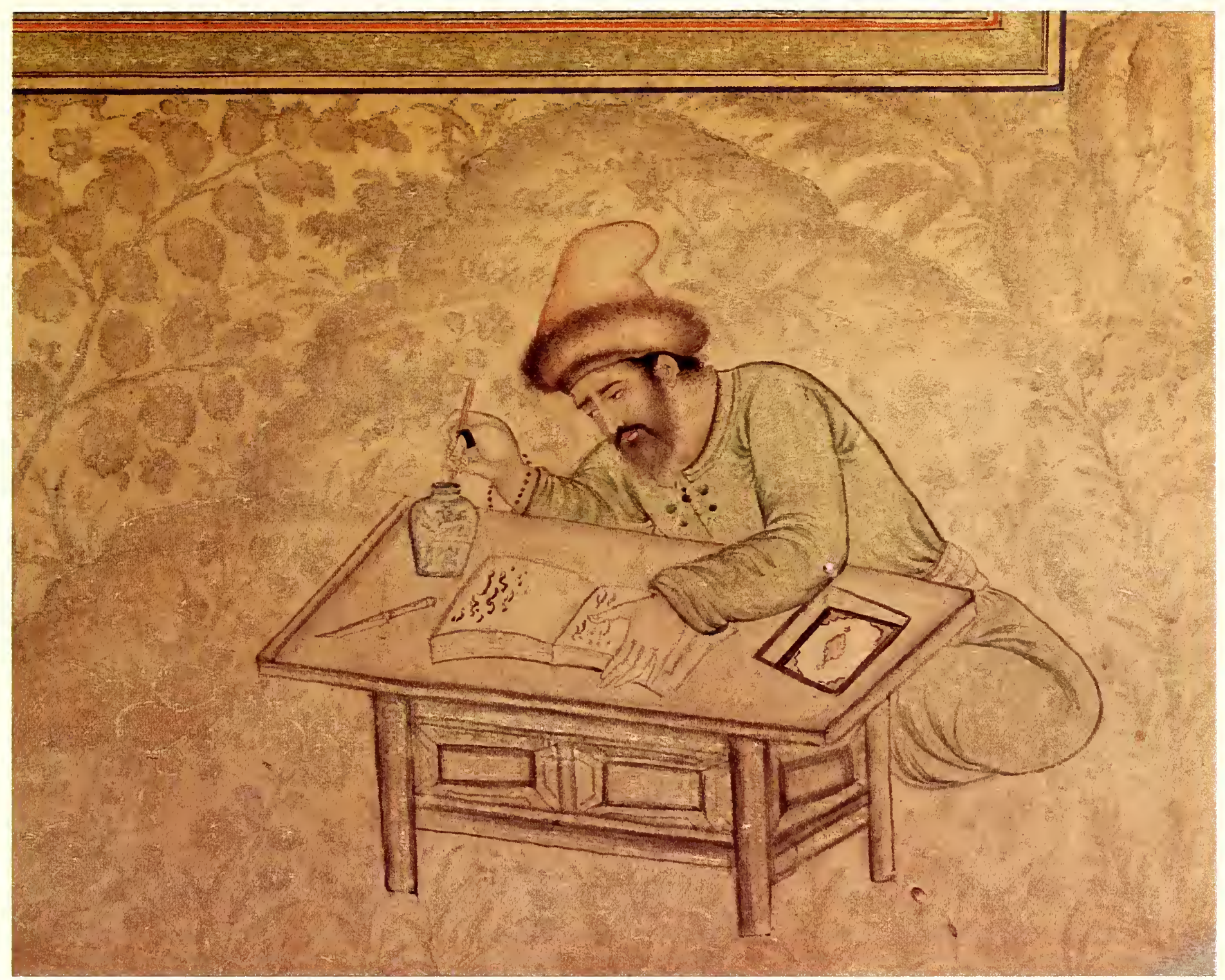

a low chest. The man immediately below is making a wooden bookstand, working with a saw, surrounded by his equipment consisting of various carving tools and blocks. On the lower left, an artist smelts gold, blowing with a long rod the fire lit in an open container; a bar of gold ready to be melted is placed next to him together with several tools and a large golden pot. The last figure represents a calligrapher who is working on a low table; he is writing the text in a bound volume, dipping his brush into a blue-and-white inkwell.
The drawing represents various stages in the production of a book from papermaking to the final step of copying the text. The methods employed by the artists and the specific tools used for different activities are graphically documented, providing an invaluable source for the technology and the arts of the age.

Both the Tehran and Berlin albums contain similar figures in the margins, signed by Aka Riza and Govardhan. ${ }^{61}$ 
64. European Figures and Scenes From the Jahangir Album

India, Mughal school, ca

$1600-1610$

Black line and gold on paper;

tinted with red, green and

yellow

Page: $42.5 \times 26.5 \mathrm{~cm}$.

$10 \%$ in .)

Text (including borders): $26,6 \mathrm{x}$

$15.6 \mathrm{~cm} .(101 / 2 \times 61 / 8 \mathrm{in}$.

56.12

A painting depicting a landscape with chained elephant, attended by its mahout and a servant, appears on the recto of the folio while the verso contains three nastalik panels. The larger panel is a quatrain written by Mir Ali, set against a background adorned with flowers, blossoming trees and birds. The same exquisite decoration appears behind the smaller panels; the longer strip on the left also bears the name of Mir Ali (nos. 63 and 65). Four beautifully drawn birds are placed above the text.

The figure on the top of the margin portrays the God-Father floating over the universe. The panel on the upper right, depicting a female and nude child holding tablets, is identified by its inscription, "Geometria." The Christian saint with sheets of paper who appears below is thought to be St. Anthony. The boat on the lower right represents the Ship of Salvation with the Christ Child. The group on the lower left shows the Virgin holding the Christ Child on her right arm while infant $5 t$. John stands next to her left leg.

The figures are set against a gold landscape with rocks, trees and face a do hind the ship which sails on a golden se

The marginal drawings are characteristic of the period and represent century religious and mythological themes copied from European prints. Two cartouches below the ship on the lower right contain "1580" and "Rome," giving the date and source of the original

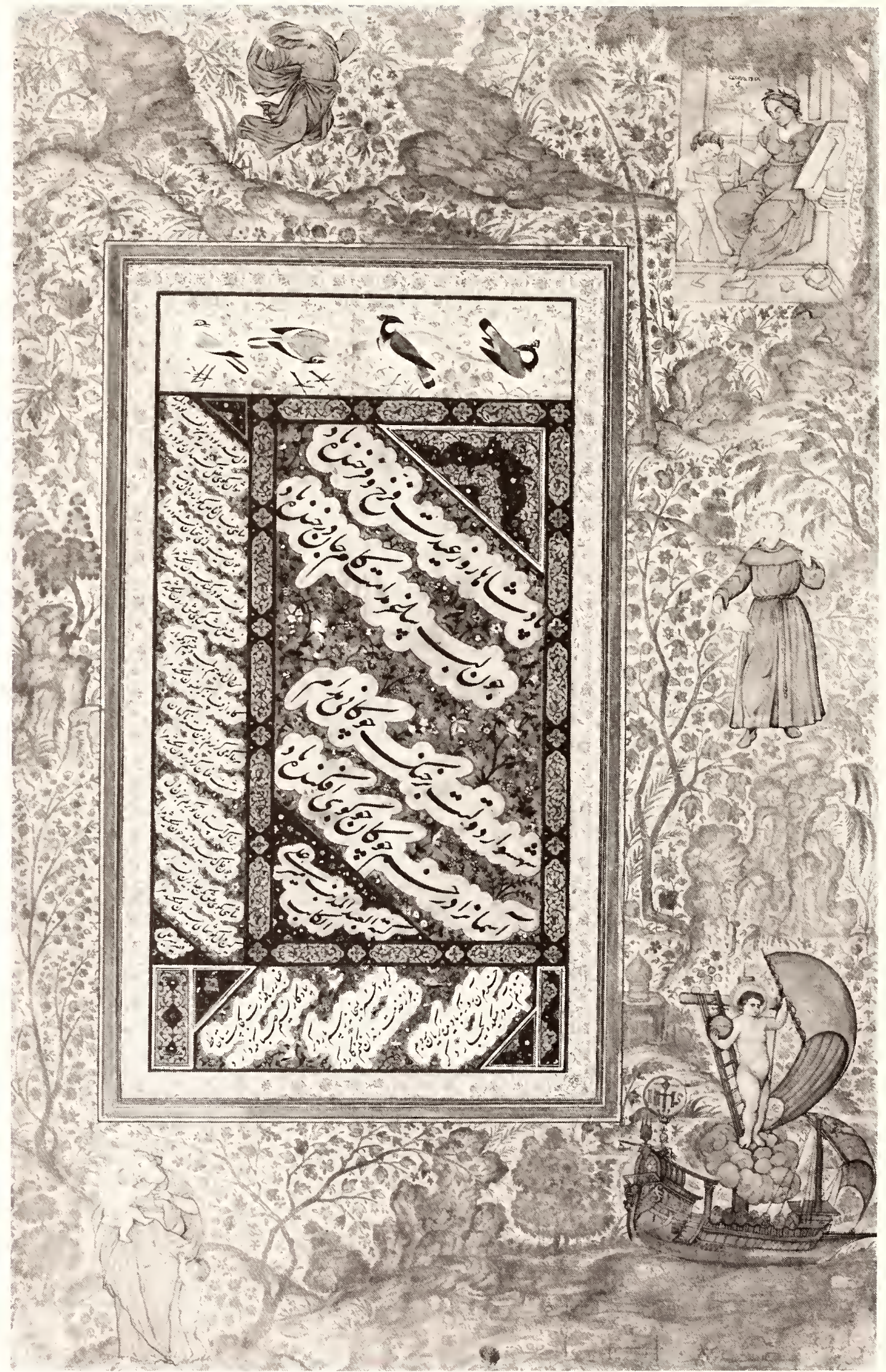



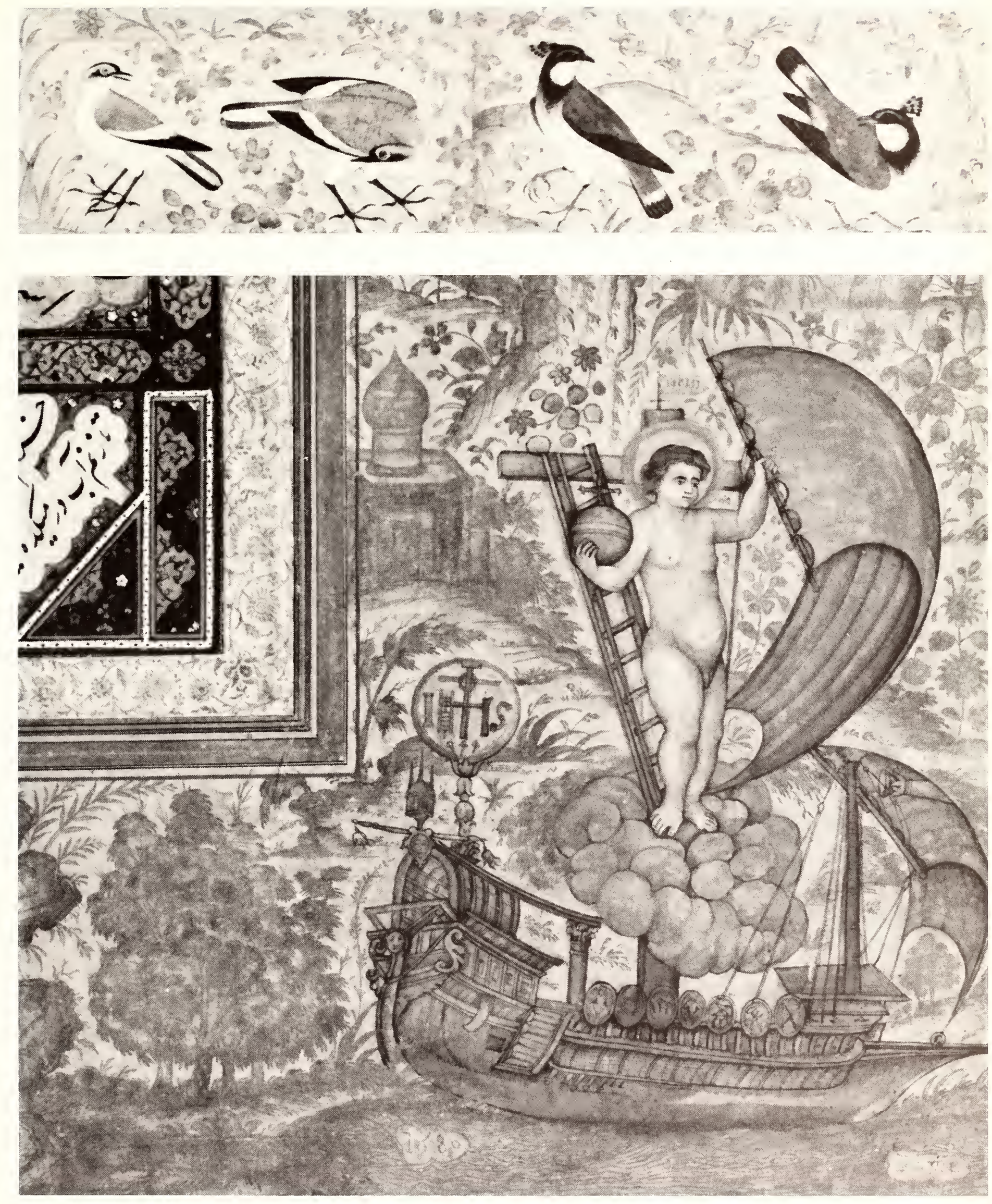
65. Six Men in a Landscape From the Jabangir Album

India, Mughal school, $\mathrm{Ca}$

$1600-1610$

Black line and gold on paper; tinted with red, pink, blue, green and white

Page: $42 \times 26.5 \mathrm{~cm}$

$(161 / 2 \times 101 / 2$ in.)

Text (including borders): $27.5 \mathrm{x}$ $19 \mathrm{~cm} .\left(10^{13 / 16 \times 71 / 2 \mathrm{in} .)}\right.$

63.4

The verso of the album sheet contains a painting representing Jamshid writing on a rock with a notation that gives the date as 1588 and includes the name of the artist, Abd al-Samad Shirin Kalam. Abd al-Samad, invited to the Mughal court by Humayun in 1556 , was put in charge of the imperial painting studios during Akbar's reign and continued working in the capital until the turn of the century.

The marginal decoration of the recto contains considerably more color and represents six figures in a landscape with birds and insects hovering around the trees and flowers. The nastalik texts in the center of the folio are adorned with similar motifs, executed in color. The obliquely written panel is signed by Mir Ali whose works were included in two other folios (nos. 63 and 64)

The figures in the margins appear to be occupied with astrological calculations and represent courtly types. On the upper left is a young prince attired in a translucent white robe, standing on a stool and praying with his arms extended. The older figure behind him repeats the gesture while a half-naked ascetic, sitting on the far left, observes the pair. Below him is a courtly figure, who sits on a chair and reads a book. On the lower portion of the margin an astrologer holds up an astrolabe; an open book, a roll of paper and writing utensils are placed on the sheet spread in front. The astrologer is most likely calculating the horoscope of the figure seated opposite, who is attired in fashionable garments of the court and bears a sword.

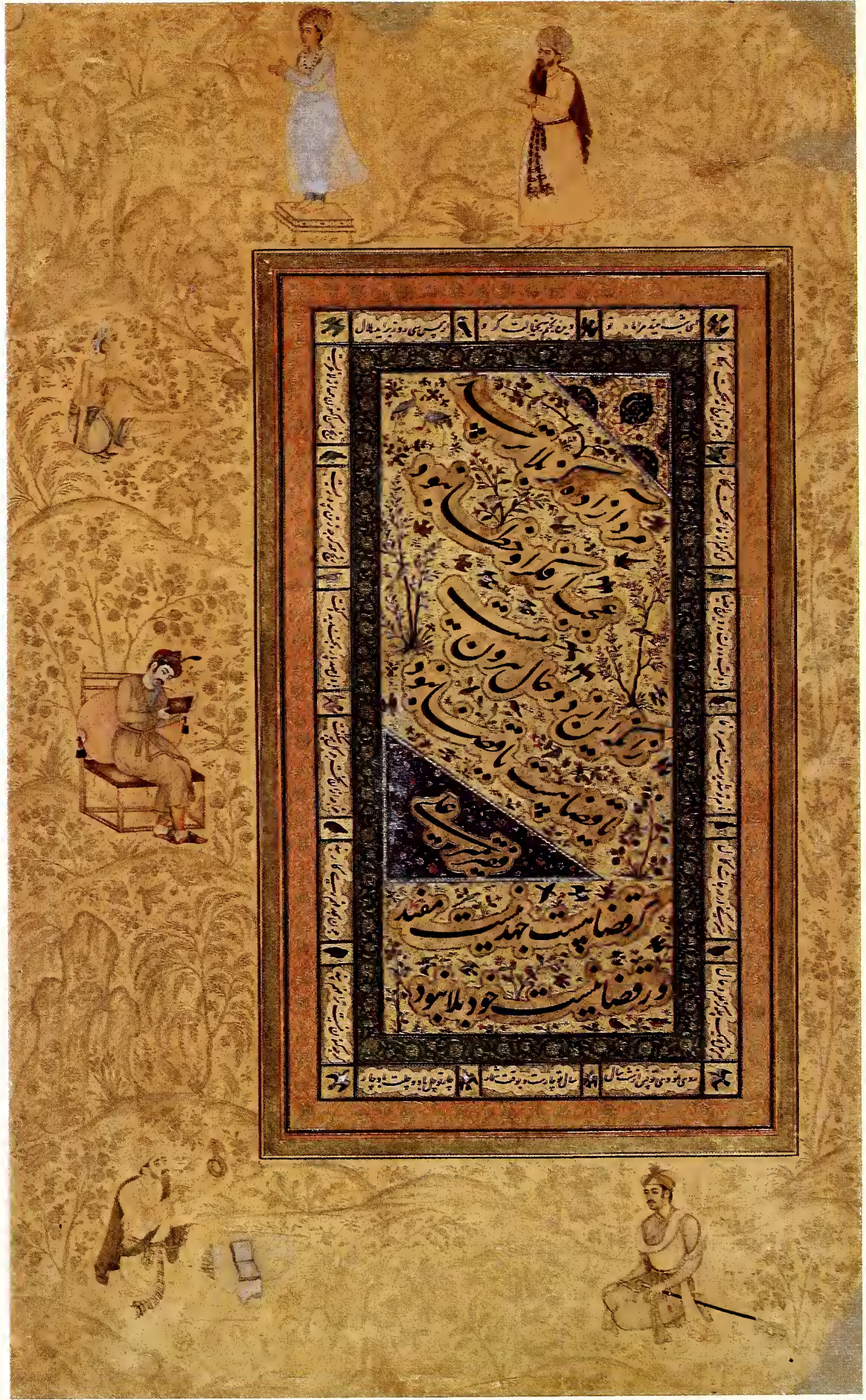




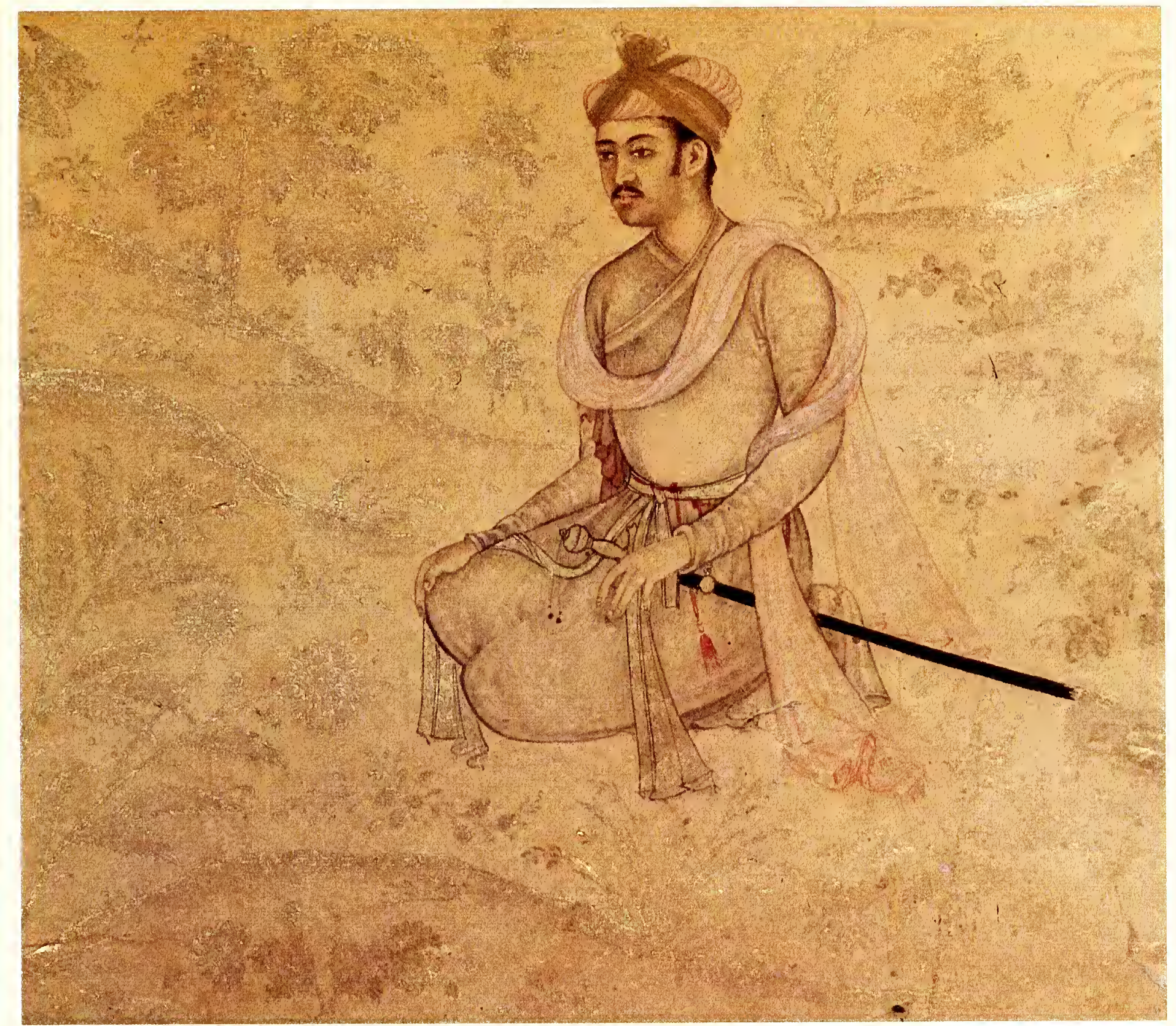

This folio was prepared with extreme care, combining the best talents of Jahangir's court as observed in the delicate execution of the figures and landscape decorating the margins, the beautiful illumination with flowers and birds harmoniously balanced by the fine script. 
66. Pilgrim with an Ascetic

India, Mughal school, early 17th century

Black line on paper; tinted with red, blue and green

Page: $25 \times 15.8 \mathrm{~cm}$

(97/8 $\times 61 / 4$ in.)

Drawing: $10.4 \times 9.3 \mathrm{~cm}$

$\left(4 \frac{1}{6} \times 3 \frac{3}{4}\right.$ in. $)$

29.76

This example depicts a landscape with two figures, one of whom is a half-naked ascetic. The drawing, also mounted on cardboard with a marginal decoration placed around it, was adjusted to fit the opening by the addition of two panels of marbled paper above and below, using several carelessly executed borders to camouflage the seams The marginal decorations, executed in gold, are pasted sideways and depict a pair of roosters and deer in a landscape

The drawing represents a pilgrim holding an open book, discussing its contents with the ascetic who is realistically portrayed as a wiry, emaciated man. Their seemingly contradictory lives which achieve the same spiritual end is symbolized by the two trees in the center with a flowering shrub intertwined around a cypress tree

The landscape and portions of the protagonists' garments are tinted in color while the faces are executed in soft brush strokes.

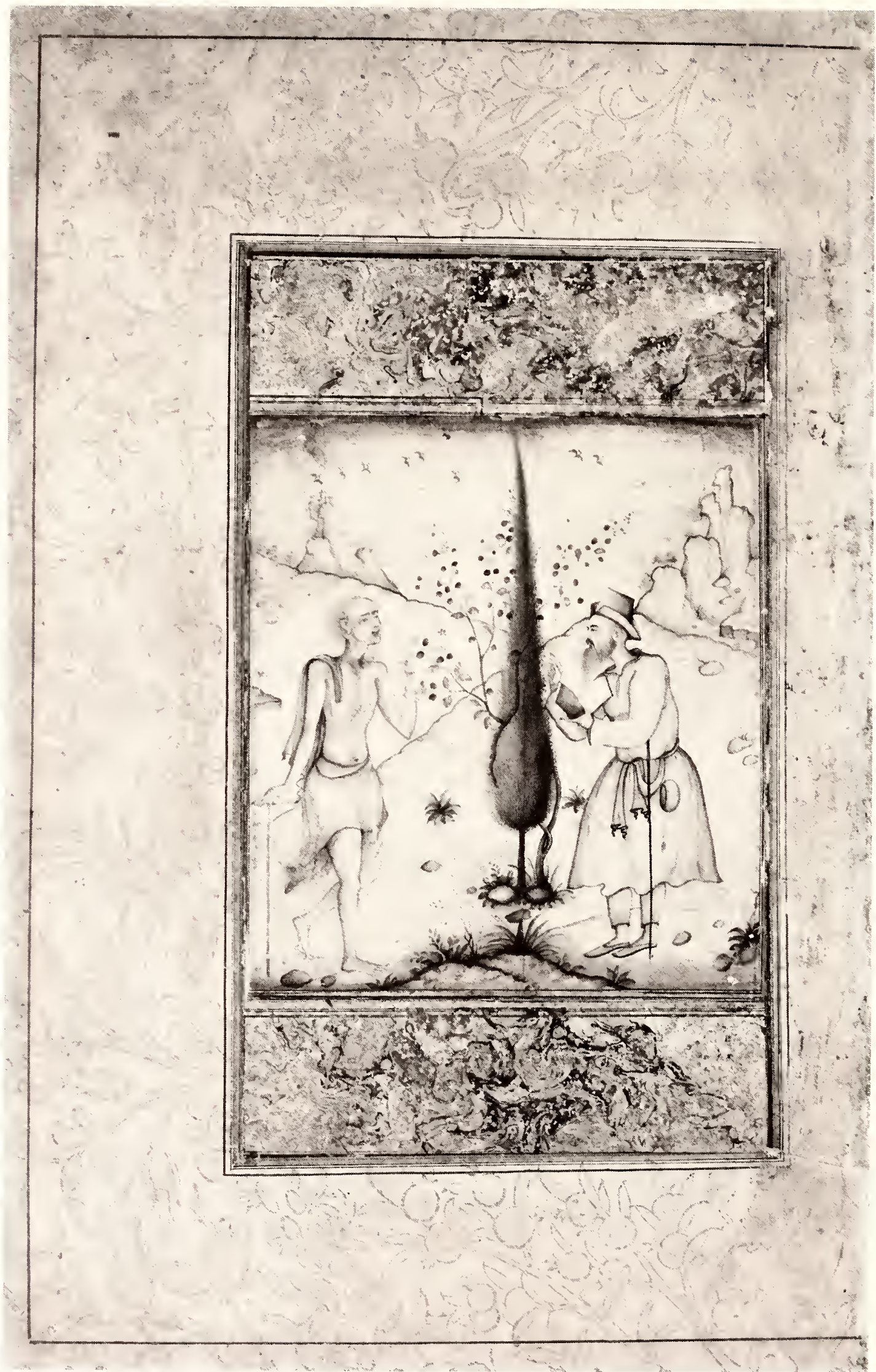


67. Sultan Parviz with an Ascetic India, Mughal school, early 17th century

Black line, gold and silver on paper; tinted with red, pink, green, yellow and white

Page: $30 \times 18.8 \mathrm{~cm}$

$\left(11^{13 / 16 \times 73 / 8}\right.$ in.)

Drawing: $15 \times 8.6 \mathrm{~cm}$.

$(57 / 8 \times 25 / 8$ in.)

29.3

The tinted drawing is pasted on a sheet which depicts a landscape with figures and is backed with cardboard. Strips of gold and silver are carelessly placed around the drawing, attempting to frame the scene and to fit it into the blank area between the marginal decorations

The scene in the margin, executed in gold and silver on a pink

ground, represents a brook which flows around and under the drawing, its banks covered with blossoming trees and clusters of flowers. On the right an ascetic, wearing only a stole and a loincloth, converses with a man holding a book. The sheet is older than the drawing as the latter was adjusted to fit into the allotted space with an extra strip added to the top The marginal decoration is beautifully executed although the oxidation of the silver has somewhat lessened its rich coloring.

According to the inscription, the tinted drawing represents Sultan Parviz who was one of the sons of Jahangir. The young prince is attired in the characteristic garments of the age: he wears a flat turban, a tight bodice and pants and long skirt tied with flowing embroidered sash; a string of pearls and a jeweled necklace hang around his neck while a dagger is tucked into his belt. He converses with a holy man who holds a rosary in one hand, a pouch and a stick in the other; the ascetic is naked except for his loincloth and long hair which falls in streaming locks to his waist. The figures are standing by a stream, below a large plane tree partially cut by the frame. Soft washes appear in the garments and landscape with touches of gold accentuating the jewelry of the prince.

This example was executed during the reign of Jahangir and it appears that a suitable margin was sought to enhance the drawing.

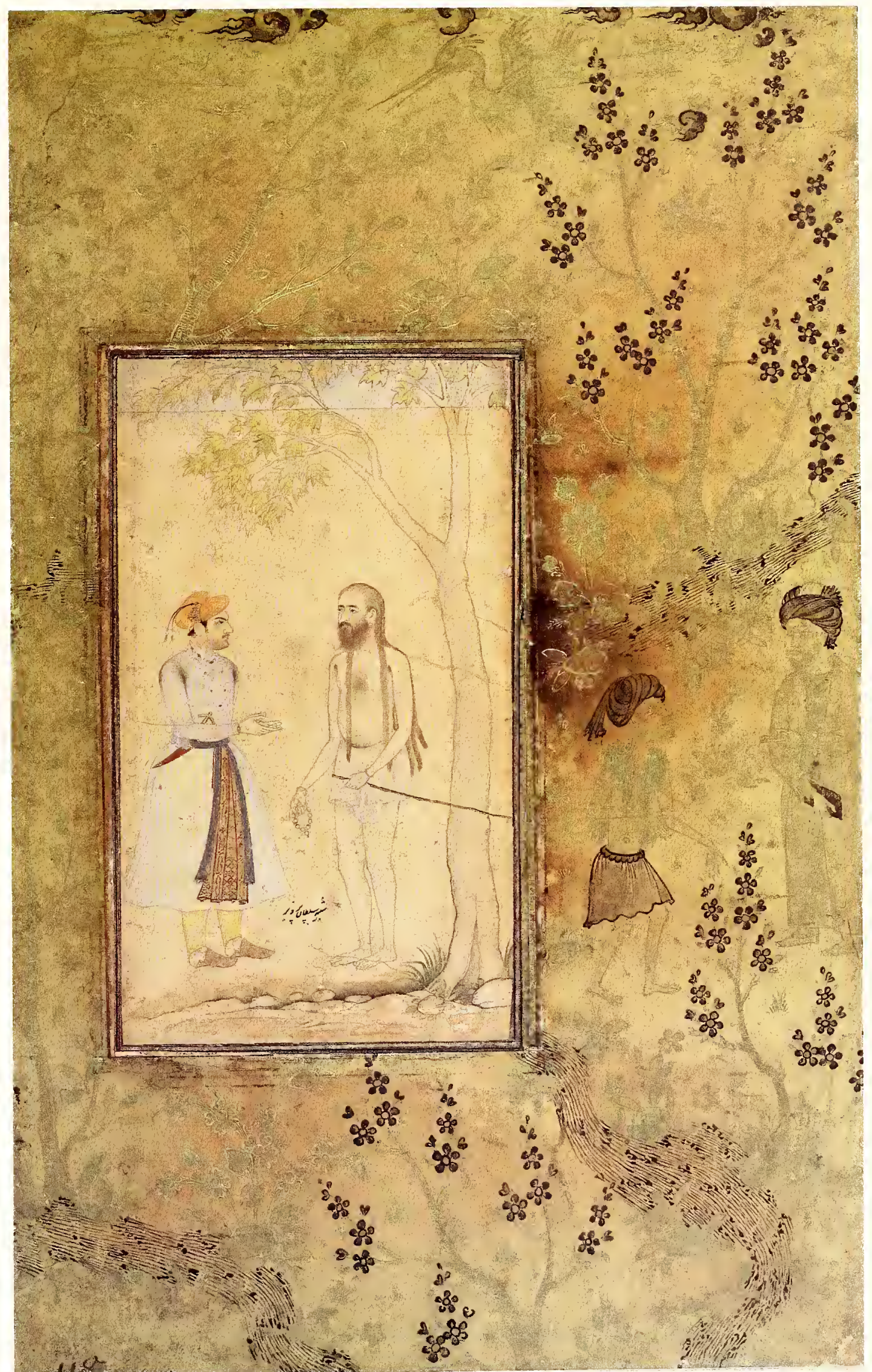


68. Youth with a Book Attributed to Nadir al-Zaman India, Mughal school, early 17th century

Black tine and gold on paper; tinted with red, pink, blue and yellow

Page: $15 \times 10 \mathrm{~cm}$ $\left(57 / 8 \times 3^{15 / 16 \text { in. })}\right.$

Drawing: $12.5 \times 7.3 \mathrm{~cm}$. $(47 / 8 \times 27 / 8$ in. $)$

07.161

The drawing presents a sensitive portrait of a young man engrossed in his book; it is mounted on cardboard and framed with a border of gold leaves on a scrolling blue vine. The inscription, added almost a century and a half later, states that this is the work of Nadir al-Zaman, the court painter of Emperor Jahangir, and gives the year 1768 . The attribution could very well be valid as the fine execution of tine and elaborate working of the details can be found in the other works of Abu'l-Hasan, who was given the name Nadir al-Zaman by his patron, Jahangir

The portrait is possibly one of the earliest works of the artist who was trained by his father, Aka Riza, also employed in Jahangir's court studio. The artistic convention of depicting courtly figures with one leg crossed over the other and the hand holding a handkerchief resting on the knee was established in the Safavid court and continued to be employed by the Mughal artists. The high stool, one shoe lying on the ground and the slightly bent head are conventions atso found in Safavid paintings (no. 23).

Gold is used in the metallic portions of the garments, such as the embroidery on the turban, belt and handkerchief as wetl as in the stamped cover of the book and in the scabbard of the sword. Red is employed to accentuate parts of the outfit and to suggest the precious gems on the scabbard. Faint washes of pink, blue and yellow appear on the turban, undershirt and book, providing a soft and delicate coloring in keeping with the youthfulness of the subject.

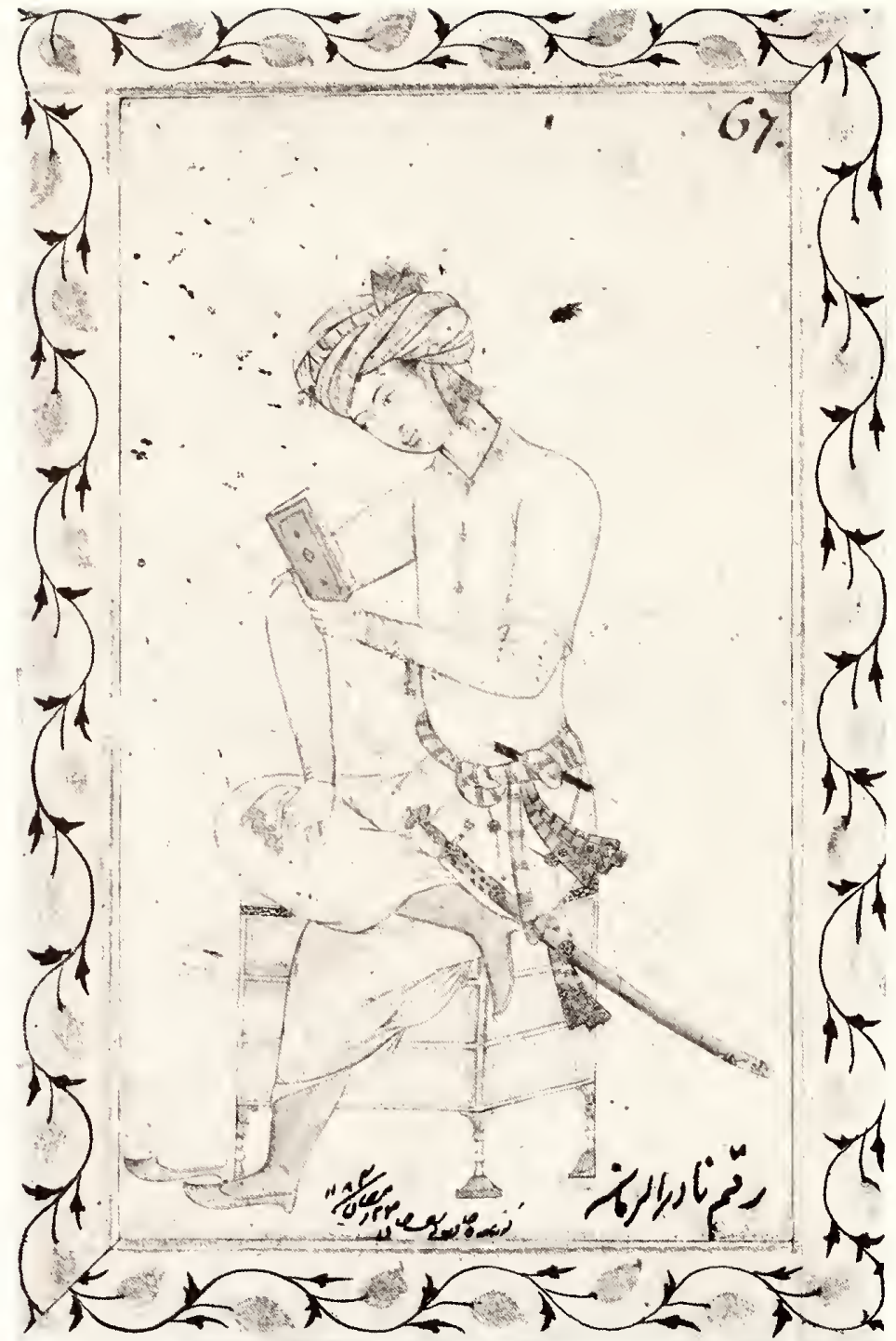


69. Landscape with Animals India, Mughal school, early 17th century

Black line on paper

$25.7 \times 15.4 \mathrm{~cm} .(101 / 8 \times 61 / 16 \mathrm{in}$. 07.618

This example-badly damaged, stained and repaired-was possibly a sample page for animal and plant studies. The animals are scattered around the sheet which represents several vignettes intermingled with fine drawings of flowering plants. In the lower portion are a pair of cranes, a goat trying to feed on the leaves of a tree on which a peacock is perched and a doe attending her young. Above are birds resting on a fruit tree, flowers, other birds and a leopard stalking a pair of mountain goats. On the top of the folio is a lion killing a stag while the mate runs away.

These studies were later incorporated into manuscripts, used either in the paintings, marginal decorations or on lacquer bookbindings. They also served as models for carpets, textiles and other arts which relied on the designs determined by the court artists.

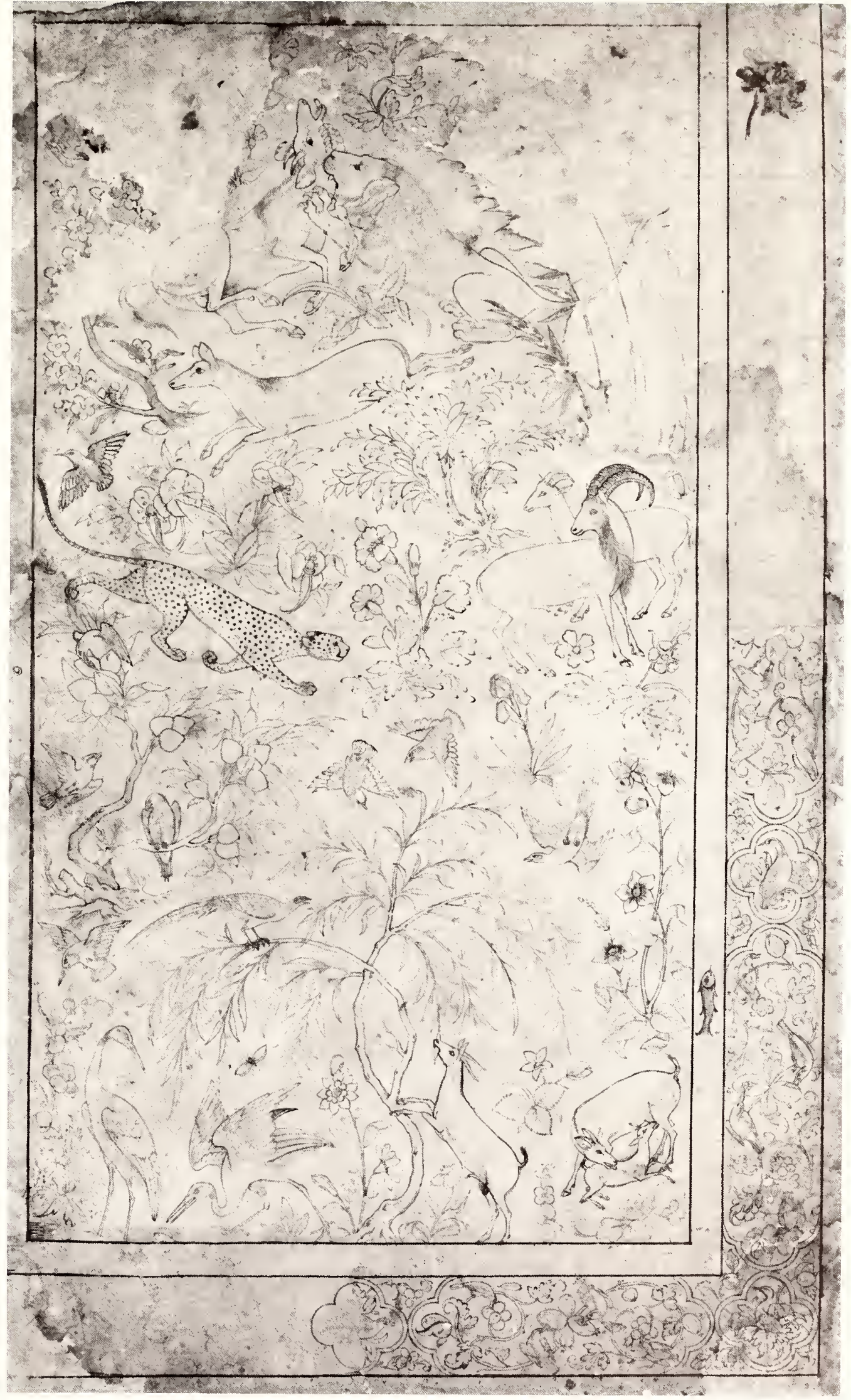


70. Animal Kingdom

India, Mughal school, early 17th century

Black line on paper; tinted with pink, blue, green and yellow

Page: $34.1 \times 21.9 \mathrm{~cm}$.

$(133 / 8 \times 85 / 8$ in.)

Drawing: $23.4 \times 11.8 \mathrm{~cm}$

$\left(9^{3 / 16} \times 45 / 8\right.$ in.)

45.29

This exquisite drawing represents the peaceable animal kingdom with a profusion of creatures skillfully blended into the composition, each depicted in its most characteristic pose. Mughal artists excelled in studies of animats and, with the exception of portraiture, this genre truly represents their tcute observation and refined talents. There are close to 100 birds and beasts depicted in this small drawing, and yet each animal appears as an individual study.

The drawing is mounted on heavy paper; it has several gold, black and blue lines enclosing a band of gold floral designs on a pink ground, cut into strips to form a border. The nurginal decoration, depicting cranes and ducks in a landscape, is executed in black and gold lines on cream paper, matching the theme of the central drawing.

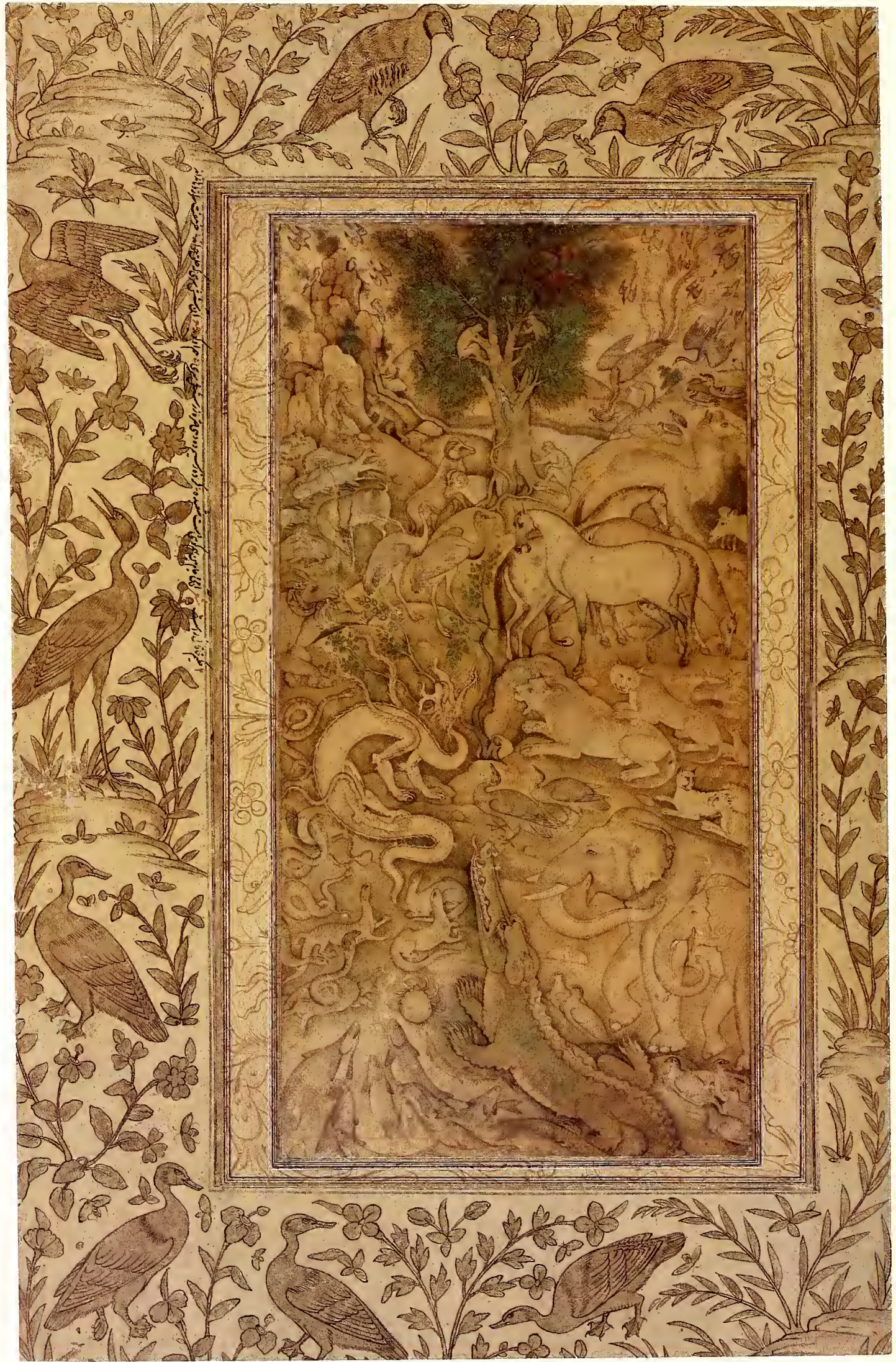




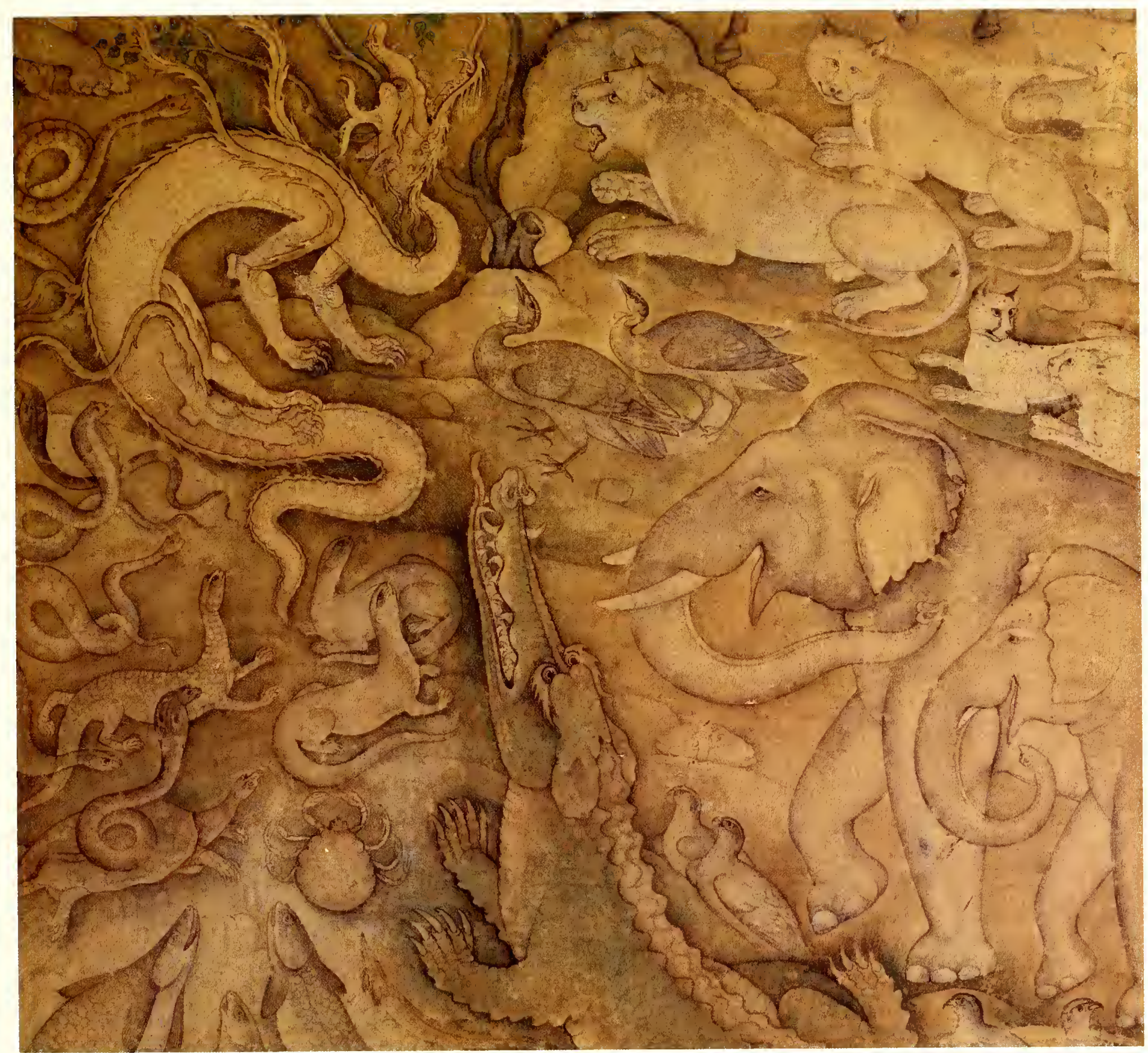

The drawing, tinted in the palest tones, represents the animals as they appear in nature with the creatures of the sky on the top, the inhabitants of land in the center and those who dwell in the seas at the bottom. The animals are shown within their natural habitat with the fish, crocodile, crabs and seals in the water; the reptiles, snakes and a fantastic dragon appear on the shore. The land animals include elephants, tigers, lions, pheasants, foxes

horses, rhinoceroses, camels, deer, goats, sheep, monkeys, bears and cats which gradually lead the eye up the folio, toward the tree in the background. ${ }^{62}$ Diverse birds perch on the tree and rocks or fly into the scene; included among them are ducks, sparrows and a superb phoenix. The artist has combined both domestic and wild creatures, as well as real and imaginary creatures, in a single scene.
This drawing, similar to the examples discussed previously (nos. 66-69), does not belong to the famous imperial collections of Jahangir. However, it reveals the high technical and aesthetic developments of the painters whose works were compiled into less sumptuous but equally exciting albums. 
71. Hunting Scene

India, Mughal school, mid-17th century

Black line, gold and silver on paper; tinted with red and green

Page: $25.7 \times 18 \mathrm{~cm}$ (101/8 $\times 71 / 16$ in.)

Drawing: $16.4 \times 14.3 \mathrm{~cm}$ $(67 / 16 \times 5 \%$ in $)$

07.204

The drawing, which includes its original gold frame, is mounted on cardboard with additional borders added at a later date. The silver applied to the background has oxidized, leaving unattractive dark stains; the portion of water in the foreground was cut out at a later period and replaced by a silver strip, which has also oxidized.

The scene depicts a princely hunt with a young rider shooting arrows at a powerful lion which reels back from the impact. Foxes and hares, frightened by the attack, scamper in either direction; the attendant of the hunter, his turban unwound in the excitement, tries to run out of the way.

\section{A palatial structure appears}

amidst the mountains and trees in the background with two workers strolling toward it. The serenity of the setting, accentuated by a pair of foxes peacefully resting on the rocks, contrasts with the violent drama of the hunt unfolding in the foreground.

An impression of depth is created by the progression of planes and the diminishing size of elements, employing perspective in a most successful manner. Faint washes of red and green are used in the landscape while gold highlights the weapons of the hunter and the trappings of his mount

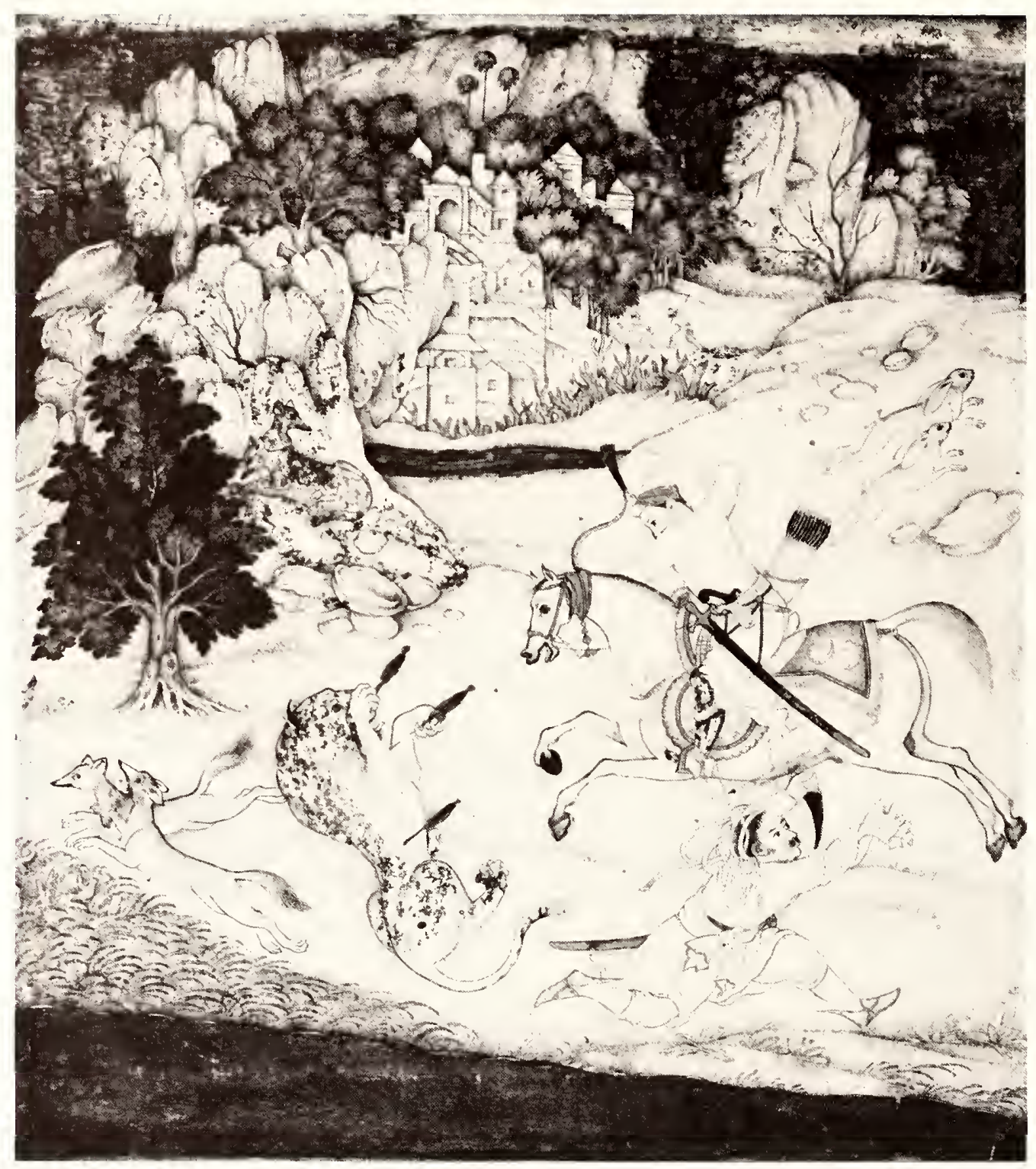


72. Woman Carrying a Basket India, Mughal school, early 18th century

Black line and gold on paper; tinted with red

Page: $37 \times 23.3 \mathrm{~cm}$.

(145/8 $\times 91 / 8$ in.)

Drawing: $13.2 \times 23.3 \mathrm{~cm}$ $\left(5^{3 / 16} \times 2 \frac{7}{16}\right.$ in $)$

07.211

This example represents the provincial Mughal style which appeared after the empire began to lose its authority and could not support the artists, forcing them to seek employment in the provinces. It depicts a young woman carrying a large basket on her head and attired in traditional Mughal garments with a long flowing scarf, short-sleeved bodice and long skirt. Gold accentuates the brocaded portions of her outfit (such as the edges of the scarf and bodice and the horizontal bands in the skirt) and represents her jewelry (the armlets, bracelets and necklace) as well as her gilded shoes. Touches of red appear in the skirt and shoes and highlight the inlaid gems of her jewelry

The drawing has been mounted on a blank sheet with green and gold marbled paper pasted around it. The marbled paper has been sprayed with gold which has spilled onto the drawing

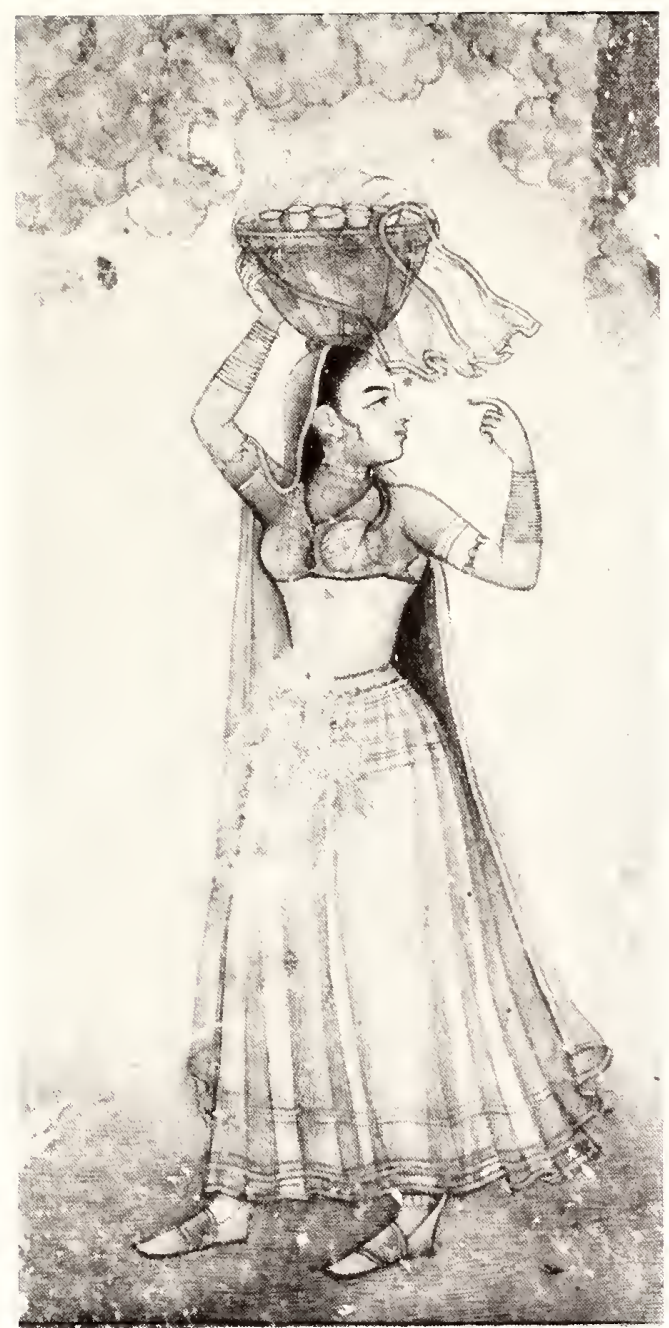


73. Two Women with Attendants India, Mughal school, mid-18th century

Black line, gold and silver on paper; tinted with red, blue, green and white

Page: $40.6 \times 29.3 \mathrm{~cm}$ $(16 \times 11 \%$ in. $)$

Drawing: $23.2 \times 17.8 \mathrm{~cm}$ $(91 / 8 \times 7$ in.)

07.213

The drawing portrays two young ladies seated on a terrace overlooking a body of water beyond which is a strip of land with a large complex. The ladies are attended by two servants who hold peacock-tail fans and are entertained by a quartet of musicians and singers who clap their hands Joining their group are three other women and an attendant who is preparing potent and aromatic concoctions from the contents of bottles and jars spread in front of her.

The drawing, pasted on blink paper, is enclosed by a goldspeckled red sheet and has a blue border decorated with gold floral motifs. The landscape elements are fully colored with green trees filling the background; the pond, barely visible behind the trees, was originally painted silver and now is oxidized. Certain features, such as the two fountains-one on the terrace where the ladies sit and the other behind them-are unfinished with only the outlines of the streans of water sketched in.

The two ladies sit on a carpet, leaning against large cushions: they are smoking water pipes while discussing the contents of a book. Placed on the carpet are other volumes; between the figures is a group of cups and bowls on a mat which is barely sketched

The setting most likely depicts one of the provincial Mughal courts with a large fortified palace and its suburbs represented on the shore beyond the water.

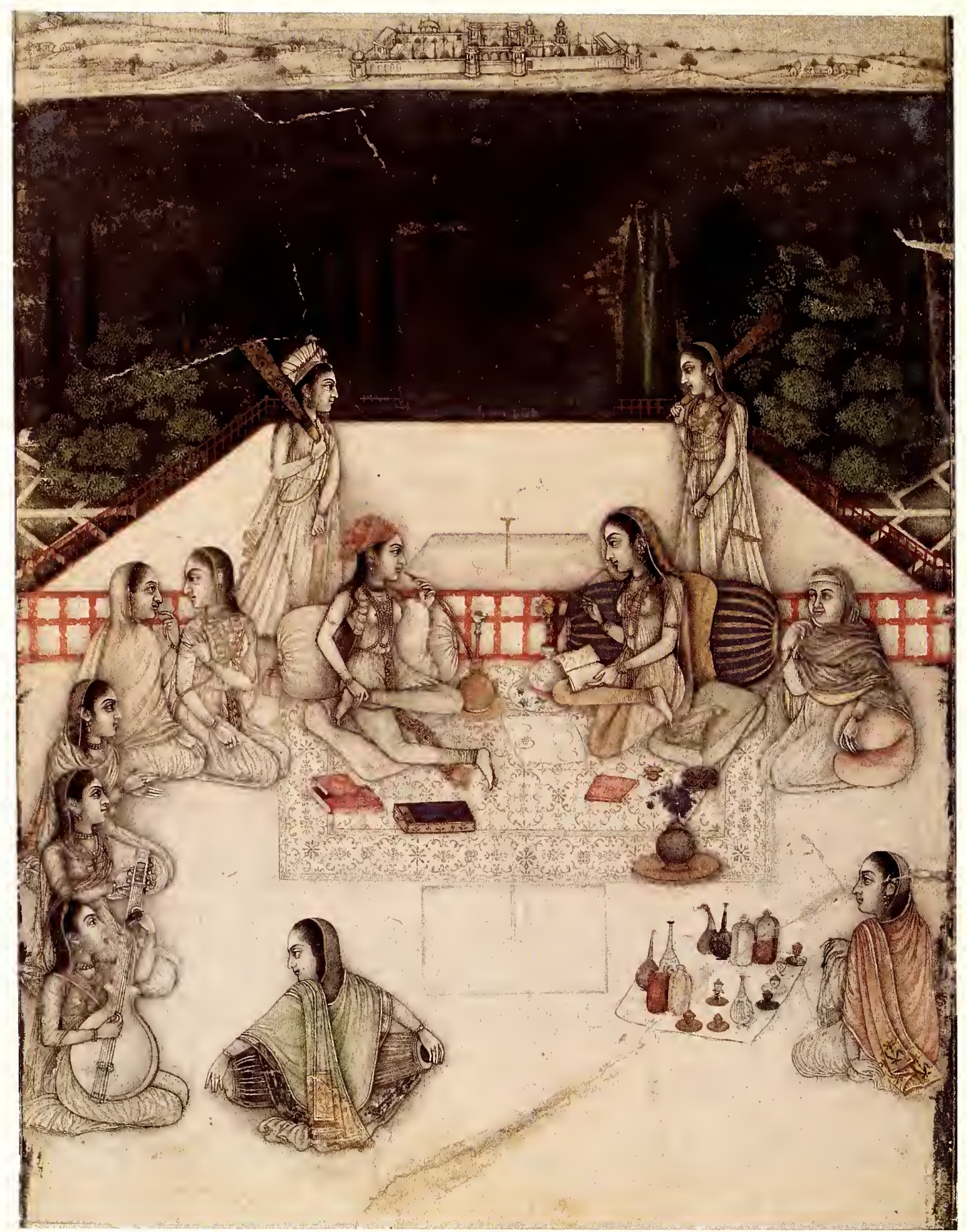




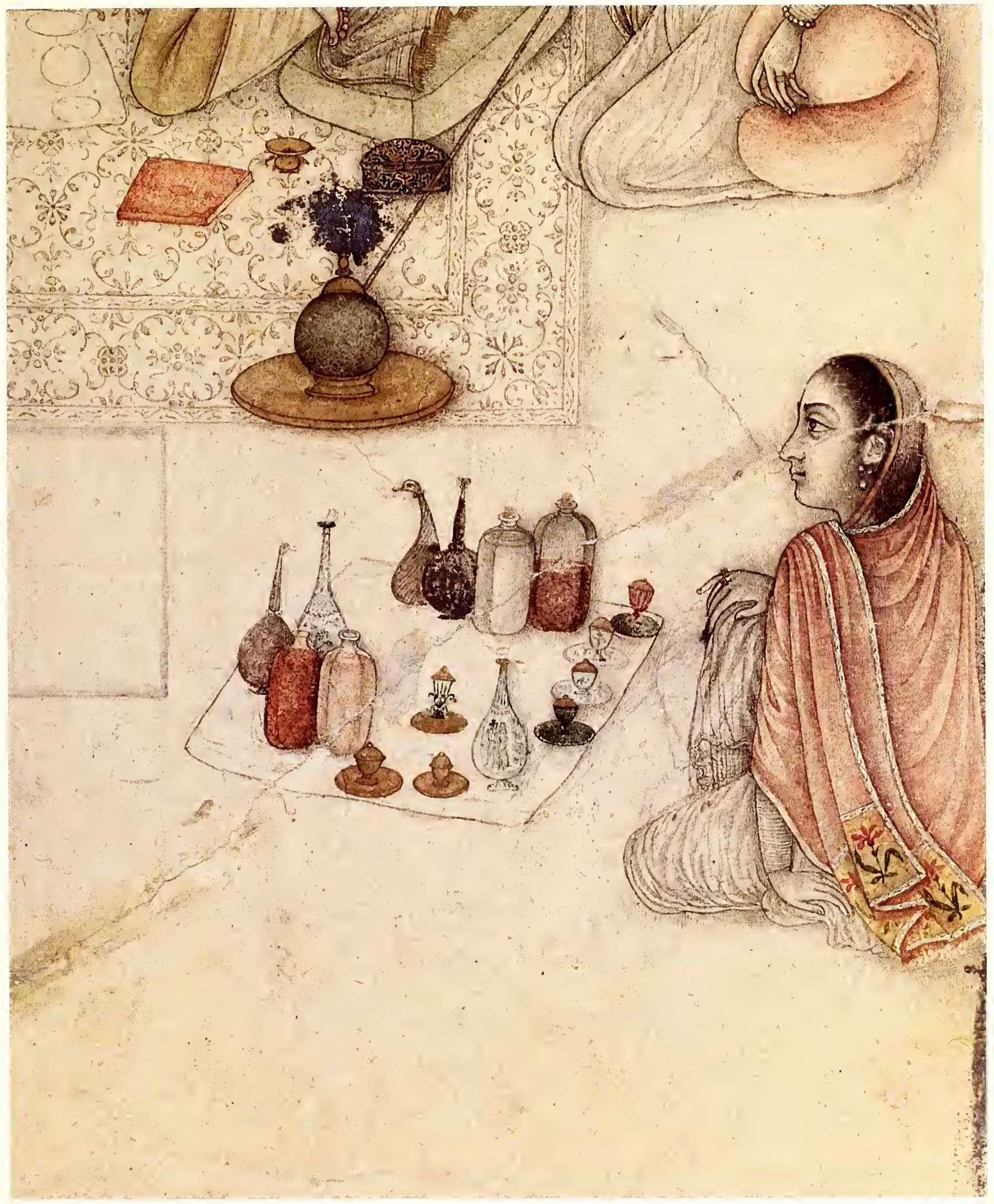


74. Woman with Attendants India, Mughal school, early 18th century

Black line and gold on paper; tinted with red and white

Page: $21.5 \times 14.9 \mathrm{~cm}$.

$(87 / 16 \times 57 / 8$ in. $)$

Drawing: $15.5 \times 9.2 \mathrm{~cm}$

$(61 / 8 \times 35 / 8$ in. $)$

07.607

This drawing depicts a lady seated in the courtyard of a palace, accompanied by five attendants. It is mounted on an album sheet with a 14-line text on the back; the margins around the drawing are painted blue and speckled with gold.

A group of three women appears in the foreground; one reclines against a cushion, another listens to music while the third plays a tambourine. Above them is the main personage, flanked by two attendants, one of whom offers her a drink in a small cup. Longnecked bottles, bowls of fruit, covered boxes and trays with small footed bowts containing delicacies are scattered around the courtyard. A domed pavilion with carved panels depicting bowls and bottles rises in the background with a group of trees seen above the walls of the enclosure.

Gold is used to accentuate the details of the garments and jewelry; it is also applied to the metal vessels. Red appears on the hands and feet of the women, suggesting that they were painted with henna; white is used to represent the pearl jewelry. Two of the women, on the upper left and lower right, have lighter complexions, their skins painted in soft washes of white.

The theme of idle women amusing themselves within the confines of their palaces seems to have been quite popular in the provincial courts, attempting to recreate the luxurious environment of the Mughal capital.

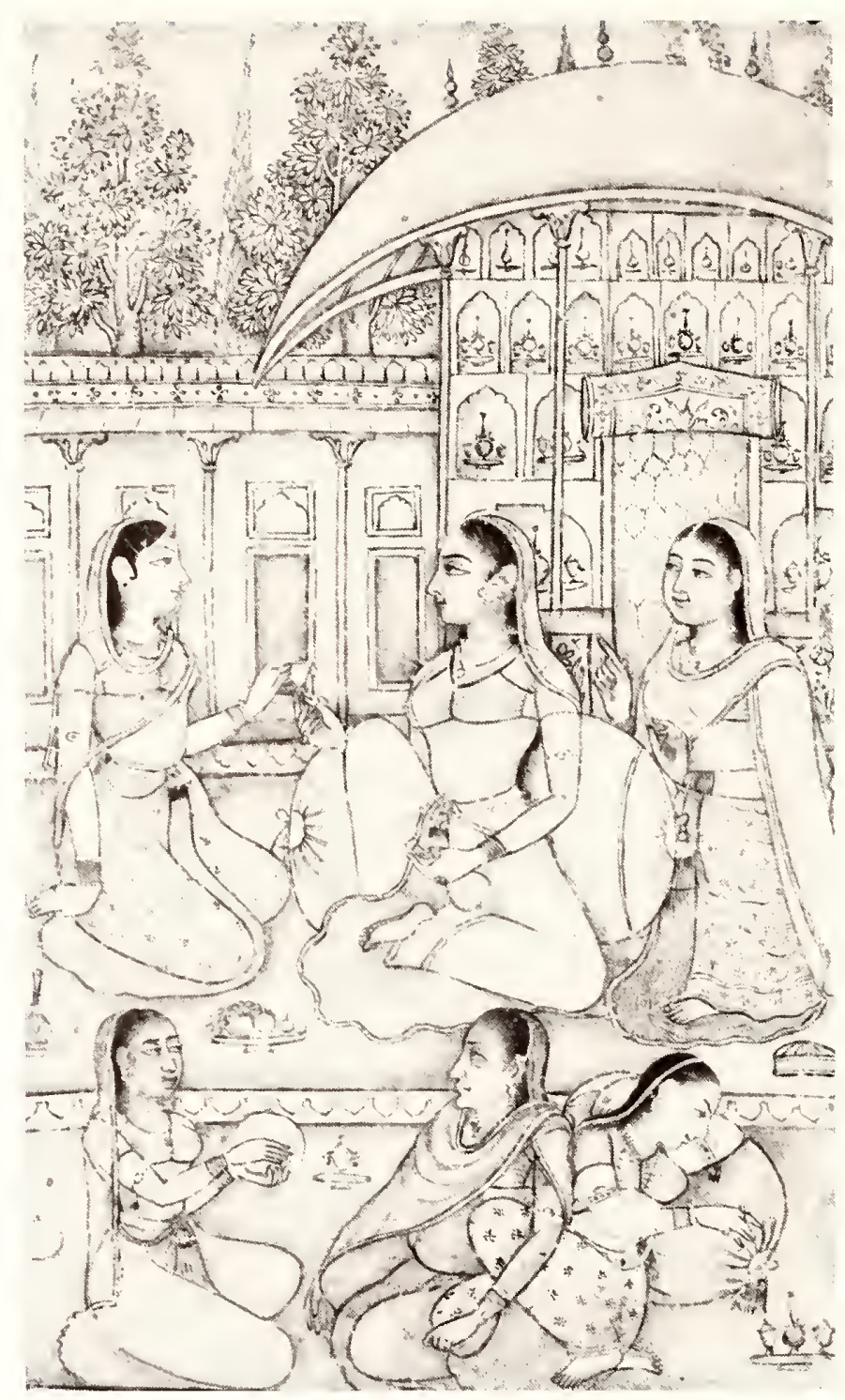




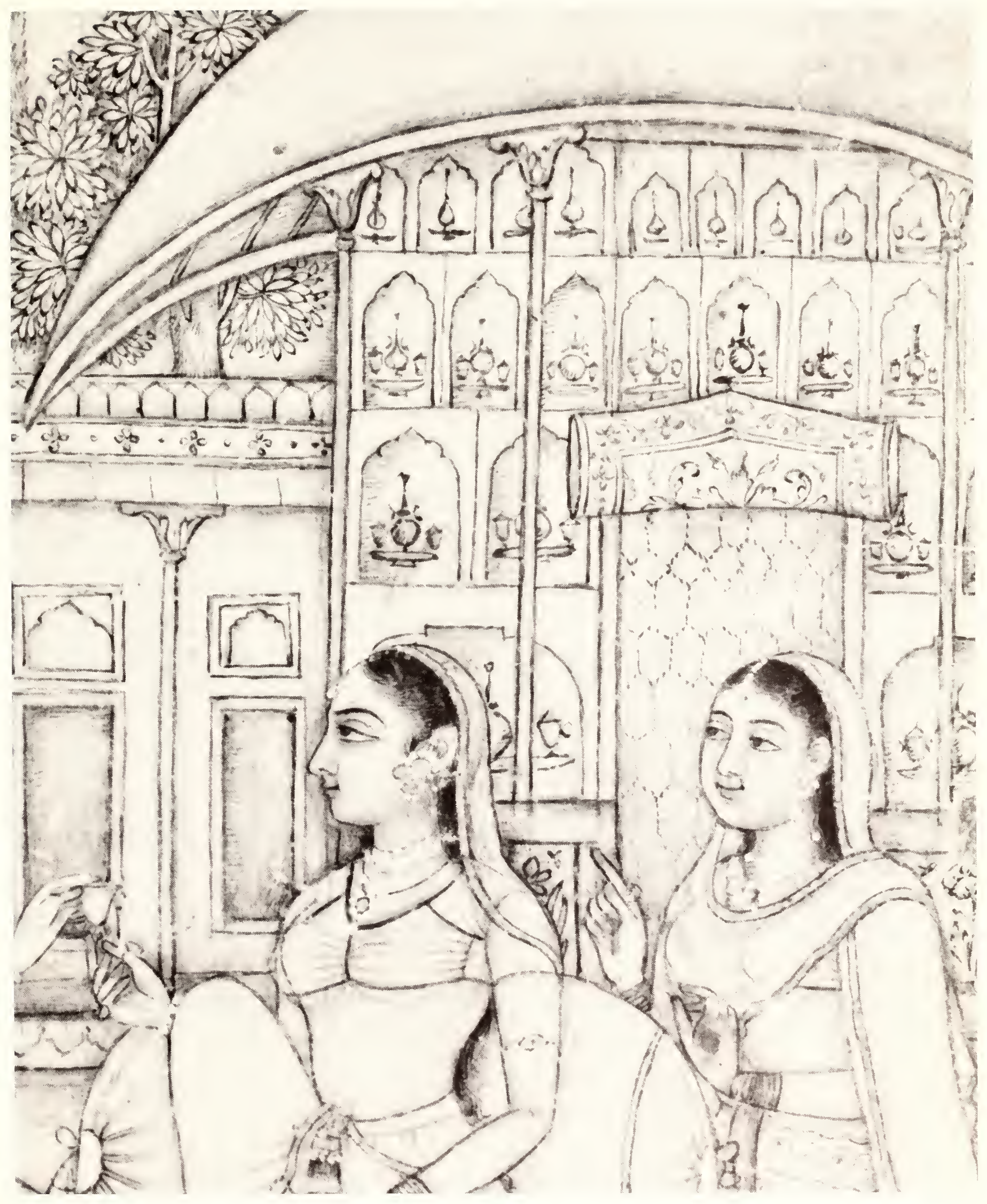




\section{Portrait of Nadir Shah}

India, Mughal school, mid-18th century

Black line on paper; tinted with red, mauve, green, yellow, brown and white

Page: $37.9 \times 23.9$

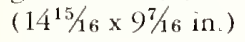

Drawing: $19.7 \times 10.4 \mathrm{~cm}$

$$
(73 / 4 \times 41 / 16 \text { in. })
$$

07.256

The portrait, mounted on a blank cardboard, is decorated with coarsely executed marbled paper which has been added around the drawing at a later date. The original sheet has been slightly trimmed and now is framed by gold, red and green lines.

The portrait is executed in black with only the face, headdress and fur collar depicted in color. The figure is shown in profile, seated against a thick cushion holding a sword across his knees. An inscription identifying the subject appears below and states that it is the representation of Nadir Shah

The unusual headdress, possibly Nadir Shah's personal choice for the Afsharid rulers, is a tall yellow cap embroidered with green leaves and red blossoms; a pearl garland decorates the crown which is softly gathered at the top and mounted with a feather attached by a ruby pin; the upturned split-rim is painted mauve.

Nadir Shah is represented with an unfaltering stern expression, true to the reputation of this remarkable man who saved Iran from foreign domination, expanded its boundaries and invaded India in 1738-39. The strong profile of the subject is accentuated by the soft-brown fur collar of his coat and pale-green shirt. This is most likely a contemporary portrait executed shortly after Nadir Shah's Indian campaign

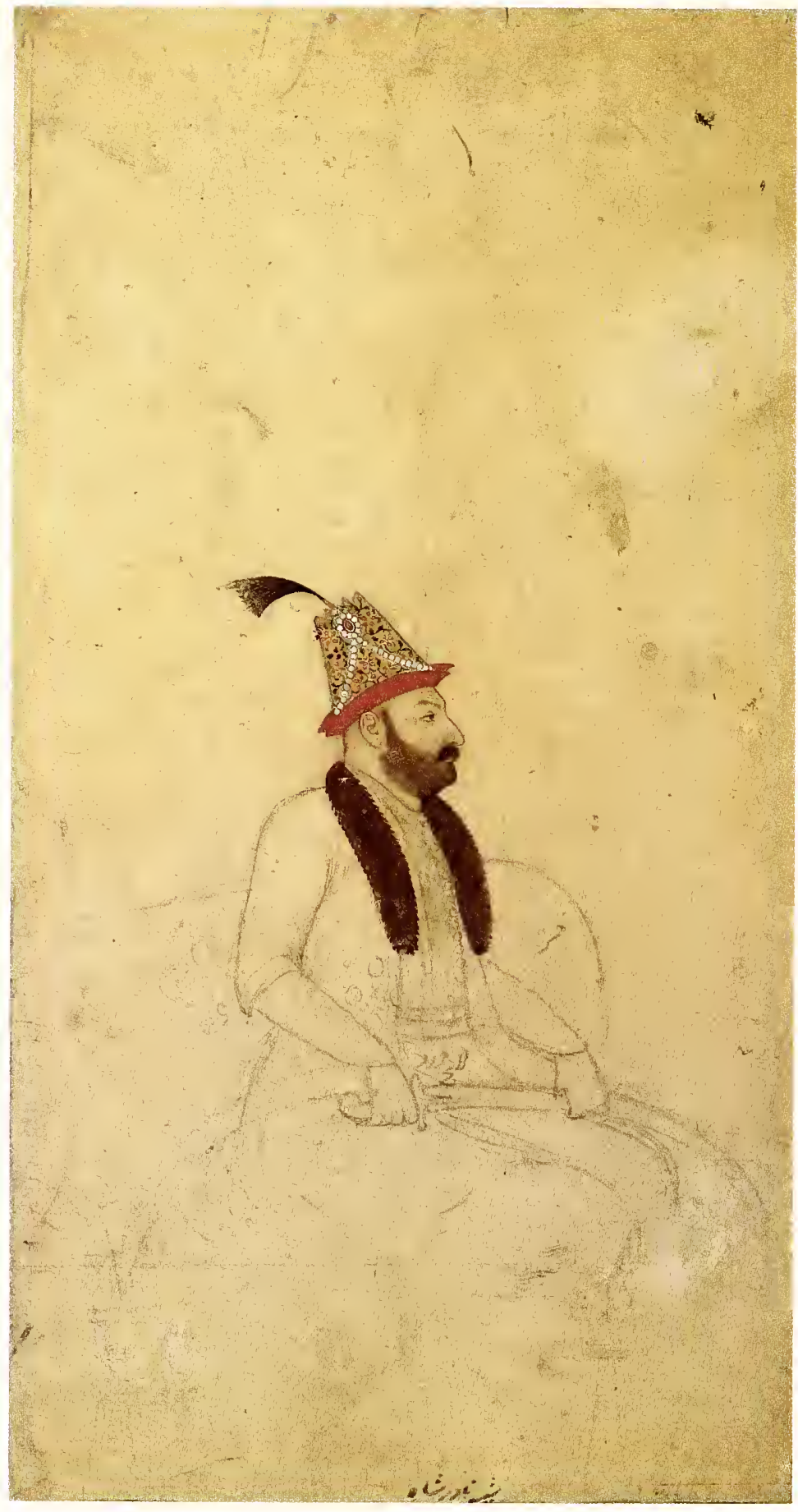




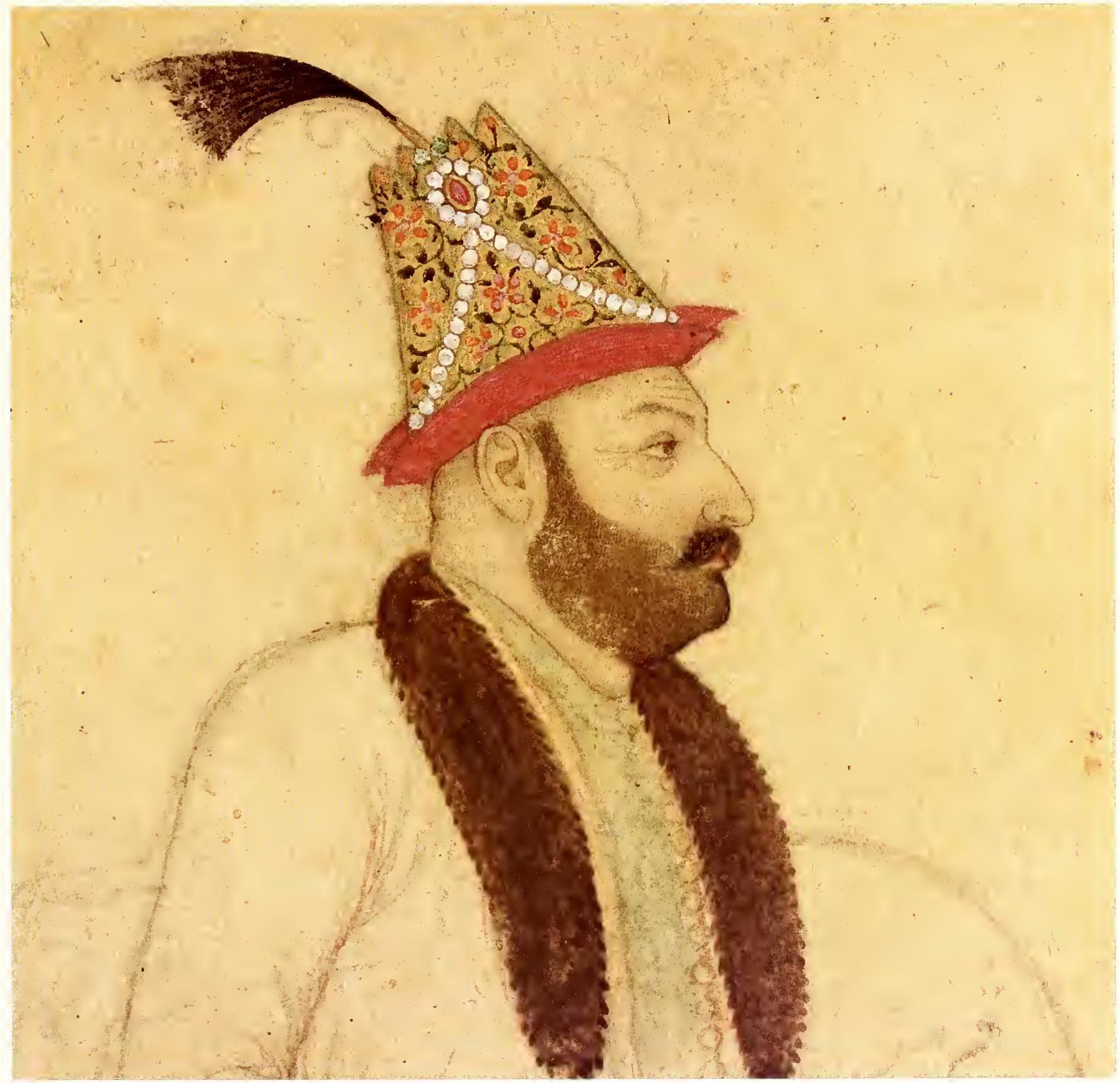

Nadir Shah, born in 1688 , belonged to the Turkmen tribe of the Afshars. He entered the services of Shah Tahmasp II and fought valiantly against the Afghans in the east and the Ottomans in the west, defending the remnants of the Safavid state After being proclaimed king of
Iran in 1736 , he immediately set out to capture Kandahar and then marched onto Delhi. In the decisive battle of 1739, Nadir Shah was the victor. He reinstated the Mughal emperor, Muhammed Shah, in return for the provinces north of the Indus plus a phenomenal sum of money and treasures, including the renowned Koh-i Nur diamond and the fabled Peacock Throne. The amount levied was so large that the Iranians were exempted from taxes for three years. Nadir Shah was assassinated in 1747 in an uprising instigated by a group of Afshar and Kajar chiefs. 


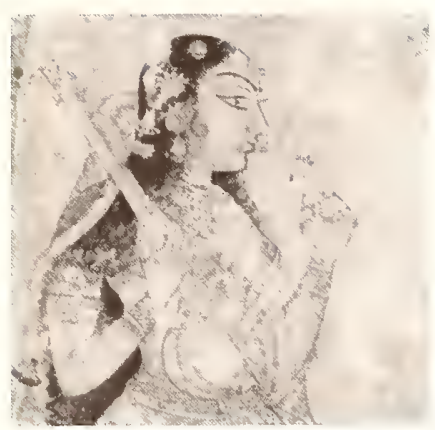

\section{Deccani School}

The sultans of the Deccan, the high plateau in the southern portion of India, were late arrivals like the Mughals. Among the first Muslims to rule this region were the Bahmanids (1347-1527) whose capital at Bidar became a major center of learning. The Bahmanids set up diplomatic and cultural exchanges with the Ottomans, employing Turks, Persians and Arabs in their courts.

When the effective rule of the Bahmanids disintegrated at the end of the 15th century, a major portion of the Deccan became divided between five dynasties. The Barid-Shahis, who replaced the Bahmanids in Bidar, fell to the Adil-Shahis of Bijapur in 1619; the Imad-Shahis of Berar (1485-1572) were eventually absorbed by the Nizam-Shahis; the Adil-Shahis of Bijapur (1490-1686), who were related to the Ottoman sultans, were particularly interested in the development of the arts and invited scholars and painters from Turkey and Iran to their courts; the Nizam-Shahis (1491-1633) ruled in Ahmednagar and vicinity; and the Kutb-Shahis (1512-1686), who controlled Golconda, were the descendants of the Karakoyunlu Turkmens.

Despite the continuous rivalries and endless wars among these states, Deccani painting flourished between the middle of the 16th century until the Mughal conquest of 1686-87, the most prolific studios being in Bijapur, Ahmednagar and Golconda. The artists created remarkable works which reveal a mixture of local traditions, Ottoman, Safavid and Mughal court styles, and to some extent the influence of Western painting. Portraiture was a predominant genre although occasional Ragamala series and Christian themes were also produced (nos. 76-77). 
76. Woman Holding a Vina India, Deccani school, ca. 1670

Black line on paper

$16.6 \times 11.3 \mathrm{~cm} .\left(6^{9} / 16 \times 47 / 16 \mathrm{in}.\right)$ 46.27

The drawing, which has been stained and repaired around the edges, represents a seated woman holding a vina, the traditional string instrument of India. She has stopped playing momentarily and smells a flower while watching the cautiously approaching deer which has been attracted by the music.

Clusters of flowers cover the ground, and three different types of trees grow in the background. The largest, framing the seated woman, has blossom-like leaves; several birds appear amidst the leaves while two squirrels run up the trunk. A castle rises behind the hills on the upper right.

The composition indicates that the scene illustrates the Todi Ragini from a Ragamala series. The Ragamala, literally translated as a Garland of Musical Modes, is a codification of Hindu music which is expressed with verses and pictorial representation. It symbolizes the aesthetics of Hindu music and contains a great number of variations although traditionally there are six fundamental ragas, or "melody moulds," each of which contains five raginis, or modes. The Todi Ragini is represented by a woman playing the vina, attracting deer.

The drawing, rendered only in soft black lines, is extremely refined with delicate strokes defining the figure, animals and landscape elements. The artist has successfully captured the sentiment expressed by the musical mode, representing a pictorial version of the theme.

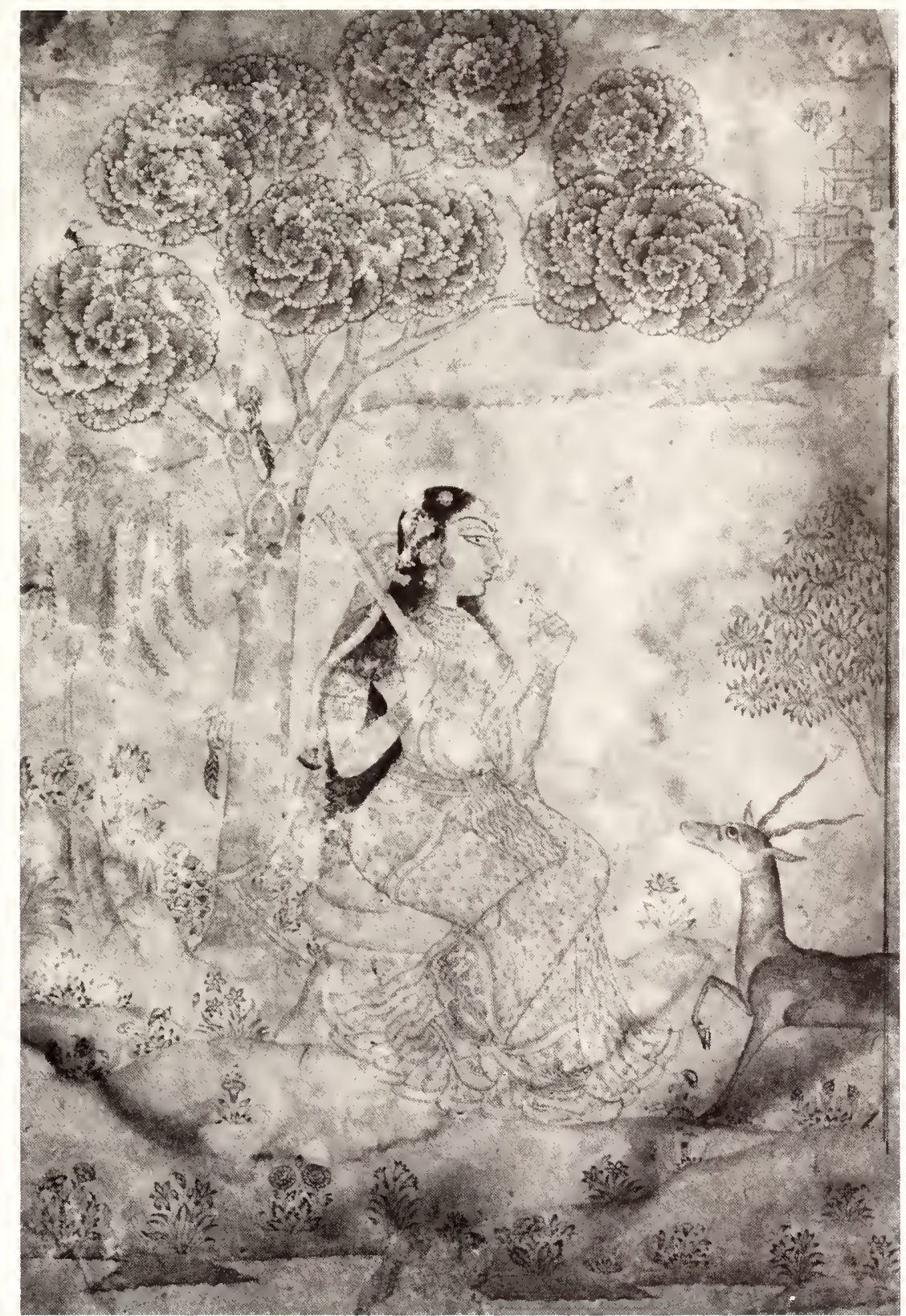




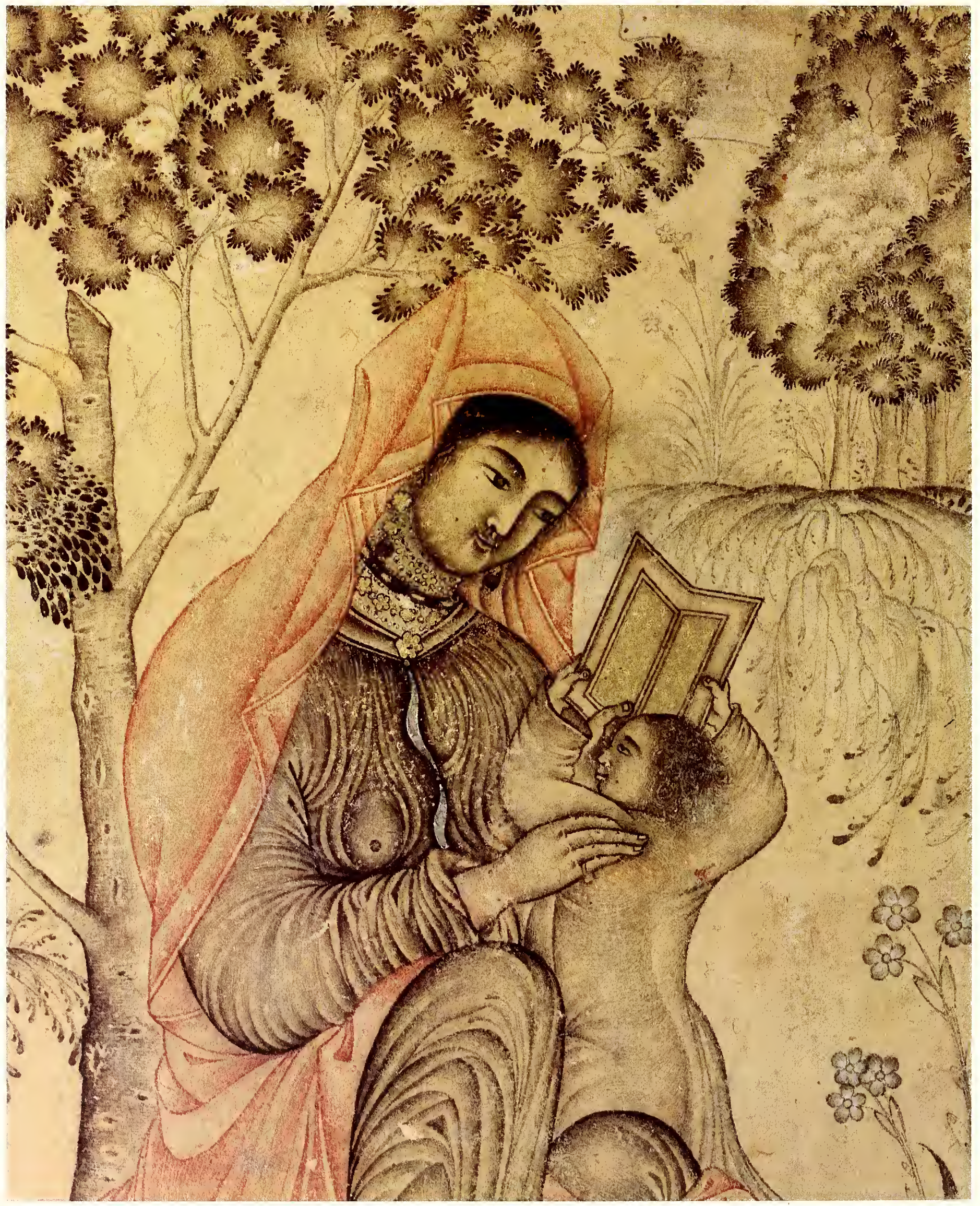


77. Virgin and Child

India, Deccani school, ca. 1625

Black line and gold on paper; tinted with red, pink and white Page: $36 \times 23 \mathrm{~cm}$ $(143 / 16 \times 91 / 16$ in.)

Drawing: $16 \times 11.1 \mathrm{~cm}$ $(65 / 16 \times 43 / 8$ in. $)$ 07.155

The tinted drawing representing the Virgin and Child has been mounted on blank cardboard with several red and blue borders used to frame the scene. The Virgin Mary is shown seated beneath a tree with the Christ Child who holds up a book. They are surrounded by bunches of leaves and flowers and richly foliated trees with streams of branches drooping down the soft hills.

The execution of the figures is highly stylized with crisply drawn drapery forming decorative folds The Virgin wears a long flowing scarf tinted pink, her dress is lined in red and slightly open at front, revealing a white undershirt; elaborate gold jewelry adorns her neck and ears. The figures were obviously inspired by European examples but executed in a local style and technique Their facial types also suggest a native tradition.

The soft brush strokes in the landscape with delicately drawn leaves and branches contrast with the rigidity of line seen in the figures Obviously the artist was more at ease executing the background and labored over the figures

Deccani artists were quite familiar with Christian themes; since the Portuguese had established a colony in Goa in 1510 , Jesuit missionaries and European travelers were constant visitors. This drawing is attributed to the school of Bijapur which was in close contact with Portuguese settlements.

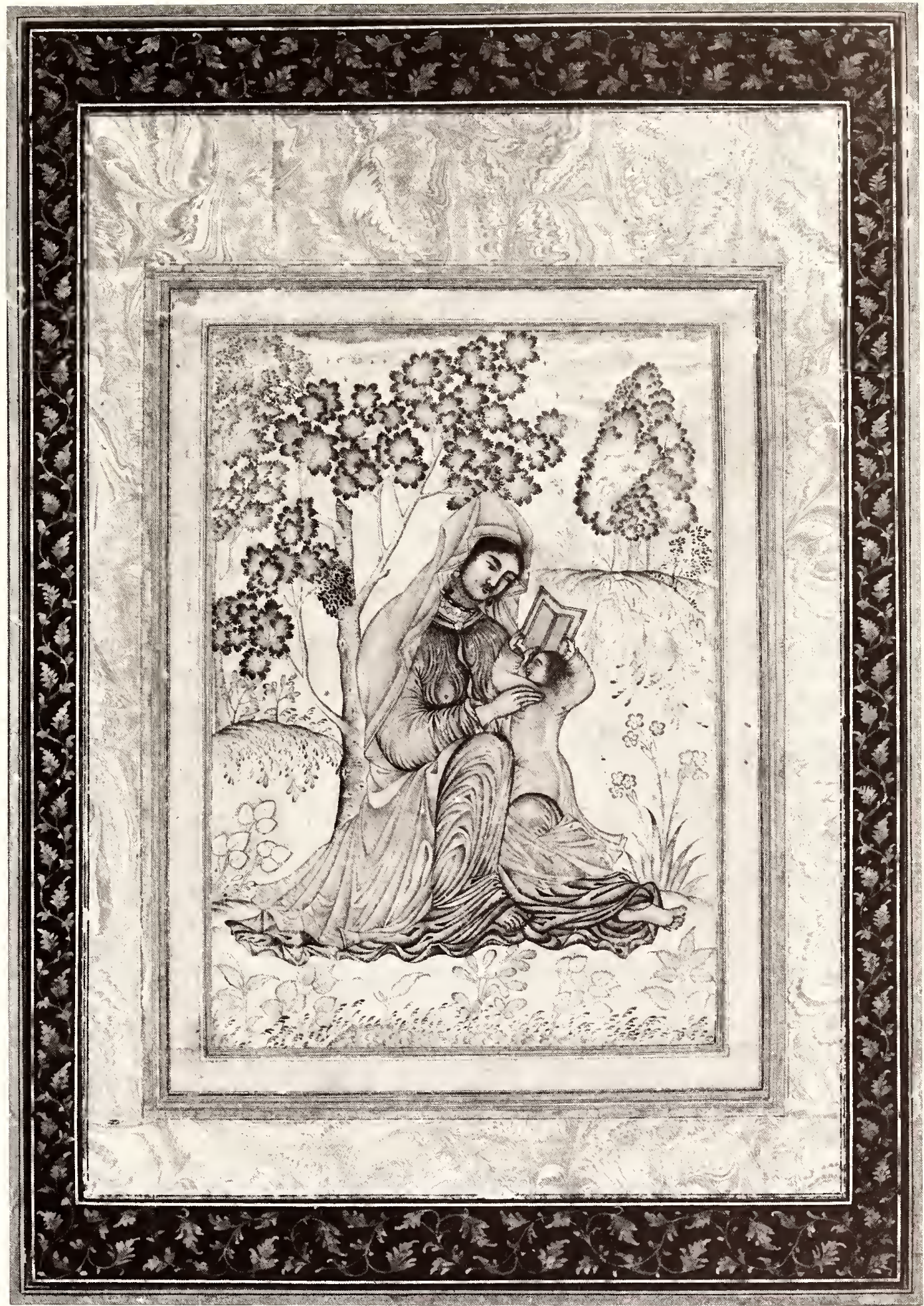




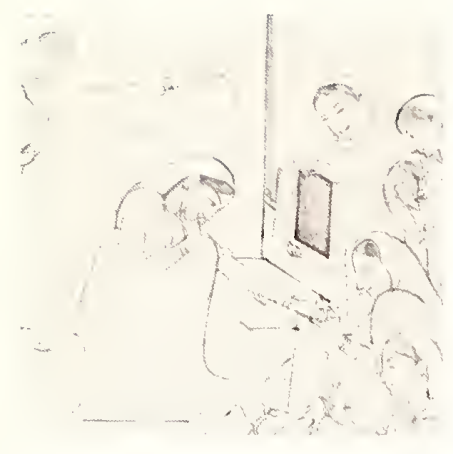

Rajput School

The Rajputs, the Hindu rulers of India, were renowned for their brave and chivalrous conduct as well as for their strong tribal ties which prevented them from uniting against the foreign invaders. The Rajput princes established a number of states in Rajastan and the Punjab Hills which paid tribute to the Mughals at the height of their empire, between the early 17 th and the mid-18th century. After the slackening of Mughal authority, the Rajputs became more or less autonomous until the arrival of the British in the early part of the 19th century.

Rajput painting in the Punjab Hills developed after the 17 th century, most likely stimulated by the close contact with the Mughal court. The painting studios flourished during the following two centuries and produced remarkable portraits and series of religious paintings with an overwhelming preference for the Krishna cycle. ${ }^{63}$ The court painters of Kangra were particularly active during the second half of the 18 th century and developed an indigenous style which reached its height under the patronage of Sansar Chand (1775-1823). ${ }^{64}$ The raja and the members of his family commissioned a great number of portraits, single-page paintings and voluminous series narrating the life and teaching of Krishna and his romance with Radha.

One fascinating series was devoted to the mystical romance of Princess Damayanti who falls in love with Nala, the young king of Nishadha, originally written around the middle of the 12 th century by Sriharsha. The poem relates the meeting of the two protagonists, their wedding, misfortunes and ultimate happiness, stressing the lifelong devotion of the lovers whom the gods had destined should be together.

The story was particularly significant to Sansar Chand, who fought valiantly against the Afghan invasion and ruled supreme in the Kangra Valley for two decades; he himself had a passionate love affair with the beautiful Nokhu whom he abducted and later married. The hero and heroine of the Romance of Nala and Damayanti were probably associated with the patron and his wife and the setting of the story inspired by the raja's palaces. 


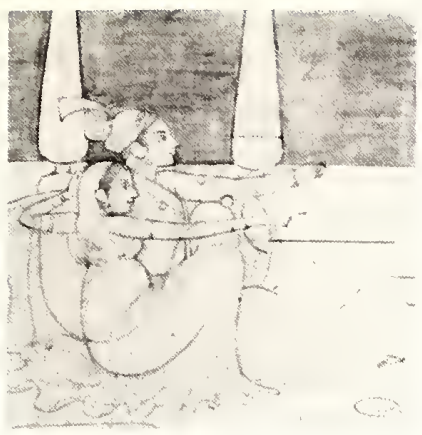

Several sets of the Romance of Nala and Damayanti were executed between 1790 and 1810 , each set conceived as a series of some 100 paintings. Some of these sets were completed while others contain only portions of the story; the illustrations in a couple of the sets are merely sketched and left unfinished.

One of the incomplete and unfinished sets was made around 1790 or 1800 and contains about 47 illustrations owned by various American collections, including the Freer Gallery of Art (nos. 78-82). ${ }^{65}$ The scenes illustrate the second part of the Romance of Nala and Damayanti and are executed in a technique which is particular to this series. The illustrations are sketched in sanguine, or a broad red line, over which a second black line was drawn; a semitransparent white ground was applied over these lines, covering the entire sheet, serving as a primer and facilitating corrections; then fine brush strokes completed the drawing which was now ready for the final coloring rendered in gouache, or opaque watercolor; color was first applied to the background and then to the figures.

The illustrations are on rectangular sheets of paper approximately 29.2 by 40 centimeters ( $11 \frac{1}{2}$ by $153 / 4$ inches) with a border of 3.5 centimeters ( $13 / 8$ inches) left blank on four sides; the dimensions of the drawings average 22.2 by 33.5 centimeters $(85 / 8$ by $13 \% 16$ inches). This format and size are common to all the existing sets.

The Freer sketches are executed in fine black lines on a white ground with only the preliminary tints applied to the background. The figures are rendered with great charm, gliding through the scenes with serenity and grace. Although a firm outline is used, there is an ease of motion with the elements flowing into one another. The Nala-Damayanti scenes represent the grand style of the Rajput school in the Kangra Valley. 
78. Toilet of Damayanti

From the Romance of Nala and D.amayanti

India, Rajput school, ca $1790-1800$

Black line over white ground on paper; tinted with red, mauve, green and yellow

Page: $29.2 \times 40 \mathrm{~cm}$. $\left(11 \frac{1}{2} \times 15 \frac{3}{4}\right.$ in.)

Drawing: $22.3 \times 33.7 \mathrm{~cm}$. $(83 / 4 \times 131 / 4$ in $)$

30.85

The depiction of several consecutive episodes in the drawing is characteristic of the Nald-

Damayanti illustrations. The scene takes place in Damayanti's palace prior to her marriage; it shows the princess being washed and groomed and departing for the wedding pavilion. The beautiful Damayanti, half nude with her long black hair loose, is seated on a stool in the center of the courtyard, some of her maidens bathe her while others hold up a curtain for privacy

Two of the maidens hold ewers, one pouring a ewer's contents over Damayanti's head, another pair fills the containers from large jars while two others hold a towel and a mirror. Placed on the ground in front of Damayanti are various bathing utensils such as jars, basins and bowls

The next vignette depicts Damayanti being groomed and admired by her maidens in the pavilion which appears on the upper left. The attendants cluster around her: some paint her toenails and fingernails; others hold up a mirror, carry cosmetics on trays, select jewelry from a chest and shield her with a scarf; an elderly woman carries an incense burner. Two musicians outside play the vina and drum; an attendant walks by with a covered tray

In the kitchen on the upper right, the cooks are preparing for the wedding feast, cooking rice in a large kettle, kneading dough and bringing in supplies. The wedding pavilion appears behind the screen in the background, its open roof decorated with birds

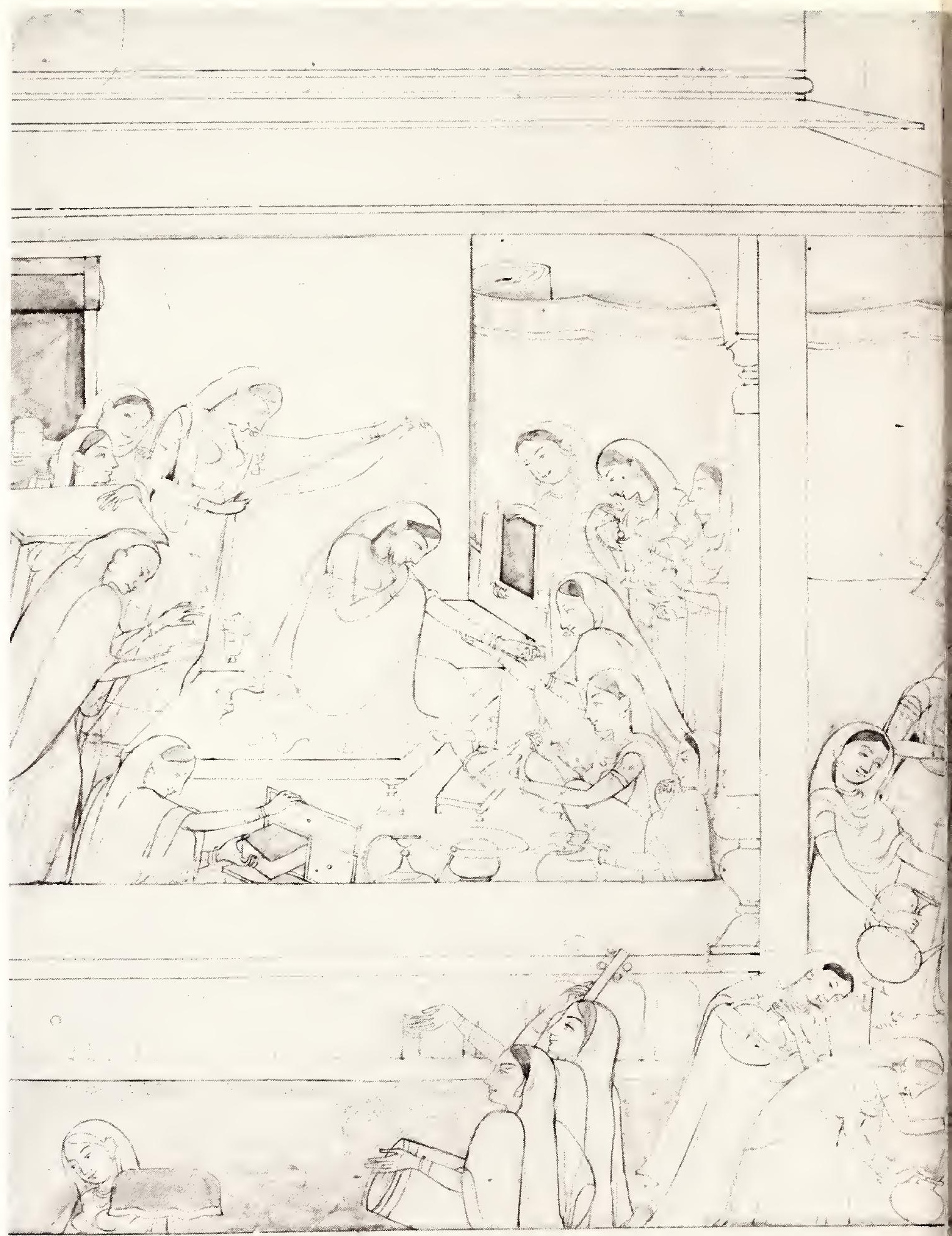



78. Toilet of Dumayanti

Dumalyanti

India, Raspur school.
1790 -1800

Black line over white ground on

puperi; rinred with red, mawe

kereen and yellow
Page: $29.2 \times 40 \mathrm{~cm}$.

Drawing: $22.3 \times 33.7 \mathrm{~cm}$

$(83.4 \times 131 / 4$ in.

The depucrion of several consced

che episodes in rhe driw ing is

haracecerisstic of the Nala-

Damaysant illustrurtons. The

pilace prior ro her marriage: it

thows theomed and departiny for

he wedding pavil on The beauri-

Damayanri, half nude wirh her

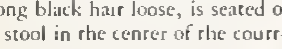

yardi some of her maldens barh

for privacy.

wo of rhe maidens hold ewers.

Damaysanti's head; another parr

fills the contaners from large jars

mirror. Placed on the ground in

fonr of Damayanri are various

sins and bowls.
sarhing urensils

The next vignetre depicts

dmired by her maidens in the

avilion which appears on the

wpper be The atrendanrs cl

hold up a mirror, carry cosmerics

hesc and shield her wirh a seaf

ense burner Two musicians ou side play the vina and drumi; an eray.

In the kirchen on the upper right, the cooks are preparing for the ing pavilion ippears thehind the screen in the back ground, its

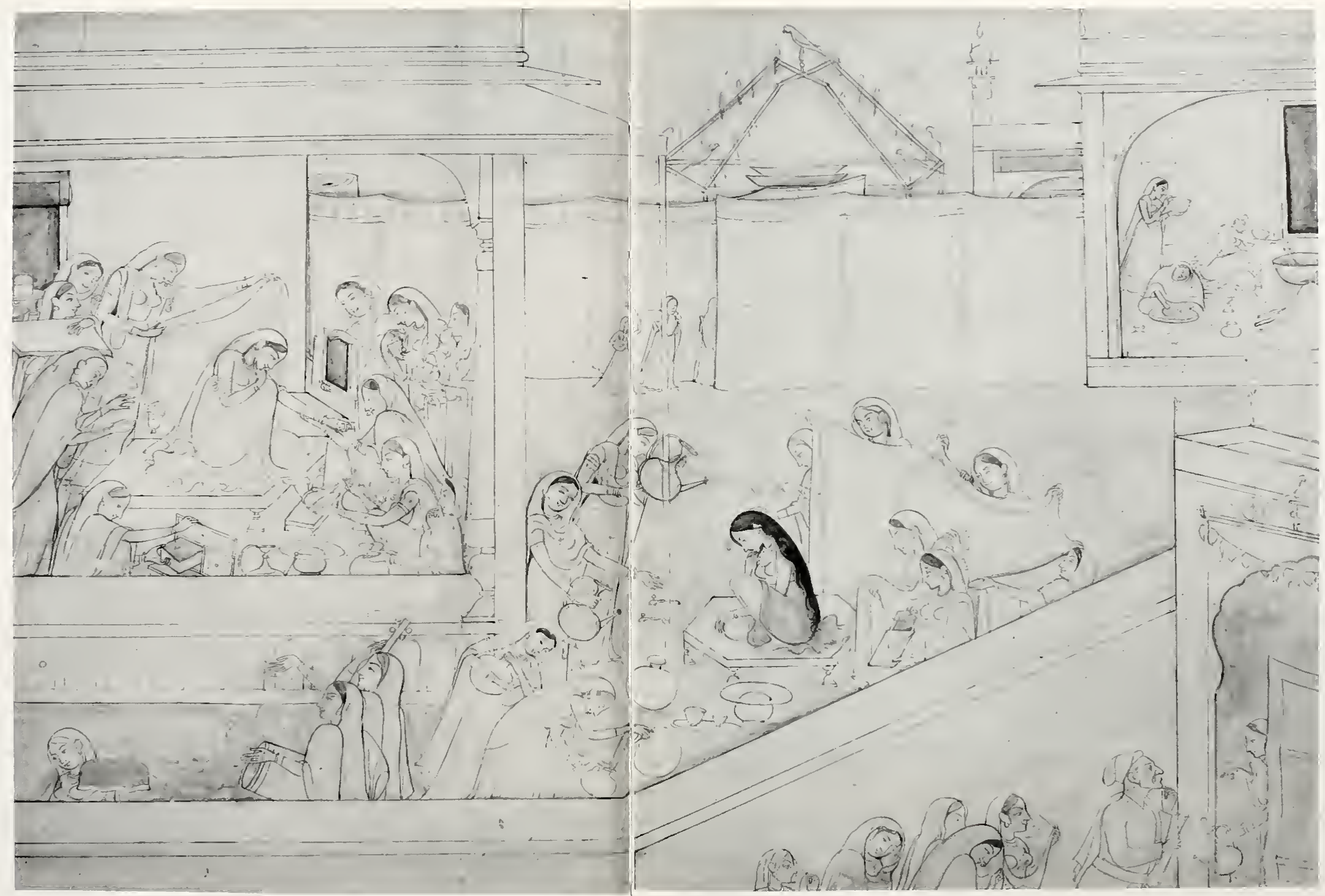




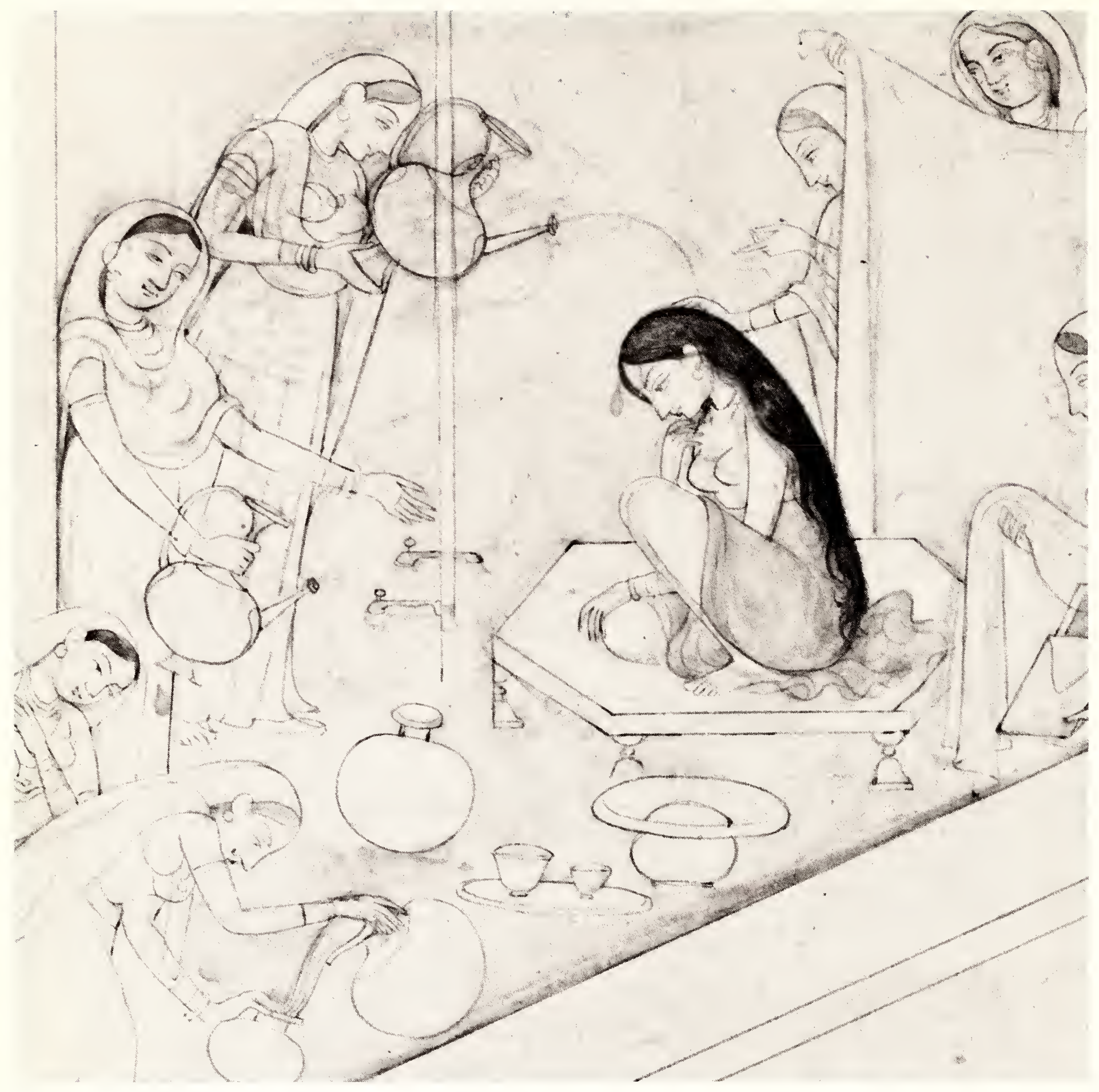

The departure of Damayanti is depicted on the lower right. A raaiden appears at the door, handing to the priest an ewer to be used during the ceremonies Damayanti, her head bowed in modesty, is attended by several friends on her way to the wedding pavilion.

Black lines have been used to go over or to correct the original sketch, which is barely visible under the semitransparent white ground. The preliminary waskès have been applied to certain portions of the scene, such as the courtyard, curtains, a few vessels and Damayanti's robe. 
79. Marriage of Damayanti

From the Romance of Nala and Damayanti

India, Rajput school, ca. 1790- 1800

Black line over white ground on paper; tinted with red, mauve, green and yellow

$22.1 \times 16.3 \mathrm{~cm} .\left(8^{11 / 16 \times 63 / 8 \mathrm{in} .)}\right.$ 23.11

The illustration, damaged and trimmed along the edges, has been cut in half and includes only the left portion of the scene. The drawing represents the wedding ceremonies of Nala and

Damayanti, who are seated in the marriage pavilion which was seen in the previous episode. In front of the couple is the priest Gautama who ties their hands with a cord, symbolizing the marriage knot. The elderly figure bearing a crown next to the priest is King Bhima, the bride's father. He brings to his new son-in-law several gifts, including the miraculous sword of Durga, a dagger and a covered box on a tray which most likely contains the wish-fulfilling wreath of gems originally given to him by Siva.

The maidens around the central figures carry garlands, trays, bottles and flaming torches. The woman bending over the bride is probably Kala, Damayanti's faithful companion. Spread in front of the bridal couple are various ceremonial vessels, such as bowls, basins and vases.

In the foreground, outside the enclosure, are attendants and torchbearers who accompany an elephant laden with baggage and a chariot drawn by a pair of horses, also given to Nala by King Bhima.

This illustration has also been corrected and the original lines under the semitransparent white ground are still visible; preliminary colors have been added to the background.

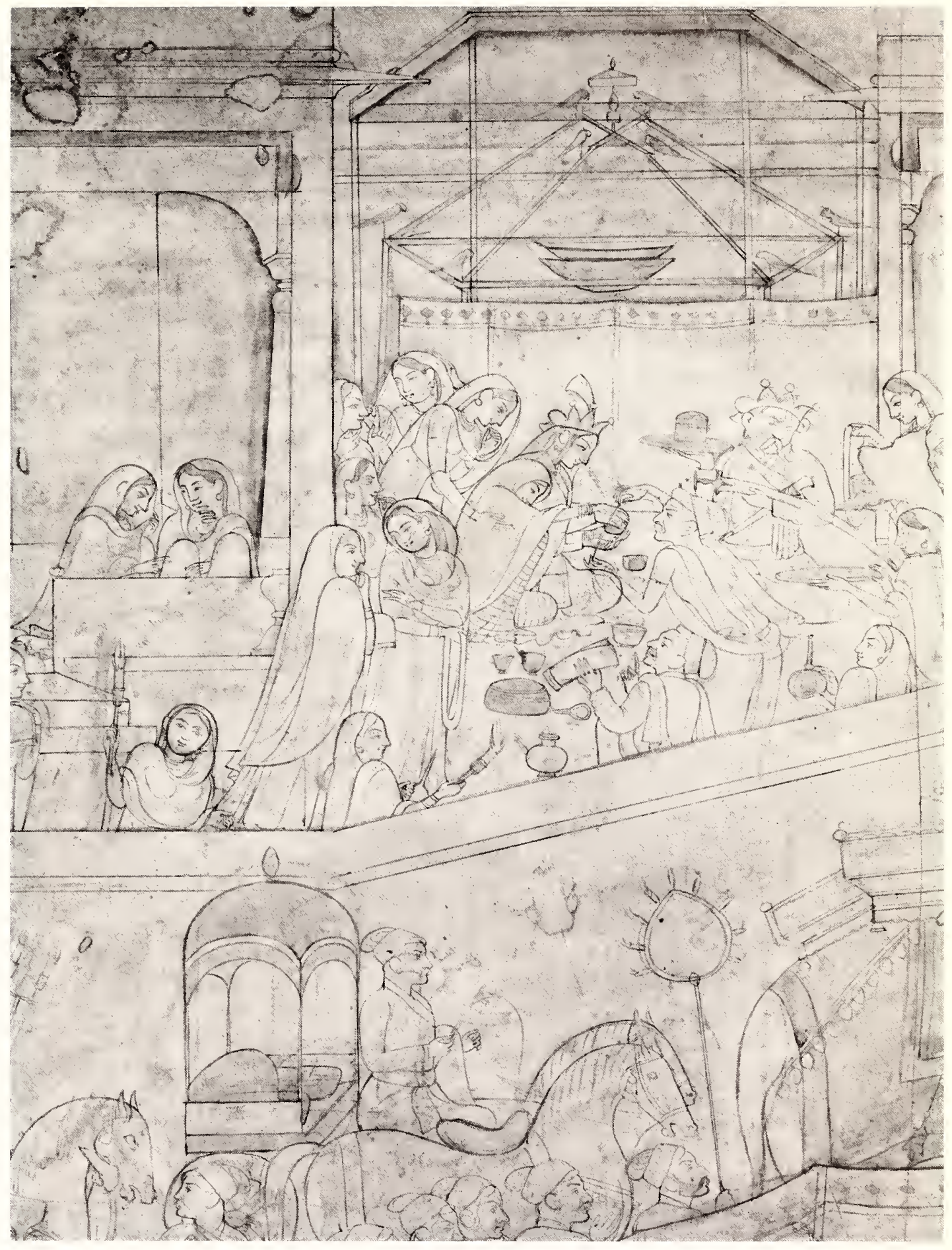


80. Departure for Nisadha

From the Romance of Nala and Damayanti

India, Rajput school, ca. 1790-1800

Black line over white ground on paper; tinted with red, mauve, green, yellow and white

Page: $29.2 \times 40 \mathrm{~cm}$ (I $1 \frac{1}{2} \times 15 \frac{3}{4} \mathrm{in}$ )

Drawing: $22.2 \times 33.5 \mathrm{~cm}$. $(83 / 4 \times 133 / 16$ in. $)$

23.10

This episode takes place after the wedding of the hero and herome and represents Damayanti departing from her father's house to go with her husband to his kingdom of Nisadha. Damayanti, riding in her palanquin, is leaving the courtyard accompanied by King Bhima and Prince Dama, both of whom bear crowns. Also joining the retinue are scores of Damayanti's maidens, some holding fly whisks and the others mourning her departure. A group of musicians heads the procession, which moves through the screen rolled back by the attendants and leaves through the palace gate

Nala is seated in the balcony on the upper left, conversing with a man while being fanned with a fly whisk. Other maidens watch the procession from the cantilevered windows of the patace

The narration of the departure continues in the fields out side the palace. Nala, sitting in the chariot given by his father-in-law, is moving along with his entourage and baggage, preceded by flagbearers and musicians. Beyond the hill is Damayanti's palanquin and her train, which includes servants bearing large boxes on their heads or carrying huge caskets by poles, her mounted attendants and elephants, as well as her wedding bed and throne.

The highly crowded scene contains more pretiminary colors than the previous drawings with the sky, hills and details of the bagrgage executed in pale tones

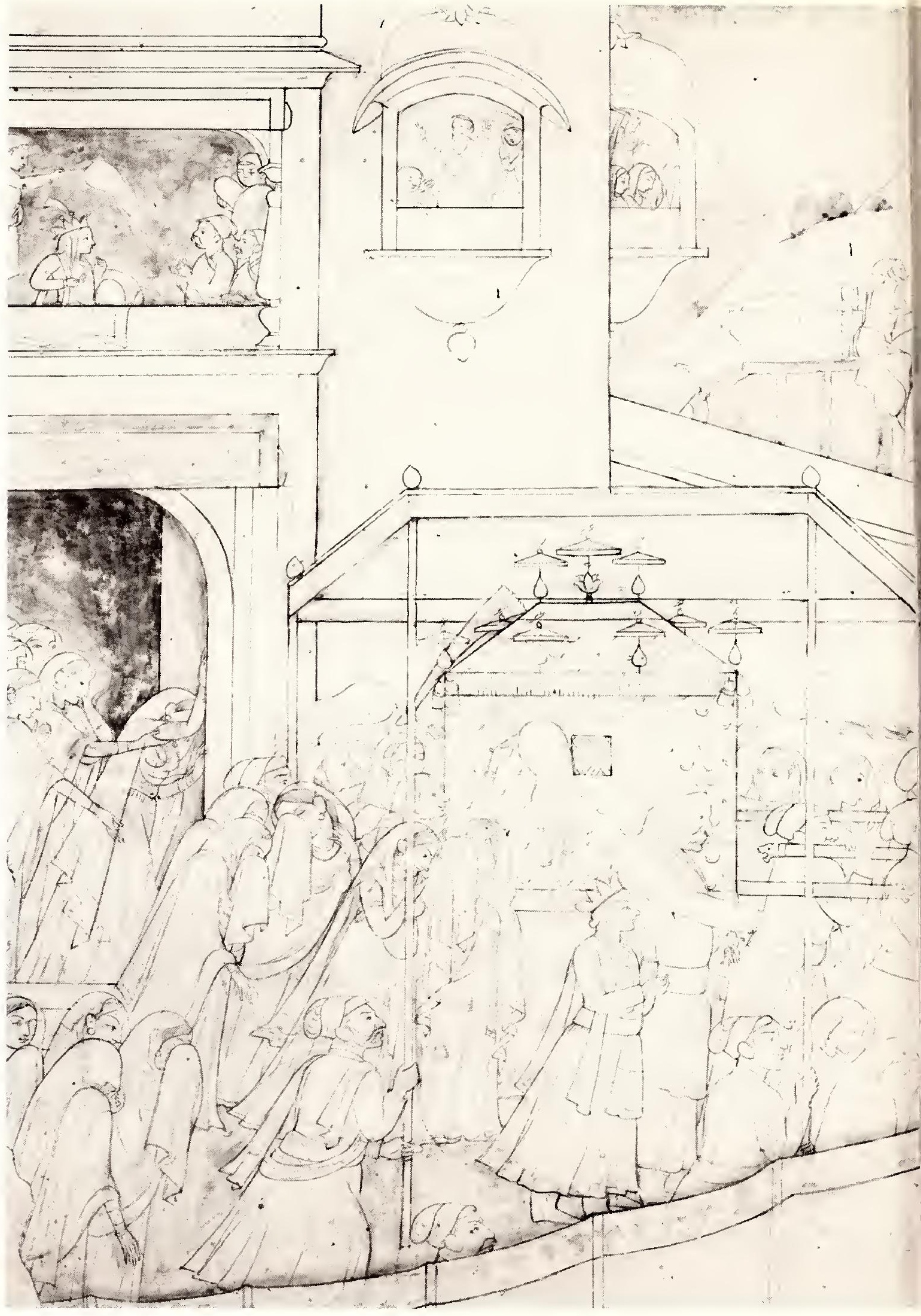






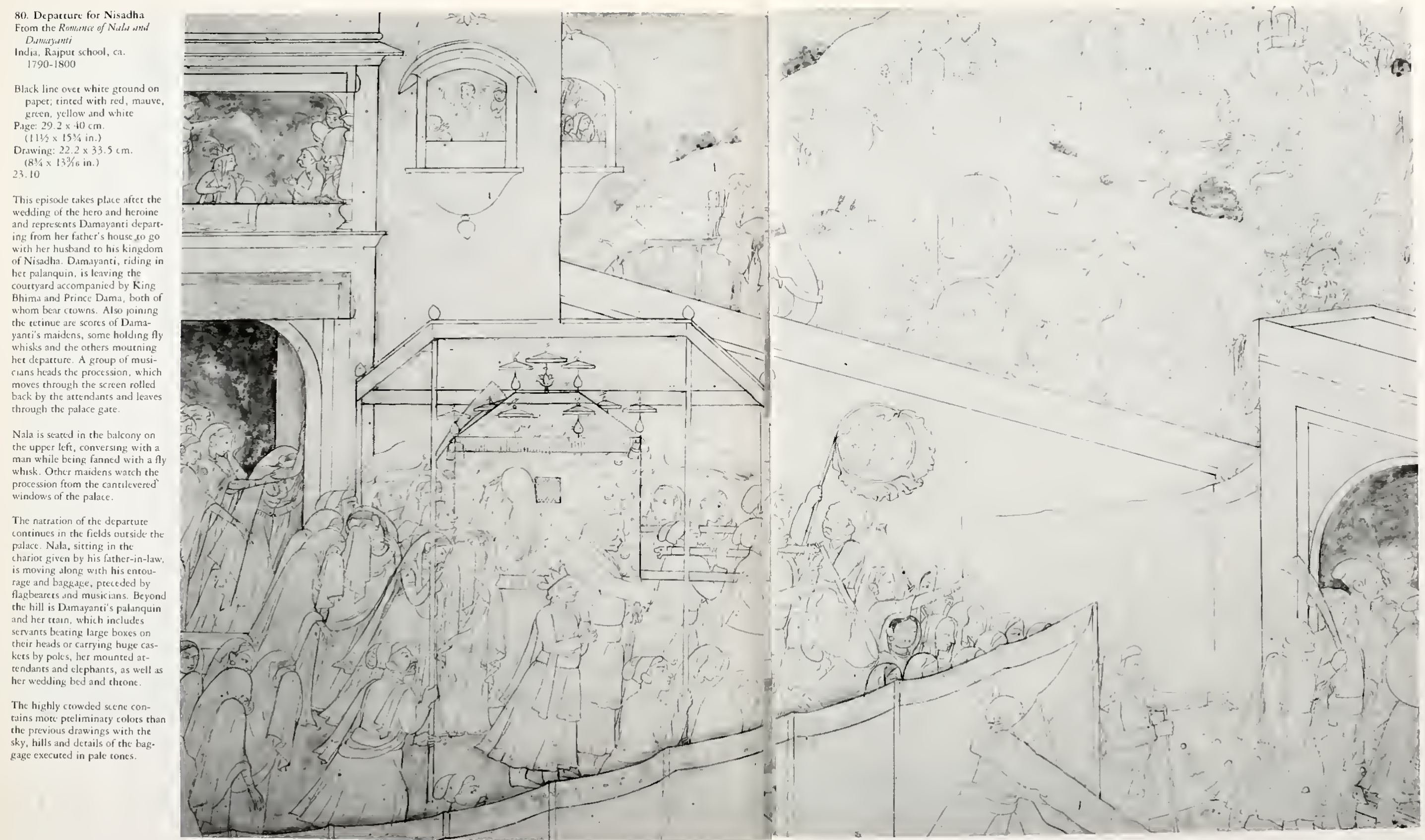


81. Damayanti with the Lotus From the Romance of Nala and

Damayanti

India, Rajput school, $\mathrm{ca}$. 1790-1800

Black line and silver over white ground on paper, tinted with mauve, blue, green, yellow and beige

Page: $29.2 \times 39.8 \mathrm{~cm}$ (111/2 $\times 15^{11 / 16 \text { in }) ~}$

Drawing: $22.2 \times 33.4 \mathrm{~cm}$. $(83 / 4 \times 131 / 8$ in $)$

23.13

After Nala and Damayanti settle in Nisadha, they spend the ir days in blissful happiness, proving their unwavering devotion to each other. The scenes representing the great love that exists between the lovers are set within the tranquility of their palace, its serene atmosphere enhanced by the elegant figures and their lyric postures

In this episode Nala is jesting with Damayanti and Kala. He has given Damayanti a lotus which she considers more valuable than anyching else in the world since it was from her beloved. The couple ate seated in an arcaded pavilion in front of which is a fountain with three ducks walking around. Several maidens stroll in the courtyard, conversing or cartying trays into the two structures on either side. Rows of trees border the fountain and appear behind the high walls of the enclosure.

In the center of the scene are Nala and Damayanti, seated on a couch. Nala rests his arms on the two cushions on his hap while conversing with Damayanti who bends her head in modesty, holding the lotus in her hand as Kala stands beside her. Scattered around the floor are a low table with small bottles, a spittoon for betels, a jar and a covered bowl.

The setting was likely inspired by the palaces of Sansat Chand, the patron of the work, and represents the luxurious structures of the Kangra Valley. These palaces with high walls - enclosing a complex of arcaded pavilions placed around the couttyards adorned with gardens, fountains and pools-teflect the architectural traditions estabtished by the Mughals in the 16th and 17 th centuries

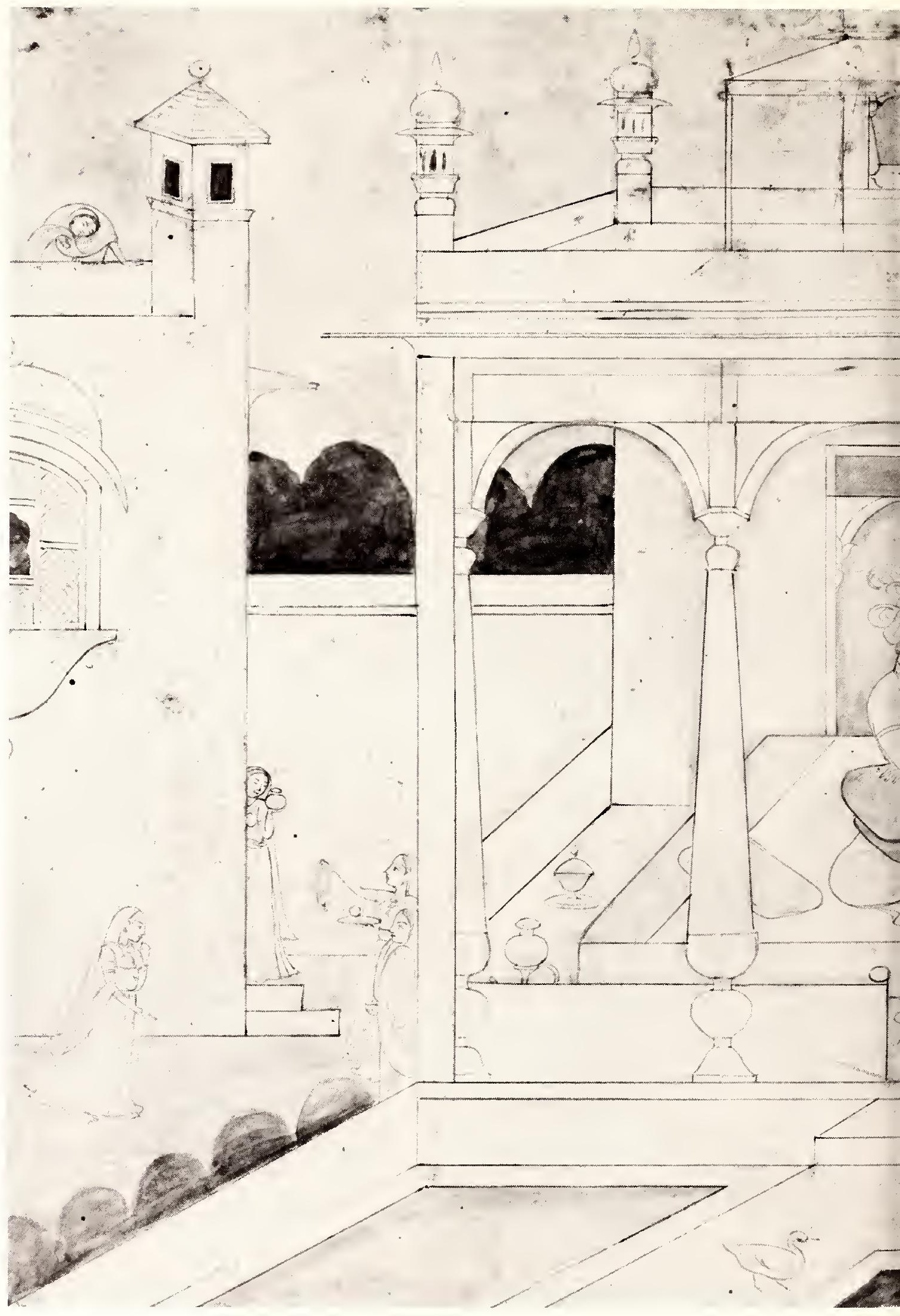




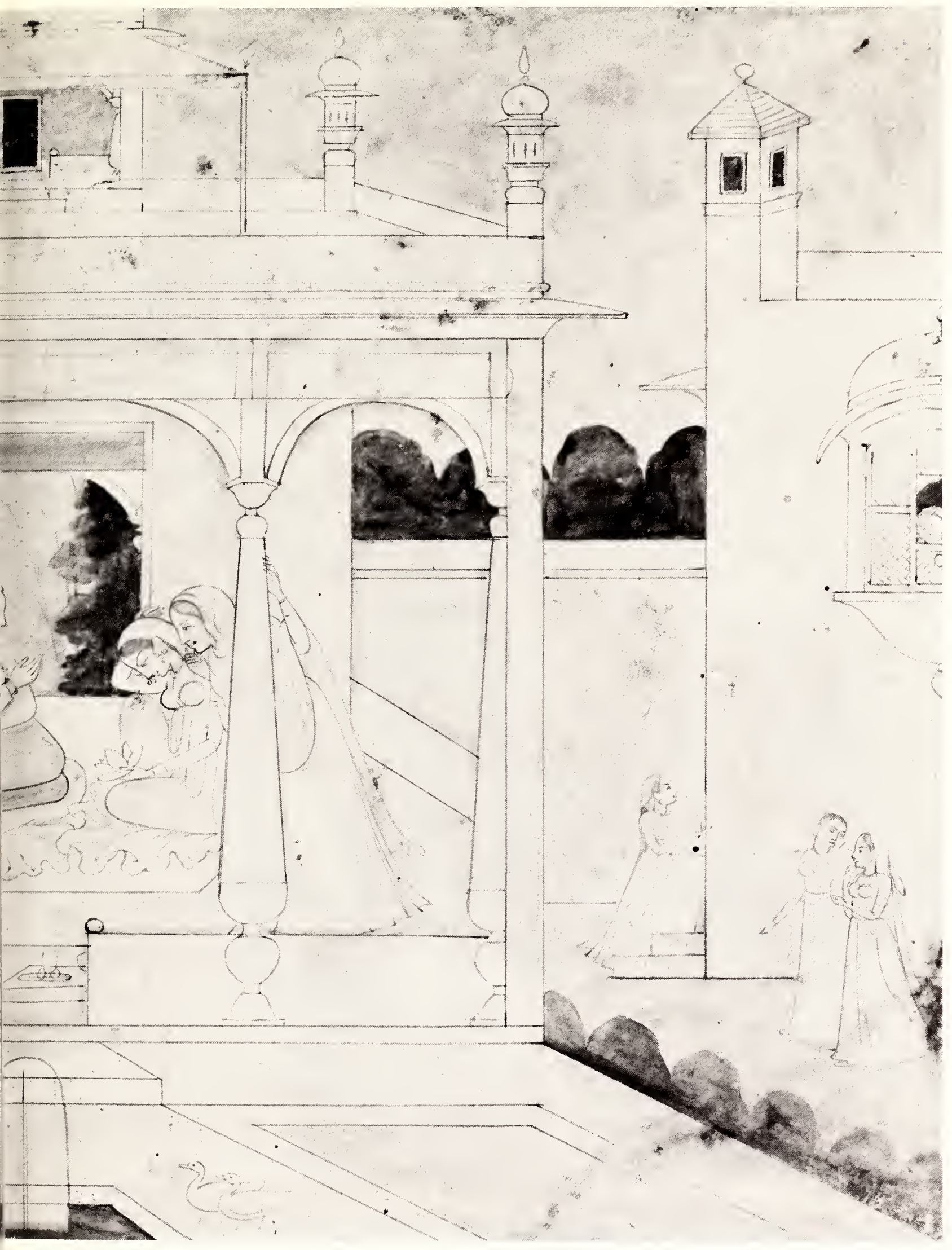



81. Damayanti with the Lotus rom the Romance of Nalis a

Indal, Rappur school, C.3.
1790.

Black line and silver over white ground on paper; rinred with
mauve, bluc, green, yellow' Page: $29.2 \times 39.8 \mathrm{~cm}$.

(1119/2 $\times 1511 / 16 \mathrm{in}$. (83) $\times 131 / 4$ in.)

After Nala and Damayanci setrle in blissful happinces, cheir unnavering devoction to $\mathrm{c}$ restr love thare exisss becween the bvers ate see within the tranquicy of thert palase, its secene atgures and theri lyric postures. in this episode Nala is jesting withh Damayannt and Kala. He has
fiven Damayanci a lous which hie considets mote valuable than was from her beloved. The couple are seasted in an arcaded pavition with three ducks walking around curcyard, conversing or carryin encer side. Rows of reecs borde the fountain and appeat behind

the cencet of the scene are $\mathrm{N}$ cuch. $N$. two cushions on his lap while conversing with Damayanti who ing the lorus in her hand as Kala with small botetcs, a spictoon for The setring was likely inspired by the palaces of Sansar Chand, the the luxurious structures of the Kangra Valley. These palaces wi arcaded pavilions placed aroun he archirectural tradditions estab
lished by the Mughals in the 16 and 1 thencentrics.

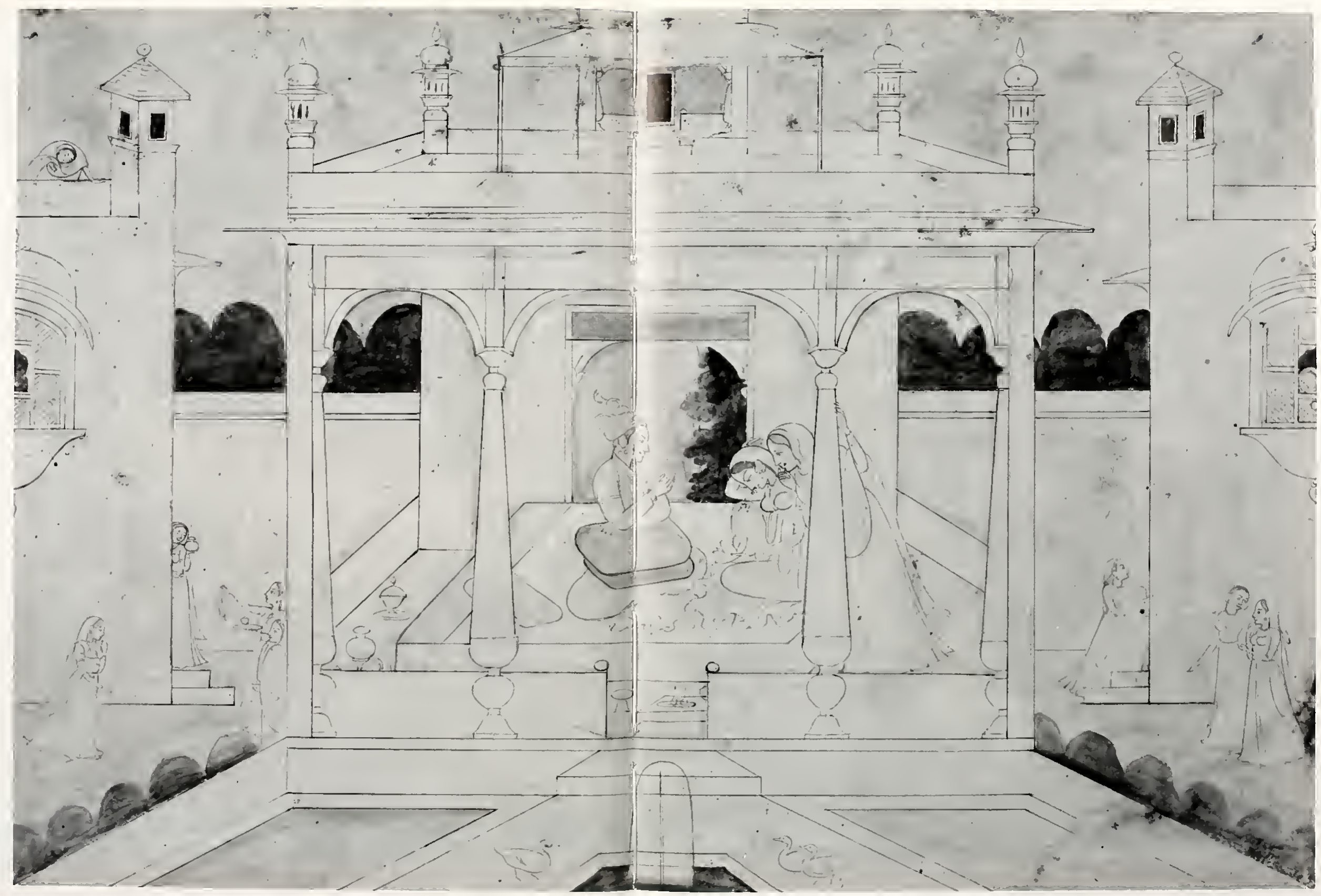


82. Lovers Watching Sunset From the Romance of Nala and Damayant

India, Rajput school, ca. $1790-1800$

Black tine and silver over white ground on paper; tinted with red, pink, green, yellow and black

Page: $29.2 \times 39.8 \mathrm{~cm}$. (111/2 $\times 15^{11 / 16 \mathrm{in})}$

Drawing: $22.2 \times 33.4 \mathrm{~cm}$. ( $83 \frac{1}{4} \times 131 / 8$ in.)

23.12

One of the most charming scenes in the Romance of Nala and Damayanti represents the lovers watching the sunset from their palace; Damayanti is mourning the fate of the cakrataka birds which separate from one another before darkness sets in. The couple is seated in an arcaded wing, leaning against a large pillow; they point to the birds which walk around the rocky shore across the water. Cushions, trays and bowls tie on the ground beside the figures

Outside the pavilion are two maidens seated at the edge of a pool, dipping their feet into the water Three other women appear in the doorway and arcades of the structure.

The background of the scenesky, trees and hills - is painted in pale tones; touches of color atso appear in the skin of the women, while the water is rendered in silver

The sentiment expressed by Damayanti-mourning the separation of lovers - symbolizes the theme of eternal love and devotion which permeates the poem.

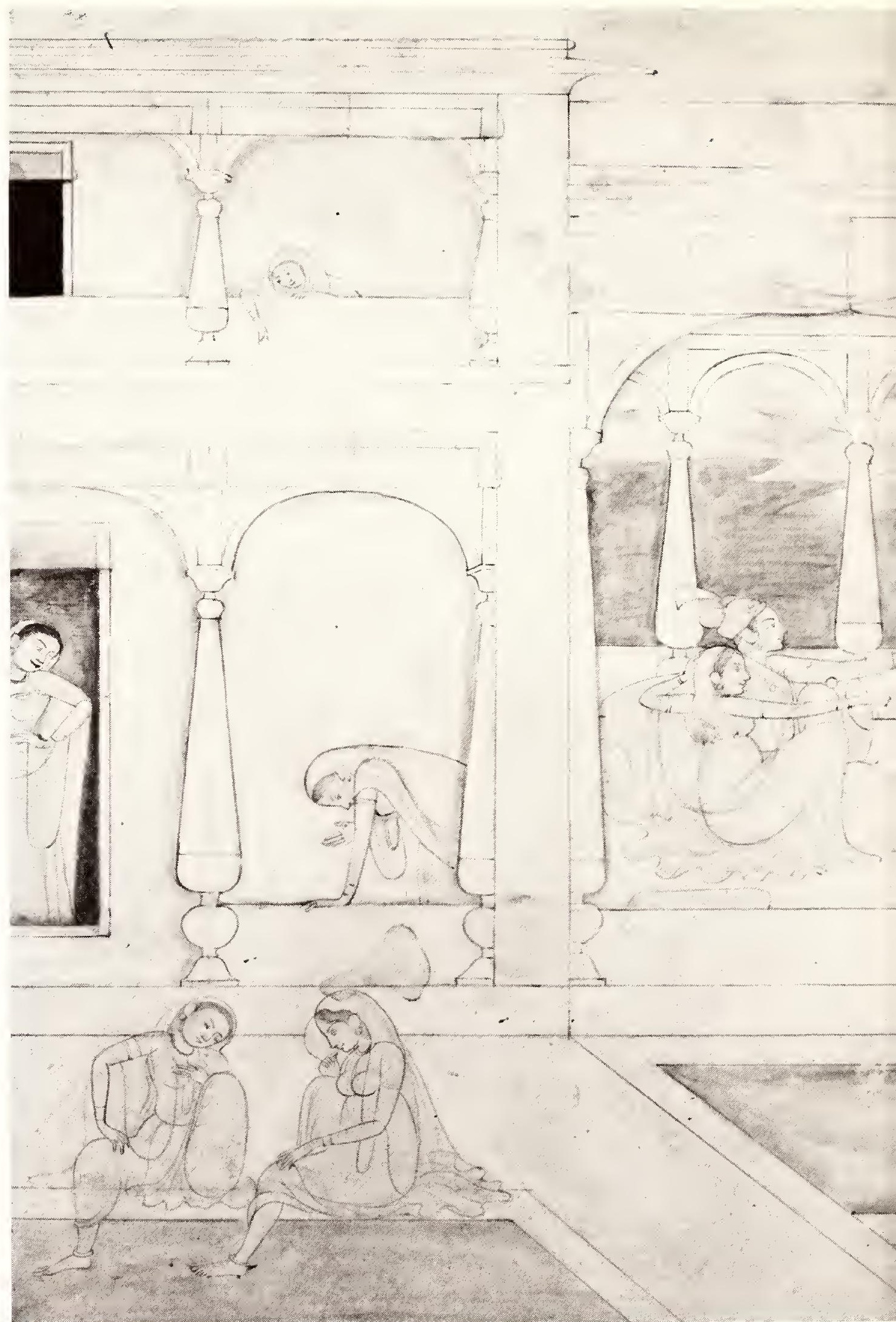




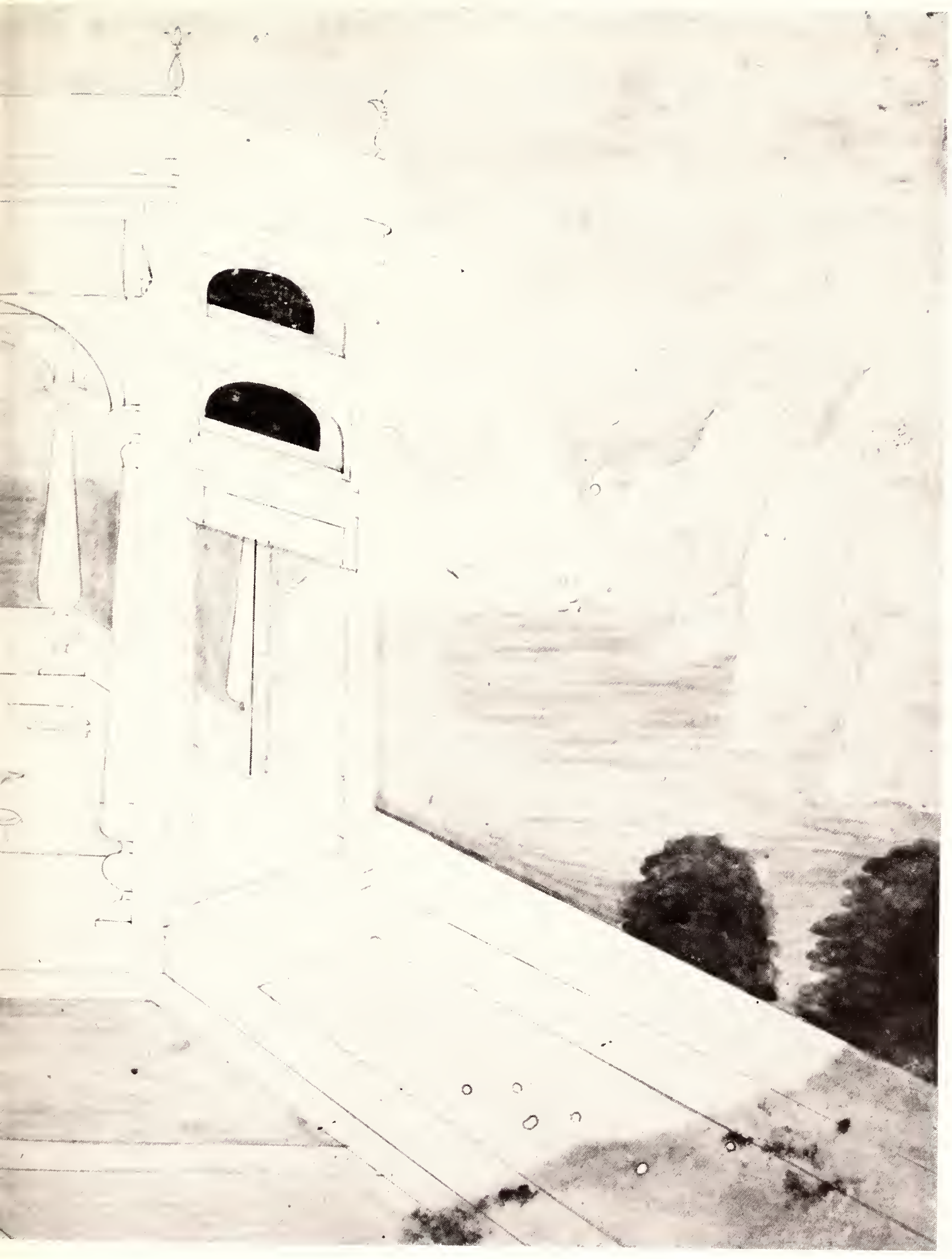



82. Lovers Warching Sunsect
From rhe Rumbunfe of Nullo and

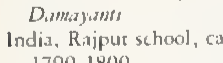

Black line and silver over white ground on paper; tinted with
red, pink, grecn, yellow and red, pink, grect,
black
$(1 \mathrm{l} 292 \times 39.8 \mathrm{~cm}$.

(111/2x $\times 1511 / 16$ in.) Deawing: $22.2 \times 33.40$
$\left(8^{34} \times 131 / 8 \mathrm{tn}\right)$

One of the most charming seet in rhe Romantice of Nala and warching the sunset from thei palace: Damayanti is moutnin the fate of the rakrataka birds before darknness sers in. The couple is seited in an arcaded wing, keaning againss a large piwalk around the rocky shore actoss the water. Cushoons, trays and bowls lic on the ground beside the figures.

Outside the pavilion are two

pool, dipping rheit feet into the water. Three orher women, appeat
in the doorway and atcades of the structu

The background of the scenepale rones; touches of color also appeat in rhe skin of the women, silver.

The sentiment expressed by Damayanti-mourning the sepwhich permeares rhe poe $m$.
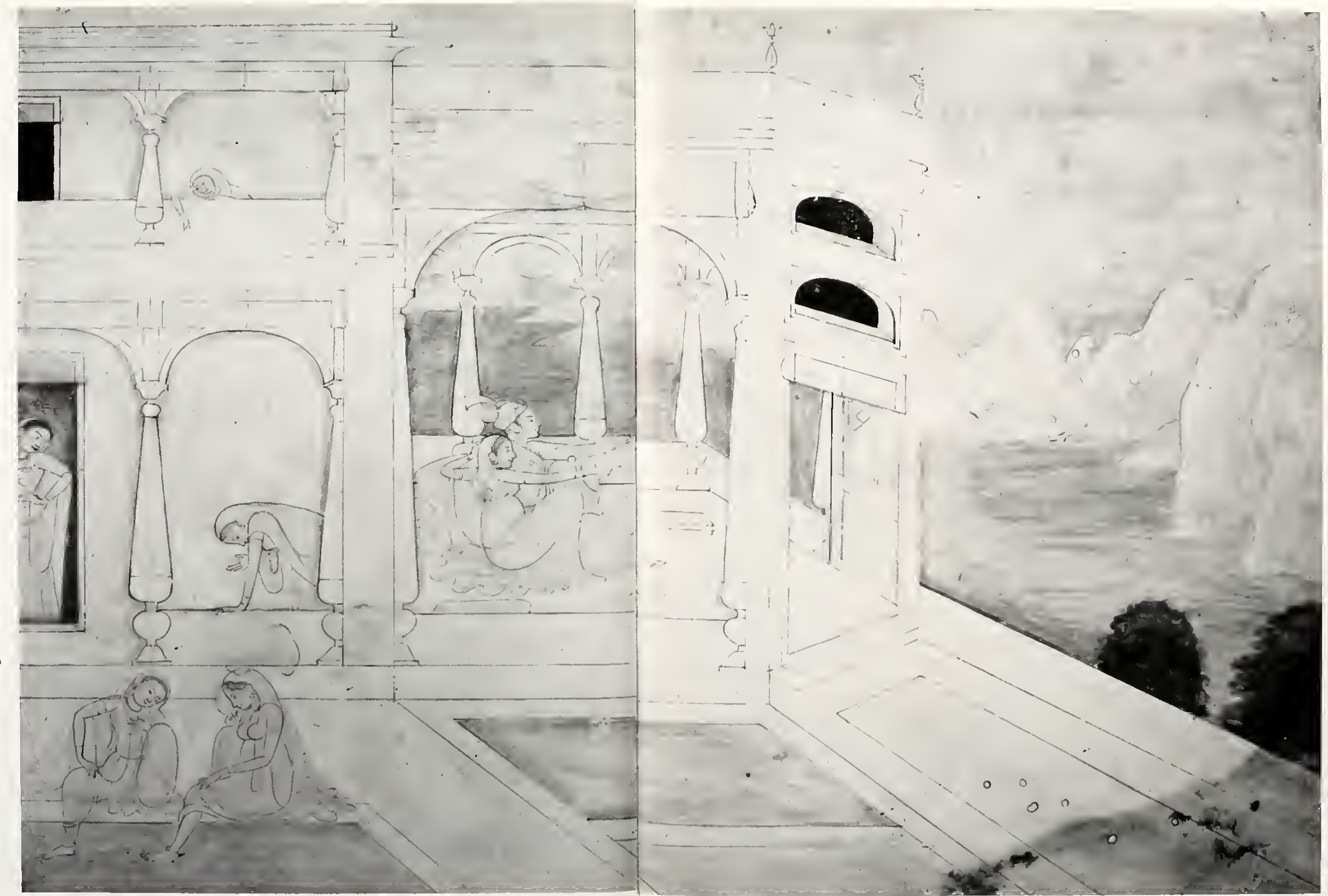



\section{Notes}

1. The manuscripts was first published in F. R. Martin, Miniatures from the Period of Timu in a Ms. of the Poems of Sultan Abmad Jalair, Vienna, 1926. In this publication Martin describes how he obtained rhe work in Istanbul. A thorough study of the Divan, its painter and date appears in Deborah E. Klimburg-Salter, "A Sufi Theme in Persian Painting: the Divan of Sultan Ahmad Galair in the Freer Gallery of Arr, Washingron, D.C.," Kunst des Orients, vol. XI, nos. 1-2 (1976-77), pp. 43-84.

2. Istanbul, Topkapi Palace Museum, H. 2153 and H. 2160. Anorher almost contemporary album is in Berlin, Staatsbibliothek, Diez A Fol. 70-73. The latter, with full references to the two Istanbul albums, is published in M. \$. Ipşiroğlu, Saray-Alben, Wiebaden, 1964

\section{M. S. Ipşiroğlu, Siyah Qulem, Graz, 1976}

4. Tabriz was occupied by the Kipchaks in 1385 , by the Timurids in 1386 and by the Karakoyunlus in 1387 and 1406; Baghdad was taken by Timur in 1393 and 1401 and by the Karakoyunlus in 1403.

5. Illustrated manuscripts executed in the courr of Sultan Ahmed are:

(a) Khamsa of Nizami (London, British Library, Or. 13297)

1386 and 1388 , Baghdad, copied by Mahmud ibn Muhammed

(b) Ajaib al-Makhlukat of al-Kazvini (Paris, Bibliothèque Nationale, suppl. pers. 332) 1392, Baghdad (?), copied by Ahmed of Herat

(c) Kalila va Dimna (Paris, Bibliothèque Nationale, suppl. pers. 913) 1392, Baghdad (?), copied by al-Hafiz Ibrahim

(d) Three Poems of Khvaju Kirmani (London, British Library, Add. 18113) 1396, Baghdad, copied by Mir Ali of Tabriz, painted by Junayd

(e) Kitab al-Bulban (Oxford, Bodleian Library, Or. 133)

Written in Arabic 1399, Baghdad (?), copied and painted by Abd al-Hasan ibn Ali ibn al-Hasan of Baghdad

(f) Divan of Sultan Ahmad (Washington, D.C., Freer Gallery of Art, 32.29-32.37) ca. 1400, Baghdad (?), copied by (att.): Mir Ali of Tabriz

(g) Khosrau va Shirin of Nizami (Washington, D.C., Freer Gallery of Art, 31.29-31.37) Before 1410 , Tabriz, copied by Ali ibn Hasan al-Sultani

See Also Dorothea Duda, "Die Buchmalerei der Galairden," part I, Der Islam, vol. 48 (1971), pp. 28-192; parr 11, ibid., vol. 49 (1972), pp. 153-220

6. When rhe Divan entered the Freer Gallery, the folios with the drawings were removed from the manuscriprs before it was paginated. In Martin's publication, it is menrioned that the illustrarions began on folio 17. Following the sequence of the reproductions in Martin's book, the accession numbers of the Freer Gallery and the text, we were able to derermine the order and location of the drawings within the manuscript

7. London, British Library, Add. 18113 (Charles Rieu, Catalogue of the Persian Manuscripts in the British Museum, London, 1966, vol. 11, pp. 620-622; Norah M. Titley, Miniatures from Persian Manuscripts, London, 1977, no. 251).

8. Abd al-Hayy was trained by Shams al-Din and taught the sultan to paint. After Timur conquered Baghdad, he took Abd al-Hayy together with other Jalairid artists to his court in Samarkand where the painter died. Abd al-Hayy is said to have become extremely religious toward the end of his life and destroyed his paintings. Several paintings and drawings, either signed by him or copied by a later Timurid artist named Muhammed al-Hayyam, appear in the Istanbul and Berlin albums (Klimburg-Salter, "A Sufi Theme"). Timur is also said to have taken Mir Ali of Tabriz to Samarkand (Rieu, Catalogue of Persian Manuscripts, p. 622).

9. Folios $311 \mathrm{~b}, 312 \mathrm{a}, 323 \mathrm{~b}, 328 \mathrm{~b}, 329 \mathrm{a}$ and $336 \mathrm{a}$. On two of these folios, a line or two of poetry appears on the top or bottom, although there are no marginal lines (fols. $31 \mathrm{lb}$ and 336a). There are also several other folios which are one-third empty (fols. 282b, $317 \mathrm{a}$ and 328a). Another completely empty folio without the original marginal lines is now entirely filled with the works of Sadi (fol. 282a).

10. Edwin Binney, 3rd, Turkish Minature Paintings and Manuscripts from the Collection of Edwin Binney, 3rd, New York and Los Angeles, 1973 , no. 29

11. Ipşiroğlu, Siyab Qalem, pl. 55. An almosr identical pair without shackles is reproduced in ibid., pl. 44.

12. Stuart Cary Welch, A King's Book of Kings: the Shab-nameb of Shab Tabmasp, New York, 1972, and Persian Painting: Five Royal Safavid Mamuscripts of the Sixteentb Century, New York, 1976.

13. For two of the manuscripts made in Herat, see ibid., pp. 55-61, and Peter J. Chelkowski and Priscilla P. Soucek, Mirror of the Imvisible World: Tales from the Khamseh of Nizami, New York, 1975. There is also rhe Divan of Hafiz, executed in Herat in 1523, owned by the Freer Gallery of Art (32.45-32.54).

14. Two of the albums compiled by Shah Tahmasp and Bahram Mirza are in Istanbul, Topkapi Palace Museum, H. 2161 and H. 2154 .
15. The manuscript (46.12) conrains 28 illustrations (S. C. Welch, Perian Painting. pp. 98-127).

16. For studies of the art of Isfahan under Shah Abbas, see lvan Stchoukine, Les Peintures des Manuscrits de Sbab Abbas Ier à la Fin des Safavir, Paris, 1964, and Renata Holod (ed.), Studies on Isfaban: Proceedings of the Isfahan Colloquizm, Iranian Studies, vol. V1I (1974), 2 vols. See also the following two publications by Anthony Welch: Shah Abbas and the Arts of Isfaban. New York, 1973, and Artists for the Shab: Late' Sixtenth-Century Patnting at the Imperial Court of Iran. New Haven and London, 1976.

17. Friedrich Sarre and Eugene Mirtwoch, Zeichnungen von Riza Abbasi. Munich, 1915, Abb. $4 b$

18. A. U. Pope (ed.), A Survey of Persian Art, London and New York, 1964-65, vol. V, p. 1883

19. Freer Gallery of Art, 33.7. Boston, Museum of Fine Arts, no. 14.368 (Ananda K Coomaraswamy, Les Miniatures Orientales de la Collection Goloubew au Museum of Fine Ants de Boston, Paris and Brussels, 1929, no. 50, pl. XXVII)

20. Boston, Museum of Fine Arts, nos 14.583-14.591 (ibid., no. 43, pl. XXIII).

21. The paintings owned by Boston, Museum of Fine Arts, are published in ibid., nos. 44-47, pls. XXII, XXIV-XXVI

22. The dared drawing is in Paris, Louvre, no. 7111 (LIslam dans les Collections Nationales, Edition de Musées Narionaux, Paris, 1977. no. 657). Muhammedi's drawings representing mystics and dervishes are in London, India Office Library, J.28.4 (B. W. Robinson, Persian Paintings in the India Office Library, London, 1976, no. 152, pl. V); Boston, Museum of Fine Arts, no. 14.649 (Coomaraswamy, Les Miniatures Orientales. no. 48 , pl. XXVI); Leningrad, Hermitage (F. R. Martin, The Miniature Painting and Painters of Persia, India and Trrkey, London, 1968, pl. 102); and in London, British Museum, formerly in a private collection (Thomas Arnold, Painting in Llam, New York, 1965, pl. XLVII).

23. The drawing with the knceling youth is in Paris, Louvre, no. K 3427 (L'Islam, no. 659); the dervish is in Dublin, Chester Bearty Library, no. 242 (Anthony Welch, "Painting and Parronage under Shah Abbas I," Studies on Isfaban, pp. 458-507, fig. 2). Two orher signed single-page paintings are in Isranbul, Topkapr Palace Museum, H. 2166, fol. 24b and H. 2156, fol. 45a (ibid., pp. 460-463, fig.

24. Also in Istanbul, Topkapi Palace Museum, H. 2166 , fol. 18a (ibid., fig. 3)

25. A drawing identical to no. 24 in the 
exhibition was published in P \& D Colnaghi \& Co., Ltd., Persian and Maghal Art, London, 1976 , no. 51.

26. Cl. Huart, Les Calligraphes et les Miniaturistes de L'Orient Musulman. Paris, 1908 , p. 229.

27. Philipp Walter Schultz, Die Perische-Islamisdo Miniaturmalerei, Leipzig, 1914, vol. 1, PP. 195 and 203

28. Robinson, Persian Painting, no. 894.

29. Stchoukine, Les Peintures de Mlanuscrits de Shab Ablas, p. 61. The drawing with the signature is in Boston, Museum of Fine Arts, no. 14.638 (Coomaraswamy, Les Miniatures Orientules, no. $87, \mathrm{pl}$. XLIX), and the attributed example is in London, British Library (Titley, Miniature from Persian Mamuscripts. no. 404-75)

30. Aka Riza was first identified with Riza-i Abbasi by Stchoukine in Les Peintures des Manuscrits de Shah Abbas. pp. 85-133.

31. Dublin, Chester Beatty Library, no. 277 (A. J. Arberry, B. W. Robinson, E. Blochet and J. V. S. Wilkinson, The Chester Beatty Library: a Catalogue of Persian Manuscripts and Miniatures, Dublin, 1962, vol. III, pp. 49-50).

32. The Kisas al-Anbiya is in Paris,

Bibliotheque Nationale, suppl. pers. 1313 (A Welch, "Painting and Patronage"); the Ditan was formerly in the Rothschild Collection (Colnaghi, Persian and Mughal Art, no. 43); and the Kbosrau va Shirin is in London, Victoria and Albert Museum (A. Welch, "Painting and Patronage").

33. Ibid., pp. 62-72. One of the Shabnames is in two volumes: vol. I, dated 1634 , is in Geneva, Prince Sadruddin Agha Khan Collection (A. Welch, Shat Ablas and the Arts of Isfahan, no. 57); vol. II, dated 1656, is in Dublin, Chester Beatty Library, no. 270 (ibid.). There is a second dispersed Shahmume. dated 1648 (ibid., no. 56; Colnaghi, Persian and Mugbal Art, no. 55). A third copy of the same work, dated 1617 , was illustrated by Muin ca. 1650-60 (Schultz, Die PersischeIslamische Miniaturmalerei, vol. 1I, pl. 169). The history of Shah Ismail, ca. 1650, is in London, British Library, Or. 3248 (Titley, Miniatures from Persian Manuscripts, no. 82). There are also several other Shabnumes attributed to Muin; for instance, the two copies in London, India Office Library (Robinson, Persian Paintings, nos. 1083 and 1152). For more than 30 works assigned to this artist, see Ernst Kühnel, "Der Maler

Muin," Puntbeon, vol. 29, no. 5 (1942), PP. 108-114.

34. Sarre and Mittwoch, Zeichnungen von Riza Abhasi.

35. Hoill, pls. 313, 24, 25 and 39.
36. The Turkish painting $(31 \times 19.7 \mathrm{~cm}$.$) is in$ the Binney Collection (Binney, Turkish Miniature Paintings, no. 22). For the copy made in India $(31.1 \times 18.6 \mathrm{~cm}$.), see Sotheby's Fine Oriental Miniatures, Manuscripts and Qajar Paintings, London, Tuesday, 4th April, 1978, no. 246.

37. The drawing was obtained from the Yildiz Palace by Sarre (Martin, Mimiature Paintings and Painters, p. 33).

\section{Ibid.}

39. Each of the five books of this work has a colophon with the name of the scribe and the date and place of execution. Shah Mahmud's signature appears in the colophon of the fifth book, the Subbat al-Abrar (46.12, fol. 46a), which states that Shal Mahmud al-Nishapuri finished the work on October 6, 1556, in Meshhed (C. S. Welch, Persian Painting. pp. 98-127).

40. Ibid. Titley, Miniatures from Persian Mcomuscripts. pp. 71-97. Shah Mahmud worked on this manuscript between 1539 and 1543.

41. V. Minorsky, Calligraphers and Painters: A Treatise by Qadi Abmad, Som of Mir-Munshi, Washington, D.C., 1959, pp. 135-138. The author of the treatise was Shah Mahmud's student and gives a detailed account of his master's life.

42. Ivan Stchoukine, Les Peintures des Manuscrits Safanis de 1502 à 1587, Paris, 1959, p. 43, and Les Peintures des Mamuscrits de Shab Abbas, p. 73 .

43. The figure here is drawn in the same pose but holds a book and pen. The size of this drawing is very close to that of the Freer example: $15.5 \times 8.3 \mathrm{~cm}$. (LIslam, no. 659).

44. S. C. Welch, A King's Book of Kings, fol 34lv on Pp. 165-167, and Persian Painting, pls. $39,41,46-48$

45. Richard Ettinghausen, "The Dance with Zoomorphic Masks and Other Forms of Entertainment Seen in 1slamic Art," Arabic and Islamic Studies in Honor of Hamilton A. R. Gibb. ed. George Makdisi, Leiden, 1965, pp. $211-224$

46. Martin, Mmiature Painting and Painters, pl. 102; Arnold, Painting in Islam, pl. XLVII The unsigned version, dating from the early 17 th century, is published in Richard Ettinghausen, "Stylistic Tendencies at the Time of Shah Abbas," Studies on Isfaban,

Pp. 593-628, fig. 6 .

47. The only reference to this calligrapher appears in Georges Marteau and Henri Vever, Mimatures Persanes, Paris, 1913, "Signatures des Calligraphers," no. 36.

48. His signature appears on an album page in
Boston, Museum of Fine Arts, no. 14.562 (Coomaraswamy, Les Miniatures Orientales. no. $37 \mathrm{a}$, pl. XIX)

49. The drawing was sold in 1976 (Colnaghi, Persian and Mugbal Art, no. 51).

50. For recent publications on Mughal drawings and paintings with full references to related sources, see Stuart Cary Welch, Indian Drauings and Painted Sketches, New York, 1976. and Imperial Mughal Painting. New York, 1978; Milo Cleveland Beach, The Grand Mogul: Imperial Painting in India 1600 1660. Williamstown, Mass., 1978.

51. Pramod Chandra, The Tuti-nama of the Cleveland Museum of Art, Graz, 1976.

52. The project was conceived in 14 volumes, each with 100 paintings. It is thought to have been begun in 1550 by Humayun and been completed in 1580 by Akbar. The majority of the existing illustrations are in Vienna and published in facsimile in Hamza-nama, vol. 1 , Graz, 1974 .

53. Four illustrated copies of the Baburname were made in the $1590 \mathrm{~s}$, all of which are incomplete and dispersed (Ellen Stevens Smart, Paintings from the Baburnama: a Study of Sixteenth Century Mughal Historical Manuscript

Illustrations, University of London, 1977, doctoral dissertation). Three illustrated copies of the Akbarname were made during the lifetime of the subject (Deborah Brown Levine, The Victoriu and Albert Museum Akbur-nama: a Study in History, Myth and Image, University of Michigan, 1974, doctoral dissertation published by University Microfilms, Ann Arbor, Michigan)

54. For the marginal drawings of this volume signed by Aka Riza and Daulat, see Yedda A. Godard, "Les Marges de Murakka Gulshan," Athar-e Iran, vol. I (1936), pp. 11-33

55. Ernst Kühnel and Hermann Goetz, Indische Buchmalereien aus dem Jahangir Album des Staatsbibliothek zu Berlin, Berlin, 1924.

56. Milo Cleveland Beach, "The Gulshan Album and 1ts European Sources," Bulletin of the Aluseum of Fine Arts, Boston, vol. LXIII, no. 332 (1965), pp. 63-90.

57. Godard, "Les Marges du Murakka Gulshan," figs. 1-8.

58. The Freer Gallery of Art owns three paintings depicting Jahangir signed by this artist: $46.28,48.28$ (dated 1623) and 45.9 (Richard Ettinghausen, Paintings of the Sultoms and Emperors of India in American Collections, New Delhi, 1961, pls. 11 and 12)

59. Huart, Les Calligraphes, p. 225. The name of this artist appears both in the Tehran and Berlin Jahangir albums. It is also found in the colophon of the Khamsa of Nizami, dated 1509 , 
in Dublin, Chester Beatty Library, no. 182 (Stchoukine, Les Peintures des Manuscrits Safavis, no. 47); on an album leaf in London, India Office Library, J. 28.5 (Robinson, Persian Paintings, no. 222); and on a folio from an Ottoman album in the Freer Gallery of Art, 33.6 (Esin Atil, Turkish Art of the Ottoman Period, Washington, D.C., 1973, no. 5). The style of Ali is almost identical to that of the celebrated Mir Ali of Herat and both calligraphers often use "al-Katib" and/or "al-Sultani" after their name. It has been suggested that the two names belong to the same artist.

60. Minorsky, Calligraphers and Painters, pp. 126-131. Many of his works are included in the Tehran and Berlin Jahangir albums. The Freer Gallery of Art owns several other Mughal album leaves which contain Mir Ali's signed examples: $07.258,39.49,39.50$ and 48.28 (dated 1533-34).

61. For the works of Aka Riza, see Godard, "Les Marges du Murakka Gulshan," figs. 1-8. Govardhan's drawing is reproduced in Kühnel and Goetz, Indische Buchmalereien, pl. 38.

62. For a detailed study of the karg, or rhinoceros, see Richard Ettinghausen, Studies in Muslim Iconography: I. The Unicom,

Washington, D.C., 1950.

63. The most comprehensive study of this school is in W. G. Archer, Indian Paintings from the Punjab Hills, London, 1973, 2 vols.

64. lbid., vol. I, pp. 244-310; vol. II, pp. 194-234.

65. This set is discussed in Alvan C. Eastman, The Nala-Damayanti Drauings. Boston, 1959. 

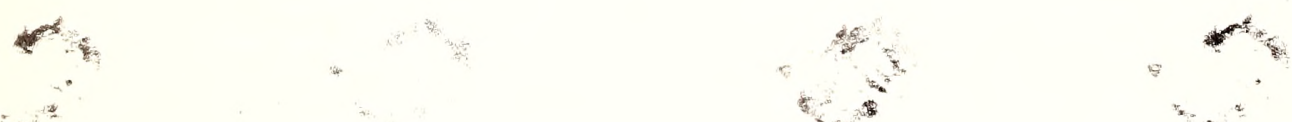

की 6

+.... 


\section{Appendix}

Name of calligrapher

Ali

Hasan Shamlu

Mir Ali (of Herat)

Mir Ali (of Tabriz)

Muhammed Huseyin al-Tabrizi

Muhammed Riza

Shah Mahmud

Cat. no.

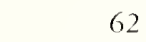

$63,64,65$

$1-7$

22

$15 \mathrm{~A}$

12

Name of painter

Abd al-Samad

Abu 'I-Hasan

Mirza Muhammed al-Huseyni

Muhammedi

Muhammed Muhsin

Muin Musavvir

Murad

Riza

Sheykh Muhammed

Dated drawings

\section{8}

1613

1616

1619

1633

1638

1639

1641

1642

1643

1649

1672
Accession Numbers in Numerical Order

Acc. no. Cat. no.

07.2

07.155

07.157

07.161

07.204

07.211

07.213

07.256

07.607

07.618

12.99

23.10

23. 11

23.12

23.13

28. 10

29.3

29.76

29.79

30.85

32.9

32.30

32.31

32.32

32.33

32.34

32.35

32.37

37.8

37.21

37.23

37.25

38.14

40. 18

45.29

46.15

46.27

47.22

47.23

50.1

50.2

52.2

53.12
Acc. no. Cat. no.

53.13

53.14

53.16

53.17

53.22

53.23

53.24

53.25

53.26

53.27

53.28

53.29

53.30

53.31

53.32

53.33

53.34

53.35

53.36

53.37

53.39

53.40

53.41

53.42

53.43

53.44

53.45

53.46

53.47

53.48

53.49

53.57

53.58

54.24

54.27

54.28

54.32

54.116

56.12

63.4

66.13

67.7

68.11
53 



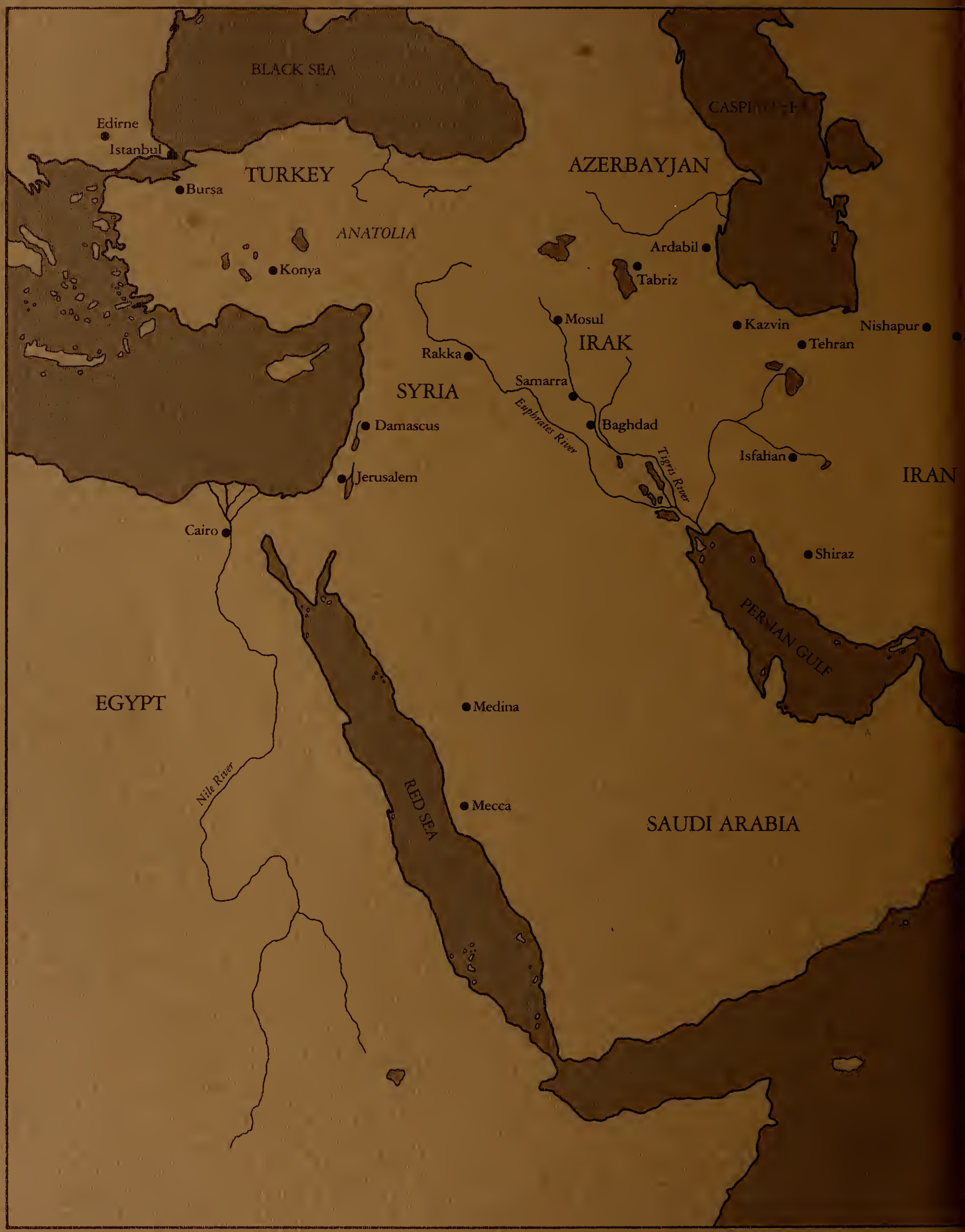





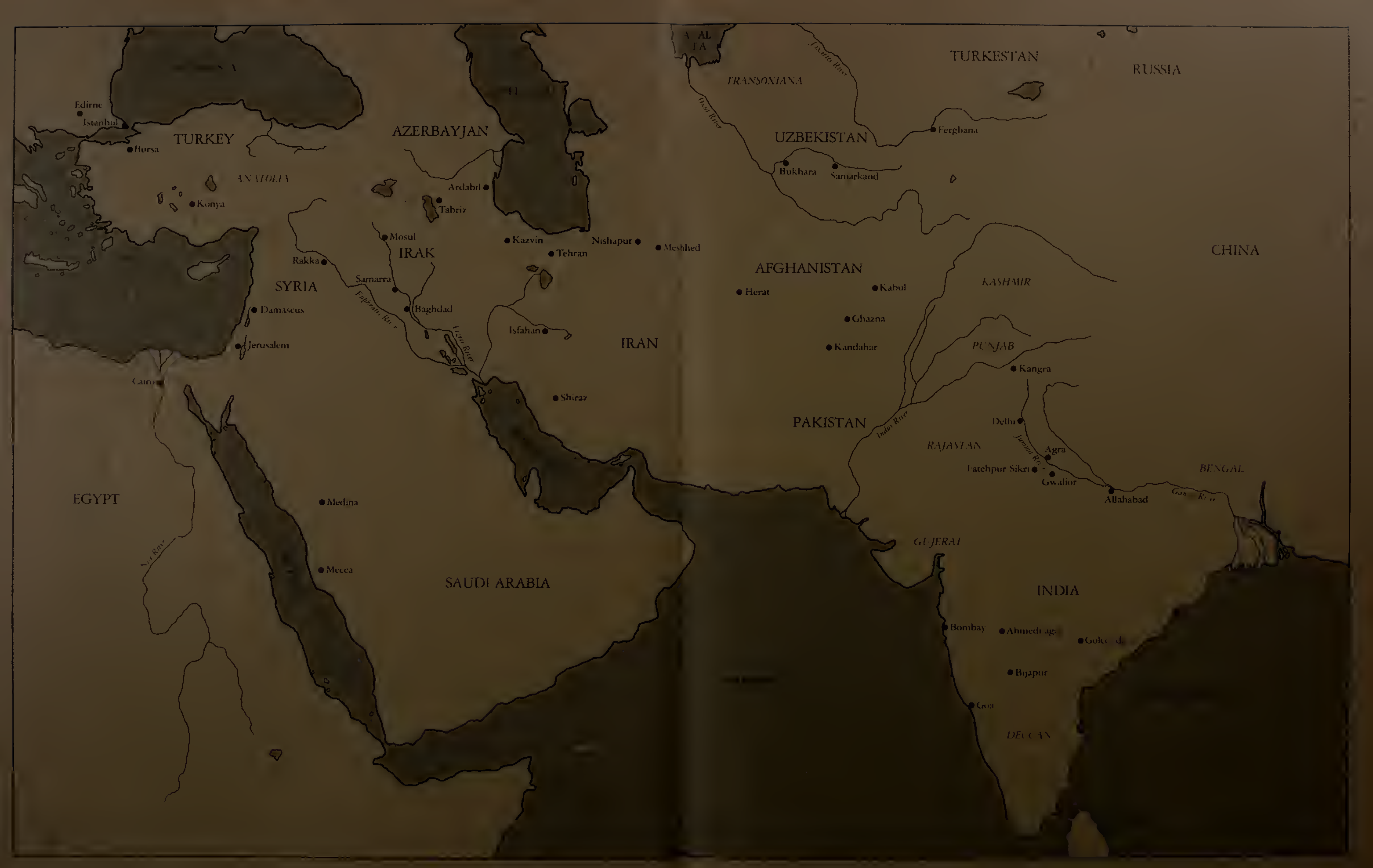


